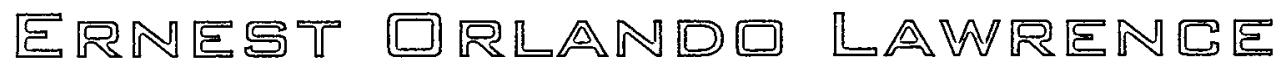

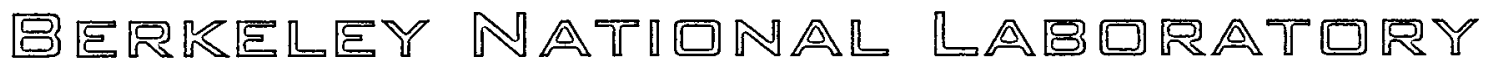

\title{
Site Environmental Report for 1998 Volume I
}

Environment, Health, and Safety Division

September 1999

\author{
RECRET \\ OCT 4 4 499 \\ $0 \%$
}




\section{DISCLAIMER}

This document was prepared as an account of work sponsored by the United States Government. While this document is believed to contain correct information, neither the United States Government nor any agency thereof, nor The Regents of the University of California, nor any of their employees, makes any warranty, express or implied, or assumes any legal responsibility for the accuracy, completeness, or usefulness of any information, apparatus, product, or process disclosed, or represents that its use would not infringe privately owned rights. Reference herein to any specific commercial product, process, or service by its trade name, trademark, manufacturer, or otherwise, does not necessarily constitute or imply its endorsement, recommendation, or favoring by the United States Government or any agency thereof, or The Regents of the University of California. The views and opinions of authors expressed herein do not necessarily state or reflect those of the United States Government or any agency thereof, or The Regents of the University of California. 


\section{DISCLAIMER}

\section{Portions of this document may be illegible in electronic image products. Images are produced from the best available original document.}




\title{
Site Environmental Report for 1998
}

\author{
Volume I
}

September 1999

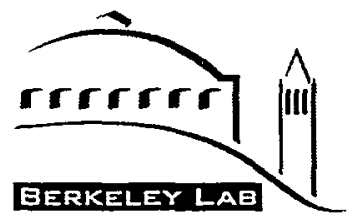

ERNEST DRLANDI LAWRENCE BERKELEY NATIONAL LABIRATIRY

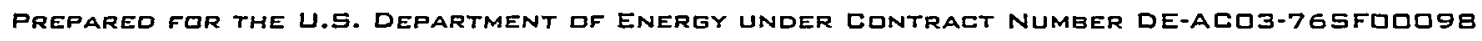





\section{Volume I}

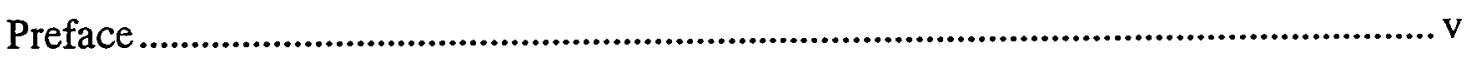

1 Executive Summary ................................................................... 1-1

2 Introduction ............................................................................ 2-1

3 Environmental Program Summary ................................................................... $3-1$

4 Air Quality ................................................................................ 4-1

5 Surface Water .......................................................................... 5-1

6 Groundwater ............................................................................. 6-1

7 Sanitary Sewer .............................................................................................. 7-1

8 Soil and Sediment ..................................................................... 8-1

9 Vegetation and Foodstuffs............................................................. 9-1

10 Radiological Dose Assessment ....................................................... 10-1

11 Quality Assurance ...........................................................................11-1

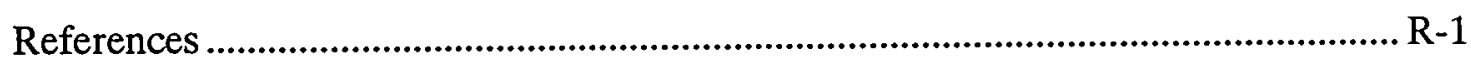

Acronyms and Abbreviations ……….............................................................AA-1

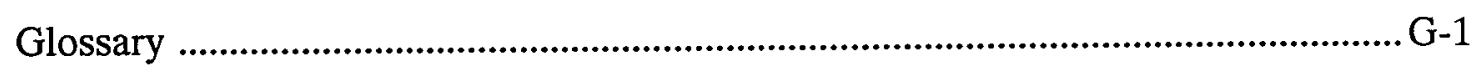

Volume I Distribution List .............................................................................. D-1 


\section{Volume II}

Appendix Monitoring Data ......................................................................A-1

Stack Air .......................................................................

Ambient Air .....................................................................39

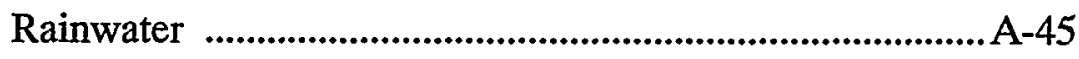

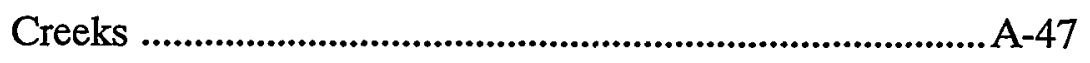

Creek Baseline Study .......................................................... A-71

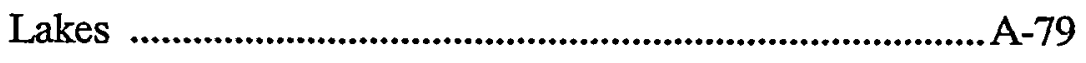

Hydraugers ................................................................................ A-81

Stormwater ............................................................................... A-83

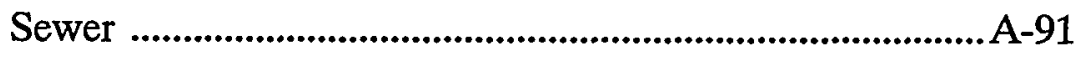

Fixed Treatment Units ..........................................................A-107

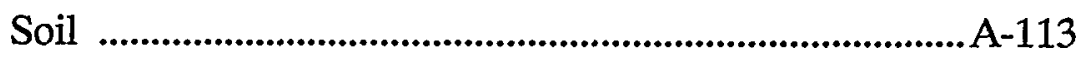

Sediment ….............................................................................. A-117

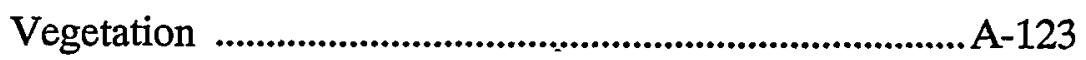




\section{Preface}

Each year, Ernest Orlando Lawrence Berkeley National Laboratory prepares an integrated report on its environmental programs to satisfy the requirements of U.S. Department of Energy Order 231.1. The Site Environmental Report for 1998 is intended to summarize Berkeley Lab's compliance with environmental standards and requirements, characterize environmental management efforts through surveillance and monitoring activities, and highlight significant programs and efforts for calendar year 1998.

The report is separated into two volumes. Volume I contains a general overview of the Laboratory, the status of environmental programs, and summary results from surveillance and monitoring activities. Each chapter in volume I begins with an outline of the sections that follow, including any tables or figures found in the chapter. Readers should use section numbers (e.g., \$1.5) as navigational tools to find topics of interest in either the printed or the electronic version of the report. Volume II contains the individual data results from monitoring programs. Although a printed version of volume II is not part of the report's initial distribution, it is available on request (see below).

The report follows the Laboratory's policy of using the International System of Units (SI) or metric system of measurements. Whenever possible, results are also reported using the more conventional inch-pound system of measurements because this system is referenced by some current regulatory standards and may be more familiar to some readers. The tables included at the end of the glossary are intended to help readers understand the various prefixes used with SI units of measurement and convert these units from one system to the other.

This report was prepared under the direction of Michael Ruggieri of the Environmental Protection Group. Iraj Javandel, Ginny Lackner, Michael Ruggieri, Patrick Thorson, and Henry Tran were the primary authors of the report. Other key contributors of programmatic information include David Baskin, Robert Fox, Lori Fries, Rich McClure, Nancy Rothermich, Brian Smith, Mark Turner, and Steve Wyrick.

This report was prepared through Berkeley Lab's Technical \& Electronic Information Department. Maryann Aberg managed technical editing, design, and production of the report, assisted by Jean Wolslegel (composition), Flavio Robles, Jr., and Denise Allen (illustration), and Erik Richman (Web services).

Copies of the report are available from several resources: the Office of Scientific and Technical Information and the National Technical Information Service (see inside front cover), the Berkeley Lab Web site (http://www.lbl.gov; choose "Site Index"), or Michael Ruggieri (telephone: (510) 486-5440; e-mail: mrruggieri@lbl.gov). 


$\frac{1}{\text { Executive Summary }}$

I. INTRODUCTION \$1.1

II. ENVIRONMENTAL PERMITS, INSPECTIONS, INCIDENT TRACKING, AND PERFORMANCE EVALUATION $\$ 1.2$
A. Permits $\$ 1.3$
B. Inspections $\$ 1.4$
C. Incident Tracking \$1.5
D. Performance Evaluation \$1.6

III. ENVIRONMENTAL MONITORING \$1.7
A. Radiological Monitoring $\$ 1.8$
Figure 1-1: Typical Radiation Doses Received by Public, Including Maximum Contribution from Berkeley Lab

B. Nonradiological Monitoring $\$ \mathbf{\$ 1 . 9}$

\section{$\$ 1.1 \quad$ I. INTRODUCTION}

The mission of Ernest Orlando Lawrence Berkeley National Laboratory (Berkeley Lab) is to continue the long tradition of outstanding research that has made it a premier national and international multiprogram laboratory. Laboratory activities are planned and conducted with full regard to protecting the public and the environment and complying with appropriate environmental laws and regulations. Both radiological and nonradiological activities are thoroughly monitored to assess their potential impact on the environment.

Published annually, this Site Environmental Report covers activities for calendar year 1998. Volume I summarizes environmental protection performance and environmental monitoring activities. Volume II contains all original analytical data used to summarize the environmental monitoring results in the first volume. Volume II is available on request (for details, see preface).

Data are presented in the report using the International System of Units measuring system, more commonly referred to as the metric system. For the convenience of readers, both volumes of this report can be accessed on the Web using the index found on the 
Berkeley Lab home page, which is located at http://www.lbl.gov. Readers are encouraged to comment on this report by completing (a) the survey card included with the distributed hard copy or (b) the survey form in the Web version of this report. The format and content of this report satisfy the requirements of United States Department of Energy (DOE) Order 231.1, Environment, Safety and Health Reporting, ${ }^{1}$ and the operating contract between the University of California (UC) and DOE. ${ }^{2}$

\section{$\$ 1.2$ II. ENVIRONMENTAL PERMITS, INSPECTIONS, INCIDENT TRACKING, AND PERFORMANCE EVALUATION}

Berkeley Lab's environmental program involves permits, inspections, incident tracking, performance evaluation, and environmental monitoring. The first four items are discussed in §§1.3-1.6. Environmental monitoring is briefly discussed in §§1.7-1.9.

\section{$\$ 1.3 \quad$ A. Permits}

At the end of 1998, Berkeley Lab managed 21 operations that were subject to environmental operating permits from various regulatory agencies:

- Air emission sources (6);

- Hazardous waste handling and treatment operations (2);

- Stormwater discharges (1);

- Underground storage tanks (8); and

- Wastewater discharges (4).

For further discussion of these permits, see chapter 3.

\section{$\$ 1.4$ B. Inspections}

Twenty-nine inspections of Berkeley Lab's environmental programs occurred during 1998, with five reports of violations issued from these inspections by regulatory agencies. Two violations pertained to medical waste handling. Two violations were related to Building 77 sewer discharge levels of chromium that exceeded permit limits. One violation was related to waste storage in a generator area. All five violations have been corrected. For further discussion of these violations, see §§3.17, 3.19, and 3.25.

\section{$\$ 1.5$ C. Incident Tracking}

Berkeley Lab filed four reports with DOE for minor environmental incidents in 1998 that were reportable to DOE under its occurrence-reporting program. For further discussion of these incidents, see $\S \S 3.5,3.7,3.17$, and 3.25. 


\section{$\$ 1.6$ D. Performance Evaluation}

The operating contract between $\mathrm{UC}$ and DOE requires Berkeley Lab to perform an assessment of its environmental program each year, using measures developed jointly by Berkeley Lab, UC, and DOE. ${ }^{3}$ There are four environmental program measures:

1. Radiation Protection of the Public and the Environment;

2. Tracking Environmental Incidents;

3. Waste Reduction and Recycling; and

4. Waste Minimization, Pollution Prevention, and Protection of the Environment.

From possible ratings of "outstanding," "excellent," "good," and "no ranking," Berkeley Lab achieved a rating of "outstanding" on the third measure, "excellent" on the first and second measures, and "good" on the fourth measure.

For additional information on the performance review program, see $\$ \S 3.29-3.34$.

\section{$\$ 1.7$ III. ENVIRONMENTAL MONITORING}

Berkeley Lab's environmental monitoring program serves several purposes:

- To demonstrate that Laboratory activities operate within regulatory and DOE requirements;

- To provide a historical record of measured changes in the environment; and

- To support environmental management decisions.

Both radiological and nonradiological contaminants are monitored in the local environment. ${ }^{4}$ Below are brief summaries of environmental measurements from 1998.

\section{$\$ 1.8 \quad$ A. Radiological Monitoring}

A significant portion of the environmental monitoring program measures radiological impacts from Laboratory activities. The Laboratory monitors two types of radiation: (1) penetrating radiation from sources such as accelerators and (2) dispersible radionuclides from a wide range of Laboratory research activities. Specially designed shielding blocks are in place to reduce the release of penetrating radiation into the environment, and capture systems are used to retain most dispersible radionuclides so that they are not released into the atmosphere.

The primary radiological compliance standards affecting the Laboratory are based on the maximum potential dose that a member of the public would receive from both direct penetrating radiation and dispersible radionuclides from the site. For 1998, this maximum annual dose to an individual was determined to be 0.007 millisieverts $(\mathrm{mSv})$ ( 0.7 millirem (mrem)) or only about $0.7 \%$ of the applicable DOE radiological standard of $1 \mathrm{mSv} / \mathrm{yr}(100 \mathrm{mrem} / \mathrm{yr}){ }^{5}$ This estimate is also about $0.3 \%$ of the dominant source of radiation in the Bay Area, which is naturally occurring background radiation. The estimate for background radiation in the Bay Area is $2.6 \mathrm{mSv} / \mathrm{yr}(260 \mathrm{mrem} / \mathrm{yr}){ }^{6}$ Figure 1-1 shows that Berkeley Lab ranks as a minor contributor to the dose received by a typical member of the public from all contributing sources of radiation (i.e., natural terrestrial background, medical, and consumer products). 


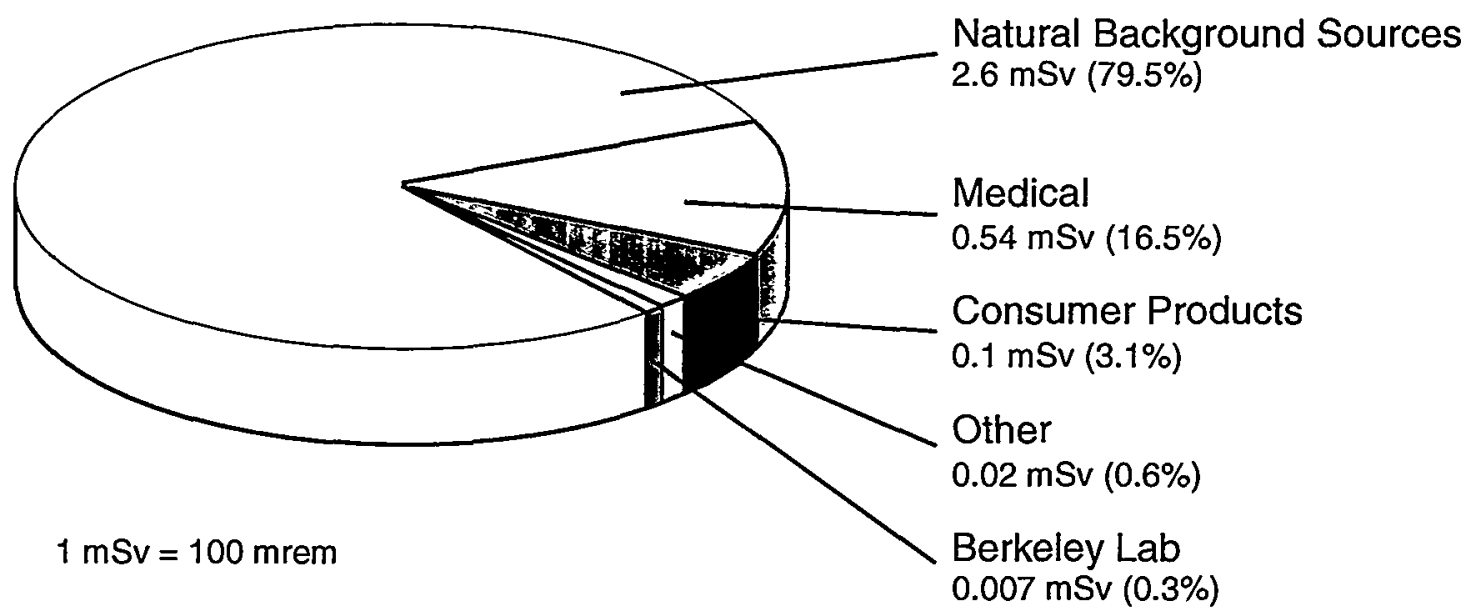

Figure 1-1 Typical Radiation Doses Received by Public, Including Maximum Contribution from Berkeley Lab

Berkeley Lab also estimates the cumulative dose impact (collective population dose) from its penetrating and dispersible radiological activities to the entire population found within an 80-kilometer (50-mile) radius of the Laboratory. This measure is the sum of all individual doses (i.e., ranging from a maximum of $0.007 \mathrm{mSv}$ near the site boundary to a minimum of 0 at an 80-kilometer distance) within the specified region. The collective population dose for 1998 was estimated at $2.56 \times 10^{-2}$ person-Sv (2.56 person-rem) or about two ten-thousandth of one percent of the dose that the population within this region received from background radiation. No regulatory standard exists for this measure. For further discussion of the estimated dose impacts to the neighboring community from both direct and dispersible radiation, see chapter 10.

Dispersible radionuclide sources are regulated by the United States Environmental Protection Agency (US/EPA). The US/EPA has set $0.1 \mathrm{mSv} / \mathrm{yr}(10 \mathrm{mrem} / \mathrm{yr})^{7}$ as the maximum allowable dose to the public from all exposure pathways (e.g., inhalation, ingestion) resulting from airborne releases of radionuclides. The estimated maximum potential dose from all airborne radionuclides released from the site in 1998 was $0.003 \mathrm{mSv}(0.3 \mathrm{mrem})$, with tritium accounting for over $90 \%$ of that amount. This dose is about $3 \%$ of the US/EPA limit and about $40 \%$ of Berkeley Lab's total maximum dose to the public.

\section{$\$ 1.9 \quad$ B. Nonradiological Monitoring}

Berkeley Lab's nonradiological monitoring program focuses primarily on water, soil, and sediment.

In compliance with the four wastewater discharge permits ${ }^{8}$ issued to the Laboratory by the East Bay Municipal Utility District, Berkeley Lab samples for metals, chlorinated hydrocarbons, and other specified parameters in sanitary sewer discharges. In 1998, two wastewater discharge samples were above permit limits for chromium. See chapter 3. For details on the wastewater discharge sampling program, see chapter 7. 
Stormwater discharges at Berkeley Lab are regulated under a general permit ${ }^{9}$ issued by the State Water Resources Control Board. Stormwater discharges are treated differently from wastewater in that no specific discharge limits are cited in the permit. References in the permit to the Water Quality Control Plan (Basin Plan) ${ }^{10}$ for the San Francisco Bay Basin are intended as guidelines rather than measures of compliance for stormwater discharges. Berkeley Lab analyzes stormwater samples for a wide set of potential contaminants, including $\mathrm{pH}$, oil and grease, total suspended solids, and metals. All results for the year were below or near sample detection limits. For the results from stormwater sampling efforts throughout the year (along with the results from the sampling of rainwater, creeks, lakes, and hydraugers), see chapter 5.

Extensive groundwater monitoring has been conducted by Berkeley Lab since the early 1990s, and eight groundwater plumes have been identified. These plumes are all on site. The groundwater in the vicinity of the Laboratory is not used for public drinking water. There are four types of plume contaminants:

- Volatile organic compounds (four plumes);

- Fuel (two plumes);

- Freon (one plume); and

- Tritium (one plume).

The Laboratory has nearly completed characterizing these plumes and is developing long-term strategies to address the contamination. Until the Laboratory can implement these strategies, it has initiated several interim corrective action measures to remediate the contaminated media or prevent movement of contamination. Concentrations of contaminants are reported to agencies quarterly, along with other program developments and planned activities. For further information, see chapter 6.

The current soil and sediment monitoring program analyzes samples for metals, $\mathrm{pH}$, and organic compounds at locations that complement sampling in other media such as air and surface water. Similar to results reported for other programs, most samples were below or near analytical detection limits. The exception was for oil and grease samples collected near roadway or parking lots. The levels of oil and grease measured at Berkeley Lab are not uncommon for an urban setting. For more on Berkeley Lab's impact on soil and sediment, see chapter 8 . 


\section{Introduction}

I. HISTORY \$2.1

II. LABORATORY
A. Location $\$ 2.2$

Figure 2-1: San Francisco Bay Area Map

Figure 2-2: Vicinity Map

Figure 2-3: Adjacent Land Use

Figure 2-4: Space Distribution

B. Population and Space Distribution $\$ \mathbf{\$ 2 . 3}$

C. Water Supply $\$ 2.4$

III. ENVIRONMENTAL SETTING
A. Meteorology \$2.5

Figure 2-5: Temperature Summary by Month

Figure 2-6: Annual Wind Patterns

Figure 2-7: Precipitation Summary by Month
B. Vegetation \$2.6

Figure 2-8: Vegetation Types

C. Wildlife $\$ 2.7$

D. Geology $\$ 2.8$

E. Hydrogeology $\$ 2.9$

\section{$\$ 2.1$ I. HISTORY}

Berkeley Lab was founded by Ernest O. Lawrence in 1931 on the Berkeley campus of the University of California. Winner of the 1939 Nobel Prize in Physics for his invention of the cyclotron (particle accelerator), Lawrence is generally credited with the modern concept of interdisciplinary science, in which scientists, engineers, and technicians from different fields work together on complex scientific projects directed at national needs and programs. Lawrence's pioneering work established a great tradition of scientific 
inquiry and discovery at the Laboratory, leading to the awarding of Nobel Prizes to eight other Berkeley Lab scientists.

The Laboratory supports work in such diverse fields as fundamental physics, energy conservation technology, materials science, structural biology, medical imaging, and advanced battery technologies. Through its fundamental research in these fields, Berkeley Lab has achieved international recognition for its leadership and made numerous contributions to national programs. Its research embraces the DOE mission concepts of exploring the complexity of energy and matter, advancing the science for abundant clean energy, understanding energy impacts on our living planet, and providing extraordinary tools for multidisciplinary research.

Since its beginning, Berkeley Lab has been managed by the University of California. Numerous Berkeley Lab scientists are faculty members on the campuses of either UC Berkeley or UC San Francisco. They and other Berkeley Lab researchers guide the work of graduate students pursuing their advanced degrees through research at the Laboratory. High school students and teachers, as well as college and graduate students, also participate in many Berkeley Lab programs designed to enhance science education both locally and nationally.

\section{LABORATORY}

\section{$\$ 2.2$ A. Location}

Berkeley Lab is located 8 kilometers (5 miles) east of San Francisco Bay (see Figure 2-1) on 479 hectares (1,183 acres) of land owned by the University of California. The Laboratory's 80 -hectare (200-acre) main site is under long-term lease to DOE.

The main site lies in the hills above the UC Berkeley campus, on the ridges and draws of Blackberry Canyon (which forms the central part of the site) and Strawberry Canyon (which forms the southern boundary), with elevations ranging from 200 to 330 meters (650 to 1,000 feet) above sea level. The western portion of the site is in Berkeley, with the eastern portion in Oakland. See Figure 2-2. The population of Berkeley is estimated at 108,000 and Oakland at 387,000.

Adjacent land use consists of residential, institutional, and recreation areas. See Figure 2-3. The area to the south and east, which is University land, is maintained largely in a natural state and includes UC Berkeley's recreational facilities and Botanical Garden. Northeast of the Laboratory are the University's Lawrence Hall of Science, Space Sciences Institute, and Mathematical Sciences Research Institute. Berkeley Lab is bordered on the north by single-family homes and on the west by the UC Berkeley campus as well as multiunit dwellings, student residence halls, and private homes. The area to the west of Berkeley Lab is highly urbanized.

\section{\$2.3 B. Population and Space Distribution}

Almost 3,000 scientists and support personnel work at Berkeley Lab's main site. In addition, the Laboratory typically hosts 1,900 guests each year, who use its unique scientific facilities for varying lengths of time. Approximately 750 of these guests work on site at any one time. Berkeley Lab also supports 300 scientists and staff at off-site locations, 


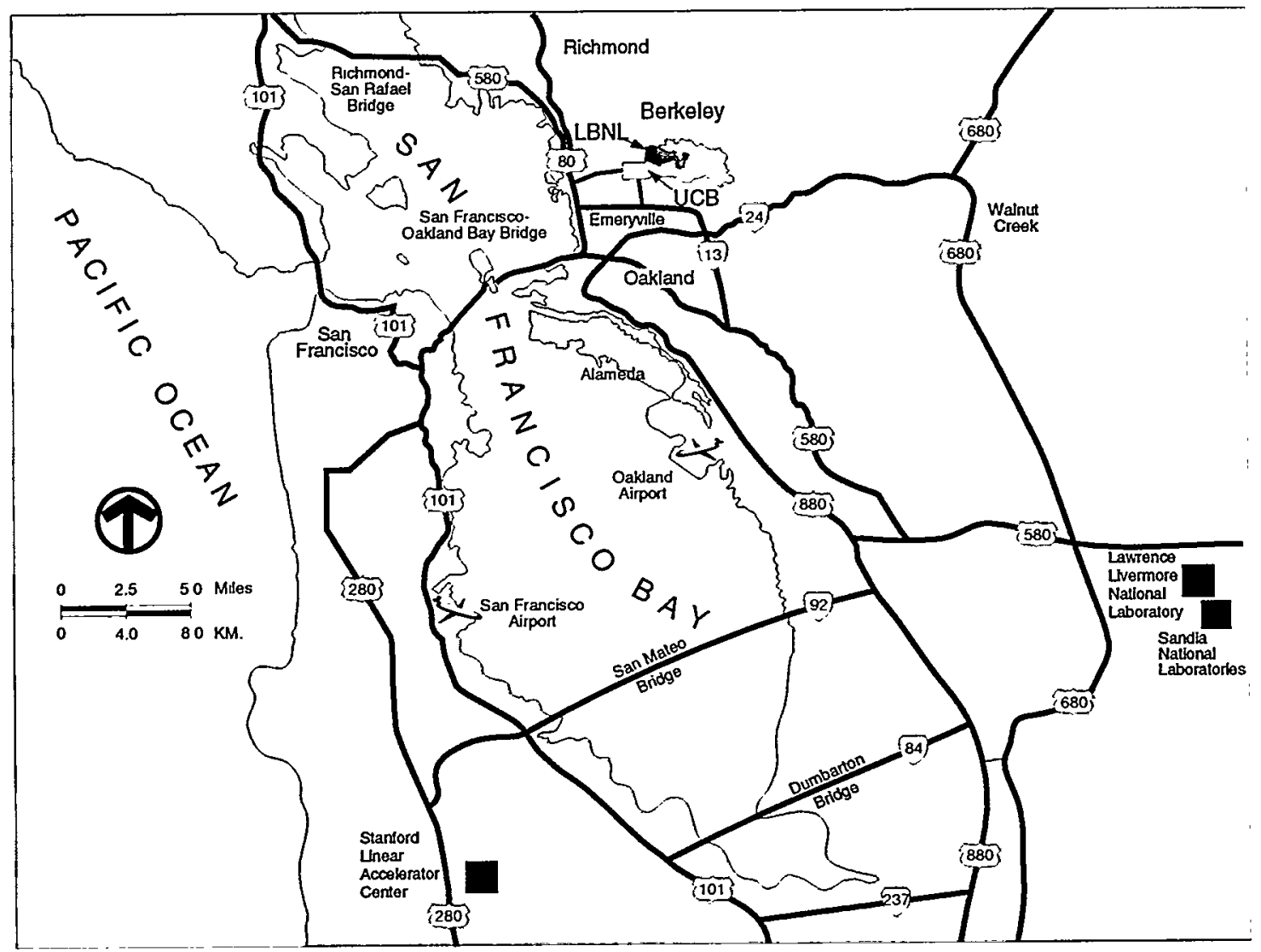

Figure 2-1 San Francisco Bay Area Map

including Walnut Creek and Washington, D.C. About 300 of the Laboratory's scientists serve as faculty members at UC Berkeley and UC San Francisco.

Berkeley Lab research and support activities are conducted in structures having a total area of 186,000 gross square meters (2-million gross square feet). Eighty-seven percent of this space is on the main site, $3 \%$ is on the UC Berkeley campus (i.e., Donner and Calvin laboratories), and the remaining $10 \%$ is located in various other off-site buildings. There are 80 permanent buildings and 107 trailers and temporary buildings on the main site. Figure 2-4 shows the Berkeley Lab space distribution.

\section{$\S 2.4 \quad$ C. Water Supply}

All the Laboratory's domestic water is supplied by the East Bay Municipal Utility District (EBMUD). There are no drinking water wells on site.

Domestic water originates in Sierra Nevada watershed lands before being transported to the Bay Area and ultimately to Berkeley Lab through a system of lakes, aqueducts, treatment plants, and pumping stations. EBMUD tests for contaminants and meets disinfection standards required by the Safe Drinking Water Act. In spring 1998, EBMUD converted from chlorine to chloramine as a disinfection agent throughout its supply area. 


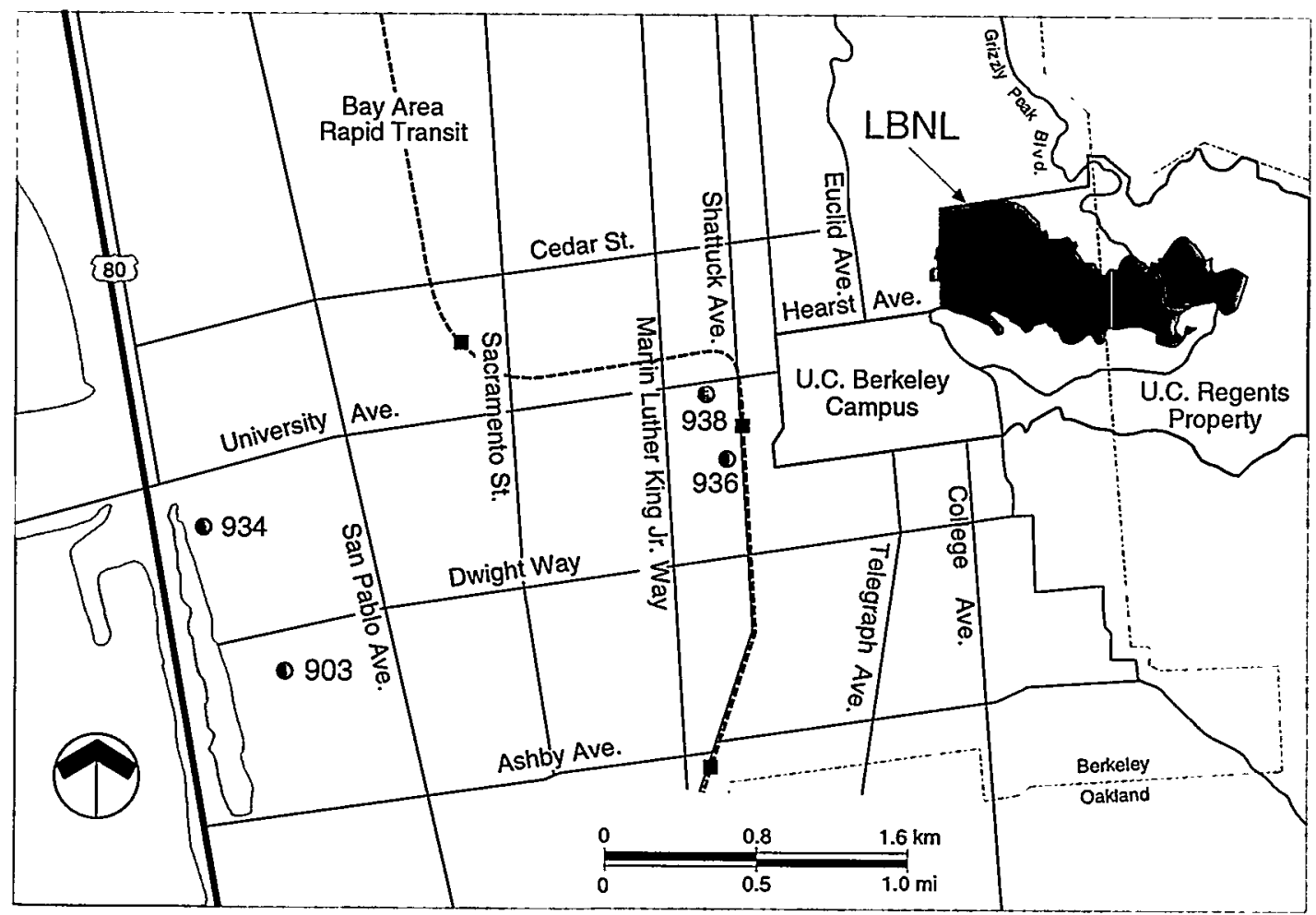

Figure 2-2 Vicinity Map

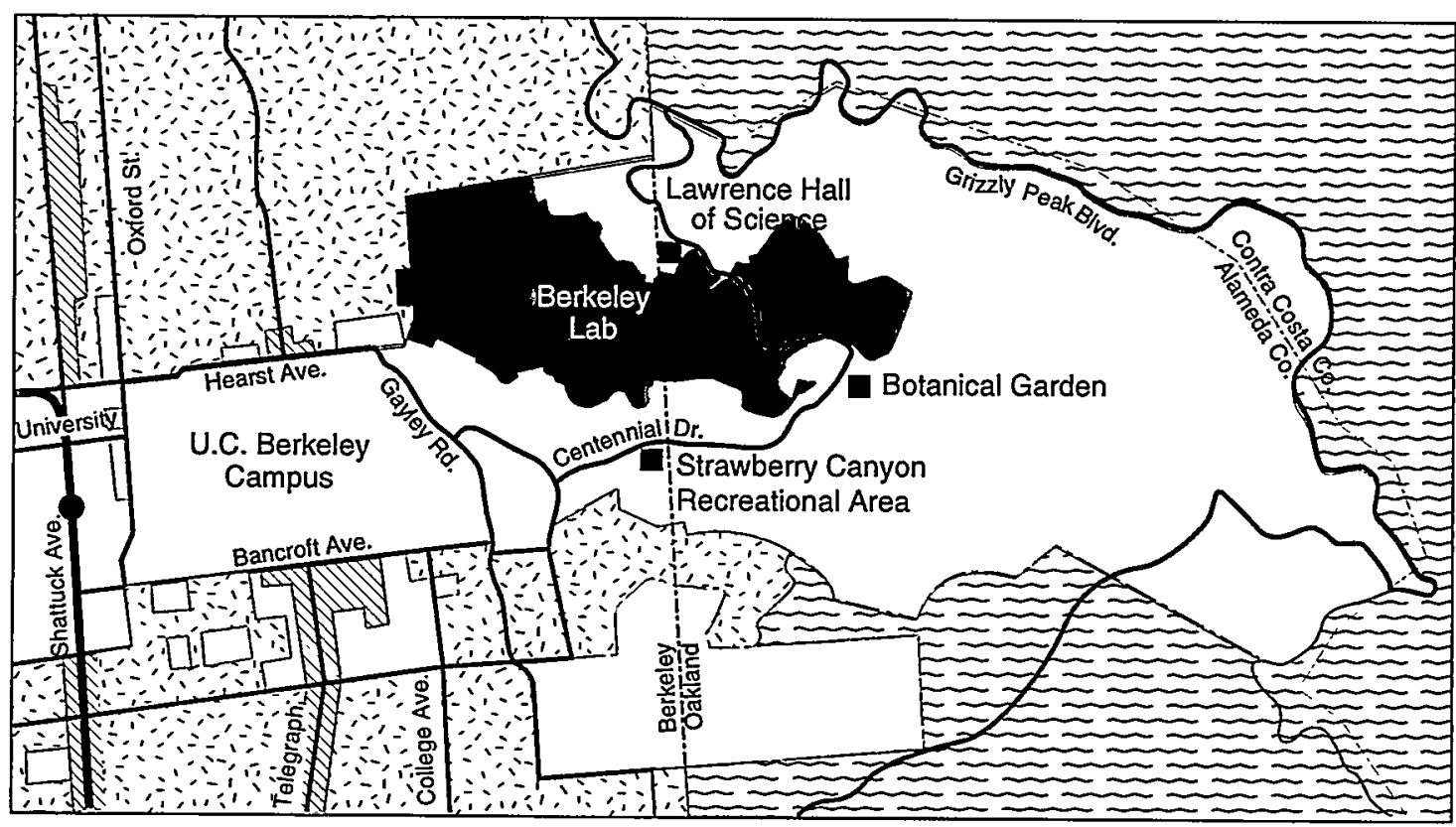

$\because 9$ Residential

Commencial

Central business district

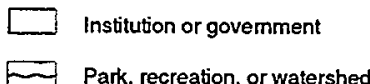

0 Park, recreation, or watershed

Thoroughtare

- BART Station

Figure 2-3 Adjacent Land Use 


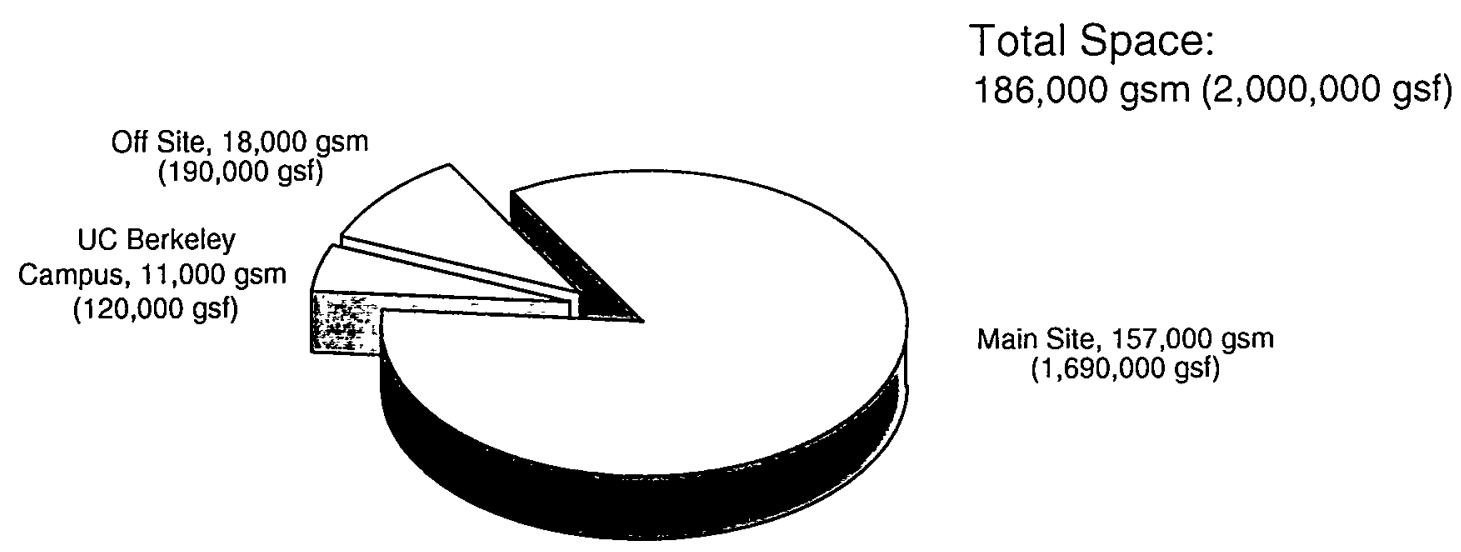

Figure 2-4 Space Distribution

The use of chloramine enables EBMUD drinking water to meet more stringent Safe Drinking Water Act standards for disinfection byproducts.

The water supply system is highly reliable for both domestic use and emergency purposes. This reliability is ensured by two separate connections to EBMUD's Shasta and Berkeley View sources and two 760,000-liter (200,000-gallon) on-site storage tanks. All Laboratory water is supplied by gravity feed. The entire system has sufficient capacity to meet the flow-rate and duration requirements for fire protection.

\section{ENVIRONMENTAL SETTING}

\section{$\$ 2.5 \quad$ A. Meteorology}

Characterized as Mediterranean, the climate at the site is influenced by the moderating effects of nearby San Francisco Bay and the Pacific Ocean to the west and the sheltering effects of the hills that stretch along the eastern shore of San Francisco Bay. These physical barriers contribute significantly to the site's relatively cool, dry summers and warm, wet winters. The mean annual temperature for 1998 was $11.8^{\circ} \mathrm{C}$ $\left(53.2^{\circ} \mathrm{F}\right)$. The yearly extremes ranged from a high of $33.4^{\circ} \mathrm{C}\left(92^{\circ} \mathrm{F}\right)$ on August 3 to a low of $-2.6^{\circ} \mathrm{C}\left(27^{\circ} \mathrm{F}\right)$ on December 21 . Figure $2-5$ traces the monthly temperature extremes for the year, recorded at the on-site weather station.

On-site wind patterns change little from one year to the next. The most common wind pattern occurs when larger-scale high-pressure systems block storm currents from reaching the area. This condition results in daytime westerly winds blowing off the Bay and moderating temperatures east of the hills in the interior valleys. Nighttime winds ordinarily reverse direction, driven by lighter southeasterly drainage winds that originate in the East Bay hills.

The other predominant wind pattern occurs when storm systems pass through the region. These systems arise most frequently during the winter months. South to southeast winds pass over the site before storms, shifting to the west or northwest after passage of each storm. A graphical summary of the annual wind patterns, called a windrose, illustrates the frequency of the two predominant patterns. The windrose for 1998 is displayed in Figure 2-6. The average wind speed for the year was 2.1 meters per second (4.7 miles 


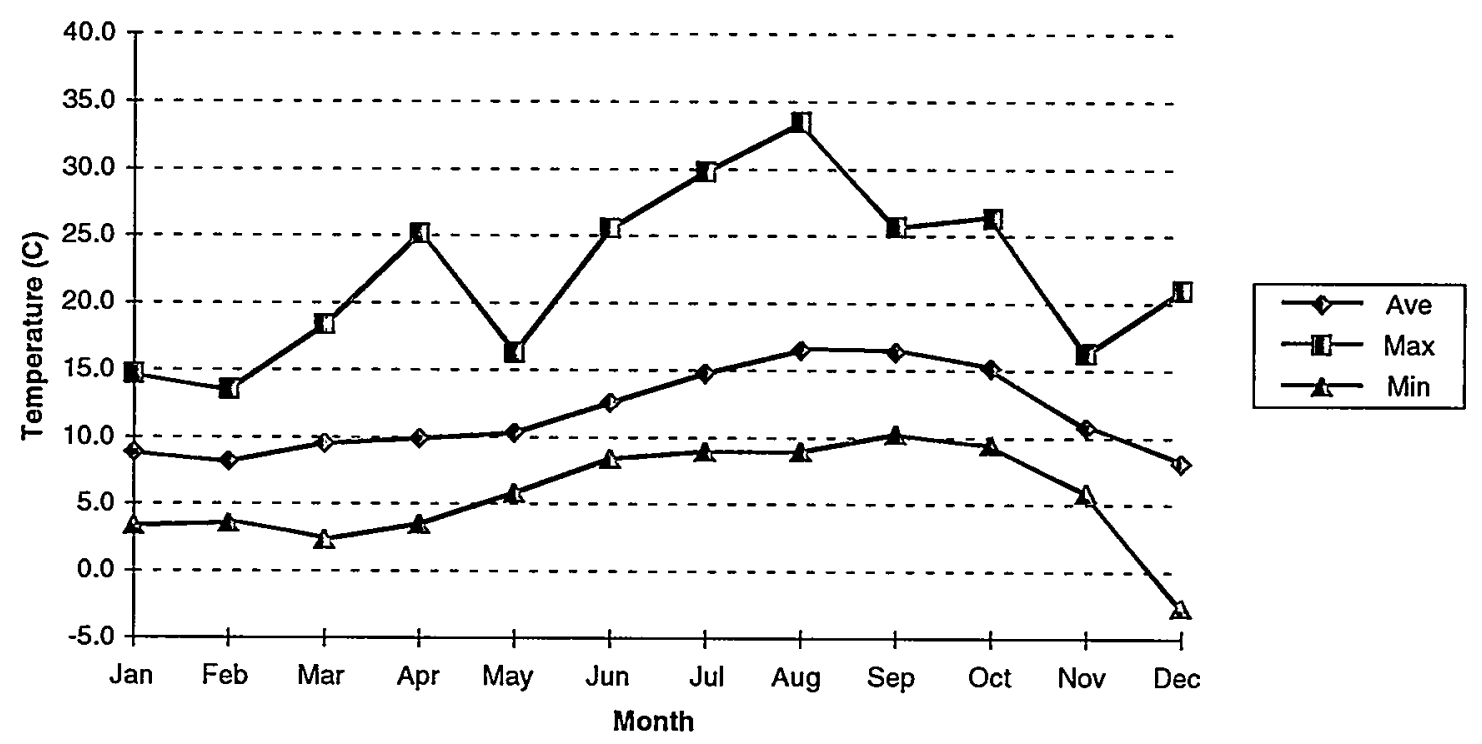

Figure 2-5 Temperature Summary by Month

per hour). The maximum wind speed during 1998 occurred on February 7, when winds gusted to nearly 25 meters per second (more than 55 miles per hour).

Yearly precipitation is totaled over a period called the water year, which runs from October 1 to the following September 30. The storms of the winter months produce nearly all the precipitation that the Laboratory receives during the water year. The average annual precipitation at the site since the 1974-1975 water year is about 71 centimeters ( 28 inches). For the last five water years, which includes the recordsetting 1997-1998 El Niño period when nearly 152 centimeters (60 inches) of precipitation fell, annual precipitation has been above normal. The annual average precipitation since 1993-1994 has been 98 centimeters (38 inches). Figure 2-7 compares 1998 monthly precipitation totals to the average since 1974.

\section{$\$ 2.6$ B. Vegetation}

In its maintenance and landscaping efforts, Berkeley Lab's vegetation management program reinforces native vegetation and avoids disruption of outlying natural habitats wherever possible. Because visual screening of the Laboratory is an important community objective, the Laboratory works to maintain and renew groves of nonnative trees that are important to this screening effect. No rare, threatened, or endangered species of plants are present on the site. See Figure 2-8.

Berkeley Lab updated and intensified its fire management efforts after the October 1991 fire in the Berkeley/Oakland Hills to the south. The Laboratory used natural successional trends of existing vegetation to reduce fire risks.

Berkeley Lab also works with the Hills Emergency Forum (made up of the neighboring cities of Berkeley and Oakland, the East Bay Regional Park District, the East 


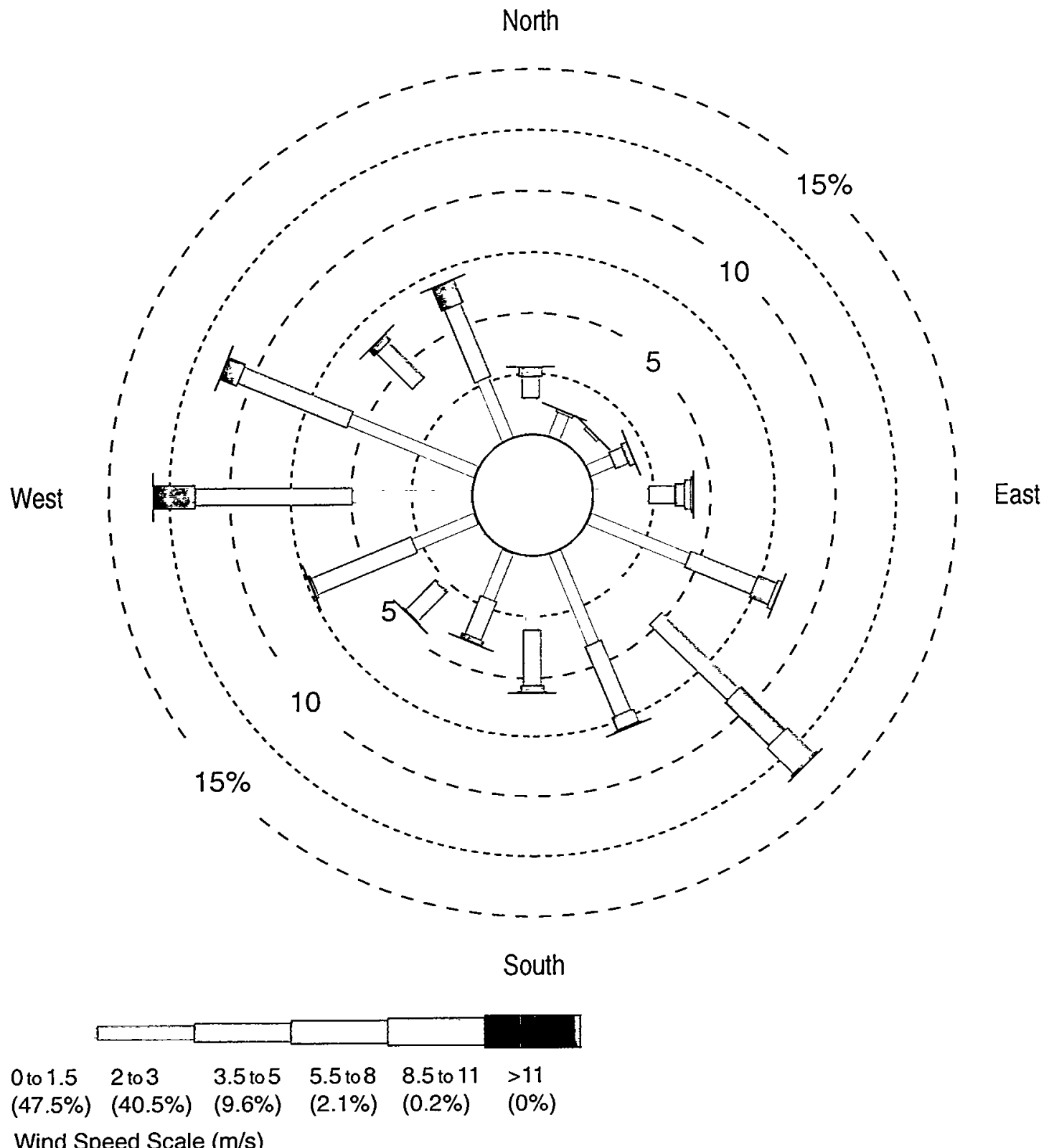

Wind Speed Scale $(\mathrm{m} / \mathrm{s})$

Note: Wind direction vane is the direction the wind is blowing from.

Figure 2-6 Annual Wind Patterns 


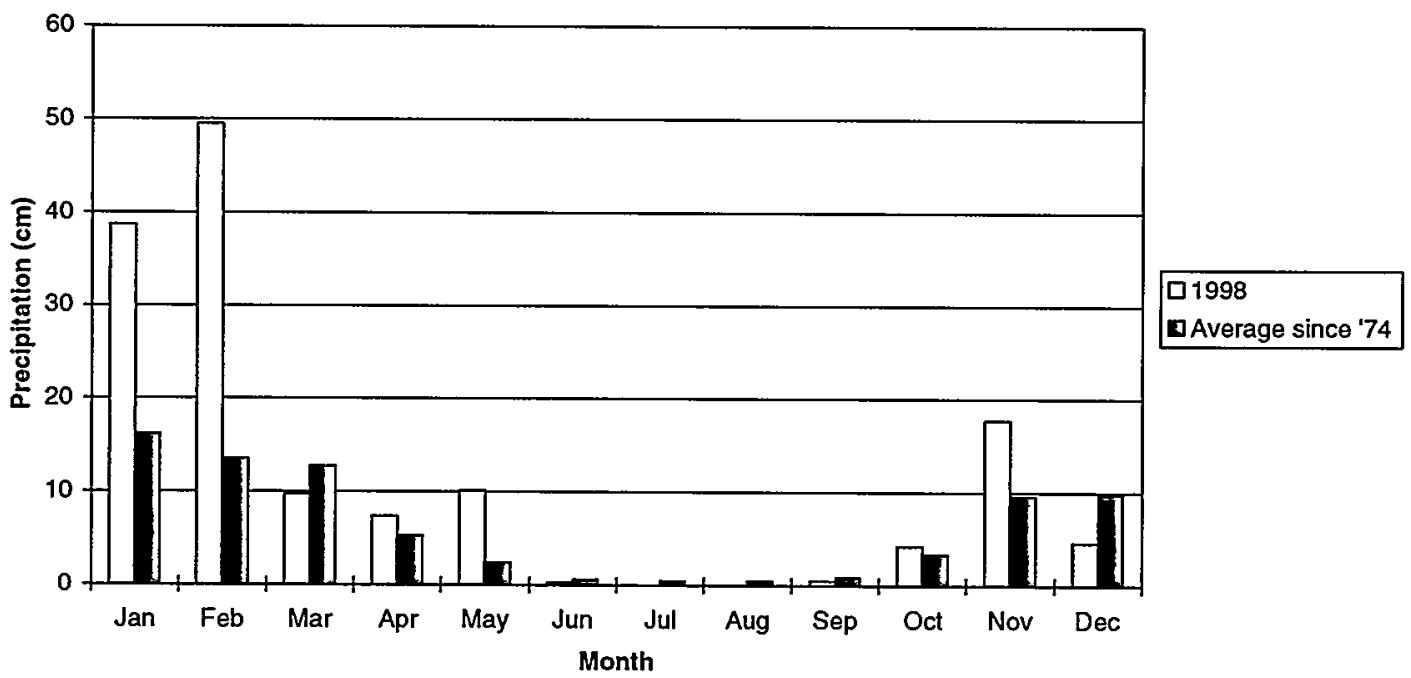

Figure 2-7 Precipitation Summary by Month

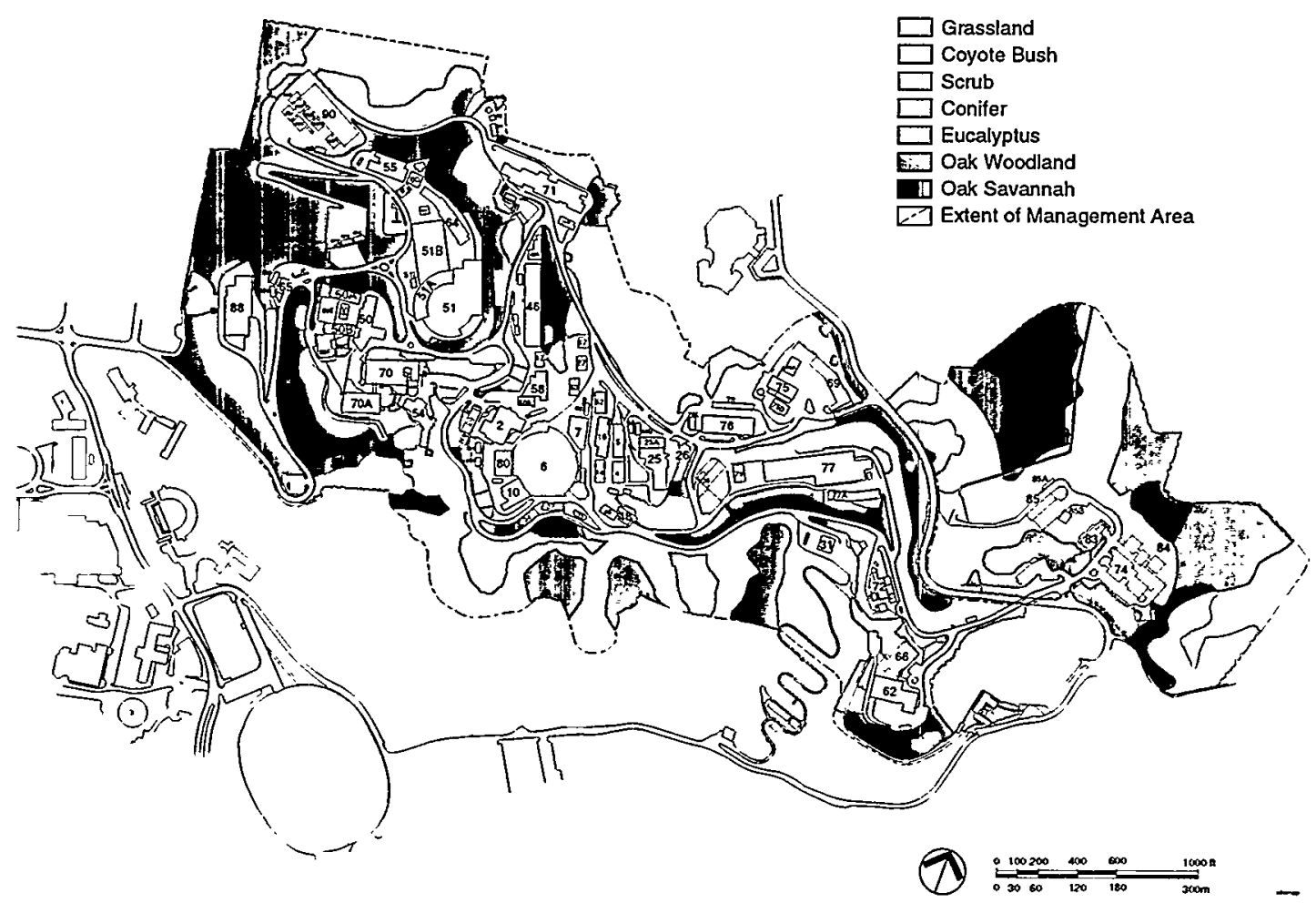

Figure 2-8 Vegetation Types 
Bay Municipal Utility District, and UC Berkeley) to improve vegetation management of the urban-wildland interface in the larger area.

\section{$\$ 2.7$ C. Wildlife}

Wildlife is abundant in the area surrounding Berkeley Lab because the site is adjacent to open spaces managed by the East Bay Regional Park District and the University of California. Berkeley Lab's grasses and brushlands provide cover, food, and breeding sites for wildlife typical of disturbed (e.g., previously grazed) areas with a Mediterranean climate located in mid-latitude California. Over 120 species of birds, mammals, and reptiles/amphibians-none of which is rare, threatened, or endangered-exist on the site. The most abundant large mammal is the Columbian blacktail deer. The Laboratory's tree stands offer nesting and cover sites for many resident and migratory species of birds.

\section{$\$ 2.8$ D. Geology}

Berkeley Lab is underlain by sedimentary and volcanic rocks between the Hayward Fault and the Wildcat Fault. The active Hayward Fault, a branch of the San Andreas Fault System, trends northwest-to-southeast along the base of the hills at the Laboratory's western edge. The inactive Wildcat Fault traverses the site north to south along the canyon at the Laboratory's eastern edge. Shorter, apparently inactive, subsidiary faults also transect the Laboratory.

Landsliding, paleotopography, interbedding, faulting, and tilting of the sedimentary and volcanic rocks underlying the site have created a complex geological structure. Three geologic formations underlie the majority of the site:

- The western and southern parts are underlain by moderately to well-consolidated upper Cretaceous marine sediments belonging to the Great Valley Group.

- The upper Miocene or lower Pliocene Orinda Formation overlies the Cretaceous rocks and underlies most of the site. It consists of claystones, siltstones, sandstones, and conglomerates formed from river-deposited sediments.

- The volcanic upper Miocene Moraga Formation underlies most of the higher elevations of the Laboratory as well as much of the area around the Advanced Light Source. The Moraga Formation consists of basalt and andesite, agglomerates, and pyroclastic tuffs.

The Miocene Claremont Formation and San Pablo Group are two additional geologic formations found on site, but they underlie only the far easternmost area. The Claremont Formation consists of chert and shale. The San Pablo Group consists of marine sandstones.

Weathered detritus from the rock formations underlying the site has accumulated as soil deposits. These deposits are generally two to several meters thick throughout the site. Because of the hilly terrain, grading and filling have been necessary to provide suitable building sites. Consequently, cuts up to tens of meters deep have been made, and fills up to tens of meters thick have been placed.

During the past 20 years, the Laboratory has carried out a successful program of slope stabilization to reduce the risk of property damage caused by potential soil movement. 
This program includes shallow dewatering wells, vegetation cover, and soil retention structures.

\section{$\$ 2.9$ E. Hydrogeology}

Hydrogeology at Berkeley Lab is complex. Year-round springs, annual surface seeps, and variable water levels in observation wells indicate discontinuous and localized aquifers. These conditions are caused by a number of factors. The various rock units underlying the site have different permeabilities. Volcanic rocks are typically fractured, readily allowing groundwater to flow, while sedimentary rocks consist of interbedded impervious claystones and siltstones and include moderate-permeability sandstones. Orinda Formation sandstones are discontinuous and probably exist primarily as channel fillings in the claystones and siltstones. The relationship between high-permeability volcanic rocks and low-permeability sedimentary rocks is complex because of landsliding and paleotopography.

Groundwater flow is a concern at the Laboratory because of its potential effect on slope stability as well as the underground movement of potential contaminants. Hydraulic conductivity is a term used to describe how fast groundwater can move through a medium such as volcanic rock. Hydraulic conductivity in the three major geologic formations is as follows:

- Although the Great Valley Group consists primarily of low-permeability rock material, its moderately spaced open fractures allow for groundwater movement. The hydraulic conductivity ranges between approximately $10^{-5}$ and $10^{-7}$ meters per second $\left(3.3 \times 10^{-5}\right.$ and $3.3 \times 10^{-7}$ feet per second).

- The Orinda Formation has a smaller hydraulic conductivity, generally ranging between $10^{-7}$ to $10^{-9}$ meters per second $\left(3.3 \times 10^{-7}\right.$ to $3.3 \times 10^{-9}$ feet per second), because it generally consists of low-permeability siltstone, which has closed fractures due to its low strength. Because the Orinda Formation usually underlies the Moraga Formation, it forms a relatively impermeable boundary for groundwater flow.

- The hydraulic conductivity within the Moraga Formation is relatively high, generally ranging between $10^{-4}$ and $10^{-6}$ meters per second $\left(3.3 \times 10^{-4}\right.$ and $3.3 \times 10^{-6}$ feet per second). The rocks of this formation constitute the main water-bearing unit at Berkeley Lab. Although this rock material has low permeability, groundwater flows readily through the numerous fractures, which are open because of the rock's high strength. The presence of low-permeability interbeds of fine-grained sediments, as well as zones with little fracturing, creates perched water conditions at many locations.

The fractured bedrock underlying Berkeley Lab allows percolation that augments groundwater. The complex geology at the Laboratory results in water-table depths that vary from 0 to 30 meters ( 98 feet) below the surface across the site. 


\section{Environmental Program Summary}

I. INTRODUCTION $\$ 3.1$

II. OVERVIEW OF ENVIRONMENTAL RESPONSIBILITIES \$3.2

Figure 3-1: Berkeley Lab Environment, Health, and Safety Division Organization

III. PROGRAM SUMMARY
A. Summary of Environmental Permits
$\$ 3.3$
Table 3-1: Environmental Permits Held by Berkeley Lab at End of 1998
B. Summary of Audits and Inspections $\$ 3.4$
C. Summary of Reportable Environmental Incidents $\$ 3.5$
Table 3-2: Environmental Audits, Inspections, and Appraisals in 1998
Table 3-3: Summary of Environmental Incidents During 1998
IV. PROGRAM REVIEW

A. Air Quality (Clean Air Act) $\$ 33.6$

1. Radiological $\$ 3.7$

2. Nonradiological $\$ 3.8$

Table 3-4: BAAQMD Permitted Air Emission Sources Active at End of 1998

B. Environmental Restoration (Comprehensive Environmental Response, Compensation, and Liability Act; Resource Conservation and Recovery Act Corrective Action Program) $\$ 3.9$

C. Hazardous Materials

1. Emergency Planning and Community Right-To-Know Act $\$ \mathbf{\$ 3 . 1 0}$

a. Toxic Release Inventory \$3.11

Table 3-5: Trends in Highest Quantities of EPCRA Toxic Release Inventory Reporting

b. Hazardous Materials Management Plan

$\$ 3.12$

c. Risk Management and Prevention Plan $\$ 3.13$

2. Federal Insecticide, Fungicide, and Rodenticide Act

$\$ 3.14$

3. Toxic Substances Control Act $\$ 3.15$

Figure 3-2: Trends in Eliminating Regulated PCBs 
D. Hazardous Waste (Resource Conservation and Recovery Act)

$\$ 3.16$

1. Hazardous Waste $\$ 3.17$

Table 3-6: Fixed Treatment Units Subject to State's Tiered Permitting

2. RCRA Corrective Actions Program (Site Environmental

Restoration) \$3.18

3. Medical Waste $\$ 3.19$

4. Underground Storage Tanks $\$ 3.20$

Table 3-7: Underground Storage Tank Operating Permits from City of Berkeley

E. Pollution Prevention and Waste Minimization

1. Executive Order 13301 (Greening the Government through Waste Prevention, Recycling, and Federal Acquisition) $\quad \$ 3.21$

2. Hazardous Waste Source Reduction and Management Review Act \$3.22

3. Pollution Prevention Act of $1990 \quad \$ 3.23$

F. Water Quality

1. Clean Water Act $\$ 3.24$

a. Wastewater $\$ 3.25$

b. Stormwater \$3.26

c. Aboveground Storage Tanks $\$ 3.27$

Figure 3-3: Aboveground Storage Tank Locations

2. Safe Drinking Water Act $\$ 3.28$

V. PROGRAM PERFORMANCE
A. Overview $\$ 3.29$
B. Process Performance Measures $\$ \mathbf{\$ 3 . 3 0}$
C. Outcome Performance Measures \$3.31

1. Radiation Protection of Public and Environment $\$ \mathbf{\$ 3 . 3 2}$

2. Tracking Environmental Incidents \$3.33

Figure 3-4: Quarterly Radiation Dose to Public

Figure 3-5: Quarterly Radiological Emissions to Air

Figure 3-6: Quarterly Radiological Effluent Discharged to Sanitary Sewer

3. Waste Reduction and Recycling \$3.34

Figure 3-7: Trends in Reducing Routine Nonhazardous or Sanitary Waste

Figure 3-8: Trends in Reducing Routine Hazardous Waste

Figure 3-9: Trends in Reducing Routine Mixed Waste

Figure 3-10: Trends in Reducing Routine Low-Level Radioactive Waste 


\section{$\$ 3.1 \quad$ I. INTRODUCTION}

This chapter provides an overview of Berkeley Lab's environmental management program, reviews the status of various compliance programs and activities, and presents measures of the Laboratory's environmental performance in key areas for 1998.

\section{\$3.2 II. OVERVIEW OF ENVIRONMENTAL RESPONSIBILITIES}

The Environment, Health, and Safety Division (EH\&S) is responsible for administering environmental protection and compliance programs at Berkeley Lab. The organizational structure of EH\&S for 1998 is shown in Figure 3-1.

The Environmental Protection Group (EPG) oversees sitewide environmental compliance activities, provides technical assistance to Laboratory staff, and assesses site characterization and cleanup. Environmental monitoring programs are an important component, providing critical information to demonstrate compliance and make programmatic decisions. For 1998 monitoring result summaries, see chapters $4-10$. The Waste Management Group (WMG) manages hazardous, medical, radioactive, and mixed (hazardous and radioactive) waste generated at the Laboratory. The Radiation Protection Group (RPG) is responsible for the safe use of radiation sources at Berkeley Lab, including both machine sources (e.g., accelerators) and radioisotopes.

\section{PROGRAM SUMMARY}

\section{\$3.3 A. Summary of Environmental Permits}

Certain Berkeley Lab activities require operating permits from environmental regulatory agencies. Table 3-1 summarizes the active permits held by Berkeley Lab at the end of the year by area of environmental activity.

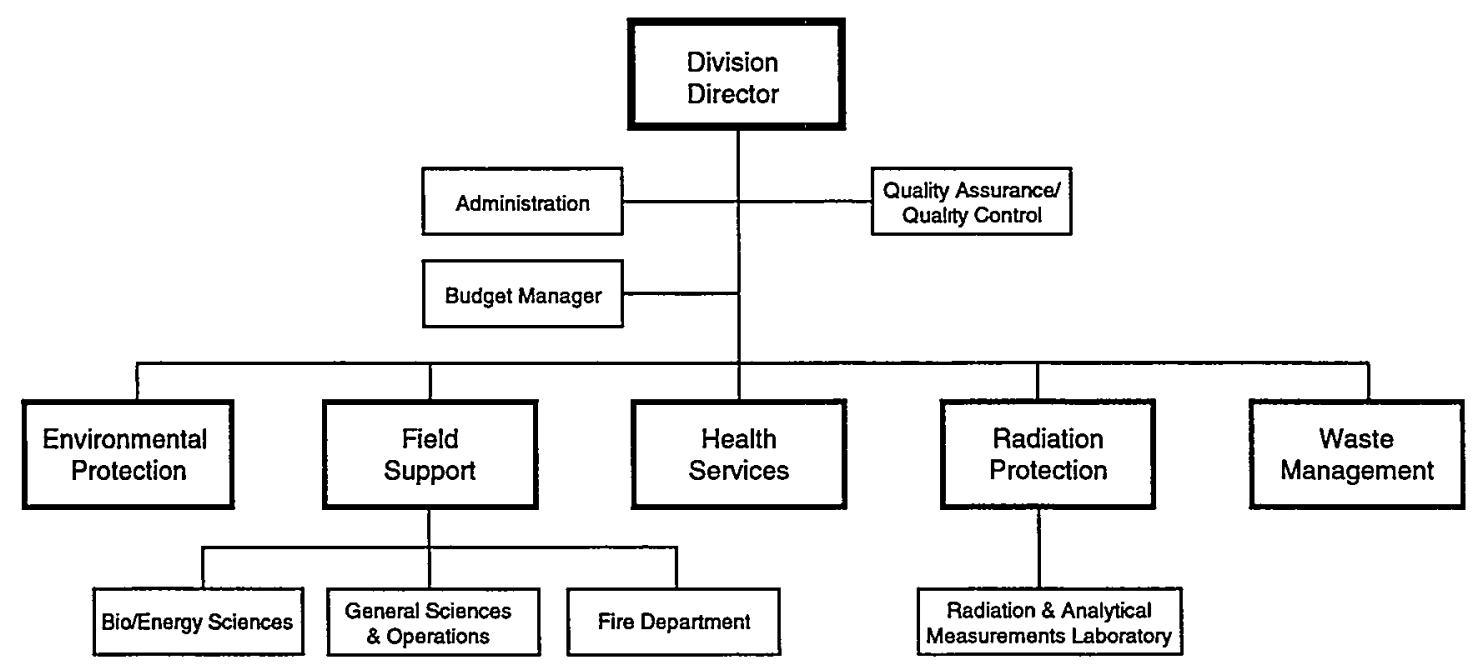

Figure 3-1 Berkeley Lab Environment, Health, and Safety Division Organization 
Table 3-1 Environmental Permits Held by Berkeley Lab at End of 1998

\begin{tabular}{|c|c|c|c|c|}
\hline Type of permit & $\begin{array}{l}\text { Issuing } \\
\text { agency }\end{array}$ & Description & $\begin{array}{c}\text { Number } \\
\text { of permits }\end{array}$ & $\begin{array}{l}\text { Section for more } \\
\text { information }\end{array}$ \\
\hline Air quality & BAAQMD & $\begin{array}{l}\text { Various activities with } \\
\text { atmospheric emissions }\end{array}$ & 6 & $\S 3.8$ \\
\hline Hazardous waste & DTSC & $\begin{array}{l}\text { Hazardous Waste } \\
\text { Handling Facility } \\
\text { operations and hazardous } \\
\text { waste treatment units }\end{array}$ & 2 & $\S 3.17$ \\
\hline Stormwater & SWRCB & $\begin{array}{l}\text { Site-wide stormwater } \\
\text { discharges }\end{array}$ & 1 & $\S 3.26$ \\
\hline $\begin{array}{l}\text { Underground } \\
\text { storage tank }\end{array}$ & $\begin{array}{l}\text { City of } \\
\text { Berkeley }\end{array}$ & $\begin{array}{l}\text { Underground storage } \\
\text { tanks containing petroleum } \\
\text { products }\end{array}$ & 8 & $\$ 3.20$ \\
\hline Wastewater & EBMUD & $\begin{array}{l}\text { Sitewide and operation- } \\
\text { specific wastewater } \\
\text { discharges to sanitary } \\
\text { sewer }\end{array}$ & 4 & $\S 3.25$ \\
\hline
\end{tabular}

\section{$\$ 3.4$ B. Summary of Audits and Inspections}

The agencies regulating the environmental programs at Berkeley Lab periodically inspect the Laboratory. Table 3-2 lists the inspections by these agencies that occurred at Berkeley Lab during 1998. The list includes self-monitoring inspections conducted by Berkeley Lab as required by East Bay Municipal Utility District (EBMUD) wastewater discharge permits because these activities expose the Laboratory to potential regulatory violations. Out of 29 inspections, Berkeley Lab received five violations in 1998. See $\S \S 3.17,3.19,3.25$.

\section{\$3.5 C. Summary of Reportable Environmental Incidents}

Berkeley Lab filed four reports with the Department of Energy (DOE) for minor environmental incidents in 1998 that were reportable under the DOE occurrencereporting program. ${ }^{1}$ No injuries, accidents, or damage resulted from these incidents. Table 3-3 identifies these incidents and the sections that provide additional details on each incident.

\section{PROGRAM REVIEW}

\section{\$3.6 A. Air Quality (Clean Air Act)}

The Clean Air Act ${ }^{2}$ is the key statutory reference for federal, state, and local air pollution control programs. It classifies air pollutants into several main categories:

- Criteria air pollutants (e.g., carbon monoxide, nitrogen oxides, particulate matter);

- Hazardous air pollutants (e.g., radionuclides, volatile air toxics); and

- Ozone-depleting substances (e.g., chlorofluorocarbons or "freons"). 
The State of California's own air pollution control program ${ }^{3}$ gives it additional powers to control sources of air emissions. Berkeley Lab divides its air quality protection and compliance activities into two categories: radiological (see \$3.7) and nonradiological (see $\$ 3.8)$.

Table 3-2 Environmental Audits, Inspections, and Appraisals in 1998

\begin{tabular}{|c|c|c|c|c|}
\hline Organization & Inspection title & Start date & $\begin{array}{l}\text { Length } \\
\text { (days) }\end{array}$ & Violations \\
\hline $\begin{array}{l}\text { City of } \\
\text { Berkeley }\end{array}$ & Inspection of several generator areas & October 9 & 1 & 0 \\
\hline DHS & Medical Waste Program & April 29 & 1 & $2^{a}$ \\
\hline \multirow[t]{2}{*}{ DTSC } & Hazardous Waste Handling Facility & June 18 & 1 & $1^{\mathrm{a}}$ \\
\hline & $\begin{array}{l}\text { National Tritium Labeling Facility } \\
\text { Treatability Study }\end{array}$ & August 24 & 1 & $N / A^{b}$ \\
\hline \multirow[t]{10}{*}{ EBMUD } & \multirow{3}{*}{$\begin{array}{l}\text { Wastewater monitoring inspections at } \\
\text { B25 Treatment Unit }\end{array}$} & January 14 & 1 & 0 \\
\hline & & July 8 & 1 & 0 \\
\hline & & November 6 & 1 & 0 \\
\hline & \multirow{4}{*}{$\begin{array}{l}\text { Wastewater monitoring inspections at } \\
\text { Hearst and Strawberry Outfalls }\end{array}$} & January 22 & 1 & 0 \\
\hline & & April 27 & 1 & 0 \\
\hline & & July 14 & 1 & 0 \\
\hline & & November 19 & 1 & 0 \\
\hline & \multirow{3}{*}{$\begin{array}{l}\text { Wastewater monitoring inspections at } \\
\text { B77 Treatment Unit }\end{array}$} & August 11 & 1 & 0 \\
\hline & & August 17 & 1 & 1 \\
\hline & & November 3 & 1 & 0 \\
\hline \multirow[t]{14}{*}{ LBNL } & \multirow{5}{*}{$\begin{array}{l}\text { EBMUD self-monitoring inspections at } \\
\text { Hearst and Strawberry Outfalls }\end{array}$} & February 16 & 1 & 0 \\
\hline & & April 6 & 1 & 0 \\
\hline & & July 13 & 1 & 0 \\
\hline & & August 11 & 1 & 0 \\
\hline & & November 9 & 1 & 0 \\
\hline & \multirow{7}{*}{$\begin{array}{l}\text { EBMUD self-monitoring inspections at } \\
\text { B77 Treatment Unit }\end{array}$} & February 9 & 1 & 0 \\
\hline & & July 6 & 1 & 1 \\
\hline & & August 3 & 1 & 0 \\
\hline & & September 22 & 1 & 0 \\
\hline & & September 23 & 1 & 0 \\
\hline & & September 24 & 1 & 0 \\
\hline & & October 12 & 1 & 0 \\
\hline & \multirow{2}{*}{$\begin{array}{l}\text { EBMUD self-monitoring inspections at } \\
\text { B25 Treatment Unit }\end{array}$} & April 13 & 1 & 0 \\
\hline & & December 7 & 1 & 0 \\
\hline BAAQMD & $\begin{array}{l}\text { Annual inspection of permitted air } \\
\text { emission sources }\end{array}$ & May 19 & 1 & 0 \\
\hline
\end{tabular}

${ }^{a}$ In the performance measure program, DOE, UC, and Berkeley Lab agreed to apply a weighting factor to three violations because they were minor in nature.

b Not applicable 
Table 3-3 Summary of Environmental Incidents During 1998

\begin{tabular}{|c|c|c|c|}
\hline $\begin{array}{c}\text { Incident } \\
\text { date }\end{array}$ & Report number & Description & $\begin{array}{c}\text { Section for more } \\
\text { information }\end{array}$ \\
\hline April 20 & $\begin{array}{l}\text { SAN-LBL-EHS- } \\
1998-0001\end{array}$ & $\begin{array}{l}\text { Release of washwater from old } \\
\text { Hazardous Waste Handling Facility }\end{array}$ & $\S 3.26$ \\
\hline May 8 & $\begin{array}{l}\text { SAN-LBL-EHS- } \\
1998-0002\end{array}$ & $\begin{array}{l}\text { Improper release and shipment of } \\
\text { radioactive waste samples }\end{array}$ & $\S 3.17$ \\
\hline July 9 & $\begin{array}{l}\text { SAN-LBL-ENG- } \\
1998-0001\end{array}$ & $\begin{array}{l}\text { Chromium discharge from Building } \\
77 \text { into sanitary sewer }\end{array}$ & $\S 3.25$ \\
\hline July 24 & $\begin{array}{l}\text { SAN-LBL-SBD- } \\
1998-0001\end{array}$ & $\begin{array}{l}\text { Tritium release of } 35 \text { curies from } \\
\text { National Tritium Labeling Facility }\end{array}$ & $\S 3.7$ \\
\hline
\end{tabular}

\section{$\$ 3.7$ 1. Radiological}

Radionuclides released to the atmosphere from Laboratory research activities must adhere to the standards in 40 CFR 61, Subpart H (National Emission Standards for Emissions of Radionuclides Other Than Radon from Department of Energy Facilities ${ }^{4}$ ) as well as DOE Orders $5400.1^{5}$ and $5400.5 .^{6}$ Subpart $\mathrm{H}$ is part of the National Emission Standards for Hazardous Air Pollutants (NESHAPs) program. US/EPA administers NESHAPs, while DOE administers Orders 5400.1 and 5400.5.

To properly account for radiological air emissions, Berkeley Lab conducts a preliminary review of all projects that may release radionuclides. This review includes a determination of the dose to the nearest off-site member of the public following NESHAPs regulations and DOE EH-0173T ${ }^{7}$ guidance. The assessment takes a conservative or worst-case approach by assuming that no portion of the release is collected by emission controls, even if such controls exist. Berkeley Lab's methodology for determining the appropriate level of sampling, monitoring, or administrative controls necessary to maintain compliance with NESHAPs has been approved by US/EPA and is summarized in Table 4-2. See \$4.2. Results of the emissions-sampling and monitoring program are also presented throughout chapter 4 . The Laboratory documents its NESHAPs compliance status with an annual report to the US/EPA, which is available on the Berkeley Lab's EH\&S Web site at http://www.lbl.gov/ehs/html/env_protection.htm.

On July 24, an unplanned tritium emission of $1.3 \times 10^{12} \mathrm{~Bq}$ (35 curies) took place at the National Tritium Labeling Facility (NTLF) during a waste treatability study. See \$3.17. Silica gel containing tritium was heated in a process kiln with a monitored but unfiltered exhaust system, causing release of tritium oxide to the environment. Although this release was below the minimum reportable threshold, the incident was reported to DOE and the City of Berkeley. Potential doses to the public from this emission were small $(0.03 \mathrm{mrem})$. Releases of this magnitude are not considered a public health threat by US/EPA. Corrective actions were implemented in 1998 to prevent recurrence of this type of unplanned tritium emission. 


\section{$\$ 3.8 \quad 2 . \quad$ Nonradiological}

The Bay Area Air Quality Management District (BAAQMD) implements federal and state air quality requirements for most non-NESHAPs air-emission activities. Mobile source activities are the notable exception.

At the end of 1998, Berkeley Lab had six activities holding BAAQMD operating permits 8 - three fewer than the previous year because (a) two sources were removed from service during the year and (b) one source was reclassified to exempt status during the annual inspection in May. Operating permits are renewed annually, at which time BAAQMD also requests information required by the state's Air Toxics "Hot Spots" Information and Assessment Act of $1987 . .^{\circ}$ For a list of active operating permits, see Table 3-4.

In 1998, Berkeley Lab came significantly closer to its goal of eliminating emissions of the most harmful Class I ozone-depleting substances (ODSs). The Ultra-High Vacuum Cleaning Facility (UHVCF) in Building 77 switched to a water-based, closed-loop ultrasonic cleaning system with a complementary vacuum drying oven. This new system allowed the UHVCF to remove its vapor-degreasing system (BAAQMD source \#92) and eliminate approximately 1,500 kilograms (3,300 pounds) of 1,1,1-trichloroethane emissions. Since beginning its ODS phaseout efforts in 1992, Berkeley Lab reduced its overall Class I ODS emissions nearly $99 \%$ to less than 100 kilograms (225 pounds).

Table 3-4 BAAQMD Permitted Air Emission Sources Active at End of 1998

\begin{tabular}{|c|c|c|c|c|}
\hline BAAQMD category & $\begin{array}{l}\text { BAAQMD } \\
\text { source \# }\end{array}$ & Description & Building & $\begin{array}{l}\text { Abatement } \\
\text { type }\end{array}$ \\
\hline Gasoline dispensing & 76 & Gasoline pumps & 76 & Vapor recovery \\
\hline $\begin{array}{l}\text { Surface coating } \\
\text { and printing }\end{array}$ & $\begin{array}{r}74 \\
96 \\
147\end{array}$ & $\begin{array}{l}\text { Paint spray booth } \\
\text { Paint spray booth } \\
\text { Epoxy mixing hood }\end{array}$ & $\begin{array}{l}76 \\
77 \\
53\end{array}$ & $\begin{array}{l}\text { Liquid separator } \\
\text { Dry filter } \\
\end{array}$ \\
\hline $\begin{array}{l}\text { Surface preparation } \\
\text { and cleaning }\end{array}$ & $\begin{array}{r}97 \\
188\end{array}$ & $\begin{array}{l}\text { Sandblast booth } \\
\text { Wipe-cleaning }\end{array}$ & $\begin{array}{c}77 \\
\text { Site-wide }\end{array}$ & $\begin{array}{l}\text { Baghouse } \\
-\end{array}$ \\
\hline
\end{tabular}

\section{§3.9 B. Environmental Restoration (Comprehensive Environmental Response, Compensation, and Liability Act; Resource Conservation and Recovery Act Corrective Action Program)}

The Comprehensive Environmental Response, Compensation, and Liability Act of 1980 (CERCLA) $^{10}$ was passed to regulate actual or threatened releases into the environment. Actions under CERCLA and related statutes include removal and/or remedial action if the release may present an imminent danger, as well as remedial investigations and feasibility studies that determine site cleanup options.

After considering information available in 1991 about historic Laboratory activities, US/EPA determined that environmental risks were low and did not warrant a CERCLAbased investigation. At the request of the Committee to Minimize Toxic Waste (CMTW), a local citizens group, the US/EPA reevaluated the Berkeley Lab site in 1998 to 
determine whether the site is eligible for the federal Superfund list. Formally known as the National Priorities List (NPL), the federal Superfund list is a list of uncontrolled or abandoned waste sites that have been identified by EPA as priorities for cleanup.

In evaluating Berkeley Lab for possible inclusion on the NPL, EPA considered data submitted by CMTW and additional data provided by DOE. EPA determined, based on screening criteria, that the site is eligible for the NPL. EPA also determined, however, that existing data indicate that low levels of tritium at Berkeley Lab are well below EPA clean air public health standards and do not indicate a need to add Berkeley Lab to the Superfund list. To make a final listing decision, EPA requested additional sampling of the air, water, and soil in and around the Laboratory. Berkeley Lab responded to this request by preparing sampling plans for air, vegetation, soil and sediment, and surface water. Sampling is scheduled to begin in 1999 and to be completed the following year.

Berkeley Lab continues to investigate specific areas of concern at the site under the requirements of the Corrective Action Program of the Resource Conservation and Recovery Act (RCRA). ${ }^{11}$ Because these areas of interest relate to groundwater protection, all monitoring efforts for the year are described in chapter 6 .

\section{Hazardous Materials}

\section{$\$ 3.10$ 1. Emergency Planning and Community Right-To-Know Act}

The Emergency Planning and Community Right-To-Know Act (EPCRA) was passed in 1986 as Title III of the Superfund Amendments and Reauthorization Act (SARA). ${ }^{12}$ This Act establishes requirements for emergency planning, notification, and reporting. In California, the requirements of SARA Title III are incorporated into the state's Hazardous Materials Release Response Plans and Inventory Law.13 Berkeley Lab activities addressing these requirements are summarized in $\$ \$ 3.11-3.13$.

\section{\$3.11 a. Toxic Release Inventory}

DOE facilities such as Berkeley Lab are required under Executive Order 12856 (Federal Compliance with Right-to-Know Laws and Pollution Prevention Requirements) ${ }^{14}$ to evaluate the applicability of the Toxic Release Inventory (TRI) reporting requirements of EPCRA. TRI reporting consists of two steps: (1) determining usage and (2) submitting US/EPA Form $R$ if threshold quantities are exceeded.

Berkeley Lab determined that no chemical usage during 1998 exceeded the TRI criterion of 4,536 kilograms $(10,000$ pounds) for a listed substance and that, therefore, preparation of a Form $\mathrm{R}$ was not necessary. Table 3-5 shows the highest usage levels of the chemicals from the Laboratory's assessment over the last several years, including several substances either recently removed from the TRI list by US/EPA or now listed by US/EPA for reasons of use or production not found at Berkeley Lab.

\section{$\$ 3.12$ b. Hazardous Materials Management Plan}

The City of Berkeley is the local administering agency for certain hazardous materials regulations falling under state law. Berkeley Lab voluntarily submits a Hazardous 
Table 3-5 Trends in Highest Quantities of EPCRA Toxic Release Inventory Reporting

\begin{tabular}{lrrrrrr}
\hline Substance & $\begin{array}{r}1993 \\
(\mathbf{k g})\end{array}$ & $\begin{array}{r}1994 \\
(\mathbf{k g})\end{array}$ & $\begin{array}{c}1995 \\
(\mathbf{k g})\end{array}$ & $\begin{array}{c}1996 \\
(\mathbf{k g})\end{array}$ & $\begin{array}{c}1997 \\
(\mathbf{k g})\end{array}$ & $\begin{array}{c}1998 \\
(\mathbf{k g})\end{array}$ \\
\hline Acetone & 475 & 495 & $-^{\mathrm{a}}$ & $285^{\mathrm{a}}$ & $-^{\mathrm{a}}$ & $-^{\mathrm{a}}$ \\
Chlorofluorocarbons & 1,305 & 130 & $-^{\mathrm{b}}$ & 120 & $185^{\mathrm{c}}$ & 143 \\
Hydrochloric acid & $-^{\mathrm{d}}$ & 205 & 2,722 & 468 & $-^{\mathrm{e}}$ & $-^{\mathrm{e}}$ \\
Isopropyl alcohol & $-\mathrm{d}$ & 315 & $-^{\mathrm{b}}$ & 294 & $493^{\mathrm{e}}$ & $-^{\mathrm{e}}$ \\
Methanol & $-\mathrm{d}$ & 145 & $-^{\mathrm{b}}$ & 158 & 260 & 266 \\
Nitric acid & 525 & 645 & $-^{\mathrm{b}}$ & 1,030 & 727 & 707 \\
Sulfuric acid & 4,265 & 2,195 & $-^{\mathrm{a}}$ & $1,161^{\mathrm{a}}$ & $-^{\mathrm{e}}$ & $-^{\mathrm{e}}$ \\
1,1,1-Trichloroethane & 1,715 & 1,565 & 1,148 & 1,023 & 1,521 & 69 \\
\hline
\end{tabular}

a Substance no longer required by US/EPA under this program.

${ }^{b}$ Usage for year less than US/EPA reporting threshold.

${ }^{c}$ Amount includes only 6 kilograms of Class 1 ozone-depleting substance released; remainder is considered

Class II.

dOnly seven major TRI chemicals reviewed in 1993.

e Substance not reportable, because use at Berkeley Lab does not meet recently updated TRI use or production criteria for listing.

Materials Management Plan (HMMP) ${ }^{15}$ to the City of Berkeley each year, although federal sovereign immunity from such regulations has not been waived.

The 1998 HMMP included a list of all hazardous materials present on site in amounts exceeding the state's aggregate threshold quantities (i.e., 208 liters (55 gallons) for liquids, 227 kilograms (500 pounds) for solids, and 5.7 cubic meters ( 200 cubic feet) for compressed gases). The plan included annotated floor plans and corresponding hazard lists for each building as well as summary documentation on emergency plans, procedures, and training.

\section{§3.13 c. Risk Management and Prevention Plan}

The City of Berkeley requires a Risk Management and Prevention Plan (RMPP) ${ }^{16}$ for operations using acutely hazardous materials above certain thresholds established in 40 CFR Part 355. Berkeley Lab does not have any operations that contain hazardous substances above the threshold quantities, and therefore no RMPP is required for the site.

\section{$\$ 3.14$ 2. Federal Insecticide, Fungicide, and Rodenticide Act}

Passed by Congress in 1972, the Federal Insecticide, Fungicide, and Rodenticide $\mathrm{Act}^{17}$ restricts the registration, sale, use, and disposal of pesticides. Pesticides, including insecticides and herbicides, are applied at the Berkeley Lab site by licensed contractors only. The Laboratory operates a composting program to minimize the use of herbicides and to reduce solid waste. The mulch generated from composting is used on site for weed screening and landscaping where herbicides were previously applied. The end products from the chipper and mulcher program are also used to control erosion. 


\section{$\$ 3.15$ 3. Toxic Substances Control Act}

The objective of the Toxic Substances Control Act (TSCA) ${ }^{18}$ is to minimize the exposure of humans and the environment to chemicals found in manufacturing, processing, commercial distribution, or disposal activities. TSCA establishes a protocol for evaluating chemicals before they are introduced into the marketplace and controlling their use once they are approved for manufacturing. TSCA regulations are administered by the US/EPA. Polychlorinated biphenyls (PCBs) remain the sole substance at Berkeley Lab currently affected by the TSCA regulations.

Since the TSCA program began, the Laboratory has removed all inventoried TSCAregulated $\mathrm{PCB}$ transformers (PCB concentration greater than $500 \mathrm{ppm}$ ). The remaining TSCA-PCB equipment is primarily large low- and high-voltage capacitors. Four of these capacitors are still in use or storage, containing an estimated 114 kilograms (250 pounds) of regulated PCB dielectric fluid. Figure 3-2 shows the trends in reducing regulated PCB transformers and capacitors at the site. Because of the low amounts of PCBs, the Laboratory is not required to prepare an annual PCB report for the EPA.

\section{\$3.16 D. Hazardous Waste (Resource Conservation and Recovery Act)}

The primary goal of the Resource Conservation and Recovery Act of 1976 (RCRA) ${ }^{19}$ is to ensure that hazardous waste management practices are conducted in a manner that

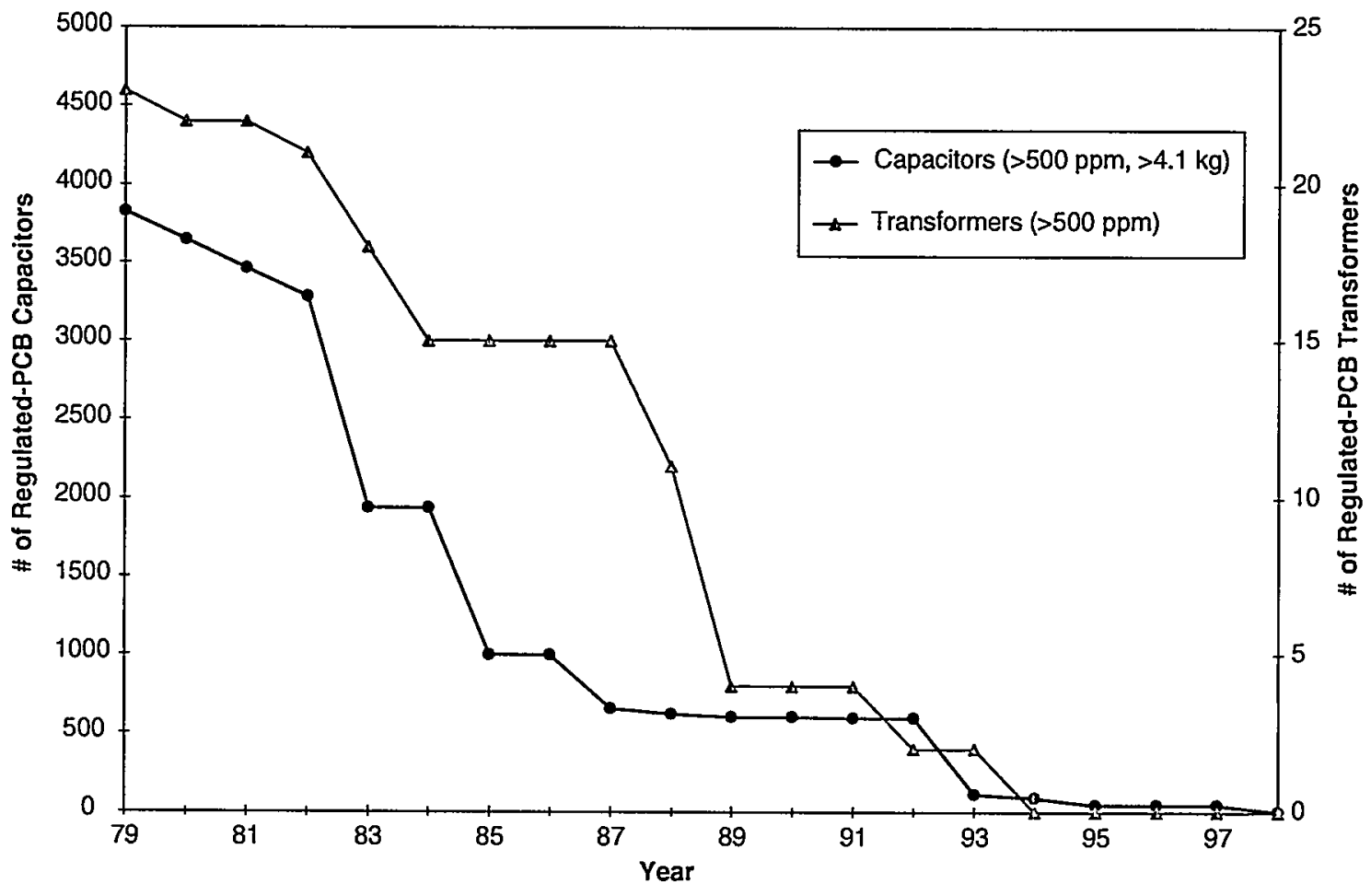

Figure 3-2 Trends in Eliminating Regulated PCBs 
protects human health and the environment. RCRA affects waste treatment, storage, and disposal activities at Berkeley Lab in three areas: hazardous waste (including the hazardous portion of mixed waste), medical waste, and underground storage tanks.

\section{$\$ 3.17$ 1. Hazardous Waste}

In California, the Department of Toxic Substances Control (DTSC) administers the RCRA hazardous waste program. The California program incorporates the provisions of both the federal and state hazardous waste ${ }^{20}$ laws. The state program includes both permitting and enforcement elements. The state's permitting program for hazardous waste treatment and storage facilities consists of five tiers. Listed in decreasing order of regulatory complexity, these tiers are:

- Full permit;

- Standardized permit;

- Permit-by-rule;

- Conditional authorization; and

- Conditional exemption.

Berkeley Lab's Hazardous Waste Handling Facility (HWHF) operates under the "full permit" tier of the program. A full permit is also known as a RCRA Part B permit. The current permit for the HWHF ${ }^{21}$ was approved by DTSC on May 4, 1993, and is valid for ten years. The permit allows for storage and simple treatment of certain hazardous and mixed wastes at the HWHF. Simple treatment includes neutralization, consolidation, solidification, and desensitization. Berkeley Lab's waste management program sends nearly all medical, hazardous, radioactive, and mixed waste generated at the Laboratory off site for disposal. In 1998, however, the waste management program conducted one sewer discharge of very low level radioactive waste in conformance with the EBMUD sanitary sewer permit.

A permit modification request filed by Berkeley Lab in January 1996 remains under consideration by DTSC. Described in earlier site environmental reports, this request asked for certain changes in waste streams, storage designations, treatment methods, training, and sampling. A May 1996 consent order by DTSC allows the Laboratory to continue HWHF operations under a revised set of permit conditions until DTSC makes a determination. That decision had been on hold pending a court decision on a lawsuit filed by a local citizens group in June 1997. In June 1998, the court dismissed this lawsuit. DTSC issued its final permit decision and approved the request to modify the HWHF Part B permit on May 20,1999, starting a 30-day public appeal period. The modifications did not become effective in June, because an appeal was submitted and is being evaluated by DTSC.

Berkeley Lab has an additional hazardous waste permit ${ }^{22}$ to operate five fixed treatment units (FTUs). FTU 001, located at Building 77 and authorized under permit-byrule, was closed in August 1998. An independent professional engineer certified the closure of FTU 001. The type and location of each unit are listed in Table 3-6. These treatment units operate independently of the HWHF. Three of these FTUs are authorized to operate under the "conditional authorization" tier, while the remaining two are 
Table 3-6 Fixed Treatment Units Subject to State's Tiered Permitting

\begin{tabular}{|c|c|c|c|}
\hline FTU & Building & Description of treatment & Permit tier \\
\hline 002 & 25 & Metals precipitation and acid neutralization & Permit-by-rule \\
\hline 003 & 76 & Oil/water separator & $\begin{array}{l}\text { Conditional } \\
\text { authorization }\end{array}$ \\
\hline 004 & $70 \mathrm{~A} 70 \mathrm{~F}$ & Acid neutralization & $\begin{array}{l}\text { Conditional } \\
\text { authorization }\end{array}$ \\
\hline 005 & 2 & Acid neutralization & $\begin{array}{l}\text { Conditional } \\
\text { authorization }\end{array}$ \\
\hline 006 & 77 & Metals precipitation and acid neutralization & Permit-by-rule \\
\hline
\end{tabular}

authorized to operate under the "permit-by-rule" tier. The level of treatment determines which tier applies. DTSC requests renewal of this permit each year. In April, the Laboratory submitted the 1998 FTU renewal package to DTSC and the City of Berkeley. Beginning in 2000, the City of Berkeley will oversee all future tiered permitting renewals.

In June, DTSC inspected the HWHF and reported a minor violation, which was corrected during the inspection. This violation consisted of two containers that had been accumulated for greater than one year in a generator area. The containers were already correctly stored in the HWHF, requiring no further corrective action. In August, the City of Berkeley inspected several generator areas under the authority of the Certified Unified Program Agency (CUPA). This inspection resulted in no violations. Waste management permits and regulations require Berkeley Lab to prepare several reports for the year:

- The Annual Hazardous Waste Report for $1998,{ }^{23}$ prepared for DTSC, contains generator and transport information for all hazardous waste (including the hazardous waste portion of mixed waste) activities at the HWHF during the reporting year.

- The Annual Waste Reduction Report, ${ }^{24}$ prepared for DOE, contains a detailed analysis of waste minimization efforts made by waste generators during the reporting year.

- Quarterly reports on the inventory of mixed waste that is more than one year old were generated to meet a DTSC operating permit requirement.

- Quarterly mixed waste management reports were generated in accordance with the previously described May 1996 DTSC consent order to summarize all efforts to use commercial mixed waste disposal facilities.

In late 1995, DTSC approved the Laboratory's Mixed Waste Site Treatment Plan (STP), ${ }^{25}$ which documents the procedures and conditions used by Berkeley Lab to manage its mixed waste streams. The Laboratory prepares update reports that quantify the amount of mixed waste in storage at the end of a reporting period and the anticipated amount that will be placed in storage during the next five fiscal years. These updates are prepared twice each year, covering the periods ending in March and September.

The Site Treatment Plan requires specific schedules for mixed waste treatment. As part of meeting these schedules, Berkeley Lab was required to identify preferred treatment 
options for each waste stream. One waste stream, consisting of high activity tritium and solvents, was originally slated for treatment at the Idaho National Engineering and Environmental Laboratory (INEEL) Waste Experimental Reduction Facility (WERF). A treatment system proposed for study by NTLF would treat the solvents but not release the tritium. This treatability study began in June 1996 and continues to study the destruction of solvents in various concentrations. More information can be found in the annual treatability study reports submitted to DTSC.

DOE's occurrence-reporting program is designed to track incidents at DOE facilities around the country. The program ranks incidents on a graded scale, using a rigid set of criteria. In May, a sample of radioactive waste was sent to an off-site analytical laboratory for analysis. See Table 3-3. Although the waste was found to have levels of radioactivity in excess of those authorized by that laboratory's license, the laboratory reported no contamination or personnel exposure. The sample was immediately returned to Berkeley Lab, which corroborated the analysis and determined that the sample had been incorrectly classified as an exempt quantity under 49 CFR 173.4. As a result, an approval program was developed to check all outgoing shipments of waste samples known or suspected of being radioactive.

\section{\$3.18 2. RCRA Corrective Actions Program (Site Environmental Restoration)}

The Environmental Restoration Program at Berkeley Lab is conducted under the RCRA corrective action program, as mentioned in $\$ 3.9$. It is intended to satisfy three criteria:

- Identification of areas of contamination that may have resulted from past releases of contaminants to the environment;

- Determination of the sources and extent of contamination; and

- Development and implementation of plans to remediate contaminated areas.

The RCRA Facility Investigation (RFI) Work Plan, ${ }^{26}$ which details environmental investigations necessary to characterize the site, was submitted to DTSC in October 1992. Now into the final phase of the RFI, Berkeley Lab submitted three RFI Work Plan Addenda $^{27}$ before initiating construction of groundwater monitoring wells and investigating areas of soil contamination. In addition to these addenda, the Laboratory submitted four work plans ${ }^{28}$ in 1998 for the implementation of Interim Corrective Measures (ICMs), including removal of contaminated soil and treatment of contaminated groundwater.

In February 1997, Berkeley Lab submitted a Draft Final RCRA Facility Investigation Report $^{29}$ to the regulatory agencies overseeing the investigation (i.e., DTSC, RWQCB, and the City of Berkeley). The report documents RFI activities through September 1996. A report addendum on subsequent RFI activities (October 1996 through completion of the RFI) is expected to be submitted to the regulatory agencies in mid-1999.

Finally, the Berkeley Lab environmental restoration program submitted four quarterly progress reports ${ }^{30}$ to DTSC in 1998 in accordance with RCRA Part B Permit 
requirements. These reports detail project activities conducted during each three-month period and activities planned for upcoming periods.

The Environmental Restoration Program maintains a proactive interaction with stakeholders, including DTSC, the Regional Water Quality Control Board, and the City of Berkeley. The program holds quarterly meetings at which the status of performed and planned activities is discussed. The program also holds technical workshops with the agencies. The technical meetings give the agencies a detailed description of results from field investigations and facilitate agency involvement in planning future activities.

\section{$\$ 3.19$ 3. Medical Waste}

Medical waste includes biohazardous waste (e.g., blood and blood-contaminated materials), "sharps" waste (e.g., needles), and other waste produced in research relevant to the diagnosis, treatment, or immunization of human beings or animals or in the production of biological products used in medicine. In California, the state's Medical Waste Management Act $^{31}$ contains requirements designed to ensure the proper storage, treatment, and disposal of medical waste. The state program is administered by DHS.

The Laboratory generates medical waste at about 100 different locations distributed over 12 buildings, including four off-site buildings. The Life Sciences programs, including the Human Genome project, are the primary generators of medical waste. Berkeley Lab does not treat any medical waste; treatment of medical waste is performed at off-site vendor facilities. Berkeley Lab ships medical waste off site for treatment through incineration or steam sterilization. The majority of the waste is treated via steam sterilization before disposal at a landfill.

Under the state's program, Berkeley Lab is considered a large-quantity generator because it generates more than 91 kilograms ( 200 pounds) of medical waste each month. The Laboratory completed its annual registration renewal in November.

DHS conducted an inspection of the program in April, reviewing program documentation (including tracking records) and visiting several medical waste generation sites. This inspection resulted in three minor violations, one of which was contested by Berkeley Lab. The Laboratory submitted a written reply to DHS regarding this violation and has yet to receive a response. DHS has not assessed any fines or penalties against Berkeley Lab. Because a response has not been received from DHS, Berkeley Lab recorded two minor violations for the DHS inspection. See Table 3-2.

\section{$\$ 3.20$ 4. Underground Storage Tanks}

In the early 1980s, California started addressing the serious threat of groundwater contamination from leaking underground storage tanks (USTs) through a rigorous regulatory and remediation program. ${ }^{32}$ The state requirements for USTs containing hazardous materials include permitting, construction design, monitoring, record-keeping, inspection, accidental releases, financial responsibility, and tank closure. The state's program satisfies the provisions of RCRA. ${ }^{33}$ The City of Berkeley is the local administering agency for UST regulations that apply to Berkeley Lab. 


\begin{tabular}{|c|c|c|c|c|c|}
\hline $\begin{array}{l}\text { Registration } \\
\text { tank ID \# }\end{array}$ & $\begin{array}{l}\text { LBNL } \\
\text { building \# }\end{array}$ & $\begin{array}{l}\text { Stored } \\
\text { material }\end{array}$ & $\begin{array}{l}\text { Capacity liters } \\
\text { (gallons) }\end{array}$ & Construction & $\begin{array}{c}\text { Year } \\
\text { installed }\end{array}$ \\
\hline \multicolumn{6}{|c|}{ Fiberglass tanks, double-walled } \\
\hline $2-1$ & 2 & Diesel & $15,200(4,000)$ & Fiberglass & 1988 \\
\hline $2-2$ & 2 & Diesel & $3,800(1,000)$ & Fiberglass & 1988 \\
\hline $85-1$ & 85 & Diesel & $9,500(2,500)$ & Fiberglass & 1995 \\
\hline \multicolumn{6}{|c|}{ Double-walled steel with fiberglass plastic corrosion protection } \\
\hline $55-1$ & 55 & Diesel & $3,800(1,000)$ & Glasteel & 1986 \\
\hline $66-1$ & 66 & Diesel & $15,200(4,000)$ & Glasteel & 1987 \\
\hline $66-2$ & 66 & Diesel & $7,600(2,000)$ & Glasteel & 1987 \\
\hline $76-1$ & 76 & $\begin{array}{l}\text { Unleaded } \\
\text { gasoline }\end{array}$ & $\begin{array}{c}38,000 \\
(10,000)\end{array}$ & Glasteel & 1990 \\
\hline $76-2$ & 76 & Diesel & $\begin{array}{c}38,000 \\
(10,000)\end{array}$ & Glasteel & 1990 \\
\hline
\end{tabular}

At the end of 1998, eight permitted USTs remained at the Laboratory. See Table 3-7. The tanks contain either diesel fuel or unleaded gasoline. All tanks are double-walled and meet regulatory standards for construction, monitoring, leak containment, and design of operating tanks. The Laboratory has removed a total of seven tanks from the site since 1993.

\section{E. Pollution Prevention and Waste Minimization}

\section{\$3.21 1. Executive Order 13301 (Greening the Government through Waste Prevention, Recycling, and Federal Acquisition)}

Executive Order 13301 (Greening the Government through Waste Prevention, Recycling, and Federal Acquisition) ${ }^{34}$ replaces Executive Order 12873 (Federal Acquisition, Recycling, and Waste Prevention). Like its precursor, Executive Order 13301 seeks to integrate recycled materials into the procurement and acquisition process. Identified categories of products include:

- Paper and paper products;

- Vehicular products;

- Construction products;

- Transportation products;

- Park and recreation products;

- Landscaping products; and

- Nonpaper office products.

In procuring these items, all federal agencies must, by December 31, 2004, buy only EPA-listed items with certain contents of recycled materials.

Berkeley Lab has had an affirmative procurement program since 1992. The Laboratory's buyers search for products made from recycled materials and work with 
other federal facilities to enhance their power to purchase environmentally sound products. The Laboratory has implemented a "stepped" program to ensure that, by December 31, 2004, only EPA-listed products produced from recycled materials will be purchased as long as these materials are available at reasonable cost and compatible with the Laboratory's operating needs.

\section{$\$ 3.22$ 2. Hazardous Waste Source Reduction and Management Review Act}

The California State Legislature passed the Hazardous Waste Source Reduction and Management Review Act ${ }^{35}$ in 1989. With an emphasis on minimizing waste and preventing pollution, the Act has the following goals:

- To reduce hazardous waste at its source;

- To encourage recycling wherever source reduction is not feasible or practicable;

- To manage hazardous waste in an environmentally safe manner and minimize present and future threats to health and the environment if it is not feasible to reduce or recycle; and

- To document hazardous waste management information and make that information available to state and local government.

Berkeley Lab maintains and certifies a two-part report for compliance with this Act: the Source Reduction Evaluation Review Plan and Plan Summary ${ }^{36}$ and the Hazardous Waste Management Report Summary. ${ }^{37}$

\section{\$3.23 3. Pollution Prevention Act of $\mathbf{1 9 9 0}$}

The Pollution Prevention Act ${ }^{38}$ of 1990 declares that source reduction is a national policy and directs US/EPA to study and encourage source reduction policies. Berkeley Lab's levels of pollution remain below the de minimis numbers identified in the Act and are not subject to its reporting requirements.

\section{F. Water Quality}

\section{§3.24 1. Clean Water Act}

The Clean Water Act (CWA) ${ }^{39}$ regulates the discharge of pollutants to the waters of the United States from both point and nonpoint sources using various means, including development of pollutant discharge standards and limitations and a permit and licensing system to enforce such standards. California is authorized by US/EPA to administer the principal components of the federal water quality management program.

Additionally, the Porter-Cologne Water Quality Control Act ${ }^{40}$ established a comprehensive statewide system for regulating water use in California. This 1969 Act provides for the three-tiered system that is still in use today: the State Water Resources Control Board (SWRCB), the nine Regional Water Quality Control Boards (RWQCB), and local governments. 
For Berkeley Lab, the regional authority is the San Francisco Bay RWQCB. The local authorities are the Cities of Berkeley and Oakland, for stormwater, and the East Bay Municipal Utility District (EBMUD), for drinking water supply and wastewater.

\section{$\S 3.25$ a. Wastewater}

The Laboratory has four wastewater discharge permits ${ }^{41}$ issued by EBMUD for the following activities:

- General sitewide wastewater discharge;

- Discharge from treatment unit at metal finishing operations in Building 25;

- Discharge from treatment unit at metal finishing operations in Building 77; and

- Sitewide discharge of treated groundwater from hydraugers and wells.

Permits are renewed annually, except for the treated groundwater permit, which has a two-year duration. The permits incorporate standard terms and conditions as well as individual discharge limits, provisions, and monitoring and reporting requirements. Under each permit, Berkeley Lab submits periodic self-monitoring reports. The number of reports and their timing depend on the individual permit. For the results of the Laboratory's annual self-monitoring program, see chapter 7.

EBMUD also inspects the Laboratory's sanitary sewer discharge activities without prior notice. The agency conducted inspections on ten separate occasions throughout the year. Table 3-2 (see \$3.4) contains these dates.

A discharge sample collected by Berkeley Lab from the Building 77 Fixed Treatment Unit (FTU) on July 9 was determined to contain $10 \mathrm{mg} / \mathrm{L}$ of chromium, which exceeds the maximum permit limit $(2.77 \mathrm{mg} / \mathrm{L}$ daily and $1.71 \mathrm{mg} / \mathrm{L}$ monthly average concentration). On confirming the analytical results, the Laboratory notified EBMUD, and an incident investigation was initiated on July 21 . Berkeley Lab received a violation notice from EBMUD on August 8 for this self-reported chromium discharge.

Although the ongoing investigation implemented interim measures to control chromium discharges from the treatment unit, a subsequent discharge sample collected by EBMUD on August 17 was found to contain $7.07 \mathrm{mg} / \mathrm{L}$ of chromium. On September 16, EBMUD issued a second violation notice, and Berkeley Lab shut down the treatment unit pending further review. A series of corrective actions was identified and is being implemented.

Because the two chromium violations exceeded both daily maximum and monthly average wastewater discharge permit limits and occurred in close proximity in time, the Building 77 FTU was characterized as in "significant noncompliance" with these limits. This characterization was noted in EBMUD's Annual Report and published in the Oakland Tribune on March 17, 1999. For sampling results from the Building 77 FTU, see volume II.

The wastewater discharge permits for Buildings 25 and 77 require that the facility maintain a Toxic Organics Management Plan $^{42}$ (TOMP). Each TOMP outlines facility management practices designed to minimize the release of toxic organics to the sanitary sewers or external environment. 
An Accidental Spill Prevention and Containment $\operatorname{Plan}^{43}$ (ASPCP) is required under the terms of the wastewater discharge permits. Specifically, Berkeley Lab must maintain this plan for areas where spills have the greatest potential to occur. Berkeley Lab has prepared operation-specific plans for photoprocessing activity, Building 25, Building 77 , the motor pool at Building 76, and the fixed treatment units at Buildings 2 and 70A. EBMUD requires that these documents be maintained on file in the relevant areas and that essential emergency information be posted. The plans need not be submitted to the agency.

The TOMP and ASPCP for Building 77 have been combined ${ }^{44}$ and will be combined for Building 25 to reduce duplication of information.

\section{$\$ 3.26$ b. Stormwater}

Berkeley Lab's stormwater releases are permitted under the California-wide General Permit for Stormwater Discharges Associated With Industrial Activity. ${ }^{45}$ The General Permit is issued by the State Water Resources Control Board but administered and enforced by the Regional Water Quality Control Board and the City of Berkeley. Under this permit, the Laboratory has implemented a Stormwater Pollution Prevention Plan ${ }^{46}$ and a Stormwater Monitoring Program. ${ }^{47}$ Together, these documents represent the Laboratory's plan and procedures for identifying, monitoring, and reducing pollutants in its stormwater discharges. The Stormwater Pollution Prevention Plan was revised and updated in 1998.

The General Permit requires submission of an annual report on stormwater activities by July 1 . Berkeley Lab transmitted its annual report to the Regional Water Quality Control Board and the City of Berkeley. ${ }^{48}$ No regulatory concerns were raised by either agency regarding the annual report. For detailed discussion of stormwater results for 1998, see §5.6. The City of Berkeley has the authority to inspect Berkeley Lab's stormwater program. No inspections of this program took place in 1998.

A minor environmental incident occurred on April 20 when 610 liters (160 gallons) of washwater generated from the cleaning process of the old Hazardous Waste Handling Facility at Building 75 were incorrectly disposed to the stormwater drain. The washwater had been analyzed and approved for disposal to the sanitary sewer, but it was inadvertently released to the storm drain. The City of Berkeley Toxics Management Division was notified of the release on April 21. This minor release presented no health risk to the public or danger to the environment and did not approach any CERCLA, EPCRA, Porter-Cologne, or Clean Water Act reporting thresholds.

\section{\$3.27 c. Aboveground Storage Tanks}

Aboveground storage tanks (ASTs) also fall under the authority of the Clean Water Act. ${ }^{49}$ The Clean Water Act and the state's Aboveground Petroleum Storage Act ${ }^{50}$ outline the regulatory requirements for this type of tank. Nonpetroleum (i.e., chemical or hazardous) ASTs consist of FTU tank, drum storage at Waste Accumulation Areas (WAA), and drum storage at product distribution areas. FTU tanks are inspected each operating day by operators of the FTU. WAAs are inspected weekly by EH\&S staff. 
Product distribution areas contain petroleum and nonpetroleum drums. Both types of drums are inspected during routine petroleum drum inspections.

Aboveground storage tanks are provided with secondary containment or spill kits to capture any potential spills. No ASTs were identified during the year that needed new or upgraded secondary containment.

Figure 3-3 shows the locations of the ASTs that contain petroleum hydrocarbon products.

\section{$\$ 3.28$ 2. Safe Drinking Water Act}

The Safe Drinking Water $\mathrm{Act}^{51}$ established requirements to protect underground sources of drinking water and set primary drinking water standards for public water systems. Berkeley Lab has no drinking water wells on site. The drinking water provided to the site comes from the East Bay Municipal Utility District (EBMUD) supply and distribution system. Berkeley Lab has taken measures to protect its drinking water supply distribution system by installing backflow prevention devices on main supply lines throughout the site.

Between February and April 1998, EBMUD switched from chlorine to chloramine for disinfection of the drinking water supply. Although chloramine improves the water

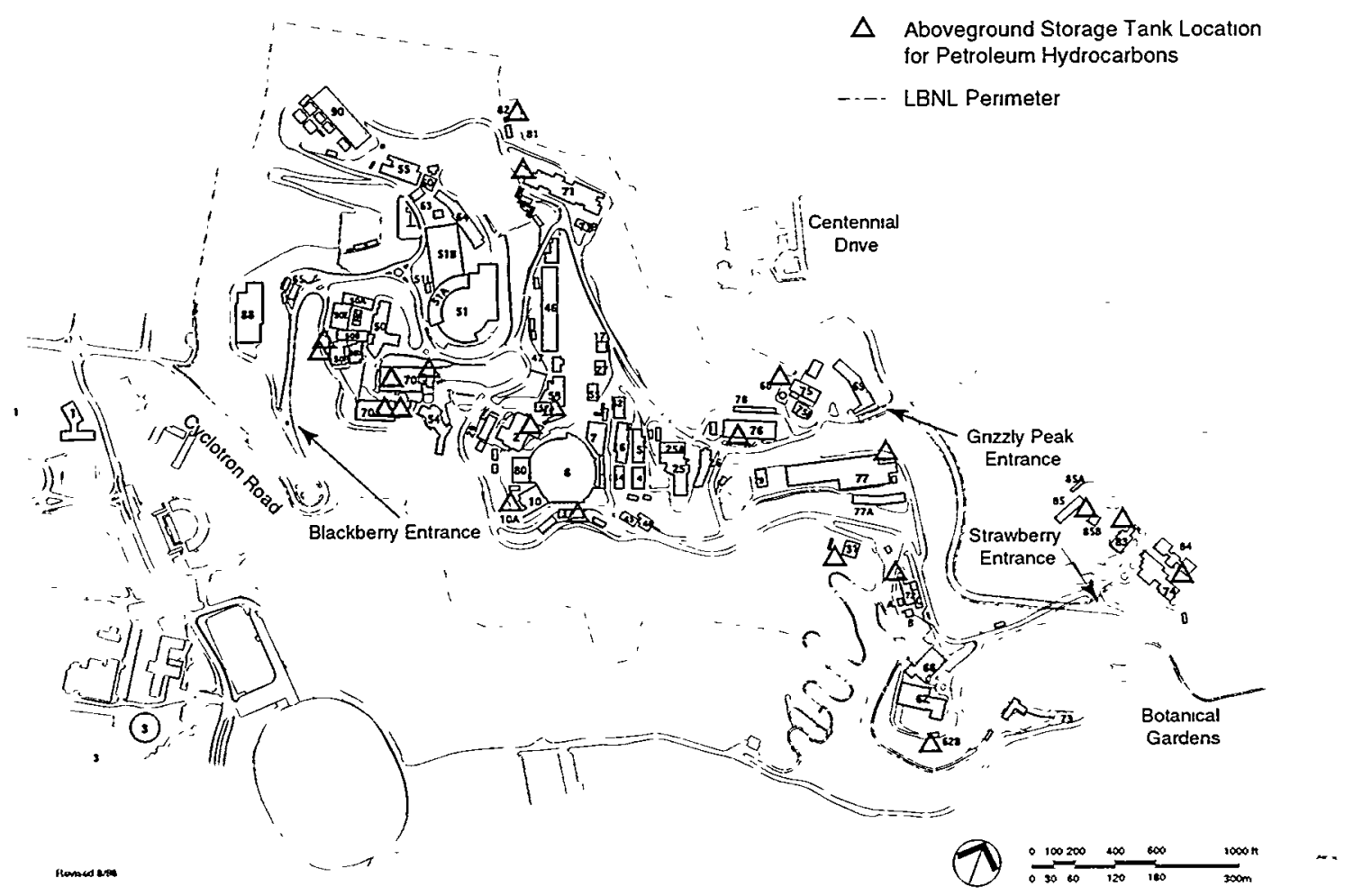

Figure 3-3 Aboveground Storage Tank Locations 
supply for human consumption, it is toxic to fish and other aquatic organisms. Berkeley Lab responded to this threat in two ways:

- To prevent damage to laboratory research involving such organisms, the Industrial Hygiene Group worked with researchers to institute measures to neutralize the chloramine and provide water in which these organisms can safely exist.

- To prevent damage to organisms living in neighboring creeks, the Industrial Hygiene and Environmental Protection Groups worked with EBMUD to prevent drinking water from being discharged to the Laboratory's storm drains. For water line breaks and legally mandated testing and flushing of fire hydrants, these groups worked with the Facilities and Fire Departments to implement methods of neutralizing chloramine in the water before it reaches a storm drain.

\section{PROGRAM PERFORMANCE}

\section{$\$ 3.29$ A. Overview}

Since 1994, Berkeley Lab, DOE, and Berkeley Lab's managing partner, the University of California Office of the President, have had a system to measure the effectiveness of the Laboratory's environmental programs. These performance measures have been an annual requirement integrated directly into the operating contract for the site.

Measures were categorized into two types: process and outcome. Process can be thought of as the foundation for building programs. Outcome is the ultimate product of a program's performance. The remainder of this chapter outlines each type of measure and presents the most current results on their effectiveness. ${ }^{52}$

\section{$\$ 3.30$ B. Process Performance Measures}

Process performance measures evaluate how well Berkeley Lab has implemented DOE's integrated safety management system. This system examines the Laboratory's overall environment, health, and safety performance.

The performance period for these process measures runs from July 1 through the following June 30. For fiscal year 1998, the Laboratory achieved a "good" rating for its processes in waste minimization, pollution prevention, and protection of the environment.

\section{$\$ 3.31$ C. Outcome Performance Measures}

Outcome performance measures focus on bottom-line results during a specified period. Three measures track environmental performance by Berkeley Lab:

- Radiation Protection of the Public and the Environment;

- Tracking Environmental Incidents; and

- Waste Reduction and Recycling.

As is done with the process measures, a set of assumptions and criteria are jointly established by Berkeley Lab, DOE, and UCOP that lead to a rating on a gradient scale 
(i.e., "good," "excellent," "outstanding") when the measure is assessed. Unlike the process performance measures, the outcome measures are subject to a performance period that runs from January 1 through December 31 . The following sections contain a brief discussion of each measure.

\section{§3.32 1. Radiation Protection of Public and Environment}

The goal of this measure is to ensure that radiation doses to the maximally exposed individual member of the public and radiological emissions to the environment from Berkeley Lab operations remain well below applicable regulatory limits. This measure considers the impact from penetrating radiation and dispersible radionuclide sources. Supporting information used to derive the measure's results comes from established Laboratory environmental monitoring activities. Figures 3-4 through 3-6 display the quarterly results for 1998 from each of these media. Together, these indicators received a performance ranking of "excellent."

\section{$\$ 3.33$ 2. Tracking Environmental Incidents}

Environmental incidents considered by this measure are either (a) violations resulting from regulatory inspections or regulatory reporting or (b) reportable occurrences of environmental releases exceeding regulatory or permitted levels. Under these criteria, Berkeley Lab had five environmental incidents in 1998. DOE, UC, and Berkeley Lab agreed that three of the five incidents were minor and that the three minor incidents would be given a weighting factor for calculating a score for this measure. The annual score for this measure was "excellent."

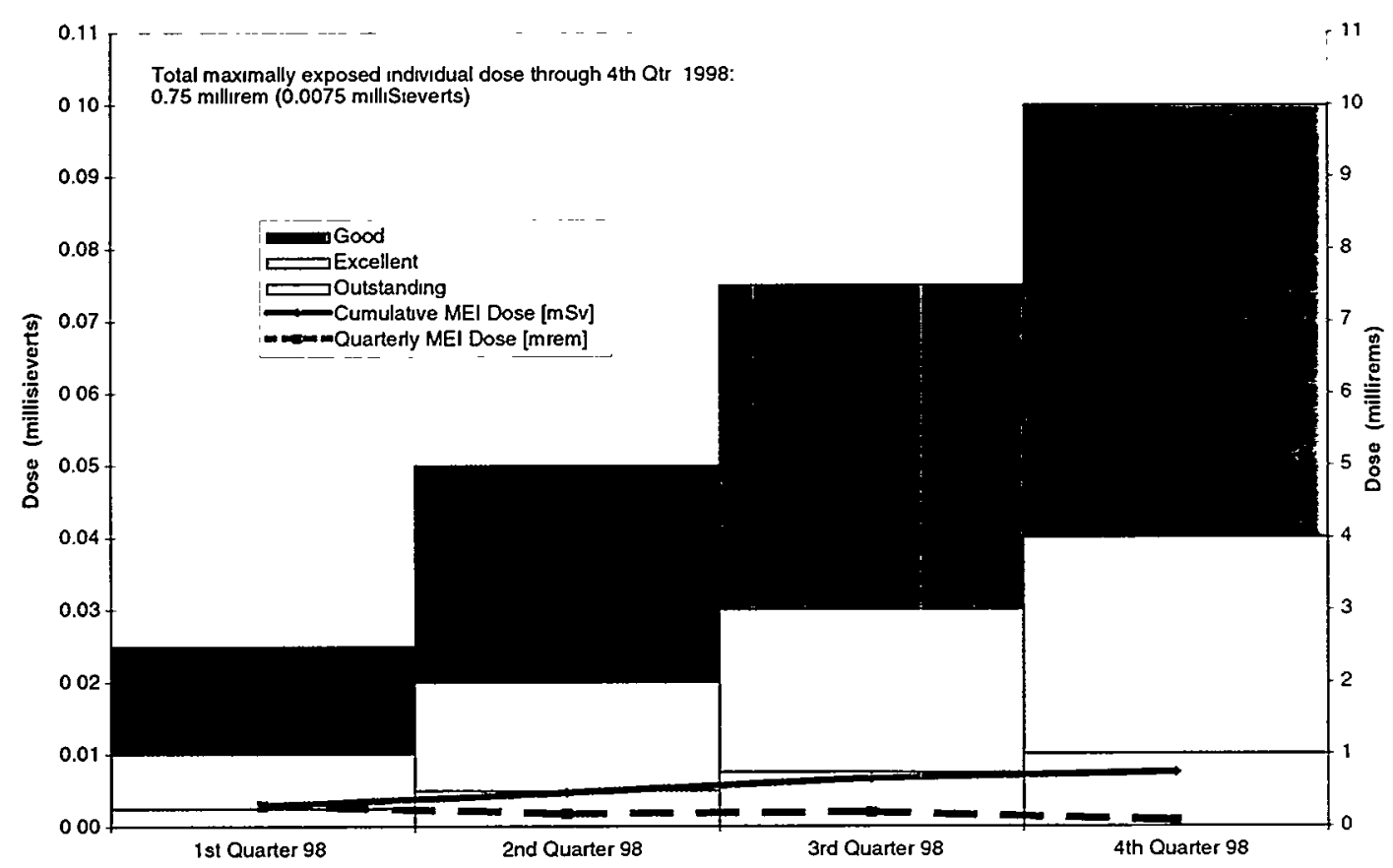

Figure 3-4 Quarterly Radiation Dose to Public 


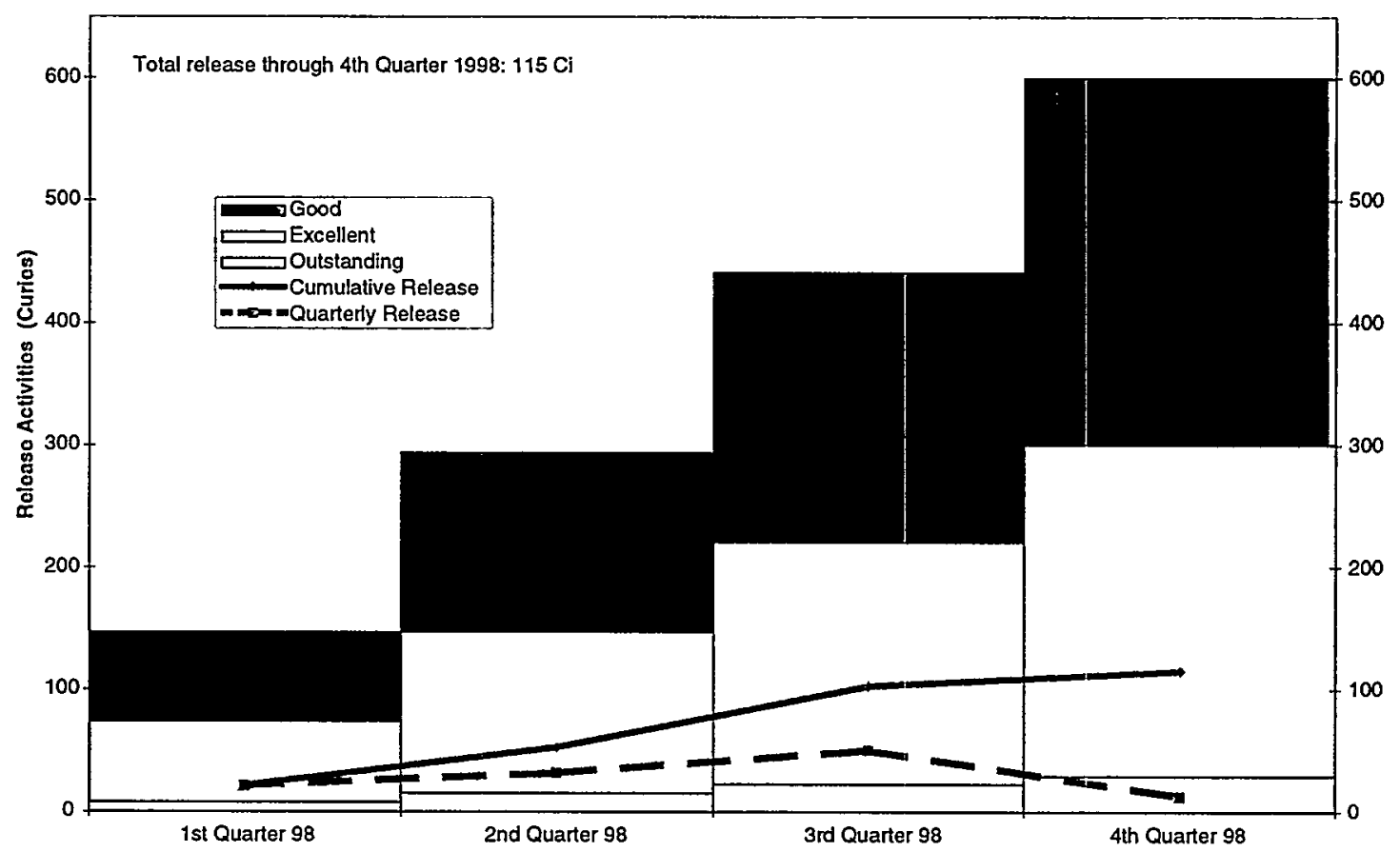

Figure 3-5 Quarterly Radiological Emissions to Air

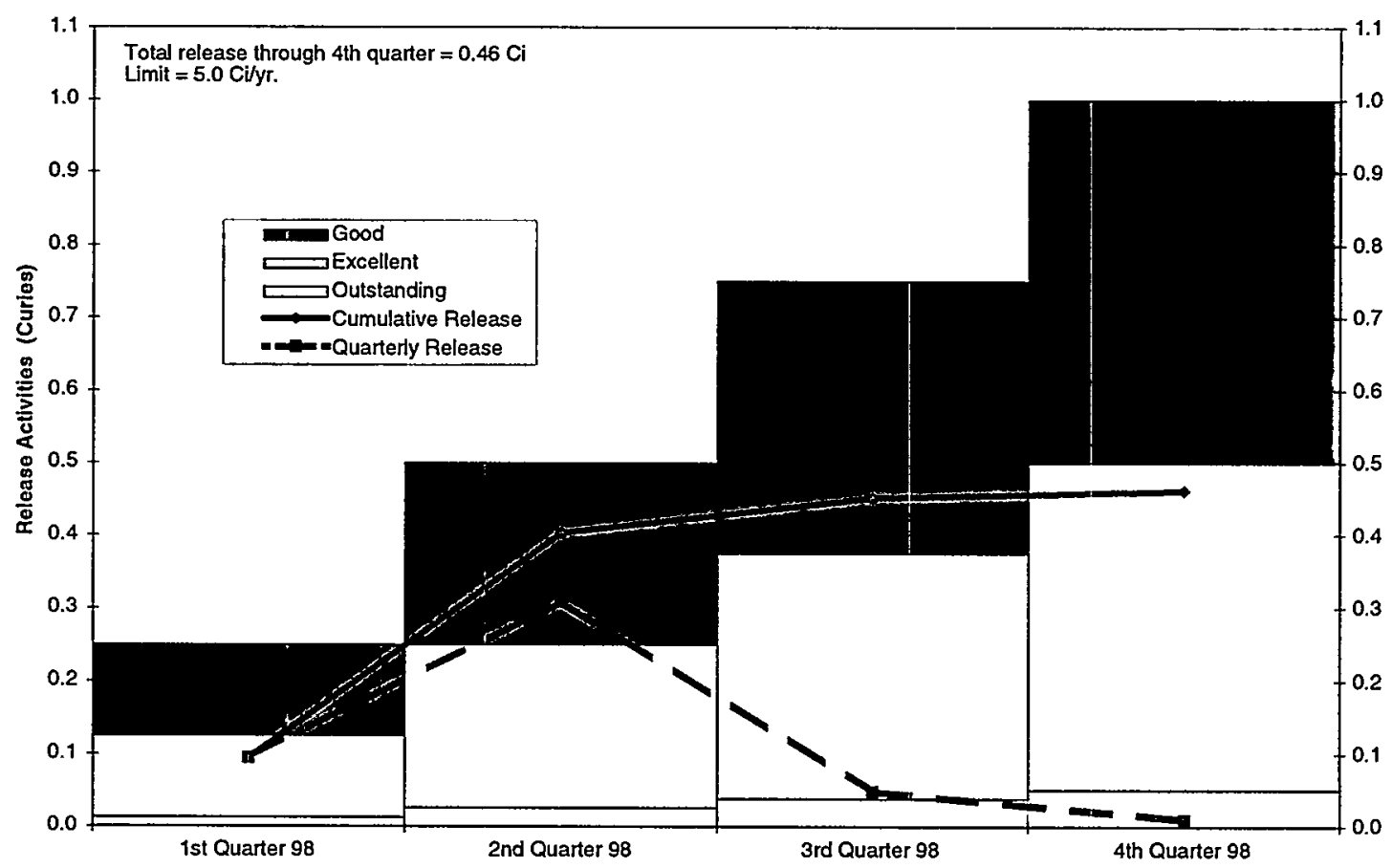

Figure 3-6 Quarterly Radiological Effluent Discharged to Sanitary Sewer 


\section{$\$ 3.34 \quad 3 . \quad$ Waste Reduction and Recycling}

This measure tracks the progress of Berkeley Lab toward the pollution prevention goals that DOE has established for the beginning of 2000. The routine waste streams targeted by this measure are:

- Nonhazardous or sanitary waste;

- Hazardous waste;

- Low-level mixed waste (waste that contains both hazardous and radioactive components); and

- Low-level radioactive waste.

The overall goal of the measure is a $33 \%$ reduction in the first waste stream and a $50 \%$ reduction for the last three waste streams by the December 31, 1999, deadline, using 1993 as the baseline year for comparison. Adjustments in the baseline-year levels can be made, however, to account for significant program growth. Each waste stream is tracked separately. Figures 3-7 through 3-10 summarize the status of these waste streams. Overall, Berkeley Lab achieved a score that qualifies for an "outstanding" rating, based on the combined waste reduction performance in all four categories.

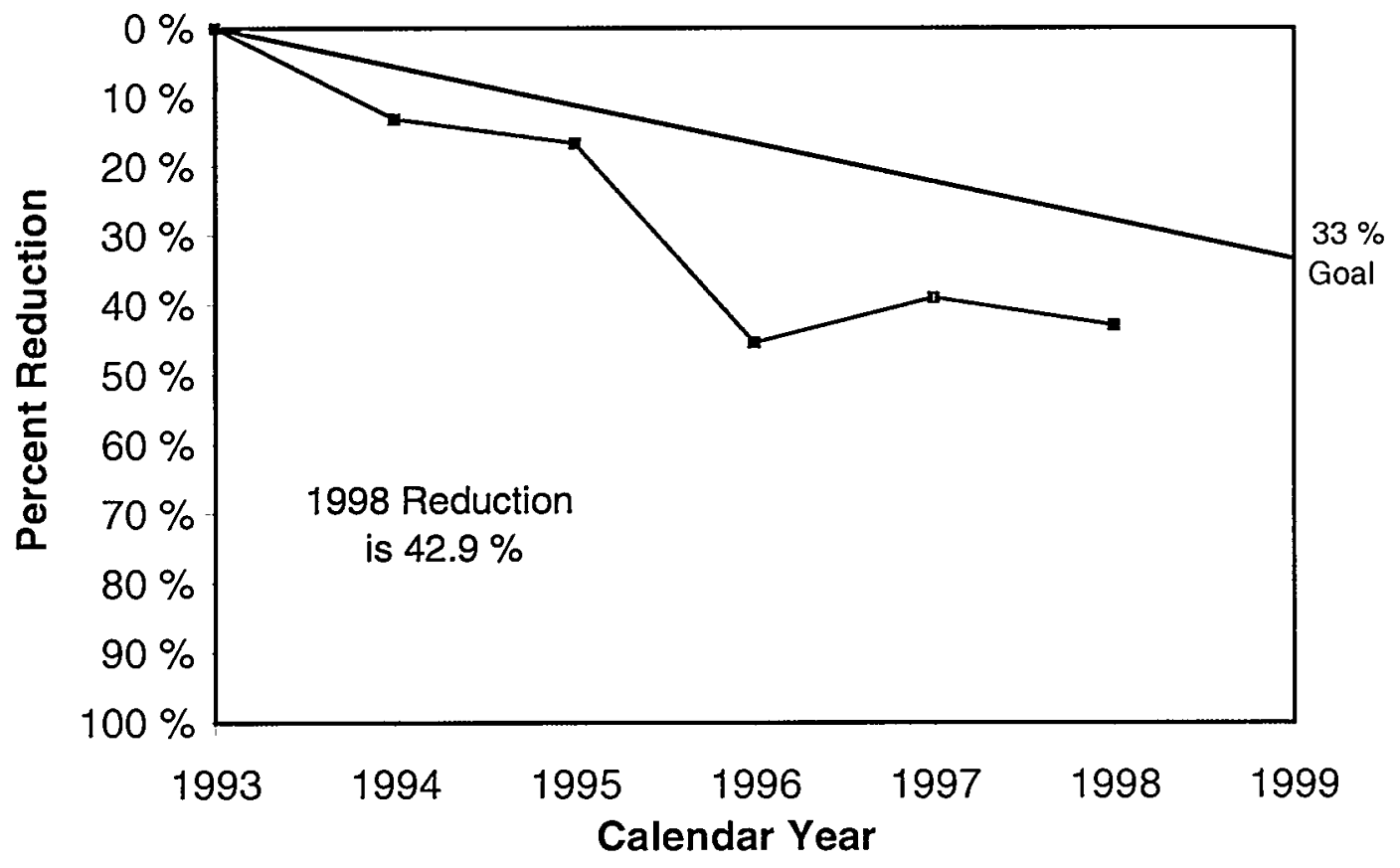

Figure 3-7 Trends in Reducing Routine Nonhazardous or Sanitary Waste 


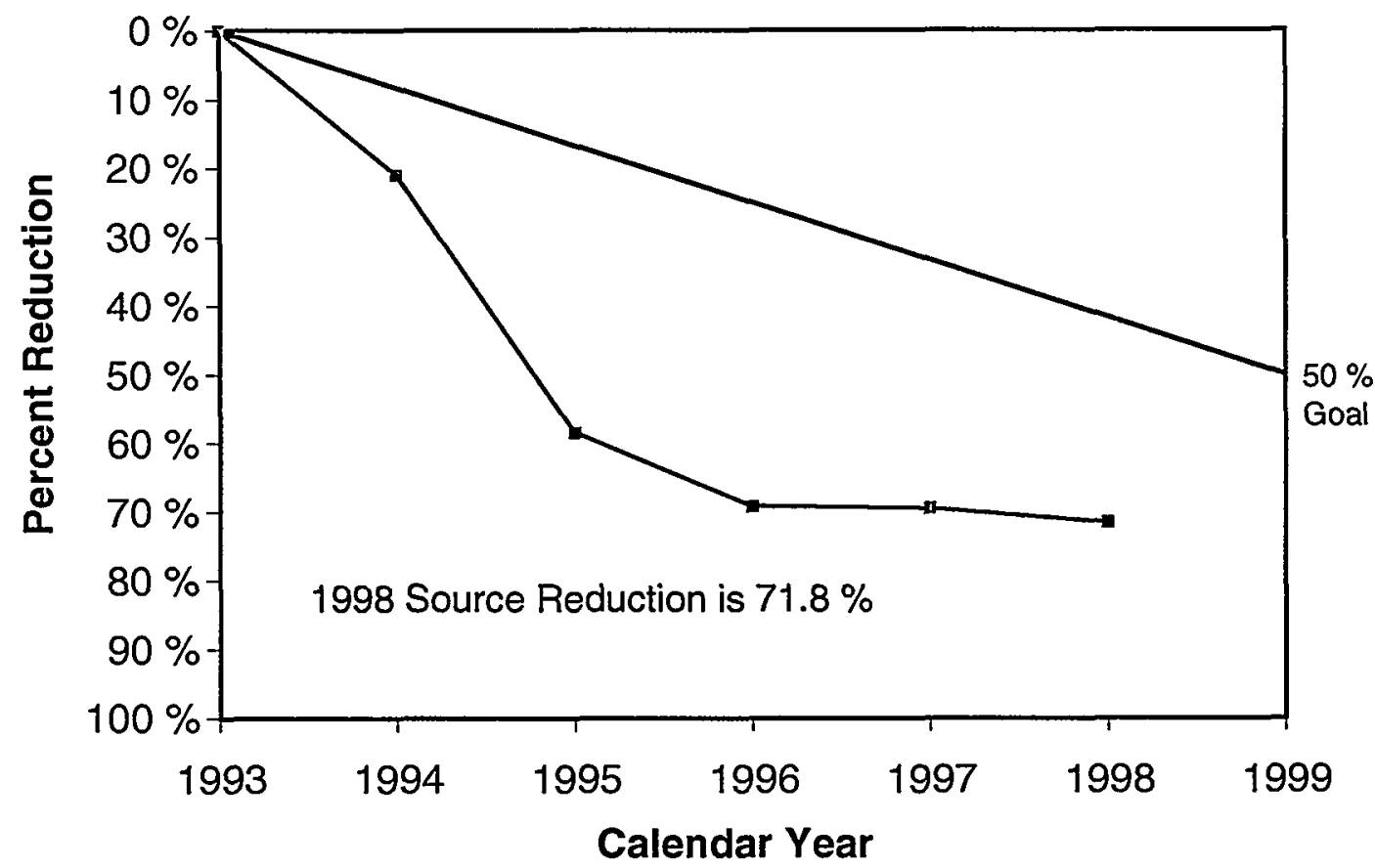

Figure 3-8 Trends in Reducing Routine Hazardous Waste

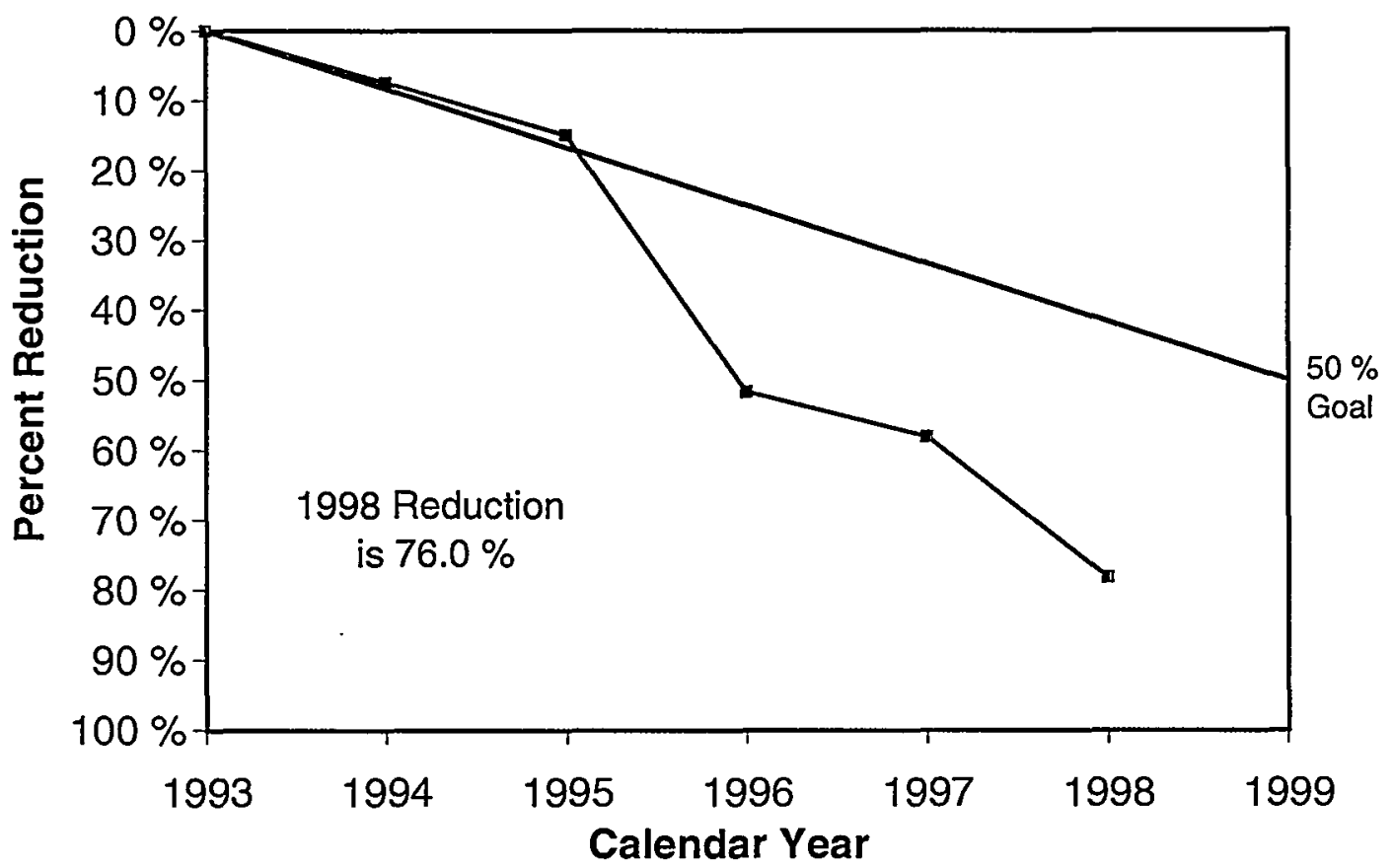

Figure 3-9 Trends in Reducing Routine Mixed Waste 


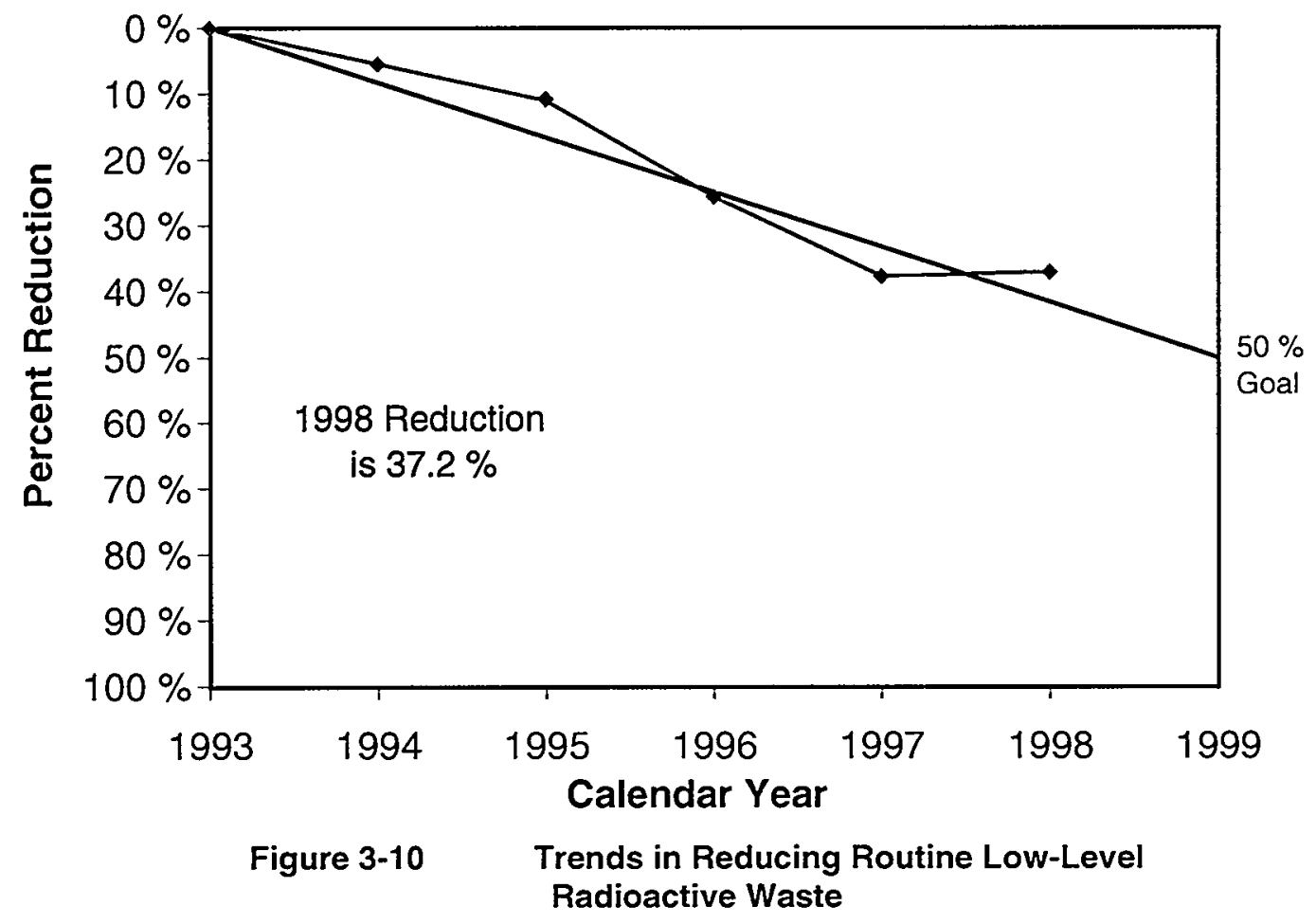




\section{4 \\ Air Quality}

I. BACKGROUND $\$ 4.1$

II. EXHAUST SYSTEM SAMPLING RESULTS \$4.2

Table 4-1: Most Significant Radionuclides Used During 1998

Table 4-2: US/EPA-Approved NESHAPs Compliance Strategy

Table 4-3: NESHAPs Building Exhaust Sampling and Monitoring Profile

Table 4-4: Summary of Radiological Air Emissions Released During 1998

Figure 4-1: Trends in Annual Tritium Releases from NTLF III. AMBIENT AIR MONITORING RESULTS
A. Tritium $\$ 4.3$

Figure 4-2: Ambient Air Monitoring Network Sampling Locations

Table 4-5: Summary of Ambient Tritium Sampling

B. Gross Alpha/Beta $\$ 4.4$

Table 4-6: Gross Alpha and Beta Sampling Results from Ambient Air Monitoring Network

\section{$\$ 4.1 \quad$ I. BACKGROUND}

Berkeley Lab's air monitoring program is designed to meet the following set of requirements:

- 40 CFR Part 61, Subpart H (NESHAPs) ${ }^{1}$;

- DOE Order 5400.1 (General Environmental Protection Program) ${ }^{2}$; and

- DOE Order 5400.5 (Radiation Protection of the Public and the Environment). ${ }^{3}$

NESHAPs and DOE Order 5400.5 authorize monitoring requirements for radiological air emissions, while DOE Order 5400.1 includes additional requirements for nonradiological air emissions.

Under present requirements, the Berkeley Lab air quality program measures only radiological components. Estimates of nonradiological air emissions use alternative methodologies (e.g., engineering calculations, record-keeping, and dose/risk modeling) to 
satisfy regulatory requirements. The comprehensive Environmental Monitoring Plan ${ }^{4}$ describes the basis and current scope of the air monitoring program at the Laboratory.

The air monitoring program consists of two separate elements: exhaust emissions monitoring and ambient air surveillance. Exhaust emissions monitoring measures airborne contaminants in building exhaust streams. Ambient air surveillance measures air contaminants in the outdoor environment.

Ambient air surveillance results alone cannot distinguish between Berkeley Lab, non-Berkeley Lab, and natural background emission sources. When combined with exhaust emissions monitoring results and local meteorological information, however, ambient air surveillance results can help characterize the impact of Laboratory activities on the surrounding environment. The number and placement of monitoring stations, as well as the parameters monitored and their frequency, are routinely reviewed to account for changes in Laboratory operations or external requirements.

\section{\$4.2 II. EXHAUST SYSTEM SAMPLING RESULTS}

Berkeley Lab uses various radionuclides in its radiochemical and biomedical research programs. In addition, radioactive materials are generated from the operations of charged particle accelerators. Radionuclide releases from on-site building exhaust systems are usually in the form of vapor or gas. Releases in solid form as particulate matter are the least common form.

Table 4-1 contains the names and decay characteristics of the most significant radionuclides used at Berkeley Lab. Radioactive gases produced by accelerator operations are mainly short-lived radionuclides, such as carbon-11, nitrogen-13, oxygen-15, and argon-41.

The NESHAPs regulations require source measurement if the potential dose, or exposure over time, from emissions exceeds $1.0 \times 10^{-3} \mathrm{mSv} / \mathrm{yr}(0.1 \mathrm{mrem} / \mathrm{yr}){ }^{1}$ As discussed in \$3.7, Berkeley Lab uses a comprehensive tiered strategy approved by US/EPA to satisfy this requirement. See Table 4-2. This strategy involves three distinct levels of assessment:

- Real-time monitoring. Sophisticated monitoring systems that provide measurements in real time.

- Continuous sampling. In-line instrumentation for collection of time-integrated air samples that undergo laboratory analysis following US/EPA-approved protocols.

- Administrative controls. Strict administrative limits on radionuclide inventories and emission estimates.

The number and location of sources under each assessment category change in response to the research at Berkeley Lab. All but one source are considered "small sources" of emissions under NESHAPs. The vast majority fall into compliance assessment Category V, which requires no monitoring. The 90 sources in this group adhere to strict inventory limits specified in individual work authorizations. Twenty-three locations use continuous sampling, including the only compliance Category I source on site (the tritium stack at Building 75). Three locations have more rigorous real-time 
Table 4-1 Most Significant Radionuclides Used During 1998*

\begin{tabular}{lcll}
\hline $\begin{array}{c}\text { Nuclide name } \\
\text { (atomic number) }\end{array}$ & Symbol & \multicolumn{1}{c}{$\begin{array}{c}\text { Principal radiation } \\
\text { types }\end{array}$} & Half-life \\
\hline Carbon (6) & ${ }^{11} \mathrm{C}$ & positron/gamma & 20.5 minutes \\
& ${ }^{14} \mathrm{C}$ & beta & 5730 years \\
Fluorine (9) & $18 \mathrm{~F}$ & positron/gamma & 109.7 minutes \\
Hydrogen/Tritium (1) & ${ }^{3} \mathrm{H}$ & beta & 12.28 years \\
lodine (53) & 123 I & gamma & 13.1 days \\
& $125 \mid$ & beta & 60.14 days \\
Nitrogen (7) & 131 I & gamma & 8.04 days \\
Oxygen (8) & $13 \mathrm{~N}$ & positron/gamma & 9.97 minutes \\
& $14 \mathrm{O}$ & positron/gamma & 71 seconds \\
& $15 \mathrm{O}$ & positron/gamma & 122 seconds \\
\hline
\end{tabular}

"For a complete list of radionuclides evaluated under NESHAPs regulations, see Radionuclide Air Emission Annual Report for 1998, found on Berkeley Lab's EH\&S Web site at http://www.lbl.gov/ ehs/html/env_protection.htm.

monitoring systems to estimate emissions with radionuclide half-lives that are less than 100 hours. Table 4-3 lists the breakdown of source assessment by category for the reporting year.

The stack monitoring program analyzed emission samples for five radiological parameters in 1998: gross alpha, gross beta, carbon-14, iodine-125, and tritium. As in past years, tritium in the form of tritiated water vapor was the predominant radionuclide emitted from Berkeley Lab activities. Tritium emissions totaling $4.26 \times 10^{12} \mathrm{~Bq}(115 \mathrm{Ci})$ were measured during the year, with nearly all tritium emitted from the National Tritium Labeling Facility's (NTLF) exhaust stacks. Table $4-4$ provides the list of the most

Table 4-2 US/EPA-Approved NESHAPs Compliance Strategy

\begin{tabular}{|c|c|c|}
\hline $\begin{array}{c}\text { Compliance } \\
\text { category }\end{array}$ & $\begin{array}{l}\text { Annual effective } \\
\text { dose equivalent } \\
\text { (mSv/yr) }\end{array}$ & Sampling/monitoring strategy \\
\hline Noncompliant & AEDE $>0.1$ & $\begin{array}{l}\text { Reduce or relocate source term and reevaluate } \\
\text { before authorization. }\end{array}$ \\
\hline 1 & $0.1>$ AEDE $>0.001$ & $\begin{array}{l}\text { Continuous sampling with telemetry to central } \\
\text { computer for half-life less than } 100 \text { hours and } \\
\text { weekly analysis for half-life greater than } 100 \\
\text { hours. (US/EPA approval required to construct } \\
\text { or modify.) }\end{array}$ \\
\hline$\|$ & $0.001>$ AEDE $>0.0005$ & Continuous sampling with weekly analysis. \\
\hline III & $0.0005>$ AEDE $>0.0001$ & Continuous sampling with monthly analysis. \\
\hline IV & $0.0001>$ AEDE $>0.00001$ & Sampled annually during project activity. \\
\hline V & $0.00001>$ AEDE & $\begin{array}{l}\text { No monitoring required. Inventory controlled by } \\
\text { administrative methods (Radiation Work } \\
\text { Authorization/Permit). }\end{array}$ \\
\hline
\end{tabular}


Table 4-3 NESHAPs Building Exhaust Sampling and Monitoring Profile

\begin{tabular}{lll}
\hline $\begin{array}{c}\text { Monitoring } \\
\text { type }\end{array}$ & \multicolumn{1}{c}{ Method } & \multicolumn{1}{c}{ Location } \\
\hline Real-time & Real-time monitoring of ${ }^{11} \mathrm{C},{ }^{13} \mathrm{~N}$, and ${ }^{15} \mathrm{O}$ & Bldg. 88 accelerator exhaust \\
& Real-time monitoring of ${ }^{11} \mathrm{C},{ }^{13} \mathrm{~N},{ }^{15} \mathrm{O}$, and & $\begin{array}{l}\text { Bldg. 56 Biomedical Isotope Facility } \\
\text { accelerator exhaust (2 locations) }\end{array}$ \\
& ${ }^{18} \mathrm{~F}$ & 8 locations \\
Continuous & Sampling with weekly analysis & 15 locations \\
& Sampling with monthly analysis & 90 locations \\
No & Inventory (administrative) control & \\
monitoring & & \\
\hline
\end{tabular}

significant radionuclide air emissions from site activities for the year. For information on the projected dose from all radionuclide emissions, see chapter 10.

Tritium emissions rose in 1998 from the previous year because of a combination of increased research activity at the NTLF and an unplanned release of $1.30 \times 10^{12} \mathrm{~Bq}$ (35 Ci) on July 24. In spite of this increase, emissions of tritium are still well below levels from the late 1980s and well below regulatory levels of concern. The most recent fiveyear average of $2.43 \times 10^{12} \mathrm{~Bq}(65.8 \mathrm{Ci})$ is about $12 \%$ of the 1988 emissions level of $21.5 \times 10^{12} \mathrm{~Bq}(580 \mathrm{Ci})$. A series of engineering and administrative controls enacted in the early 1990s reduced and maintained emissions to their current level. See Figure 4-1. Before the July incident, the NTLF did not have an unplanned release greater than $1.10 \times 10^{12} \mathrm{~Bq}(30 \mathrm{Ci})$ in more than four years. The release was much less than the EPA reportable quantity of $3.70 \times 10^{12} \mathrm{~Bq}(100 \mathrm{Ci})$ for tritium..$^{5}$ For details on the July release, see $\$ 3.7$.

\begin{tabular}{lcc} 
Table 4-4 & \multicolumn{2}{c}{$\begin{array}{c}\text { Summary of Radiological Air Emissions } \\
\text { Released During 1998* }\end{array}$} \\
\hline \multicolumn{1}{c}{ Nuclide } & (Bq/yr) & $\%$ Total \\
\hline H-3 & $4.26 \times 10^{+12}$ & $99.1 \%$ \\
C-11 & $2.37 \times 10^{+10}$ & $0.6 \%$ \\
F-18 & $1.30 \times 10^{+10}$ & $0.3 \%$ \\
N-13 & $3.11 \times 10^{+9}$ & $<0.1 \%$ \\
O-15 & $2.22 \times 10^{+8}$ & $<0.1 \%$ \\
C-14 & $4.08 \times 10^{+7}$ & $<0.1 \%$ \\
I-125 & $1.39 \times 10^{+7}$ & $<0.1 \%$ \\
All others & $4.88 \times 10^{+5}$ & $<0.1 \%$ \\
\hline Total & $4.30 \times 10^{+12}$ & $100.0 \%$ \\
\hline
\end{tabular}

*For a complete list of radiological air emissions, see NESHAPs Annual Report for 1998, found on Berkeley Lab's EH\&S Web site at http://www.lbl. gov/ehs/html/env_protection.htm. 


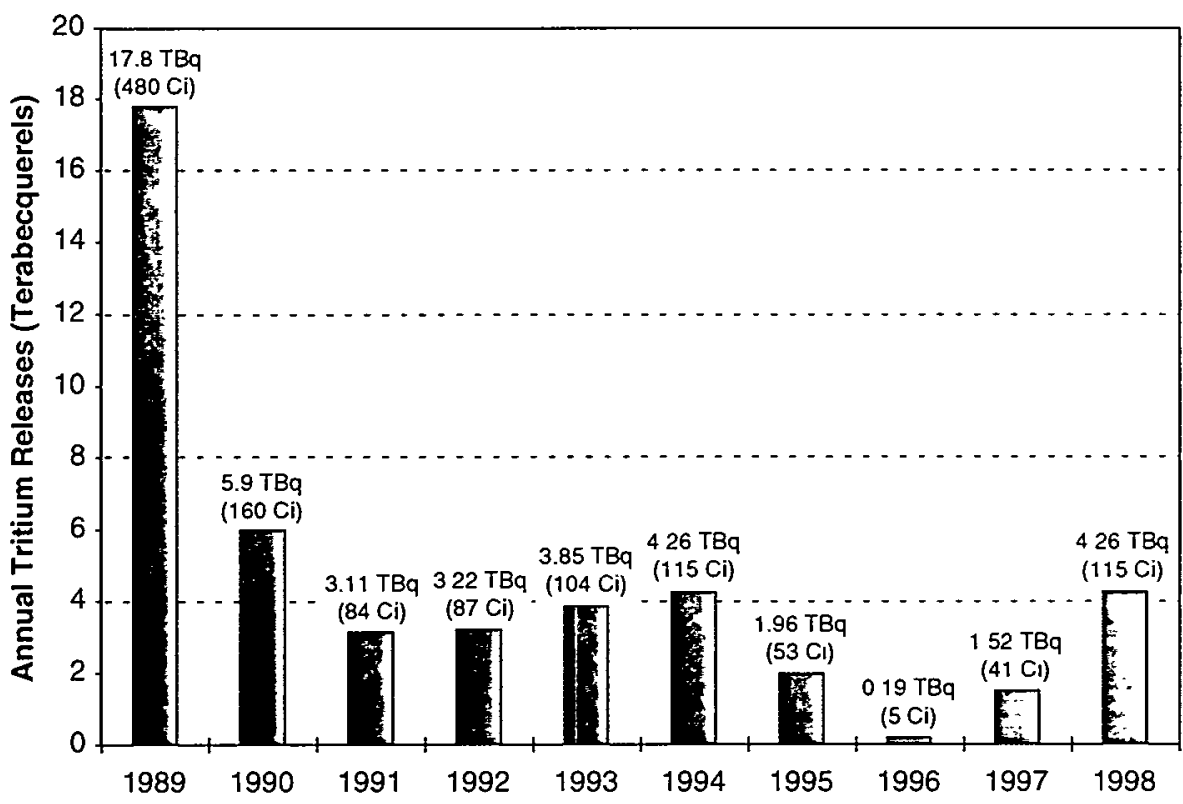

Figure 4-1 Trends in Annual Tritium Releases from NTLF

\section{AMBIENT AIR MONITORING RESULTS}

\section{$\$ 4.3$ A. Tritium}

Berkeley Lab operated six monitoring sites in 1998 to determine levels of airborne tritium in the environment. Three of the locations were on site and three were off site, as seen in Figure 4-2. The sites were chosen based on known emission sources, local wind patterns, and proximity to off-site residential areas and facilities. Monitoring equipment at all sites continuously samples outdoor air at a constant rate. The sampling media are replaced and analyzed monthly.

Table 4-5 summarizes the network's atmospheric tritium concentrations for the year. Average and maximum concentration values are far below $1 \%$ of the allowable Department of Energy annual exposure standard for tritium in air. ${ }^{6}$ The 1998 ambient air results for the network are similar to the results from the previous year and well below levels measured as recently as 1995 . For example, the annual average concentration at the highest reporting station, ENV-69, dropped from $24 \mathrm{~Bq} / \mathrm{m}^{3}\left(650 \mathrm{pCi} / \mathrm{m}^{3}\right)$ in 1995 to $1.72 \mathrm{~Bq} / \mathrm{m}^{3}\left(46 \mathrm{pCi} / \mathrm{m}^{3}\right)$ in 1998 . Improved field sampling and analytical laboratory techniques are key reasons for this improvement. The 1998 results are also consistent with dispersion modeling results of stack emissions required by NESHAPs. See $\$ 10.5$. 


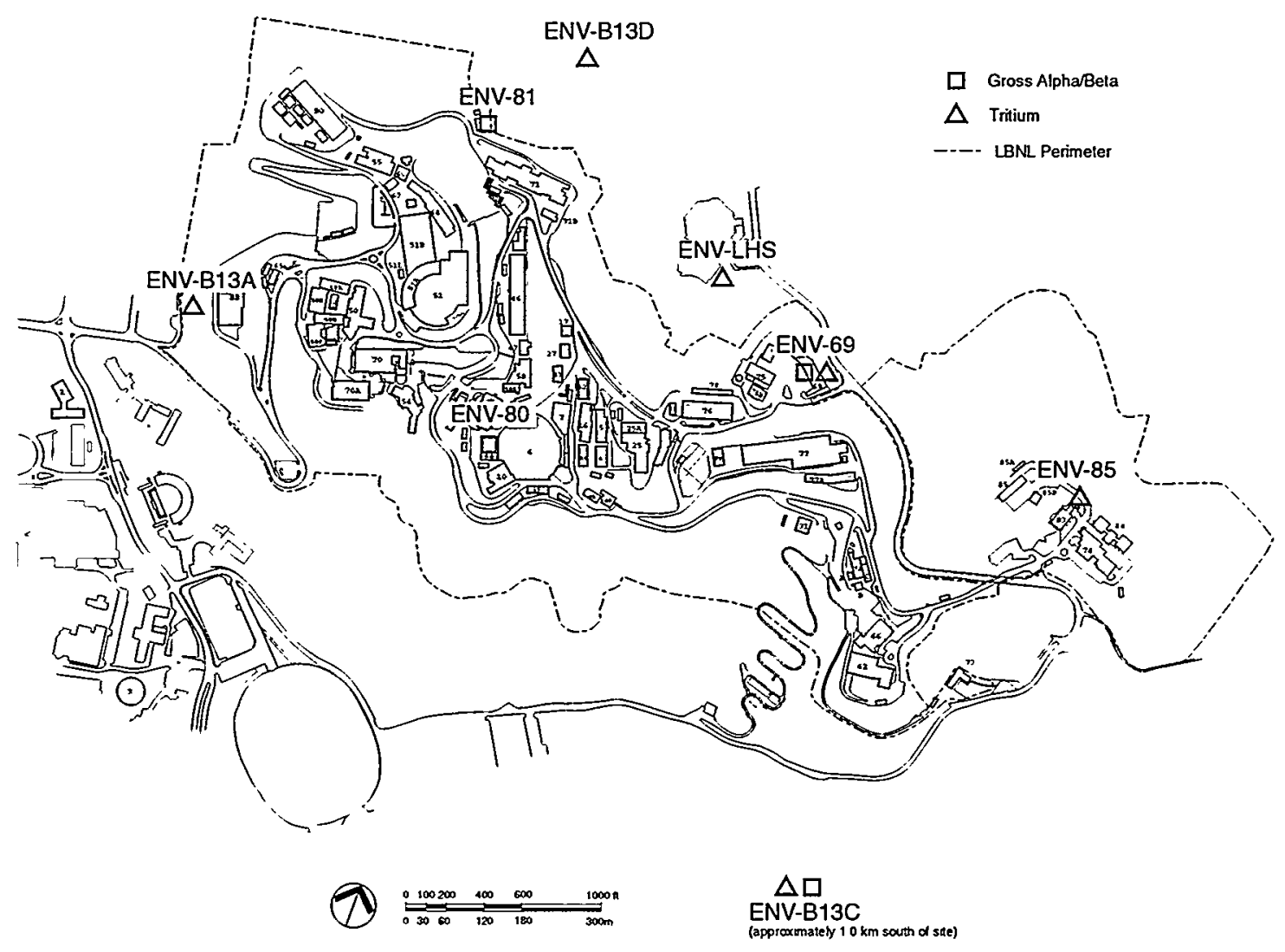

Figure 4-2 Ambient Air Monitoring Network Sampling Locations

Table 4-5 Summary of Ambient Tritium Sampling

\begin{tabular}{lccccc}
\hline Station ID & $\begin{array}{c}\text { Number of } \\
\text { samples }\end{array}$ & $\begin{array}{c}\text { Mean } \\
\left(\mathrm{Bq} / \mathrm{m}^{3}\right)\end{array}$ & $\begin{array}{c}\text { Mean as percent } \\
\text { of standard }\end{array}$ & $\begin{array}{c}\text { Median } \\
\left(\mathrm{Bq} / \mathrm{m}^{3}\right)\end{array}$ & $\begin{array}{c}\text { Maximum } \\
\left(\mathrm{Bq} / \mathrm{m}^{3}\right)\end{array}$ \\
\hline ENV-B13A & 12 & $<0.11^{\mathrm{b}}$ & - & $<0.11^{\mathrm{b}}$ & 0.15 \\
ENV-B13C & 12 & $<0.11^{\mathrm{b}}$ & - & $<0.11^{\mathrm{b}}$ & $<0.11^{\mathrm{c}}$ \\
ENV-B13D & 12 & 0.12 & 0.003 & $<0.11^{\mathrm{b}}$ & 0.29 \\
ENV-69 & 12 & 1.72 & 0.05 & 0.94 & 8.91 \\
ENV-85 & 12 & 0.26 & 0.007 & 0.12 & 1.52 \\
ENV-LHS & 12 & 1.72 & 0.05 & 1.71 & 3.96 \\
\hline
\end{tabular}

a Standard of comparison $=3.7 \times 10^{3} \mathrm{~Bq} / \mathrm{m}^{3}$ (source: DOE Order 5400.5)

${ }^{b}$ Statistic was below the maximum MDA for this site.

c All results for this site were "nondetect." 


\section{$\$ 4.4 \quad$ B. Gross Alpha/Beta}

The ambient air sampling network also included a series of stations designed to measure gross alpha and gross beta levels in particulate emissions. This network complements the exhaust system sampling for the same parameters, discussed earlier in this chapter. The network consists of four monitoring sites: three sites on the main grounds of the Laboratory and a fourth site at the monitoring program's most remote station, ENVB13C. As with tritium sampling, the samplers draw air past collection media at a constant rate, with the media replaced monthly and samples analyzed by certified laboratories.

Table 4-6 summarizes gross alpha and beta results from sampling activities in 1998. Although DOE Order 5400.5 does not provide a standard for particulate gross alpha and beta radiation, ${ }^{9}$ several observations about these results are apparent:

- They are extremely low, approaching or remaining below the analytical detection limits for each parameter;

- There is little variability from station to station, including station ENV-B13C located over 1.0 kilometer ( 0.6 mile) south of the site; and

- The results for each parameter change very little from one year to the next.

These observations indicate that environmental impacts from the Laboratory's radioactive releases of alpha and beta emitting isotopes to the atmosphere are negligible.

Table 4-6 Gross Alpha and Beta Sampling Results from Ambient Air Monitoring Network

\begin{tabular}{llcccc}
\hline Analyte & Station ID & $\begin{array}{c}\text { Number of } \\
\text { samples }\end{array}$ & $\begin{array}{c}\text { Mean } \\
\left(\mathrm{Bq} / \mathrm{m}^{3}\right)\end{array}$ & $\begin{array}{c}\text { Median } \\
\left(\mathrm{Bq} / \mathrm{m}^{3}\right)\end{array}$ & $\begin{array}{c}\text { Maximum } \\
\left(\mathrm{Bq} / \mathrm{m}^{3}\right)\end{array}$ \\
\hline Alpha & ENV-B13C & 12 & $<1.1 \times 10^{-4}$ & $<1.1 \times 10^{-4}$ & $1.3 \times 10^{-4}$ \\
& ENV-69, b & 12 & $<1.1 \times 10^{-4}$ & $<1.1 \times 10^{-4}$ & $<1.1 \times 10^{-4}$ \\
& ENV-80 & 12 & $<1.1 \times 10^{-4}$ & $<1.1 \times 10^{-4}$ & $1.4 \times 10^{-4}$ \\
& ENV-81 & 12 & $<1.1 \times 10^{-4}$ & $<1.1 \times 10^{-4}$ & $1.4 \times 10^{-4}$ \\
\hline Beta & ENV-B13C & 12 & $4.8 \times 10^{-4}$ & $4.1 \times 10^{-4}$ & $7.5 \times 10^{-4}$ \\
& ENV-69 & 12 & $4.5 \times 10^{-4}$ & $4.3 \times 10^{-4}$ & $6.7 \times 10^{-4}$ \\
& ENV-80 & 12 & $4.5 \times 10^{-4}$ & $4.3 \times 10^{-4}$ & $6.8 \times 10^{-4}$ \\
& ENV-81 & 12 & $4.6 \times 10^{-4}$ & $4.1 \times 10^{-4}$ & $8.7 \times 10^{-4}$ \\
\hline
\end{tabular}

a Both the mean and median were below the maximum MDA for this site.

b All results for this site were "nondetect." 


\section{5 \\ Surface Water}

I. BACKGROUND $\$ 5.1$

II. SURFACE WATER RESULTS

A. Rainwater $\$ 5.2$

Figure 5-1: Rainwater and Lake Sampling Locations

Figure 5-2: Rainwater Radiological Monitoring Results

B. Creeks $\$ 5.3$

Figure 5-3: Creek Sampling Locations

Figure 5-4: Creek Tritium Monitoring Results

Figure 5-5: Annual Averages for Tritium in Chicken Creek (1994-1998)

C. Lakes $\$ 5.4$

D. Hydraugers $\$ 5.5$

Figure 5-6: Hydrauger Sampling Locations

Figure 5-7: Hydrauger Tritium Monitoring Results

E. Stormwater $\$ 5.6$

Figure 5-8: Stormwater and Creekwater Baseline Sampling Locations

\section{$\$ 5.1 \quad$ I. BACKGROUND}

Berkeley Lab's surface water monitoring includes rainwater, creeks, lakes, hydraugers, and stormwater. The first four surface water types are monitored primarily for gross alpha, gross beta, and tritium, based on Department of Energy orders ${ }^{1}$ that prescribe monitoring for radioisotopes. Nonradiological sampling of surface water occurs as part of the Laboratory's ongoing efforts to characterize and manage its overall impact on the environment. Stormwater monitoring is performed under the California General Permit for Stormwater Discharges Associated with Industrial Activities ${ }^{2}$ and includes monitoring for metals and other constituents. The monitoring programs for each type of surface water are further described in this chapter.

To place the Laboratory's results into a familiar context, this chapter cites drinking water standards as a comparison for results from certain sampling programs. In actuality. 
the drinking water standard is not a compliance standard for the surface water program (no such standard exists), and the water being monitored is not a source of public drinking water.

Surface water samples were analyzed in 1998 by both commercial and in-house state-certified laboratories. Individual results can be found in volume II.

\section{SURFACE WATER RESULTS}

\section{$\$ 5.2$ A. Rainwater}

Monthly rainwater composite samples are collected when rainfall occurs. In 1998, June, July, August, and September were dry months, so no samples were collected for those months.

Samples collected throughout the year came from three locations. See Figure 5-1. One location (ENV-75) is on site, near Building 75. Of the two off-site locations, one (ENV-B13C) is south of Berkeley Lab on Panoramic Hill, and one (ENV-B13D) is located northwest of the Lawrence Hall of Science.

Samples were analyzed for tritium and gross alpha and beta radiation. Figure 5-2 summarizes the levels of alpha, beta, and tritium seen in rainwater samples taken during 1998. Alpha and beta activity were either not detected or seen in low amounts at all
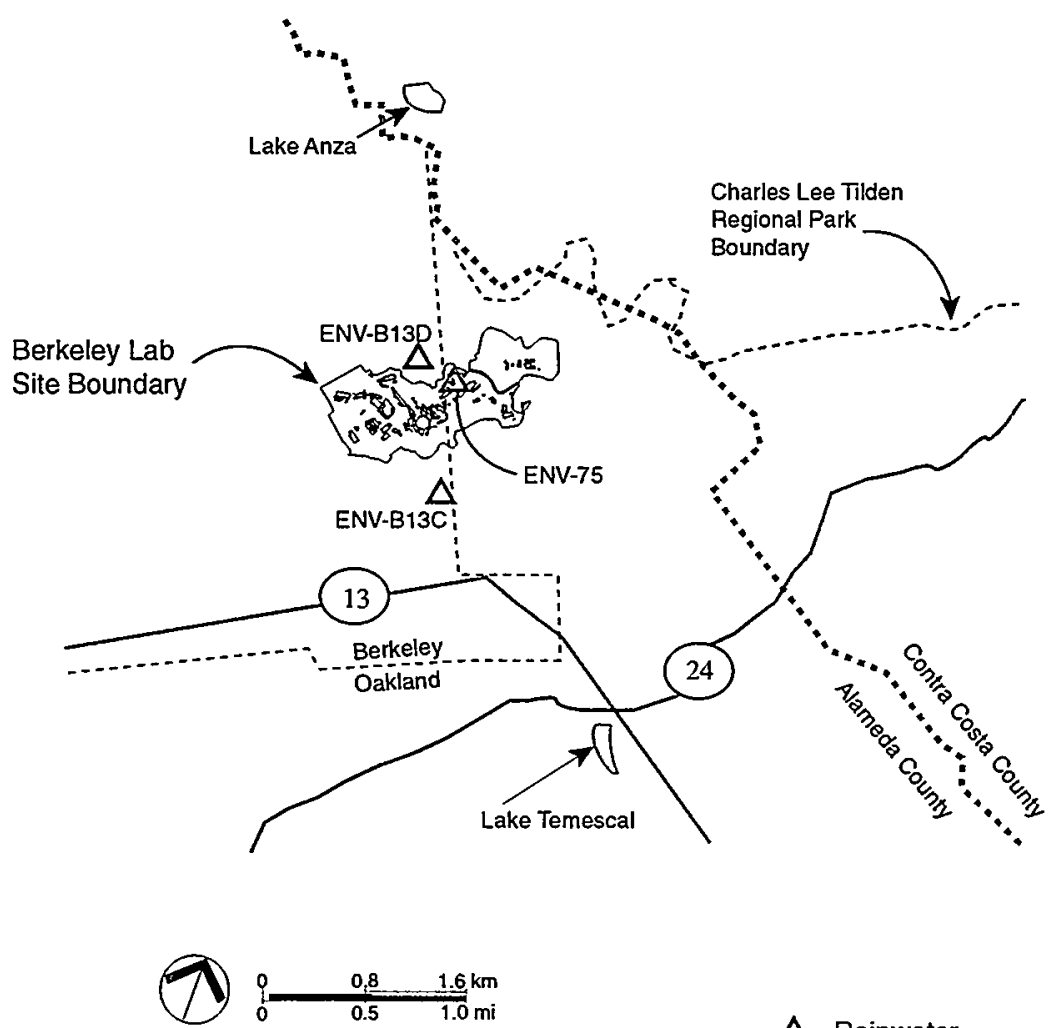

$\triangle$ Rainwater

Figure 5-1 Rainwater and Lake Sampling Locations 


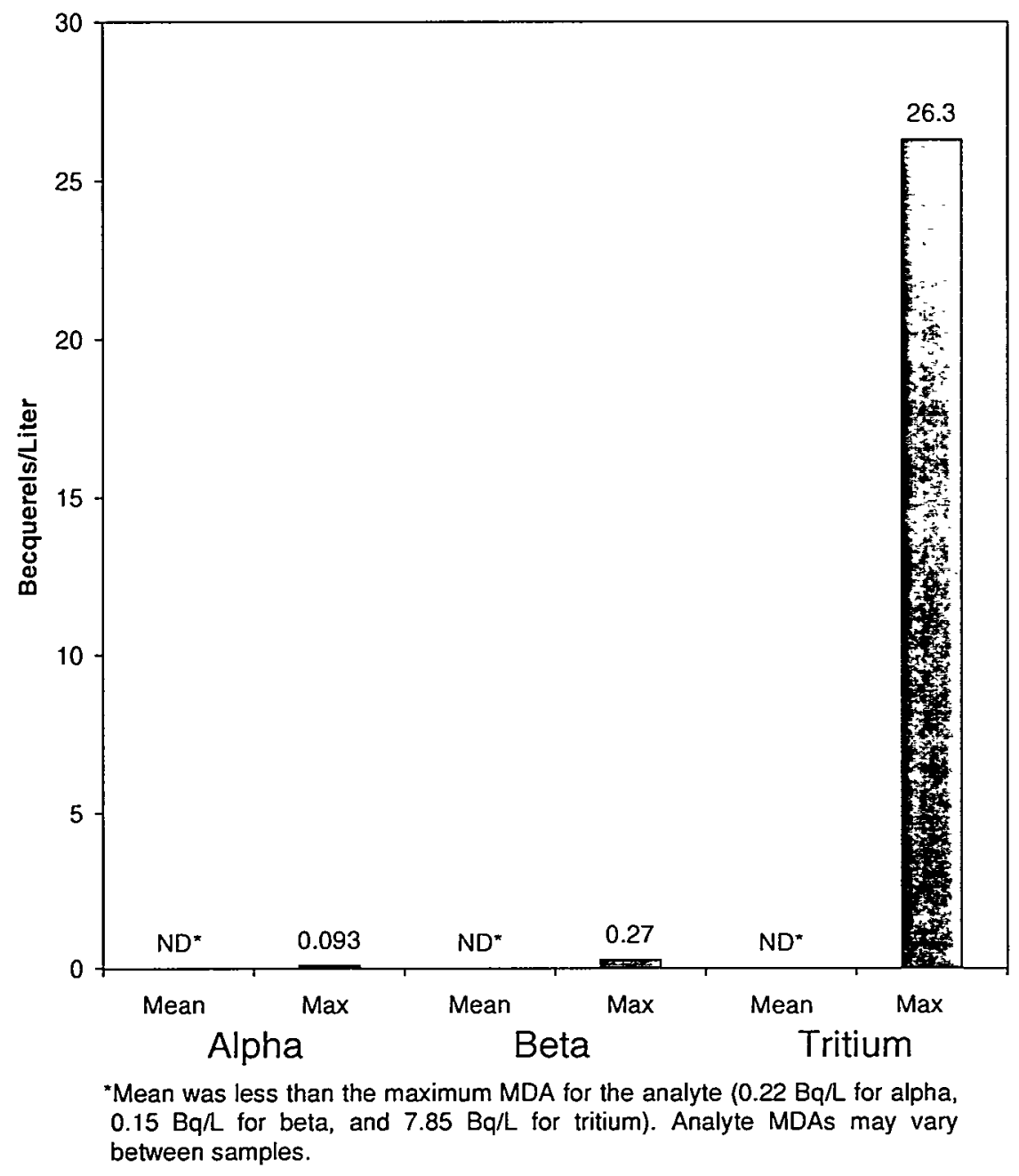

Figure 5-2 Rainwater Radiological Monitoring Results

stations, below federal and state maximum contaminant levels (MCLs) for drinking water: $0.6 \mathrm{~Bq} / \mathrm{L}(15 \mathrm{pCi} / \mathrm{L})$ for alpha and $1.9 \mathrm{~Bq} / \mathrm{L}(50 \mathrm{pCi} / \mathrm{L})$ for beta. ${ }^{3}$

Tritium was generally not detected in rainwater collected at off-site locations. On site, the maximum tritium level in rainwater was measured in the sample collected at ENV-75 in March $(26.3 \mathrm{~Bq} / \mathrm{L})$. The mean tritium level for rainwater samples collected at ENV-75 was $11.8 \mathrm{~Bq} / \mathrm{L}$. For comparison, the maximum tritium level in rainwater represents approximately $3.5 \%$ of the US/EPA drinking water limit $(740 \mathrm{~Bq} / \mathrm{L}$ or 20,000 $\mathrm{pCi} / \mathrm{L}){ }^{4}$

\section{$\S 5.3$ B. Creeks}

Given Berkeley Lab's location in the hills of the Strawberry Creek watershed, many streams and creeks at and near the site flow at varying intensities throughout the course of the year. When creek flow occurs, a grab sample is collected and analyzed quarterly for alpha and beta activity and tritium. Creeks routinely sampled during 1998 were Chicken 
Creek, Claremont Creek, the North Fork of Strawberry Creek, Strawberry Creek (UC), and Wildcat Creek. See Figure 5-3 for locations.

A second set of creeks was also sampled and analyzed for tritium only. These creeks (also shown in Figure 5-3) include Botanical Garden Creek, Cafeteria Creek, No Name Creek, Ravine Creek, and Ten-Inch Creek.

No alpha or beta activity was detected at any sampling site, with the exception of very low amounts of both at Claremont Creek during the May sampling. Tritium was also generally not detected, except in Chicken Creek, where it was always seen at low levels. Measurable, though small, amounts of tritium were also found three times in the North Fork of Strawberry Creek and once in Wildcat Creek. A summary of tritium results above detection limits for creek sampling in 1998 is shown in Figure 5-4.

Chicken Creek is the only creek in which tritium has been found with any regularity. Figure 5-5 presents a comparison of the annual mean for tritium over the last five years in Chicken Creek. From a high of $43.9 \mathrm{~Bq} / \mathrm{L}(1,190 \mathrm{pCi} / \mathrm{L})$ in 1995 , levels dropped by nearly half in 1996 to $23 \mathrm{~Bq} / \mathrm{L}(620 \mathrm{pCi} / \mathrm{L})$ and have remained reasonably consistent since then.

One sample was collected during the year from the second set of creek sites and analyzed for tritium and nonradiological parameters (volatile organic compounds (VOCs), hardness, and metals). The North Fork of Strawberry was also sampled a second time for VOCs, semivolatiles, tritium, and metals. All semivolatiles and VOCs were

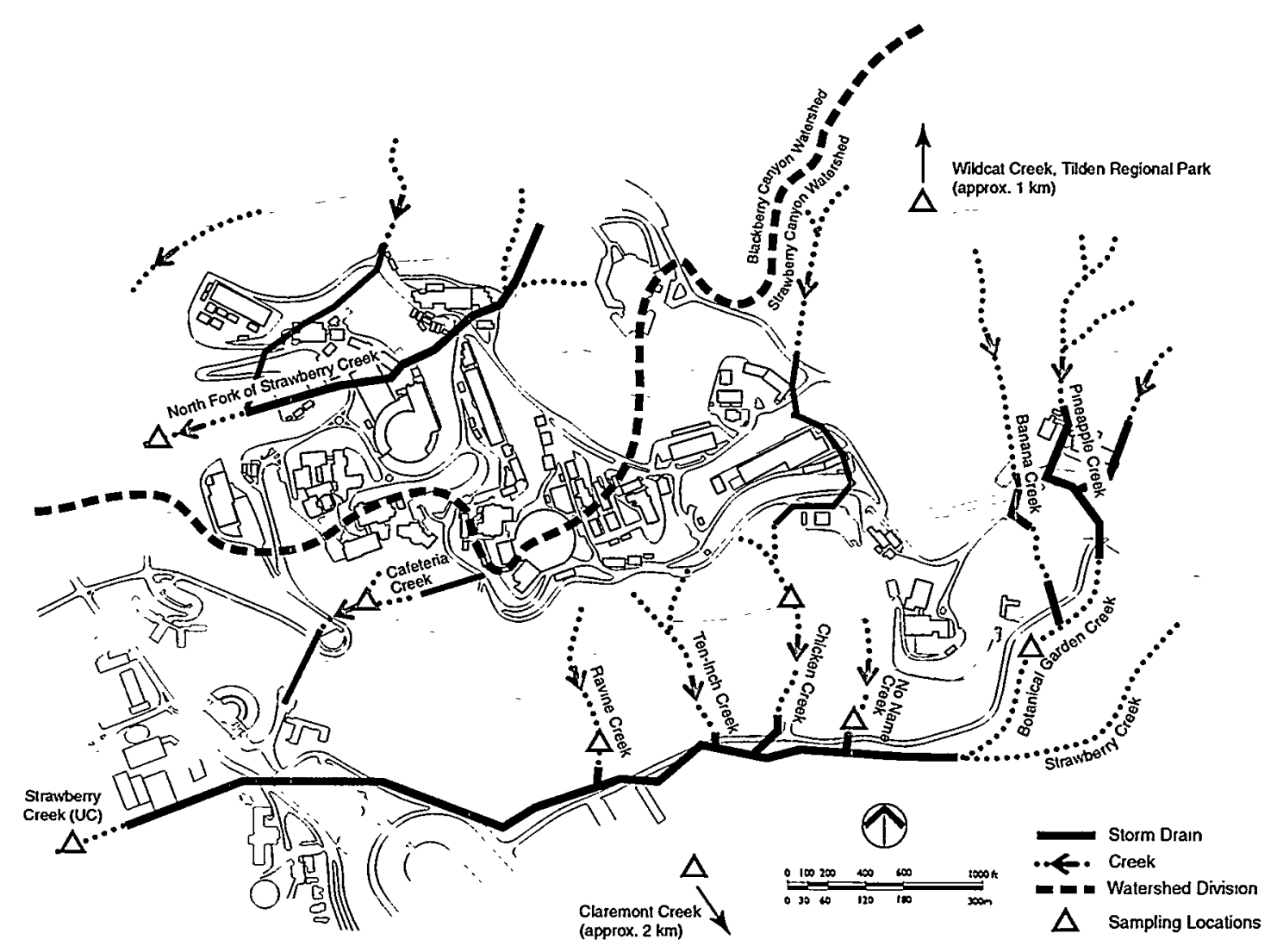

Figure 5-3 Creek Sampling Locations 


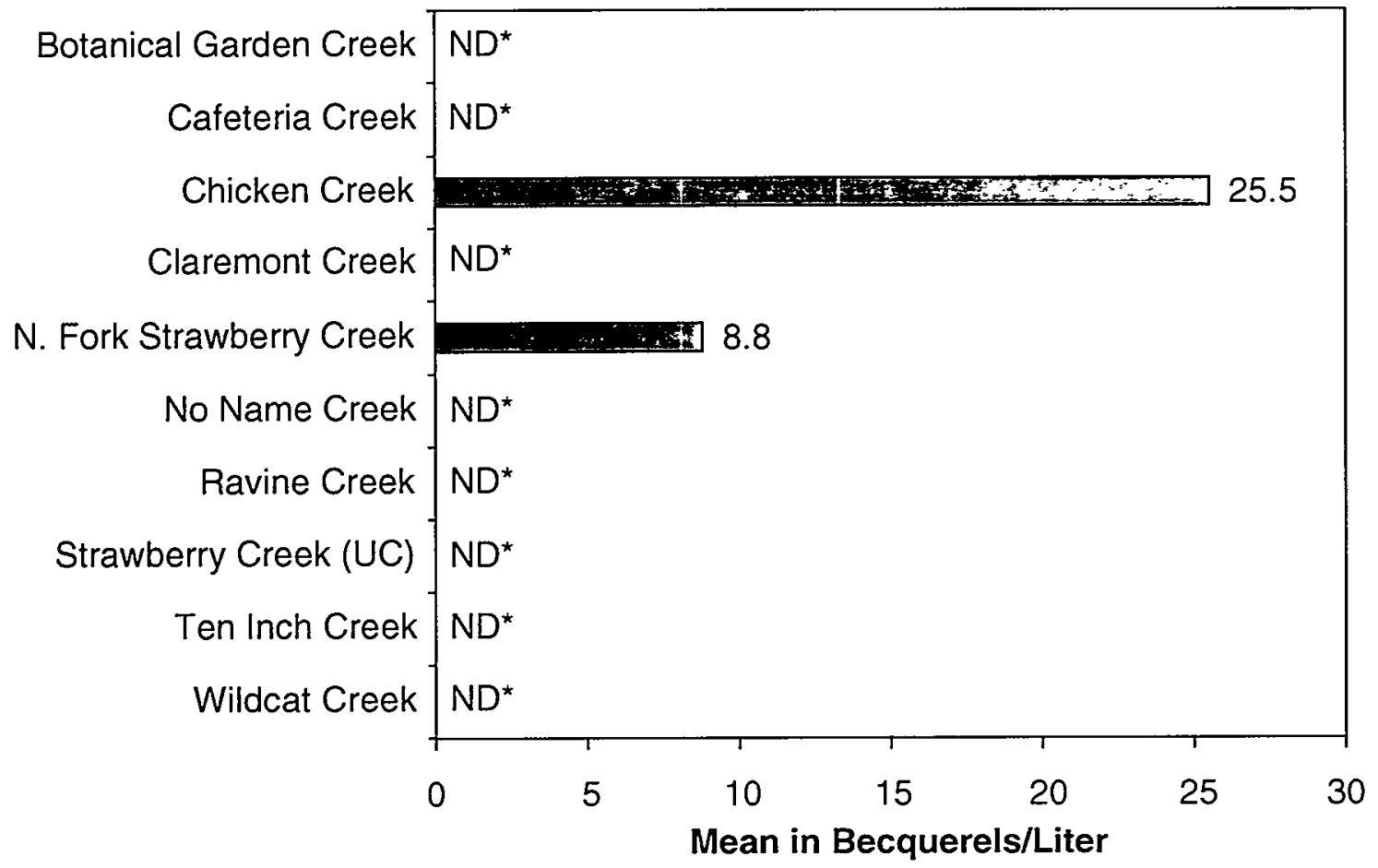

"Mean was less than the highest minimum detectable amount for the analyte at this site.

Figure 5-4 Creek Tritium Monitoring Results

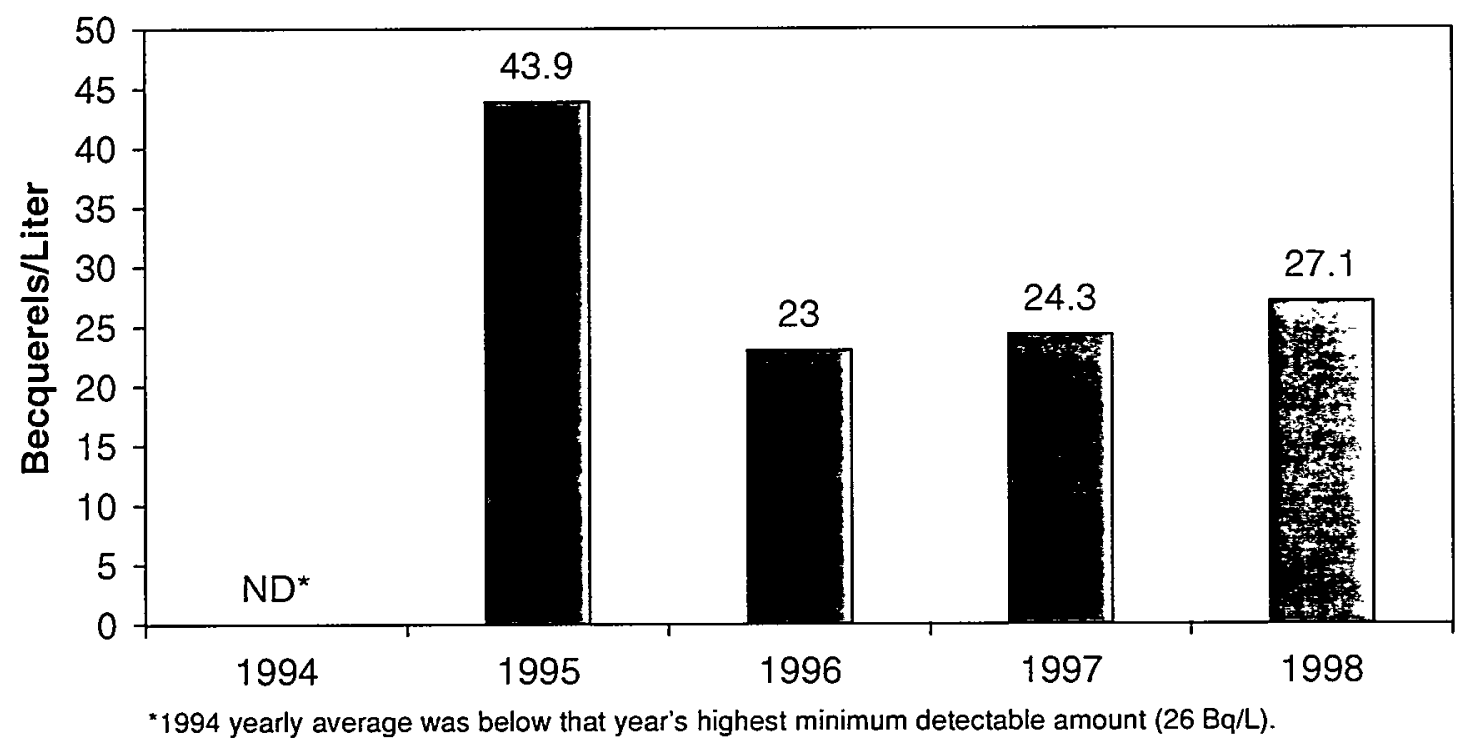

Figure 5-5 Annual Averages for Tritium in Chicken Creek (1994-1998) 
below detectable levels, except for one measurement for diethylphthalate in the North Fork of Strawberry Creek. A repeat sampling of semivolatiles also showed this to be below detectable levels. No tritium was detected in any of the creeks sampled in this set. Trace levels of barium, chromium, copper, lead, molybdenum, selenium, vanadium, and zinc were found. These levels were consistent with past results and with natural background levels.

\section{$\$ 5.4$ C. Lakes}

Lake sampling is performed once each year at Lake Anza in Tilden Regional Park and at Lake Temescal in Oakland's Temescal Regional Park. See Figure 5-1. For 1998, no samples from either lake contained alpha or beta activity or tritium above minimum detectable amounts.

\section{$\$ 5.5$ D. Hydraugers}

Because of its steep hillsides, Berkeley Lab uses hydraugers to manage soil stability. Hydraugers are perforated pipes inserted into a hillside to improve drainage of groundwater. Figure 5-6 shows the locations of monitored hydraugers. In 1998, the frequency of hydrauger monitoring was reduced from quarterly to semi-annually. Summary tritium data for hydraugers are displayed in Figure 5-7.

Five hydrauger sites (HYG77-0101, HYG77-0104, HYG77-02XX, HYGCC1, and HYGCC2) were routinely monitored in 1998 for alpha, beta, and tritium. HYG77-0103 has been deleted from the program because of lack of flow. HYG77-02XX is a manifold of several hydraugers (HYG77-0204 through HYG77-0207) and is sampled at the common discharge point. Hydraugers prefixed with HYG77 are located behind Building 77, while those prefixed with HYGCC are located near Chicken Creek, further to the south and further down the hillside.

Because hydrauger flow depends on several factors (including rainfall), it can vary considerably. No flow or very low flow prevents samples from being taken. For example, HYG77-0104 was dry in all four quarters during 1998, and no samples could be taken from it.

At the hydraugers that could be sampled, alpha and beta were always below detection limits. Tritium levels varied considerably. Tritium was detected in $73 \%$ and $33 \%$ of the samples collected from the HYG77 and HYGCC hydraugers, respectively. The highest level measured was $504 \mathrm{~Bq} / \mathrm{L}$ for a sample collected at HYG77-0101 on January 20. 


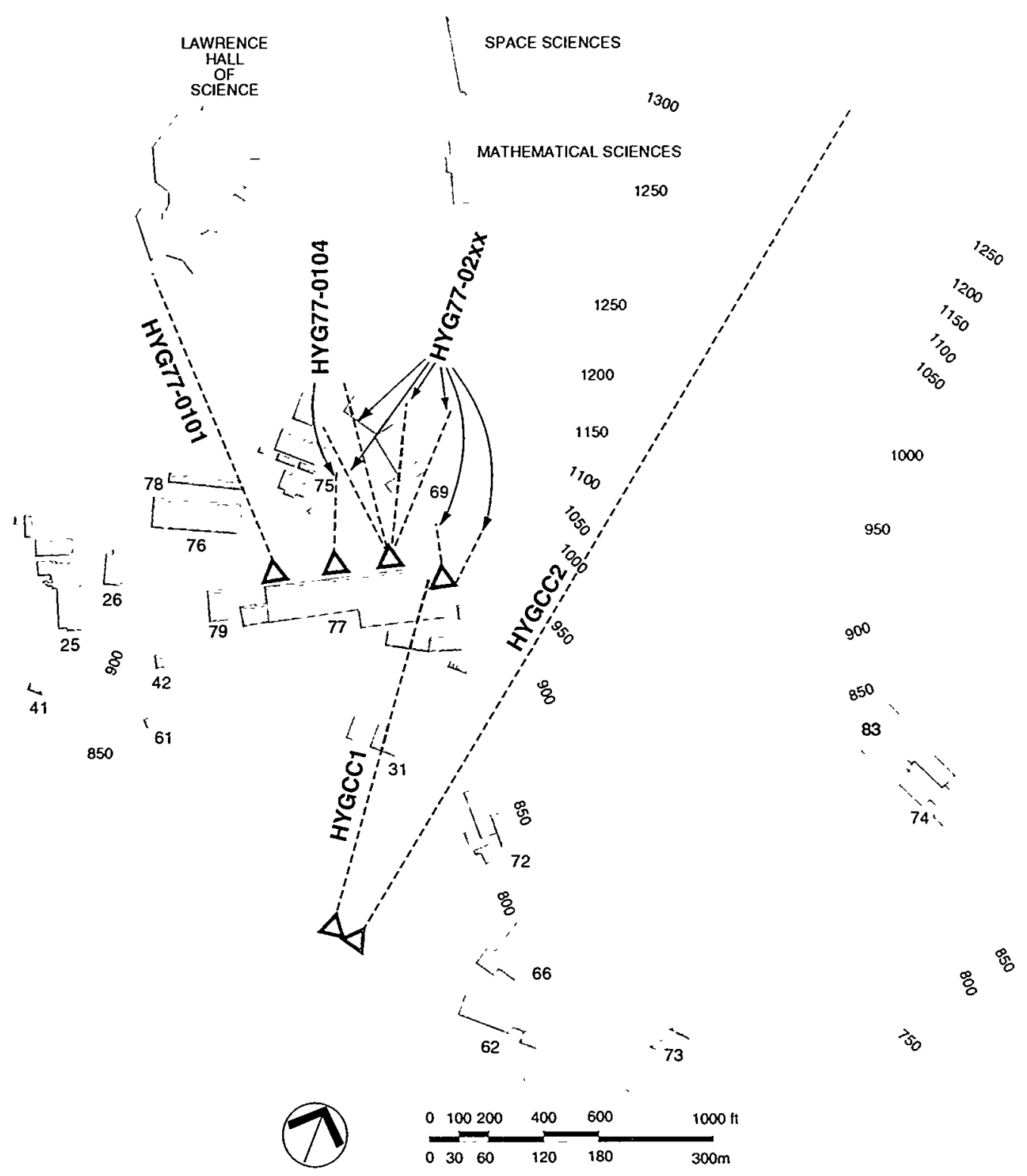

Figure 5-6 Hydrauger Sampling Locations 


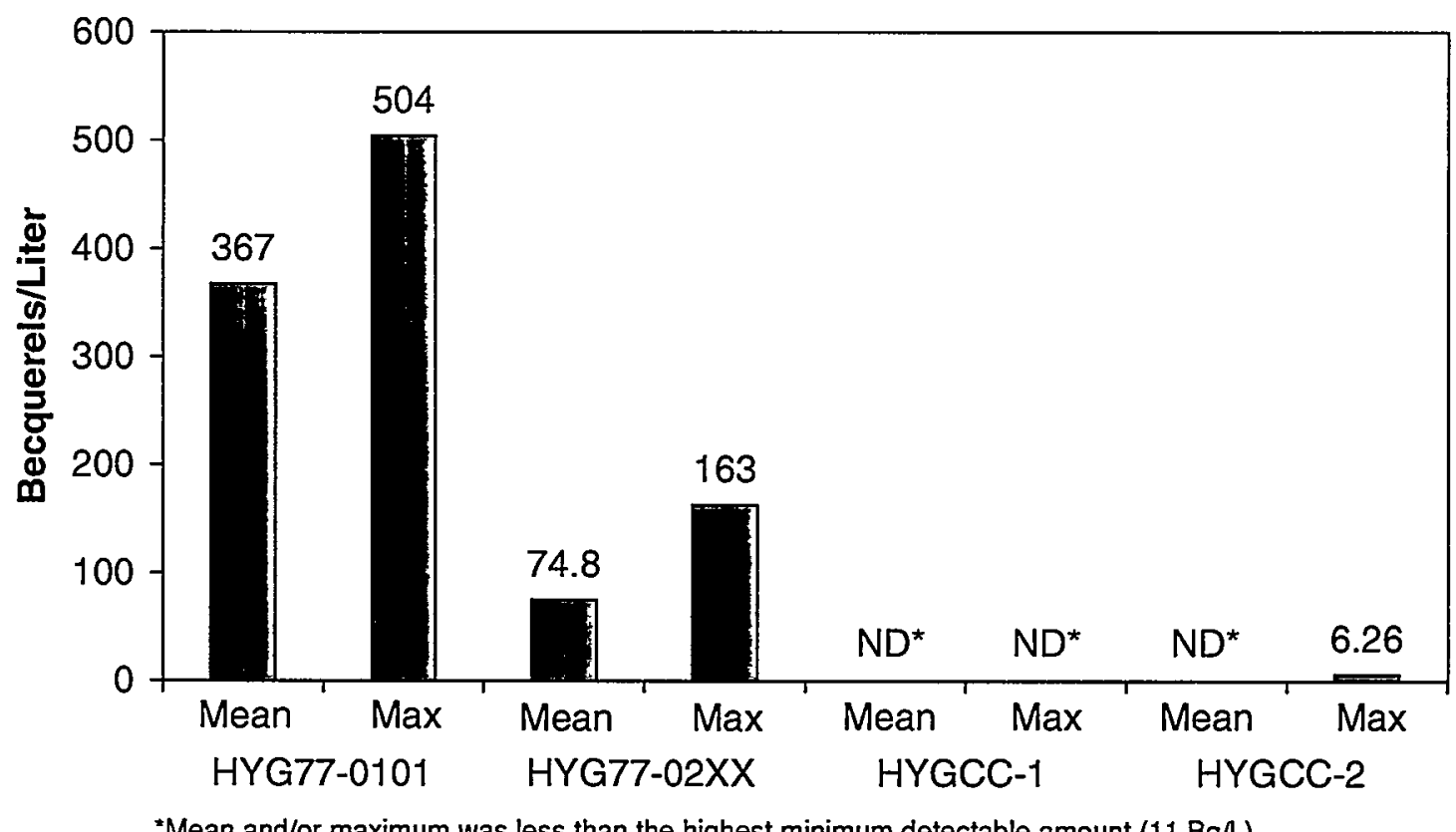

Figure 5-7 Hydrauger Tritium Monitoring Results

\section{$\$ 5.6 \quad$ E. Stormwater}

Berkeley Lab lies within the Blackberry Canyon and Strawberry Canyon watersheds. There are two main creeks in the watershed, Strawberry Creek and the North Fork of Strawberry Creek, plus several small tributaries that generally do not flow all year long. See Figure 5-8.

Surface runoff from Berkeley Lab is substantial because of the site's hillside location, the amount of paved or covered surface, and the moderate annual rainfall. All stormwater runoff from the site drains through this system to Strawberry Creek or its north fork, which join below the Laboratory on the UC Berkeley campus.

Under the State of California's National Pollutant Discharge Elimination System (NPDES) program, Berkeley Lab must follow the General Permit for Stormwater Discharges Associated with Industrial Activities. ${ }^{5}$ Permit holders must develop and maintain a Storm Water Monitoring Plan (SWMP) ${ }^{6}$ and a Storm Water Pollution Prevention Plan (SWPPP). ${ }^{7}$ These are the guiding documents for the Laboratory's compliance with stormwater regulations. For further discussion of this compliance program, see $\S \S 3.24$ and 3.26 .

Berkeley Lab's SWMP explains the rationale for sampling, sampling locations, and the kinds of radiological and nonradiological analyses to be performed. For metals, the permit requires analysis for total metals. Following a request from the City of Berkeley, however, Berkeley Lab has committed to analyzing at least one sample per stormwater year for both total and dissolved metals as a comparison. Dissolved metals are consistently lower than total metals. Sampling points are shown in Figure 5-8.

Two of the monitoring points, StW01 and StW03, are influent points, where stormwater comes onto the site from residential areas, roads, and UC Berkeley campus 


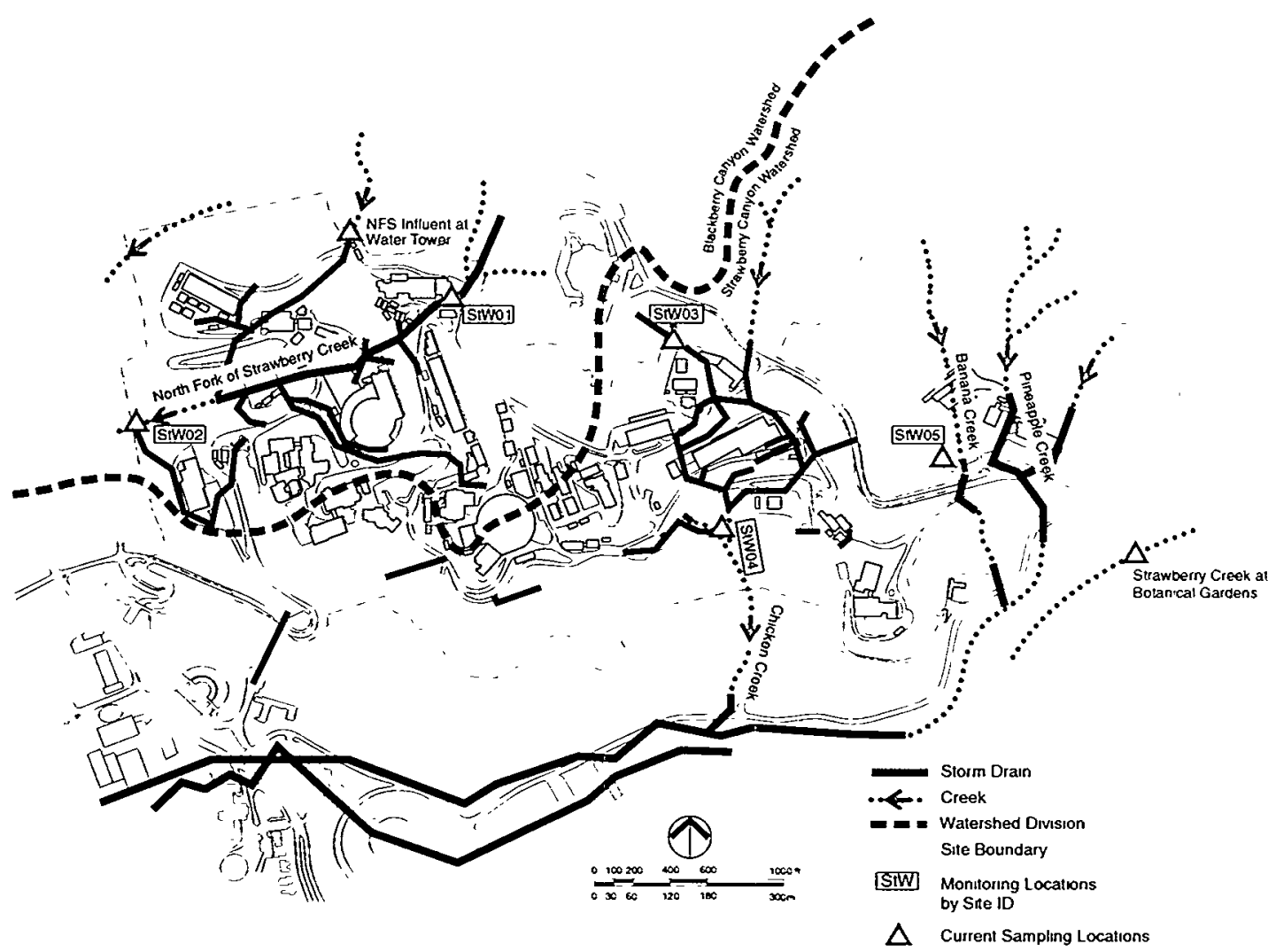

Figure 5-8 Stormwater and Creekwater Baseline Sampling Locations

facilities located above Berkeley Lab. These points were chosen as a basis of comparison and to aid in an investigation if contaminants are found.

Under the terms of the general permit, sampling must take place at least twice each "stormwater year" (July 1 through June 30) under specific conditions. Monitoring also includes visual observation of one storm per month and quarterly observation of authorized and unauthorized nonstormwater discharges. All sampling points must be monitored for the following:

- Total suspended solids, $\mathrm{pH}$, specific conductance, and total organic carbon (TOC). Oil and grease may be substituted for TOC.

- Toxic chemicals and other pollutants that are likely to be present in stormwater discharge in significant quantities.

Note that in calendar year 1998, stormwater monitoring was performed only once because of rainfall patterns during the 1998-1999 stormwater year.

In 1998, $\mathrm{pH}$ was always near neutral, and total petroleum hydrocarbons (diesel) and oil and grease (both tests for gas or oil) were once detected in very low quantities in Chicken Creek and B69 Storm Drain (StW03), its influent point. Interestingly, levels decreased between the influent and effluent points, indicating that the site may actually be retaining contaminants. Specific conductance, usually a measure of the degree of mineralization of water, was low and within the range of domestic drinking water. The measure for total suspended solids (TSS) was also usually quite low, indicating clear 
water. B69 Storm Drain was an exception; it had a relatively higher number for TSS in the influent point. Chemical oxygen demand, filtered (CODF), is a measure that can be correlated to the amount of organic matter in the water. CODF results in stormwater discharge for the Laboratory were generally low.

Metals results were generally in the "nondetect" range. Only aluminum, iron, and manganese were occasionally seen at low levels in the total metals analyses. The general permit does not contain specific discharge limits for metals. For comparison purposes, Table 4-3 of the Basin Plan ${ }^{8}$ gives effluent limitations for selected toxic pollutants discharged to shallow surface waters applicable to point source discharges from Publicly Owned Treatment Works (like the East Bay Municipal Utility District) and industrial effluent.

Routine stormwater samples are also analyzed for alpha and beta emitters and tritium. Neither alpha nor beta emitters were detected. All tritium values were low, ranging from $8.7 \mathrm{~Bq} / \mathrm{L}(235 \mathrm{pCi} / \mathrm{L})$ at East Canyon (StW05) to $65.2 \mathrm{~Bq} / \mathrm{L}(1,760 \mathrm{pCi} / \mathrm{L})$ at Building 69 Influent (StW03). The influent point at Building 69 consistently has the highest values for tritium in stormwater. The tritium value for the corresponding effluent point, Chicken Creek or StW04, is about half that level at $35.1 \mathrm{~Bq} / \mathrm{L}(948 \mathrm{pCi} / \mathrm{L})$.

During 1998, Berkeley Lab completed the special creek water baseline project, which was initiated in 1997 and described in last year's Site Environmental Report. The goal of this internal project was to establish a baseline for the quality of creek water being discharged from the site. The last phase of the project occurred in 1998, concomitant with the second stormwater sampling for the 1997-1998 season.

As with the first and second sampling rounds, samples were taken from the North Fork of Strawberry Creek, Strawberry Creek at the Botanical Garden, Chicken Creek, and B71 Storm Drain, an influent point. In addition, B69 Storm Drain, the Water Tower on the North Fork of Strawberry (both influent points), and East Canyon were also sampled. See Figure 8. Analyses were run for the following:

- Metals;

- Total petroleum hydrocarbons as diesel, oil, and grease;

- General minerals;

- Nitrate/nitrite;

- Total suspended solids;

- Chemical oxygen demand;

- Gross alpha and beta; and

- Tritium.

Results in general are the same as the stormwater results described above. For the two additional monitoring locations, NFS influent at Water Tower and Strawberry Creek at Botanical Garden, no oil and grease, TPH diesel, or gross alpha or tritium were detected. At the Water Tower, beta activity was only slightly above the detection limit. CODF and TSS were within normal ranges, as were $\mathrm{pH}$ and specific conductance. Aluminum, barium, copper, iron, magnesium, manganese, and zinc were generally detected at low levels. Traces of nitrate and ammonia as nitrogen were detected in both locations. A normal range of constituents and levels was found in the general minerals analysis. 


\section{6}

\section{Groundwater}

\section{BACKGROUND $\$ 6.1$}

II. HYDROGEOLOGIC CHARACTERIZATION \$6.2
A. Hydrogeologic Units
$\$ 6.3$
B. Groundwater Flow $\$ 6.4$

Figure 6-1: Groundwater Piezometric Map

C. Groundwater Fluctuations $\$ \mathbf{\$ 6 . 5}$

Figure 6-2: Groundwater Fluctuation in Monitoring Well MW53-93-16-69 Versus Rainfall

D. Groundwater Quality $\$ 6.6$

Table 6-1: Long-Term Average Mineral Concentrations in Different Formations

III. GROUNDWATER MONITORING RESULTS $\$ \mathbf{\$ 6 . 7}$

Figure 6-3: Approximate Locations of Monitoring Wells Closest to Berkeley Lab Property Line

Table 6-2: Metals Detected in Groundwater Samples from Monitoring Wells

Table 6-3: VOCs Detected in Groundwater Samples from Monitoring Wells

Table 6-4: Tritium Detected in Groundwater Samples from Monitoring Wells

IV. GROUNDWATER CONTAMINATION PLUMES $\$ 6.8$

Figure 6-4: Groundwater Contamination Plumes (December 1998)

\section{A. VOC Plumes $\$ 6.9$}

Figure 6-5: Groundwater Contamination (Total Halogenated Hydrocarbons in $\mu \mathrm{g} / \mathrm{L}$ ) in Old Town Area (December 1998)

Figure 6-6: Groundwater Contamination (Total Halogenated Hydrocarbons in $\mu \mathrm{g} / \mathrm{L}$ ) at Building 51/64 VOC Plume (December 1998)

B. Freon Plume $\$ 6.10$

C. Tritium Plume $\$ 6.11$ 


\section{Petroleum Hydrocarbon Plumes $\$ \mathbf{\$ 6 . 1 2}$}

Figure 6-7: Approximate Locations of Monitoring Wells Associated with Underground Storage Tanks

Table 6-5: Total Petroleum Hydrocarbon Concentrations at UST Sites

\section{INTERIM CORRECTIVE MEASURES \$6.13}
A. Source Removal or Control $\$ \mathbf{\$ 6 . 1 4}$
B. Preventing Discharge of Contamination to Surface Waters $\$ \mathbf{\$ 6 . 1 5}$
C. Preventing Further Migration of Contaminated Groundwater \$6.16
D. Treatment Systems $\$ \mathbf{\$ 6 . 1 7}$
Table 6-6: Treatment of Contaminated Groundwater

\section{$\$ 6.1$ I. BACKGROUND}

This section reviews the groundwater monitoring program at Berkeley Lab, emphasizing the 1998 results. Additional details on the program can be obtained in the Environmental Restoration Program (ERP) quarterly progress reports, which contain all the groundwater monitoring data, site maps showing monitoring well locations and contaminant concentrations, and graphs showing changes in contaminant concentrations over time. The quarterly progress reports are available for public review at the UC Berkeley campus Doe Library.

The Berkeley Lab groundwater monitoring program was started in 1991 to:

- Characterize the magnitude and extent of groundwater contamination;

- Evaluate the potential for future contaminant migration;

- Monitor groundwater quality near the site perimeter; and

- Monitor groundwater quality near existing and removed hazardous materials or hazardous waste storage units, including underground storage tanks.

The Groundwater Protection Management Program Plan ${ }^{1}$ established the program to accomplish these objectives by providing a framework for preventing future groundwater contamination and for remediating existing contamination at the site. The Laboratory has installed an extensive system of wells to monitor groundwater quality. Four categories of contaminants are monitored under the program: volatile organic compounds (VOCs), hydrocarbons, metals, and tritium. Selected wells are also sampled for other potential contaminants.

Under the RCRA Corrective Action Program, ${ }^{2}$ the Laboratory identifies areas of soil and groundwater contamination that may have resulted from past releases of contaminants to the environment. It then determines the sources and extent of the contamination and develops and implements remediation plans.

Activities are closely coordinated with the regulatory oversight agencies, including the Cal/EPA Department of Toxic Substances Control, San Francisco Bay Regional Water Quality Control Board, City of Berkeley, and the Department of Energy. These 
agencies review and comment on the work plans prepared for all activities. Berkeley Lab submits quarterly progress reports to these agencies and meets with them each quarter to review results of the previous quarter's activities.

Results in this chapter are compared against drinking water standards. Such a comparison should be interpreted with caution because the groundwater at the Berkeley Lab site is not used for human consumption.

\section{$\$$ II. HYDROGEOLOGIC CHARACTERIZATION}

Sections 6.3-6.6 discuss the hydrogeological setting of Berkeley Lab, including a review of the hydrogeologic units, a discussion of groundwater flow, and a description of the hydrologic properties of the shallow water-bearing zones. For more detailed information on hydrogeology, see the 1994 Berkeley Lab RCRA Facility Investigation Progress Report. ${ }^{3}$

\section{$\S 6.3 \quad$ A. Hydrogeologic Units}

Moraga Formation volcanic rocks, Orinda Formation sediments, and Great Valley Group sediments constitute the major rock units at the site. The structural geology and the physical characteristics of these three units are the principal hydrogeologic factors controlling the movement of groundwater and groundwater contaminants at the Laboratory. Two additional units, the Claremont Formation and the San Pablo Group, have a limited presence in the easternmost area of the Laboratory.

\section{$\$ 6.4$ B. Groundwater Flow}

Depth to water is measured monthly in all site monitoring wells. The depth to groundwater ranges from approximately 0 to 30 meters ( 0 to $98 \mathrm{feet}$ ). A groundwater piezometric map indicating the hydraulic head distribution at Berkeley Lab, based on water levels measured in wells, is given in Figure 6-1. This map indicates that the direction of groundwater flow generally follows the topography.

In the western part of Berkeley Lab, groundwater generally flows toward the west; in the rest of the Laboratory, groundwater generally flows toward the south. In some areas, groundwater flow directions show local deviations from the general trends shown on the piezometric map because of the subsurface geometry of geologic units and the contrasting hydrogeologic properties across geologic contacts. The velocity of the groundwater varies from approximately 0.001 meters per year $(0.003$ feet per year) to about 10 meters per day ( 33 feet per day).

\section{$\S 6.5 \quad$ C. Groundwater Fluctuations}

Fluctuations in measured groundwater levels in wells generally show a good correlation with rainfall, as shown in Figure 6-2. Generally, there is a fairly rapid response (on the order of days) of water levels in most site wells after rainfall occurs. Fluctuations as great as 4.2 meters (14 feet) are common in wells in the Old Town area. 


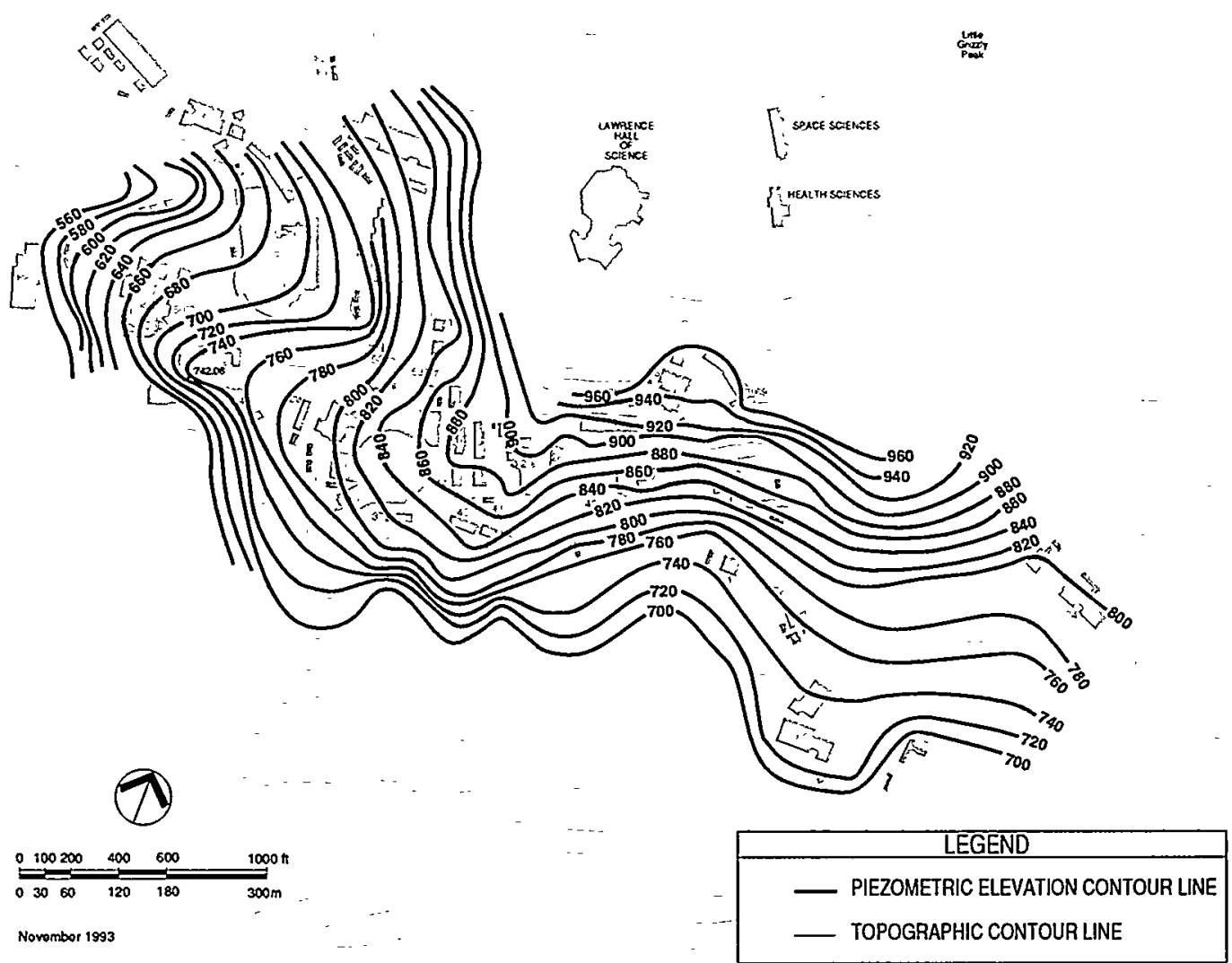

Figure 6-1 Groundwater Piezometric Map

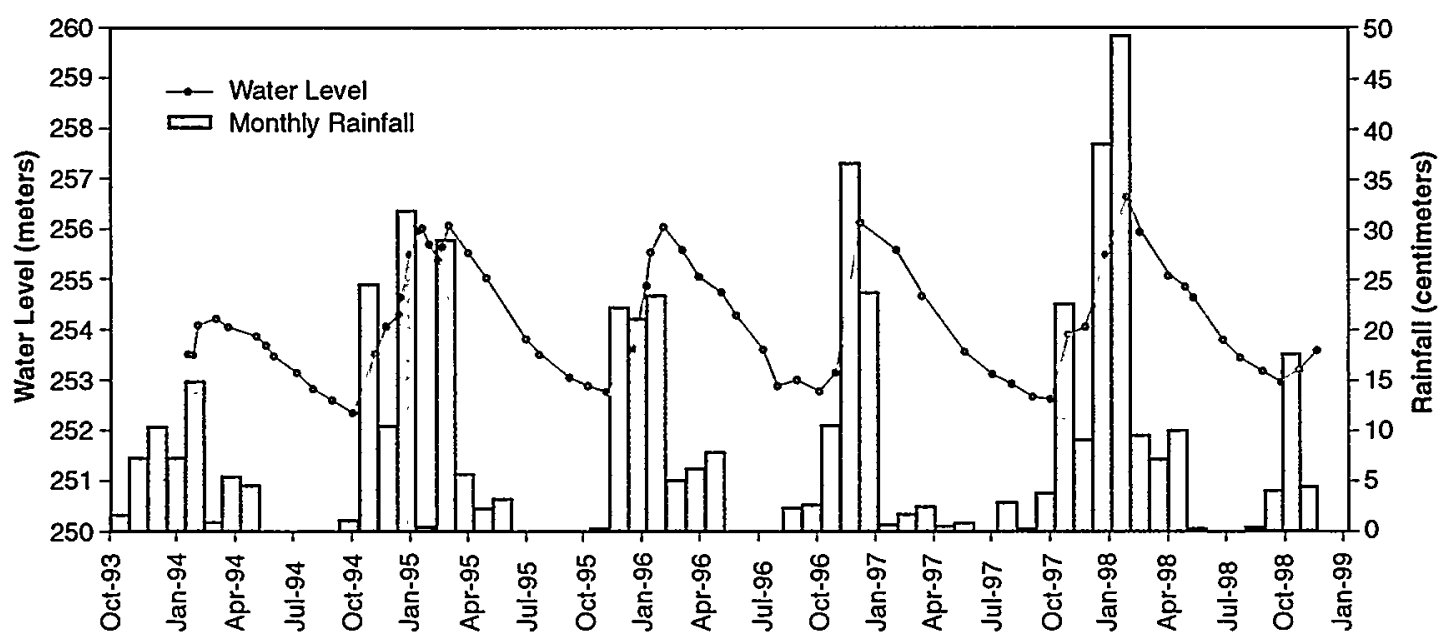

Figure 6-2 Groundwater Fluctuation in Monitoring Well MW53-93-16-69 Versus Rainfall 


\section{$\$ 6.6$ D. Groundwater Quality}

Groundwater samples from monitoring wells are tested for total dissolved solids (TDS), cations, and anions. The TDS concentrations measured in groundwater monitoring wells range from 105 to $4,460 \mathrm{mg} / \mathrm{L}$. Average mineral concentrations for the three primary geologic units are listed in Table 6-1.

\section{$\$ 6.7 \quad$ III. GROUNDWATER MONITORING RESULTS}

In 1998, 20 new monitoring wells were installed, bringing the total in the program to 174 wells. Twenty monitoring wells are located close to the site boundary, and one well is located downgradient from the Laboratory (see Figure 6-3).

Tables 6-2, 6-3, and 6-4 summarize groundwater monitoring results for 1998 . Tables 6-2 and 6-3 summarize the metals results and VOC results, respectively. The tables show the drinking water standard (maximum contaminant level or MCL) for the analyte, ${ }^{4}$ the number of monitoring wells sampled, the number of monitoring wells in which the analyte was detected, and the ranges in concentrations detected. Table 6-4 presents tritium results.

\section{$\$ 6.8 \quad$ IV. GROUNDWATER CONTAMINATION PLUMES}

Based on groundwater monitoring results, eight principal groundwater contamination plumes have been identified on site. The plumes are listed below, and the locations are shown in Figure 6-4:

- VOC plumes: Old Town, Building 71, Building 37, and Building 51/64.

- Freon plume: Building 71.

- Tritium plume: Building 75/77.

- Petroleum hydrocarbon plumes: Buildings 7 and 74.

Contamination was also detected in groundwater in other areas of the site in 1998. Based on current information, however, the extent of contamination in these areas is limited. 
Table 6-1 Long-Term Average Mineral Concentrations in Different Formations

\begin{tabular}{lcccc}
\hline & & \multicolumn{3}{c}{ Average concentration (mg/L) } \\
\cline { 3 - 5 } Parameter & $\begin{array}{c}\text { Drinking water } \\
\text { standard (mg/L) }\end{array}$ & $\begin{array}{c}\text { Orinda } \\
\text { Formation }\end{array}$ & $\begin{array}{c}\text { Moraga } \\
\text { Formation }\end{array}$ & $\begin{array}{c}\text { Great Valley } \\
\text { Formation }\end{array}$ \\
\hline Total dissolved solids & $500^{\mathrm{a}}$ & 921 & 485 & 712 \\
Nitrate & 45 & 24 & 14 & 2.4 \\
Sulfate & 500 & 140 & 30 & 173 \\
Chloride & $250^{\mathrm{a}}$ & 118 & 31 & 49 \\
Bicarbonate & $-\mathrm{b}$ & 510 & 413 & 419 \\
Potassium & $-\mathrm{b}$ & 4.2 & 2.2 & 4.6 \\
Sodium & $-\mathrm{b}$ & 279 & 61 & 119 \\
Magnesium & $-\mathrm{b}$ & 19 & 32 & 33 \\
Calcium & $-\mathrm{b}$ & 33 & 69 & 76 \\
pH & $6.5-8.5 \mathrm{pH}$ units & $8.1 \mathrm{pH}$ units & $7.6 \mathrm{pH}$ units & $7.7 \mathrm{pH}$ units \\
\hline
\end{tabular}

a Indicates secondary standard (aesthetic standard).

${ }^{b}$ No drinking water standard exists for substance.

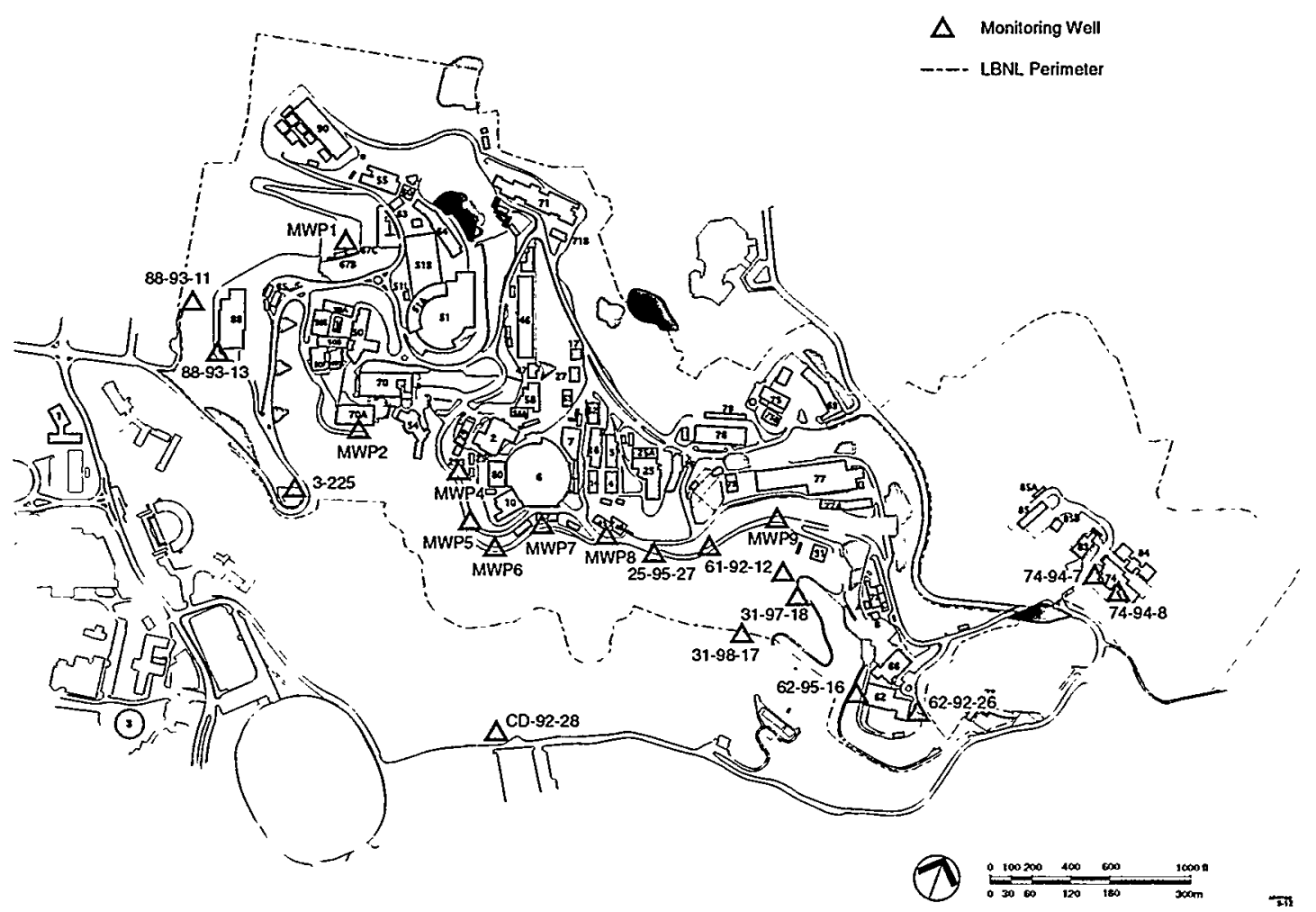

Figure 6-3 Approximate Locations of Monitoring Wells Closest to Berkeley Lab Property Line 
Table 6-2

Metals Detected ${ }^{\mathrm{a}}$ in Groundwater Samples from Monitoring Wells

\begin{tabular}{lccccc} 
Metal & $\begin{array}{c}\text { Number of } \\
\text { wells } \\
\text { sampled }\end{array}$ & $\begin{array}{c}\text { Number of } \\
\text { samples }\end{array}$ & $\begin{array}{c}\text { Number of } \\
\text { wells analyte } \\
\text { detected }\end{array}$ & $\begin{array}{c}\text { Range of } \\
\text { concentrations } \\
(\mu g / L)\end{array}$ & $\begin{array}{c}\text { Drinking water } \\
\text { standard }(\mu g / L)\end{array}$ \\
\hline Antimony & 53 & 55 & 2 & $1-1.1$ & 6 \\
Arsenic & 69 & 71 & 49 & $2.1-82.6$ & 50 \\
Barium & 51 & 53 & 38 & $6.2-442$ & 1,000 \\
Beryllium & 51 & 53 & 1 & 1.3 & 4 \\
Chromium & 53 & 55 & 27 & $1.2-32.2$ & 50 \\
Cobalt & 51 & 53 & 9 & $1-4.5$ & $\mathrm{NS}^{\mathrm{b}}$ \\
Copper & 51 & 53 & 26 & $1-28$ & $1,000^{\mathrm{c}}$ \\
Lead & 51 & 53 & 1 & $3.2-9.2$ & $15^{\mathrm{d}}$ \\
Mercury & 53 & 55 & 1 & 2.3 & 2 \\
Molybdenum & 59 & 61 & 32 & $1.1-404$ & $\mathrm{NS}$ \\
Nickel & 51 & 53 & 12 & $1.5-25.9$ & 100 \\
Selenium & 51 & 53 & 19 & $2.6-160$ & 50 \\
Thallium & 51 & 53 & 1 & 1.5 & 2 \\
Vanadium & 52 & 54 & 35 & $1-66.4$ & $\mathrm{NS}^{\mathrm{b}}$ \\
Zinc & 51 & 53 & 21 & $5.5-50$ & $5,000^{\mathrm{c}}$ \\
\hline Minc & 53 & & &
\end{tabular}

aetals not detected in any samples include cadmium and silver.

${ }^{b} \mathrm{NS}=$ Not specified

c Secondary MCL

d Action level 
Table 6-3 VOCs Detected in Groundwater Samples from Monitoring Wells ${ }^{a}$

\begin{tabular}{|c|c|c|c|}
\hline Analytes detected & $\begin{array}{l}\text { Number of } \\
\text { wells analyte } \\
\text { detected }\end{array}$ & $\begin{array}{c}\text { Range of } \\
\text { concentrations } \\
(\mu g / L)\end{array}$ & $\begin{array}{l}\text { Drinking water } \\
\text { standard }(\mu g / L)\end{array}$ \\
\hline \multicolumn{4}{|l|}{ Aromatic or nonhalogenated hydrocarbons } \\
\hline Benzene & 2 & $1.5-43.5$ & 1 \\
\hline Bis(2-ethylhexyl)phthalate & 1 & 18 & $N^{b}$ \\
\hline sec-Butylbenzene & 1 & 3.2 & $N S^{b}$ \\
\hline 1,2-Dichlorobenzene & 1 & 0.59 & $N S^{b}$ \\
\hline 1,4-Dichlorobenzene & 2 & $0.6-0.83$ & $N^{b}$ \\
\hline p-lsopropyltoluene & 2 & $1.1-2.8$ & $N^{b}$ \\
\hline Toluene & 5 & $0.58-2$ & 150 \\
\hline 1,2,4-Trimethylbenzene & 1 & 1.2 & $N S^{b}$ \\
\hline 1,3,5-Trimethylbenzene & 1 & 1.1 & $N S^{b}$ \\
\hline \multicolumn{4}{|l|}{ Halogenated hydrocarbons } \\
\hline Bromoform & 2 & $0.64-1.3$ & $N S^{b}$ \\
\hline Carbon tetrachloride & 21 & $0.87-2,400$ & 0.5 \\
\hline Chloroethane & 1 & 0.97 & $N S^{b}$ \\
\hline Chloroform & 42 & $0.51-256$ & 100 \\
\hline 1,1-Dichloroethane & 30 & $0.52-9,110$ & 5 \\
\hline 1,2-Dichloroethane & 4 & $1.4-56.3$ & 0.5 \\
\hline 1,1-Dichloroethene & 39 & $0.55-2,780$ & 6 \\
\hline cis-1,2-Dichloroethene & 53 & $0.54-1,200$ & 6 \\
\hline trans-1,2-Dichloroethene & 12 & $1-64.7$ & 10 \\
\hline Dichlorodifluoromethane (Freon-12) & 1 & 0.64 & $N^{b}$ \\
\hline 1,2-Dichlorotrifluoroethane(Freon-123A) & 5 & $1.1-3.4$ & $N S^{b}$ \\
\hline Methylene chloride & 1 & 120 & 5 \\
\hline Methyl tert-butyl ether & 1 & 0.62 & $N^{b}$ \\
\hline 1,1,1,2-Tetrachloroethane & 2 & $13-19$ & $N S^{b}$ \\
\hline 1,1,2,2-Tetrachloroethane & 1 & 0.59 & 1 \\
\hline Tetrachloroethene & 54 & $0.51-54,900$ & 5 \\
\hline $1,1,1$-Trichloroethane & 18 & $0.53-24,000$ & 200 \\
\hline 1,1,2-Trichloroethane & 3 & $0.64-7.1$ & 5 \\
\hline Trichloroethene & 78 & $1-43,600$ & 5 \\
\hline Trichlorofluoromethane (Freon-11) & 2 & $0.97-3.5$ & 150 \\
\hline 1,1,2-Trichlorotrifluoroethane (Freon 113) & 9 & $0.51-43.5$ & 1,200 \\
\hline Vinyl chloride & 14 & $0.87-104$ & 0.5 \\
\hline
\end{tabular}

a 475 samples taken from 165 wells during the year, except for Bis(2-ethylhexyl)phthalate (1 sample), Freon-123A ( 416 samples from 133 wells), and Methyl tert-butyl ether ( 427 samples from 149 wells).

b NS $=$ Not specified 


\begin{tabular}{|c|c|c|c|c|}
\hline Table 6-4 & Tritium Detecte & in Groundwe & Samples from Mc & nitoring Wells \\
\hline Well number & $\begin{array}{c}\text { January-March } \\
(B q / L)\end{array}$ & $\begin{array}{l}\text { April-June } \\
\quad(\mathrm{Bq} / \mathrm{L})\end{array}$ & $\begin{array}{c}\text { July-September } \\
(\mathrm{Bq} / \mathrm{L})\end{array}$ & $\begin{array}{c}\text { October-December } \\
\text { (Bq/L) }\end{array}$ \\
\hline MW91-4 & 33 & $\mathrm{NS}^{\mathrm{C}}$ & 27 & $\mathrm{NS}^{\mathrm{C}}$ \\
\hline MW91-5 & 252 & $\mathrm{NS}^{\mathrm{c}}$ & 50 & $N^{c}$ \\
\hline MW91-6 & 208 & $\mathrm{NS}^{\mathrm{c}}$ & 68 & NSc \\
\hline $75-92-23$ & 142 & $N^{c}$ & 37 & $\mathrm{NS}^{\mathrm{c}}$ \\
\hline $75 B-92-24$ & 124 & $\mathrm{NS}^{\mathrm{C}}$ & 188 & NSc \\
\hline $75-97-5$ & $\mathrm{NS}^{\mathrm{c}}$ & $\mathrm{NS}^{\mathrm{c}}$ & $536,455^{d}$ & $807,999,1,043^{d}$ \\
\hline $75-97-7$ & 46 & 22 & 22 & 50 \\
\hline $69-97-8$ & $<11$ & $\mathrm{NS}^{\mathrm{c}}$ & $<11,<11^{d}$ & $17,<11$ \\
\hline $69-97-21$ & 42,70 & 20,19 & 14 & $16,18^{d}$ \\
\hline $75-98-14$ & NSc & $N S^{c}$ & $N^{c}$ & 24 \\
\hline MW76-1 & $<11$ & $N^{c}$ & 12 & NSc \\
\hline $76-93-6$ & 67 & NSc & 58 & NSc \\
\hline $76-93-7$ & $<11$ & $N^{c}$ & $<11$ & $20,<11$ \\
\hline $78-97-20$ & 232 & 129 & 81 & 133 \\
\hline MW91-2 & 21 & $N S^{c}$ & 30 & NSc \\
\hline $77-94-6$ & 572 & 293 & 202 & $370,433^{d}$ \\
\hline $77-97-9$ & 443 & 432 & 241 & 356 \\
\hline $77-97-11$ & 275 & 81 & $98,102^{d}$ & $179,208^{d}$ \\
\hline $31-97-17$ & 47 & 55 & 33 & 43 \\
\hline MWP-7 & $<11$ & $<11$ & $<11$ & $26,<11$ \\
\hline
\end{tabular}

${ }^{a}$ Wells without detectable results in all quarters of sampling include MW90-3, 46A-92-15, 71-93-1, 71-95-1, 69A-92-22, 75-96-20, 75-97-6, 75-98-15, 76-92-25, MW91-1, MWP-9, MWP-10, 77-92-10, 61-92-12, 77-93-8, 77-94-5, 31-97-18, 31-98-17, MWP-2, OW3-225, MWP-8, 52-94-10, 52-95-2, 74-94-7, 62-92-26, 62-92-27, MWP-1, MWP-4, MWP-5, MWP-6, 37-92-6, and CD-92-28.

${ }^{b}$ For comparison, the drinking water standard determined by California Department of Health Services is $740 \mathrm{~Bq} / \mathrm{L}$ (20,000 pCi/L).

c NS $=$ Not sampled

d Duplicate sample 


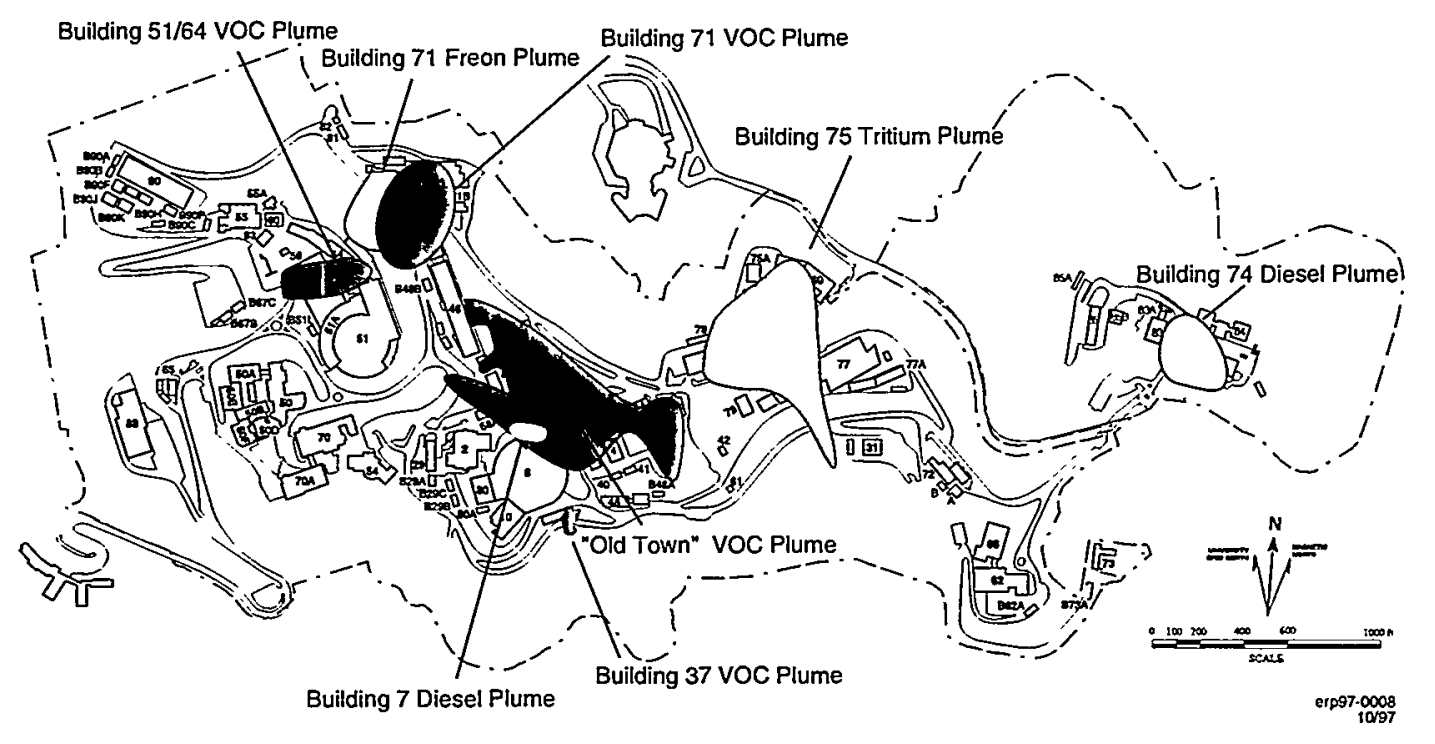

Figure 6-4 Groundwater Contamination Plumes (December 1998)

\section{$\$ 6.9 \quad$ A. VOC Plumes}

Covering the area of Buildings 7, 53, 27, and 58A and the slope west of Building 53, the Old Town VOC plume is the most extensive plume at Berkeley Lab. This plume is defined by the presence of tetrachloroethene (PCE), trichloroethene (TCE), and lower concentrations of other halogenated hydrocarbons, including 1,1-dichloroethene (1,1DCE), cis-1,2-DCE, 1,1-dichloroethane (1,1-DCA), 1,2-DCA, 1,1,1-trichloroethane (1,1,1-TCA), 1,1,2-TCA, carbon tetrachloride, and vinyl chloride, several of which are products of PCE and TCE degradation. The maximum concentration of total halogenated hydrocarbons detected in 1998 in groundwater samples collected from wells monitoring the Old Town VOC plume was $97,800 \mu \mathrm{g} / \mathrm{L}$, which primarily consisted of PCE $(54,900 \mu \mathrm{g} / \mathrm{L})$, TCE $(39,700 \mu \mathrm{g} / \mathrm{L})$ and carbon tetrachloride $(2,400 \mu \mathrm{g} / \mathrm{L})$. Figure $6-5$ shows the areal extent of VOCs in groundwater in the Old Town area.

The presence of the maximum VOC concentrations north of Building 7 suggests that the primary source of the Old Town VOC plume was apparently an abandoned sump located between Buildings 7 and 7B. The sump was discovered and its contents removed in 1992. The sump was removed in 1995 after underground utility lines that crossed the sump were relocated. Other less significant source areas for groundwater contamination are indicated by relatively high concentrations of halogenated hydrocarbons detected in groundwater samples from monitoring wells west of Building 16, east of Building 52, and west of Building 25A. The sources of the contamination detected in those wells have not been identified. The contaminated groundwater from these sources flows westward, where it intermixes with the main Old Town plume. 


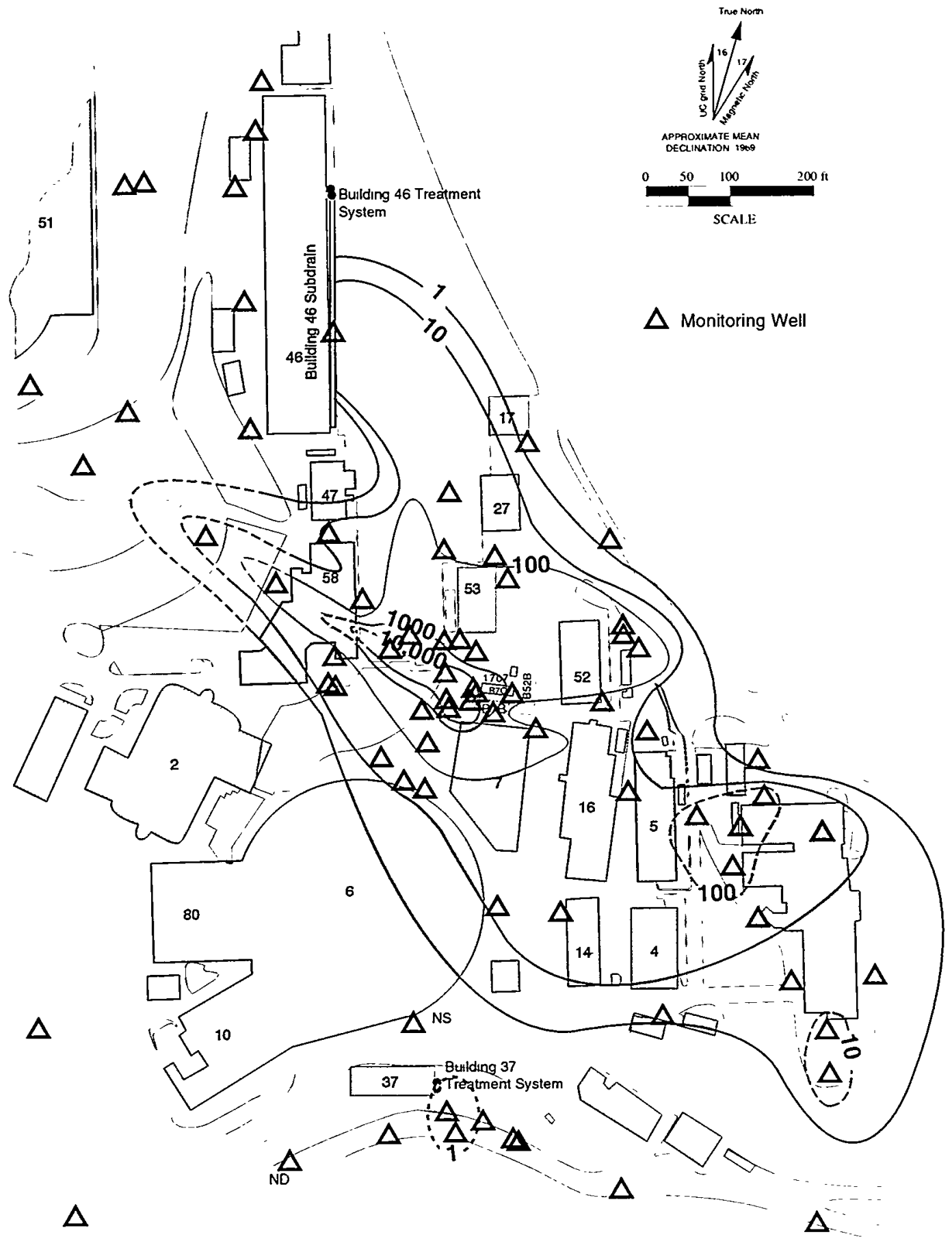

Figure 6-5 Groundwater Contamination (Total Halogenated Hydrocarbons in $\mu \mathrm{g} / \mathrm{L}$ ) in Old Town Area (December 1998) 
Four interim corrective measures (ICMs) have been instituted to manage the Old Town VOC Plume (see §6.13):

- A groundwater collection trench was installed immediately downgradient from the former Building 7 sump, the source of the groundwater contamination;

- A subdrain located east of Building 46 intercepts the northern lobe of the plume;

- A groundwater collection trench was installed west of Building 58 to intercept the southern lobe of the plume; and

- A groundwater collection trench was installed on the slope east of Building 58, in an area where high VOC concentrations had been detected in soil gas and groundwater.

A second plume of VOC-contaminated groundwater, the Building 51/64 VOC Plume, extends from the southeast corner of Building 64, under Buildings 64 and 51B. This plume is defined by the presence of 1,1,1-TCA, 1,1-DCA, 1,1-DCE, PCE, TCE, and lower concentrations of other halogenated hydrocarbons. Halogenated hydrocarbons were detected in 1998 at a maximum total concentration of $822,400 \mu \mathrm{g} / \mathrm{L}$ in a water sample from a boring in the source area of the plume. The maximum concentration of total halogenated hydrocarbons detected in 1998 in samples collected from groundwater monitoring wells in the Building 51/64 area was $41,200 \mu \mathrm{g} / \mathrm{L}$. The contaminants primarily consisted of 1,1,1-TCA $(24,000 \mu \mathrm{g} / \mathrm{L})$ and 1,1-DCA $(9,100 \mu \mathrm{g} / \mathrm{L})$. Figure 6-6 shows the areal extent of VOCs in groundwater in the Building 51/64 area.

Other VOC plumes have been identified south of Building 71 (Building 71 VOC plume) and east of Building 37 (Building 37 VOC plume). These plumes cover less area than the Old Town plume, and fewer contaminants have been detected. The sources of these contaminant plumes are not known.

The Building 71 VOC plume is defined by the presence of halogenated hydrocarbons, predominantly PCE, TCE, cis-1,2-DCE, 1,1-DCA, 1,1,1-TCA, and vinyl chloride. The maximum concentration of total halogenated hydrocarbons detected in wells monitoring the plume, $262 \mu \mathrm{g} / \mathrm{L}$, was detected in a monitoring well installed southwest of Building 71B to help locate the source of the plume. Contaminated groundwater from the plume is discharged continuously through five subhorizontal drains (hydraugers). Effluent from these hydraugers is collected and treated before being released under permit to the sanitary sewer.

The Building 37 VOC plume is defined by the presence of halogenated hydrocarbons, primarily PCE and TCE in monitoring wells MWP-7 and MW37-92-6. There has been a decreasing trend in VOC concentrations detected in these two wells since January 1994, when pumping groundwater for plume management was initiated. The maximum concentration of total halogenated hydrocarbons detected in wells monitoring the plume in 1998 was $8.9 \mu \mathrm{g} / \mathrm{L}$.

\section{$\$ 6.10$ B. Freon Plume}

High concentrations of freon-113 were detected in groundwater south of Building 71 in 1993 and 1994. The source of freon-113 was most likely past spills from the Linear Accelerator Cooling Unit located in Building 71. The cooling unit is no longer operational. Concentrations of freon-113 have decreased from $8,984 \mu \mathrm{g} / \mathrm{L}$ in 1994 to 


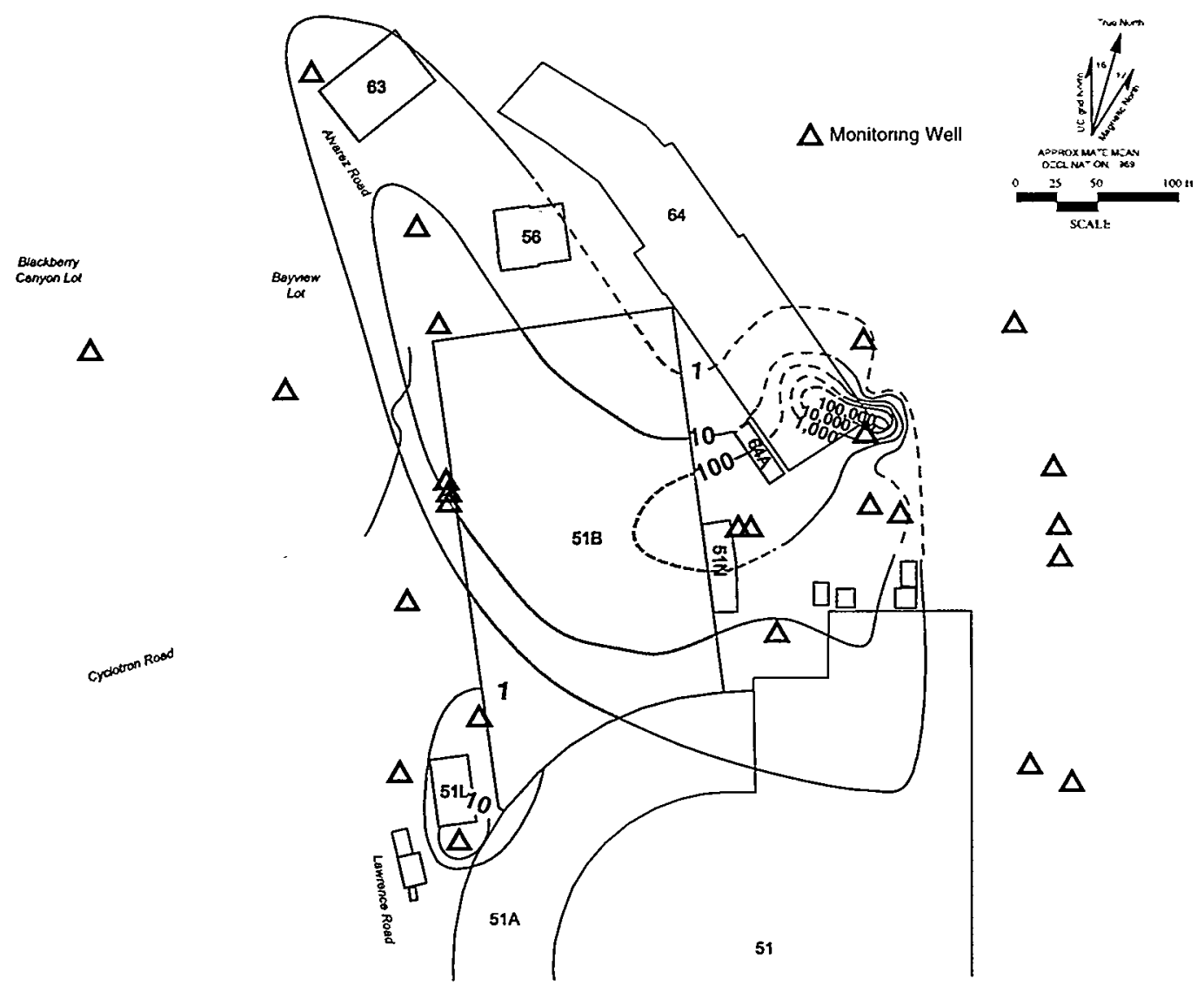

Figure 6-6 Groundwater Contamination (Total Halogenated Hydrocarbons in $\mu \mathrm{g} / \mathrm{L}$ ) at Building 51/64 VOC Plume (December 1998)

$43.5 \mu \mathrm{g} / \mathrm{L}$ in June 1998. The MCL for freon-113 is $1,200 \mu \mathrm{g} / \mathrm{L}$. Contaminated groundwater from the plume is continuously discharged through two hydraugers. Effluent from these hydraugers is collected and treated before being released under permit to the sanitary sewer.

\section{$\S 6.11$ C. Tritium Plume}

The tritium plume covers the areas of Buildings $31,75,76,77$, and 78 . The source of the tritium is the National Tritium Labeling Facility at Building 75. The maximum concentration of tritium detected in monitoring wells in 1998 was $1,043 \mathrm{~Bq} / \mathrm{L}$ $(28,200 \mathrm{pCi} / \mathrm{L})$, which is above the drinking water standard of $740 \mathrm{~Bq} / \mathrm{L}(20,000 \mathrm{pCi} / \mathrm{L}) .^{5}$ Tritium has been detected above the drinking water standard in only one monitoring well.

\section{$\$ 6.12$ D. Petroleum Hydrocarbon Plumes}

Monitoring wells have been installed at or downgradient from two abandoned and seven removed underground fuel storage tanks (USTs). Figure 6-7 shows the 


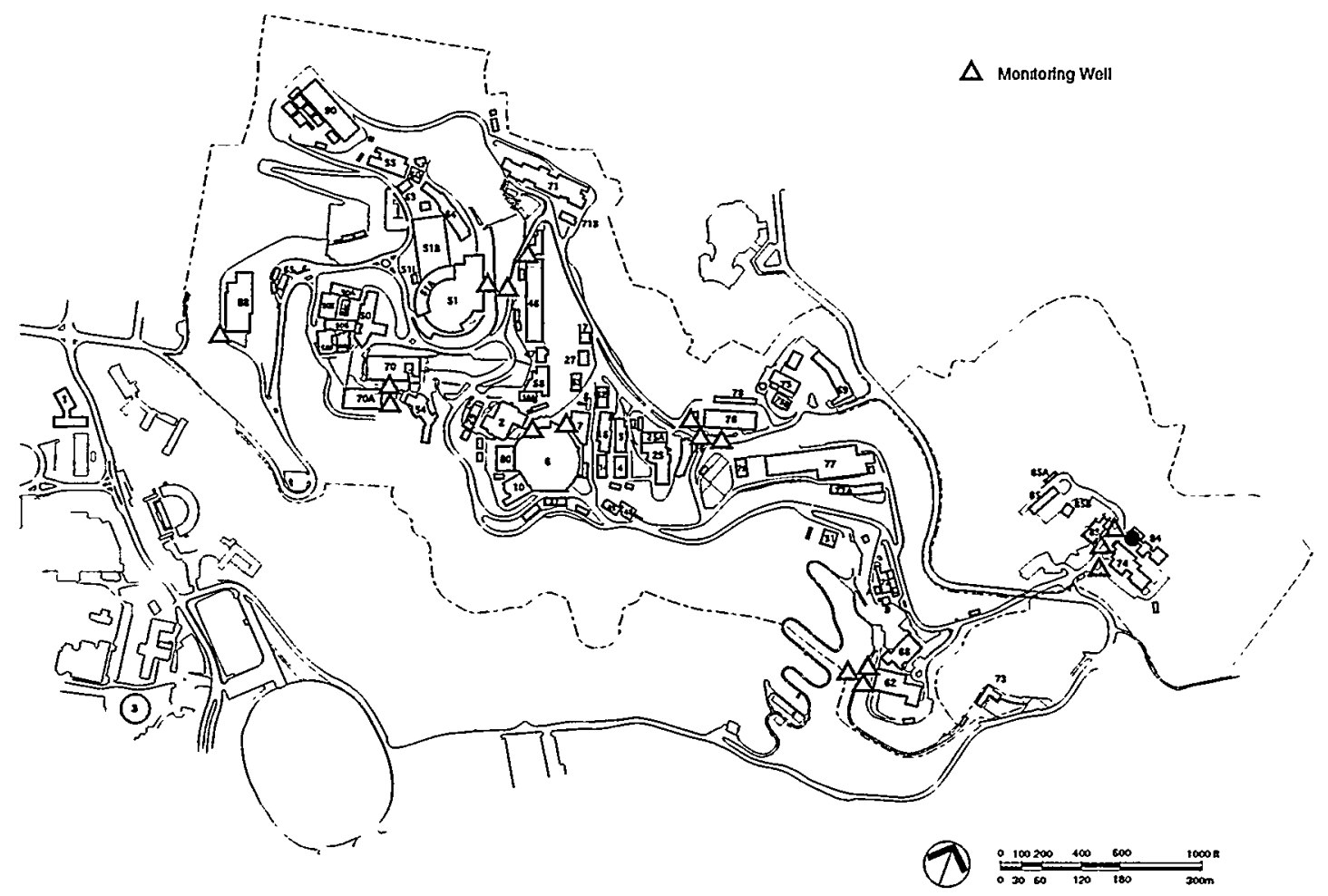

Figure 6-7 Approximate Locations of Monitoring Wells Associated with Underground Storage Tanks

approximate locations of these wells. The maximum concentrations of total petroleum hydrocarbons (TPH) detected at these sites in 1998 are listed in Table 6-5.

The only UST site where aromatic hydrocarbons were detected was the Building 7E former kerosene tank. The plume (Building 7 Diesel Plume) is located north of Building 6. No BTEX components (i.e., benzene, toluene, ethyl benzene, xylenes) were detected at UST sites. A dual phase (groundwater and soil vapor) extraction and treatment system was installed at the location of the Building $7 \mathrm{E}$ former UST as an interim corrective measure.

Methyl tertiary butyl ether (MTBE) was detected in one monitoring well at a concentration of $0.62 \mu \mathrm{g} / \mathrm{L}$. The US/EPA Drinking Water Advisory for MTBE is 20 to $40 \mu \mathrm{g} / \mathrm{L}$.

\section{$\$ 6.13$ V. INTERIM CORRECTIVE MEASURES}

Interim corrective measures are used to remediate contaminated media or prevent movement of contamination, where the presence or movement of contamination poses a threat to human health or the environment. Throughout the RCRA corrective action 
Table 6-5 Total Petroleum Hydrocarbon Concentrations at UST Sites

\begin{tabular}{|c|c|c|c|}
\hline UST location & Status & $\begin{array}{c}\text { Present or } \\
\text { previous contents }\end{array}$ & $\begin{array}{c}\text { Maximum } \\
\text { concentration }(\mu g / L)\end{array}$ \\
\hline Building 51 & Removed & Diesel & $N^{a}$ \\
\hline Building 70A & Removed & Diesel & $N D^{a}$ \\
\hline Building 62 & Removed & Diesel & NDa \\
\hline Building 74 & Removed & Diesel & $T P H-D^{b}=840$ \\
\hline Building 76 & Removed & Diesel & $\mathrm{TPH}-\mathrm{D}^{\mathrm{b}}=440$ \\
\hline Building 76 & Removed & Gasoline & $\mathrm{TPH}-\mathrm{G}^{\mathrm{C}}=75$ \\
\hline Building 7E & Removed & Kerosene & $\mathrm{TPH}-\mathrm{D}^{\mathrm{b}}=63,000^{e}$ \\
\hline Building 88 & Abandoned & Diesel & ND \\
\hline Building 46A & Abandoned & Gasoline & $\mathrm{NS}^{\mathrm{d}}$ \\
\hline
\end{tabular}

process, Berkeley Lab has conducted the following interim corrective measures in consultation with regulatory agencies:

- Removing or controlling sources of contamination;

- Stopping discharge of contaminated water to surface waters;

- Eliminating potential pathways that could contaminate groundwater; and

- Preventing further migration of contaminated groundwater.

\section{$\$ 6.14$ A. Source Removal or Control}

The need for interim corrective measures is evaluated if (1) the contaminant concentrations pose a potential threat to human health or the environment or (2) leaching of contaminants from soil may affect groundwater. Several sources of contamination have been removed at the Laboratory, including the following in 1998:

- Approximately 80 cubic meters (100 cubic yards) of contaminated soil were excavated from the area of the Building 7 former plating shop in August 1998. Soil contamination consisted of metals, PCBs, and VOCs.

- Approximately 30 cubic meters (40 cubic yards) of PCB contaminated soil were excavated from an area north of Building 17 in October 1998.

- Highly contaminated soil and groundwater near the source location (the former Building 7 sump) are a continuing source of contamination for the Old Town plume. To control the source of contamination, the Laboratory constructed a groundwater collection trench immediately downgradient from the former sump location in 1996. Contaminated groundwater is extracted from the collection trench and treated. The treatment system removed approximately $18 \mathrm{~kg}$ of VOCs (consisting primarily of PCE, TCE, and carbon tetrachloride) from the groundwater in 1998. 
- A dual phase (groundwater and soil vapor) extraction and treatment system was installed at the location of the Building 7E former UST to remove contaminants from the soil and groundwater. Pumping and treating groundwater started on September 18, 1998, and vapor extraction and treatment on October 20, 1998. Approximately $8.5 \mathrm{~kg}$ of contaminant mass was removed by the vapor extraction system in 1998.

\section{\$6.15 B. Preventing Discharge of Contamination to Surface Waters}

Slope stability is a concern at Berkeley Lab because of the geology and topography of the site. Free-flowing hydraugers were installed in the past to dewater and stabilize areas of potential landslides. Effluent from these hydraugers generally enters the creeks. Some of the hydraugers intercept contaminated groundwater. To prevent the discharge of the contaminated groundwater to the creeks, Berkeley Lab installed a system to collect and treat the hydrauger effluent where the water was contaminated with VOCs.

\section{\$6.16 C. Preventing Further Migration of Contaminated Groundwater}

As interim corrective measures to control groundwater plumes that could migrate off site or contaminate surface water, Berkeley Lab is capturing and treating contaminated groundwater using extraction wells and subdrains. In addition, two groundwater collection trenches were constructed to prevent further migration of the Old Town plume. The first trench was installed west of Building 53 and the second at the base of the slope west of Building 58.

\section{$\$ 6.17$ D. Treatment Systems}

As described above, Berkeley Lab is using extraction wells and subdrains to control groundwater plumes that could migrate off site or contaminate surface water. Seven granular-activated carbon treatment systems have been installed. The treated water is recycled for industrial use on site, released to the sanitary sewer in accordance with Berkeley Lab's treated groundwater discharge permit from EBMUD, ${ }^{6}$ or recirculated to flush contaminants from the subsurface. Table 6-6 lists both the volume of contaminated groundwater treated by each system in 1998 and the total volume treated since the treatment systems were first placed in operation. 
Table 6-6 Treatment of Contaminated Groundwater

\begin{tabular}{|c|c|c|c|}
\hline Source of contamination & Treatment system & $\begin{array}{c}\text { Volume of water } \\
\text { treated in } 1998 \\
\text { (liters) }^{\star}\end{array}$ & $\begin{array}{c}\text { Total volume } \\
\text { treated } \\
\text { (liters) }\end{array}$ \\
\hline Building 37 VOC plume & Building 37 & 975,247 & $3,284,509$ \\
\hline Old Town VOC plume & Building 46 & $5,613,515$ & $22,090,354$ \\
\hline $\begin{array}{l}\text { Building } 71 \text { VOC plume and } \\
\text { water collected from purging } \\
\text { monitoring wells }\end{array}$ & Building 51 firetrail & 566,861 & 892,700 \\
\hline $\begin{array}{l}\text { VOC-contaminated hydrauger } \\
\text { effluent }\end{array}$ & Building 51 hydraugers & $4,002,021$ & $32,396,875$ \\
\hline Building 51 subdrain system & Building 51 sump & $1,682,917$ & $3,247,030$ \\
\hline Old Town VOC plume & Building 7 trench & $2,482,343$ & $3,512,703$ \\
\hline $\begin{array}{l}\text { Building } 6 \text { former underground } \\
\text { storage tank }\end{array}$ & Building 6 bioventing & 400,033 & 400,033 \\
\hline Total volume treated & & $15,722,935$ & $65,824,204$ \\
\hline
\end{tabular}

*1 liter $=0.264$ gallons 


\section{7 \\ Sanitary Sewer}

I. BACKGROUND $\$ 7.1$

Figure 7-1: Sanitary Sewer System

II. WASTEWATER DISCHARGE PROGRAM $\$ 7.2$

III. SANITARY SEWER RESULTS

A. Hearst and Strawberry Sewer Outfalls $\$ \mathbf{\$ 7 . 3}$

1. Nonradiological Monitoring $\$ 7.4$

Figure 7-2: Concentration of Metals in Hearst and Strawberry Sewer Water Samples

2. Radiological Monitoring $\$ 7.5$

Figure 7-3: Total Radioisotope Amounts Discharged to Sewers

Figure 7-4: Annual Releases of Tritium to Sewers (1994-1998)

B. Building 25 Photo Fabrication Shop Wastewater \$7.6

C. Building 77 Ultra-High Vacuum Cleaning Facility Wastewater $\$ 7.7$

D. Treated Hydrauger and Extraction Well Discharge $\$ \$ 7.8$

\section{$\$ 7.1 \quad$ I. BACKGROUND}

The Laboratory's sanitary sewer system is based on gravity flow and discharges through one of two monitoring stations: Hearst or Strawberry (see Figure 7-1):

- Hearst Station, located at the head of Hearst Avenue below Berkeley Lab, monitors discharges from the western and northern portion of the site. The monitoring site is located just before the Laboratory's sanitary sewer system connects to the City of Berkeley sewer main.

- Strawberry Station is located next to Centennial Drive in Strawberry Canyon and monitors discharges from the eastern and southern parts of the Laboratory. Beyond the monitoring station, this section of the discharge system first ties into University-owned piping and then into the City of Berkeley system. Because of the design of the network, Strawberry monitoring station also receives effluent from several UC Berkeley campus facilities, which are located above the 


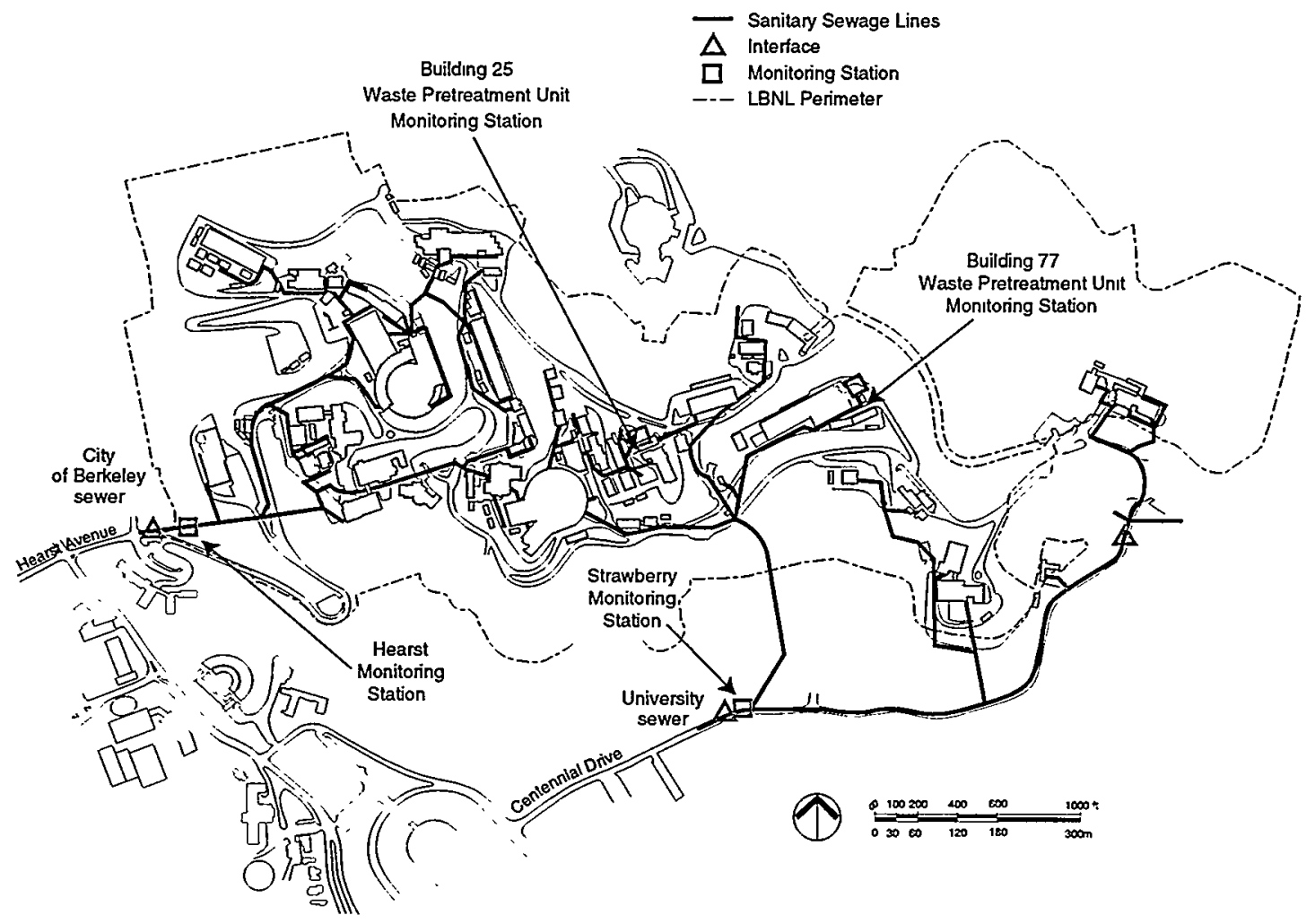

Figure 7-1 Sanitary Sewer System

Laboratory and are separate from the main UC Berkeley campus (i.e., Lawrence Hall of Science, Space Sciences Laboratory, Mathematical Sciences Research Institute, Animal Research Facility, and the Botanical Gardens).

Self-monitoring of wastewater discharge within Berkeley Lab also occurs at Buildings 25 and 77 and at groundwater treatment units (see Table 6-6), according to the terms of their respective East Bay Municipal Utility District (EBMUD) permits. ${ }^{1}$

\section{$\$ 7.2$ II. WASTEWATER DISCHARGE PROGRAM}

Berkeley Lab currently has four wastewater discharge permits issued by EBMUD: one for general sitewide discharges, two for the metal finishing operations found in Buildings 25 and 77, and one for the discharge of treated groundwater from hydraugers. EBMUD renews the site's wastewater discharge permits annually in September, except for the treated groundwater permit, which is granted for two years. EBMUD is the local Publicly Owned Treatment Works that regulates all industrial discharges to its treatment facilities.

As in previous years, the Laboratory's 1998-1999 permit required monitoring of wastewater discharge four times per year and metals analysis once per year at times specified in the permit. EBMUD continues to perform unannounced monitoring four times per year. There were no changes in discharge limits or other permit requirements. All sampling results are presented in volume II. 


\section{SANITARY SEWER RESULTS}

\section{$\$ 7.3 \quad$ A. Hearst and Strawberry Sewer Outfalls}

Sanitary sewer discharge monitoring is divided into two major types: nonradiological and radiological. Nonradiological monitoring is generally termed "self-monitoring" and is mandated in the wastewater discharge permits granted to Berkeley Lab by EBMUD. Sitewide samples are always analyzed for $\mathrm{pH}$, methylene chloride, total suspended solids, and chemical oxygen demand, with additional analyses for metals required once during the permit year.

Radiological monitoring is required by Department of Energy guidance ${ }^{2}$ and orders, ${ }^{3}$ but it also ensures compliance with the radiological limits given in the California Code of Regulations. ${ }^{4}$ California regulations now incorporate by reference the applicable federal regulations 5 and associated discharge limits.

Analysis is performed by a state-certified outside contract laboratory. Results are compared against the discharge limits for each parameter given in the permits, and selfmonitoring reports are submitted to EBMUD following permit requirements.

\section{$\$ 7.4$ 1. Nonradiological Monitoring}

Four nonradiological self-monitoring samples were taken from the Hearst and Strawberry outfalls during 1998. All results were well within discharge limits, as were all measurements made by EBMUD in its independent samplings. Analysis for metals was required for only one of the four samples and was carried out at the November sampling. Most metals were not detected above detection limits in either Hearst or Strawberry outfalls.

Although no specific limit for iron is given in the permit, an EBMUD sampling showed an elevated level with respect to the thresholds given in Ordinance 311 (EBMUD Wastewater Control Ordinance). In voluntary response, in the July sampling Berkeley Lab analyzed for iron and found levels at about $2 \%$ of the ordinance limits. Figure 7-2 shows the metals results for the 1998 sampling as a percentage of permit discharge limits.

Methylene chloride was not detected at either Hearst or Strawberry Station during the four samplings conducted this year. According to the permit, the $\mathrm{pH}$ level must remain at no less than 5.5; all results for 1998 were above 8.0. Total suspended solids and chemical oxygen demand are measured to determine wastewater strength, which forms the basis for EBMUD's charges to the Laboratory for wastewater treatment. Starting with the 1997-1998 permit, Berkeley Lab is expected to estimate the average and maximum wastewater strength for the coming year in its permit application, and these then become the permit limits. The estimates for 1998 met EBMUD's standard. 


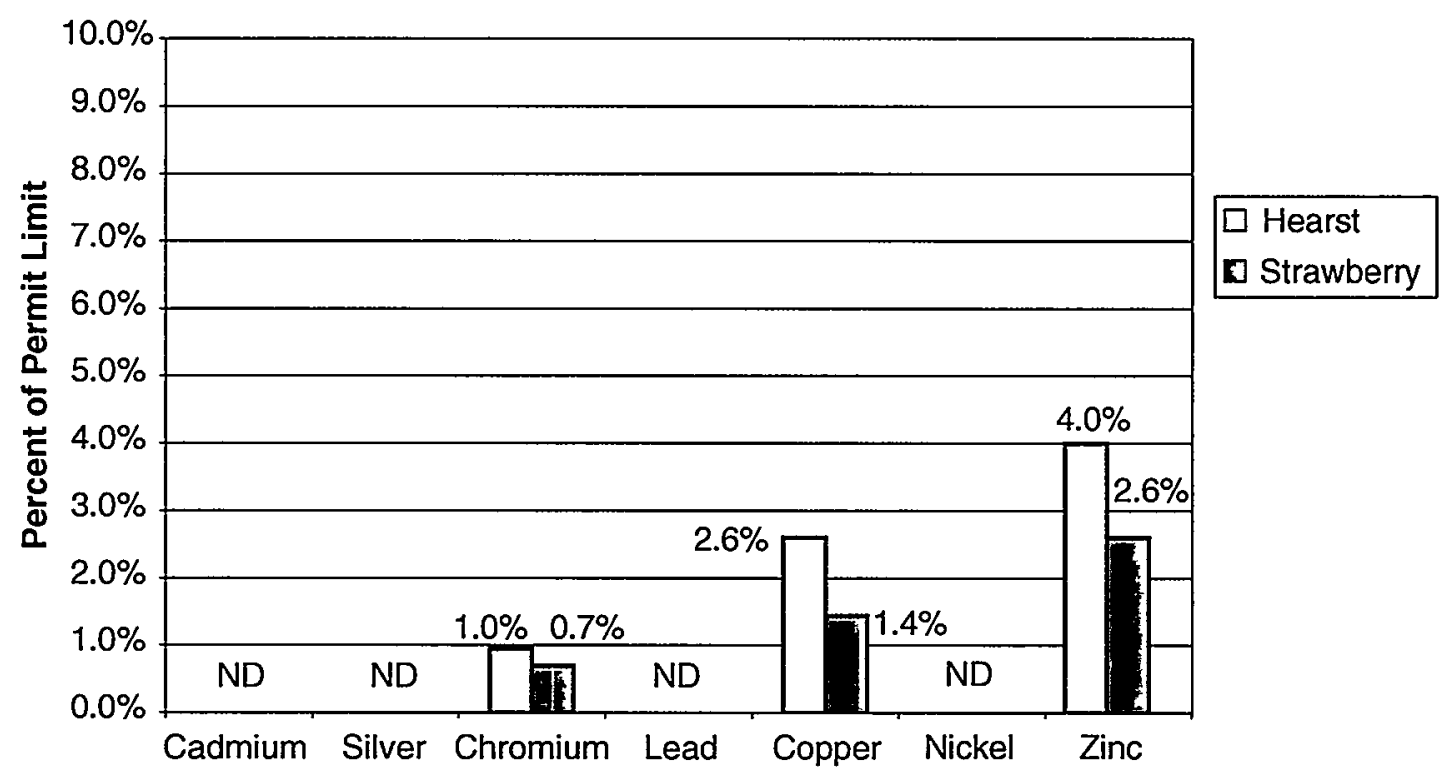

Figure 7-2 Concentration of Metals in Hearst and Strawberry Sewer Water Samples

\section{$\$ 7.5 \quad 2 . \quad$ Radiological Monitoring}

The Hearst and Strawberry sewer outfalls are sampled continuously by automatic equipment that collects samples at half-hour intervals. The composite samples are collected biweekly for subsequent analysis of gross alpha, gross beta, iodine-125, and tritium by a state-certified laboratory. Some split samples were occasionally analyzed by a third laboratory for additional quality control purposes.

The federal ${ }^{5}$ and state ${ }^{4}$ regulatory limits are based on total amounts released per year. For tritium, this amount is $1.9 \times 10^{11} \mathrm{~Bq}$ (5 curies) per year. The limit for all other radioisotopes is a combined $3.7 \times 10^{10} \mathrm{~Bq}(1$ curie) per year. Total amounts of monitored radioisotopes in Berkeley Lab's sewer wastewater for 1998 are summarized in Figure 7-3.

Alpha emitters, which can potentially come from transuranic and heavy-element research, were never seen at either Hearst or Strawberry Station. Beta emitters, including iodine-125 from biomedical research, were detected in both sewers at low levels, generally with less at Strawberry than at Hearst. The highest readings for the year appear to have occurred at Hearst at the beginning of November and toward the end of December. For individual results, see the data tables in the appendix.

Tritium was generally below the minimum detectable activity at Hearst but was usually seen at Strawberry. The total yearly discharge of tritium in wastewater was $1.7 \times$ $10^{10} \mathrm{~Bq}(0.46 \mathrm{Ci})$, and the total for other radioisotopes was $4.0 \times 10^{8} \mathrm{~Bq}(0.011 \mathrm{Ci})$. Tritium was slightly above last year's values, while the total for other radioisotopes remained about the same. All values, however, were well below allowable limits. For 


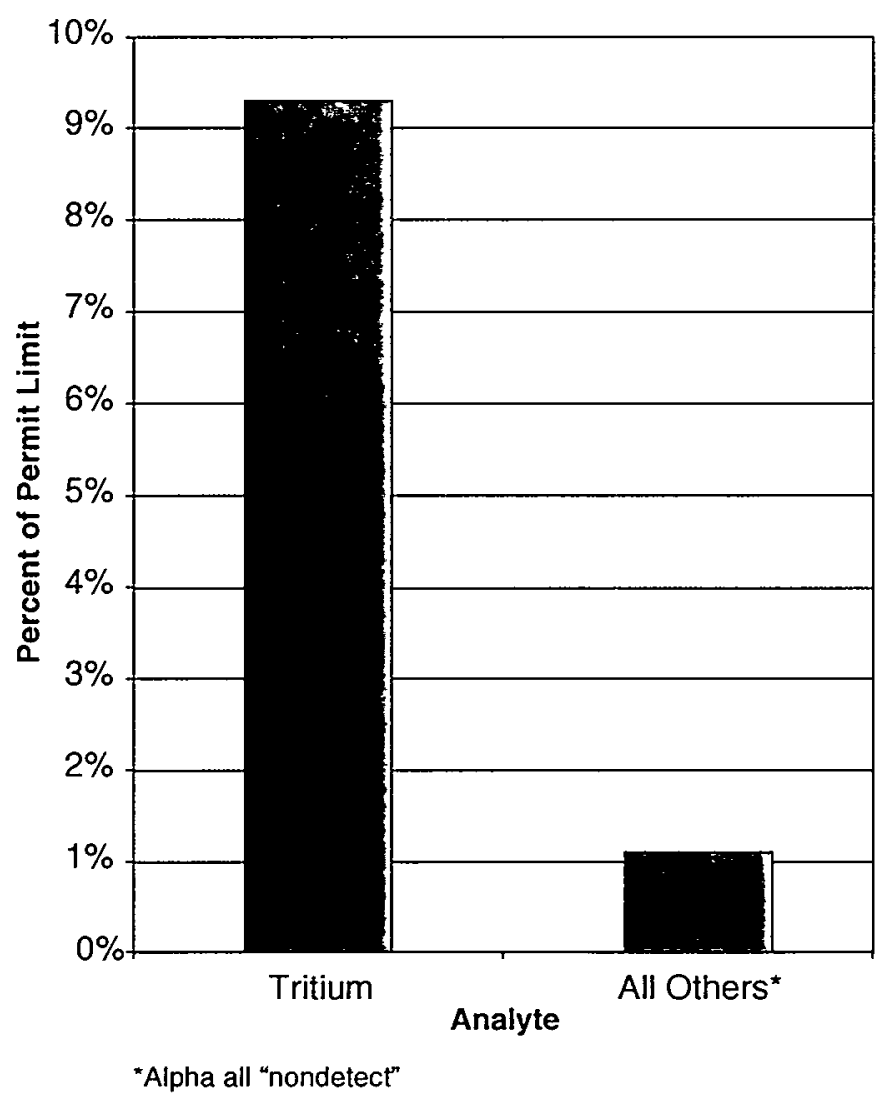

Figure 7-3 Total Radioisotope Amounts Discharged to Sewers

example, tritium was only $9 \%$ of the allowable federal and state limit, while all other isotopes together were less than $2 \%$ of their limit.

Figure 7-4 trends the total amount of tritium released to Berkeley Lab's sewers over the last five years. Results vary from $4.4 \times 10^{9}$ to $1.7 \times 10^{10} \mathrm{~Bq}$, which is about $2 \%$ to $9 \%$ of the permitted level.

\section{$\$ 7.6 \quad$ B. Building 25 Photo Fabrication Shop Wastewater}

The Photo Fabrication Shop in Building 25 manufactures electronic printed circuit boards and screen print nomenclature on panels to support the needs of Berkeley Lab research and operations. Wastewaters containing metals and other hazardous materials from these operations are routed to a fixed treatment unit (FTU) before discharge to the sanitary sewer. The Building 25 FTU treats wastewater in batch mode.

All sampling performed by Berkeley Lab and EBMUD during two monitoring efforts each yielded daily maximum results well within EBMUD discharge limits. ${ }^{1}$ One selfmonitoring measured a level of copper $(2.4 \mathrm{mg} / \mathrm{L})$ slightly above the monthly average limit $(2.07 \mathrm{mg} / \mathrm{L})$, but further sampling measured a much lower level, which brought the monthly average down to a level that was below the compliance threshold.

In 1997, the Photo Fabrication Shop obtained a filter, which first became operable in 1998. This filter was used to remove copper particles from wastewater generated by a 


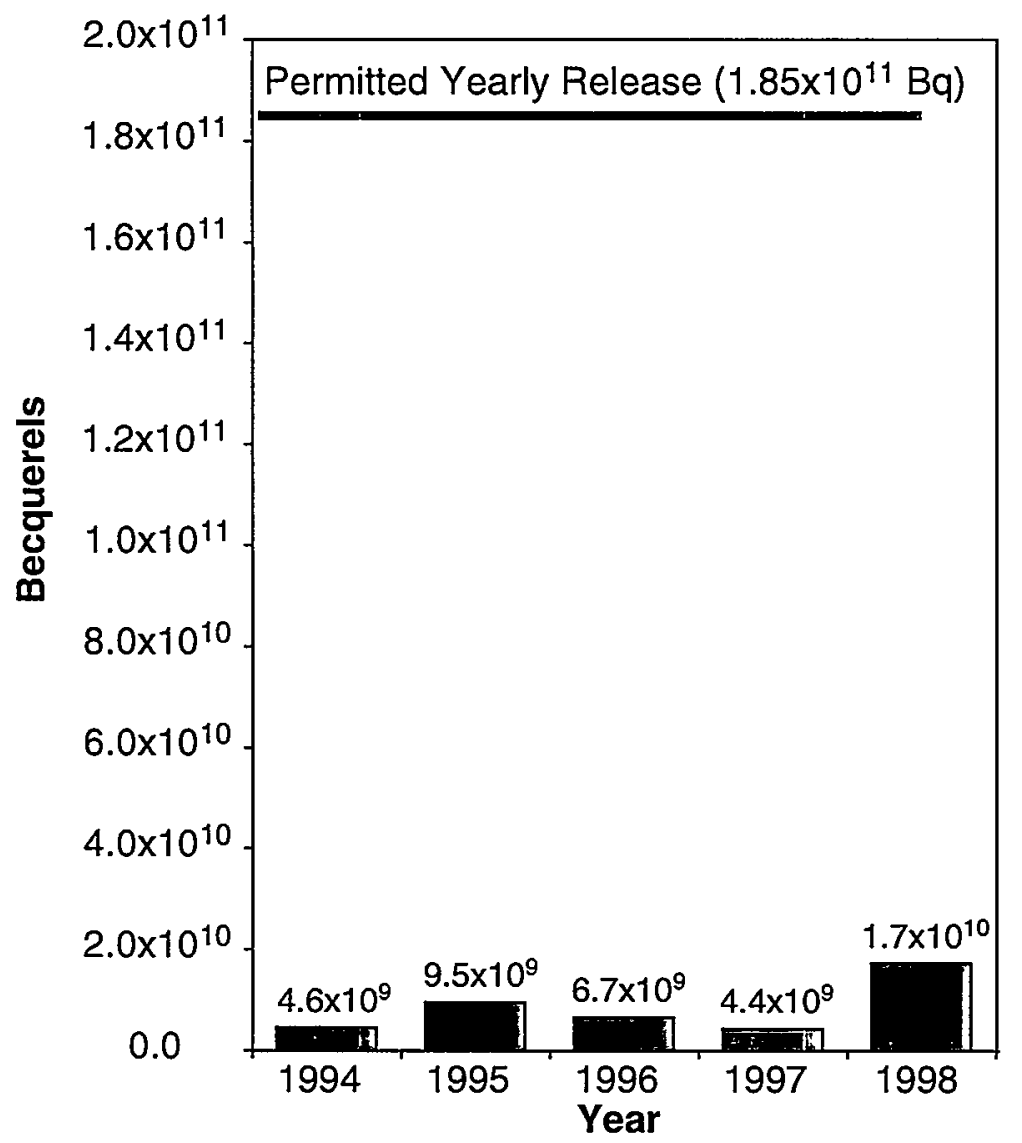

Figure 7-4 Annual Releases of Tritium to Sewers (1994-1998)

mechanical scrubber and a surface deburring machine. This wastewater stream previously was required to be treated through the FTU. Using the filter, the Laboratory can recycle 19,000 liters (5,000 gallons) of water per year and reclaim the copper particles deposited on the filter cloth.

\section{$\$ 7.7 \quad$ C. Building 77 Ultra-High Vacuum Cleaning Facility Wastewater}

The Ultra-High Vacuum Cleaning Facility (UHVCF) at Building 77 cleans various types of metal parts used in research and support operations at Berkeley Lab. Cleaning operations include passivating, acid and alkaline cleaning, and ultrasonic cleaning. Vapor degreasing was phased out during 1998, replaced by a recently installed ultrasonic cleaning system.

Acid and alkaline rinsewaters containing metals from UHVCF operations are routed to a nearby 227-liter (60-gallon) per minute fixed treatment unit, designated FTU 006. During 1998, FTU 001 was officially closed and dismantled. DTSC, the City of Berkeley, and EBMUD were formally notified of the closure.

Three self-monitoring samples were taken from the Building 77 FTU during 1998. For two of them, all parameters analyzed were well within permit limits. ${ }^{1}$ An unplanned 
chromium release to the sewer was detected by the July 9 sampling. This environmental incident was reported to EBMUD and investigated. For details on this incident, see \$3.26.

\section{\$7.8 D. Treated Hydrauger and Extraction Well Discharge}

Since 1993, EBMUD has permitted Berkeley Lab to discharge treated groundwater to the sanitary sewer. The treatment process consists of passing the contaminated groundwater through a double-filtered carbon adsorption system.

The EBMUD permit allows for discharge of treated groundwater from certain hydrauger treatment systems and extraction wells, plus well samplings and developments. All treated groundwater discharged under the permit is routed through the Hearst sewer. One of the conditions for this discharge is a quarterly report on the volumes treated and discharged and any contaminants found.

Tests using US/EPA-approved methodologies are run quarterly on treated groundwater to determine levels of volatile organic compounds. Most results have been "nondetect." Occasional detections of certain chlorinated hydrocarbons have been extremely low (parts per billion) and do not exceed allowable limits. As a precautionary measure, a sample is taken from between the two drums of carbon in each system to assist in determining when the first drum should be changed out. This prevents contaminated groundwater from being discharged to the sanitary sewer. For further discussion of groundwater monitoring and treatment, see chapter 6. 


\section{Soil and Sediment}

\section{BACKGROUND $\$ 8.1$}

II. SOIL AND SEDIMENT SAMPLING $\$ 8.2$

Figure 8-1: Soil and Sediment Sampling Sites $\$ 8.2$

III. SOIL AND SEDIMENT ANALYSIS RESULTS $\$ 8.3$

Table 8-1: Tritium Results in Soil and Sediment Samples $\$ 8.3$

Table 8-2: Metals and Oil/Grease Results in Soil and

Sediment Samples $\$ 8.3$

\section{$\S 8.1 \quad$ I. BACKGROUND}

The analysis of soil and sediment as part of a routine environmental monitoring program can provide information regarding past releases to air or water. DOE guidance recommends - and Berkeley Lab performs-annual soil and sediment sampling to determine long-term accumulation trends and baseline profiles. ${ }^{1}$ No other specific regulatory requirements exist for routinely assessing these media, although any contamination discovered by sampling must be handled according to federal and state hazardous waste regulations. Details on Berkeley Lab's soil and sediment program are included in its Environmental Monitoring Plan. ${ }^{2}$ In 1998, sampling was done in November before the rainy season. All sampling results are presented in volume II.

\section{$\$ 8.2 \quad$ II. SOIL AND SEDIMENT SAMPLING}

In 1998 , soil samples from the top 2 to 5 centimeters ( 1 to 2 inches) of surface soils were collected from three locations around the site and one off-site environmental monitoring station. See Figure 8-1. Locations were chosen to coincide with ambient-air sampling stations. Samples were analyzed for gross alpha and gross beta radiation, gamma emitters, tritium, metals, moisture content, and pH. In 1998, soil samples were not analyzed for semivolatiles (as was done previously), because historical results demonstrated that these analytes in soils were consistently below practical quantification limits.

Sediment samples were collected during the same period from main and tributary creek beds of the North Fork of Strawberry Creek and Chicken Creek. See Figure 8-1. Sediment samples were analyzed for gross alpha and gross beta radiation, gamma 


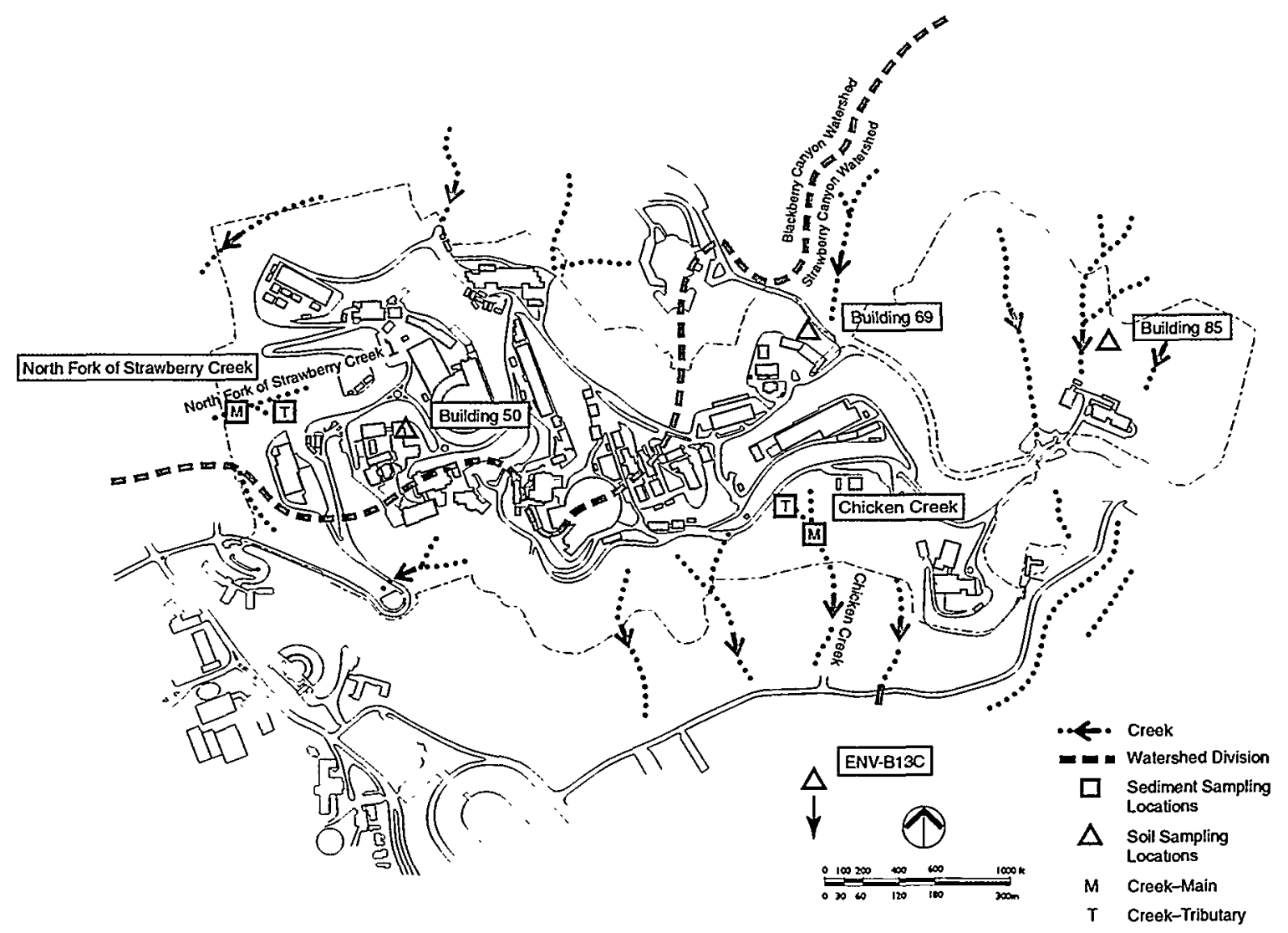

Figure 8-1 Soil and Sediment Sampling Sites

emitters, tritium, metals, polychlorinated biphenyls (PCBs), petroleum hydrocarbons (diesel fuel and oil and grease), and $\mathrm{pH}$.

\section{§8.3 III. SOIL AND SEDIMENT ANALYSIS RESULTS}

All gross alpha, gross beta, and gamma-emitter results were similar to background levels of naturally occurring radioisotopes commonly found in soil and sediment. Tritium levels measured were comparable to results reported for these locations in previous years. In 1998, only three of the eight samples contained detectable levels of tritium. The maximum tritium level in soil was 0.059 becquerels per gram of soil near Building 69 . The maximum tritium level in sediment was $0.042 \mathrm{~Bq} / \mathrm{g}$ at the Chicken Creek-Main location. Table 8-1 summarizes the soil and sediment analysis results for tritium.

Berkeley Lab is currently conducting a corrective action program under the Resource Conservation and Recovery Act of 1976 (RCRA) to investigate soil and groundwater tritium contamination near the National Tritium Labeling Facility. For a summary of the RCRA investigation, see $\$ 3.18$. For groundwater monitoring results, see $\S 6.11$.

All results for metals analyses were also within normal levels for soil and sediment and well below regulatory levels. ${ }^{3}$ PCB results for sediment samples were near or below practical quantification limits. Measurements for $\mathrm{pH}$ were within the normal range for soils and sediments. The maximum level of oil and grease $(960 \mathrm{mg} / \mathrm{kg}$ ) was measured at 


\begin{tabular}{|c|c|c|}
\hline Sampling location & Matrix & Tritium $(B q / g)^{b}$ \\
\hline Building 50 & Soil & $<0.003^{\mathrm{c}}$ \\
\hline Building 69 & Soil & 0.0589 \\
\hline Building 85 & Soil & $<0.003^{c}$ \\
\hline ENV-B13C & Soil & $<0.003^{\mathrm{c}}$ \\
\hline Chicken Creek-Main & Sediment & 0.0419 \\
\hline Chicken Creek-Tributary & Sediment & 0.0142 \\
\hline North Fork Strawberry Creek-Main & Sediment & $<0.003^{c}$ \\
\hline North Fork Strawberry Creek-Tributary & Sediment & $<0.003^{c}$ \\
\hline
\end{tabular}

a One sample per location

$b_{1} \mathrm{~Bq}=27 \mathrm{pCi}$

${ }^{c}$ Result below detection limit

the Chicken Creek-Tributary location. Oil and grease contamination is commonly associated with motorized vehicles on roads and parking lots. The Laboratory's Cyclotron Road traverses the grade directly above the sampling site. This location will be sampled in future years to monitor any changes.

Table 8-2 shows metals (where at least one sample was above the limit of quantification) and oil and grease results. 
Sample Location

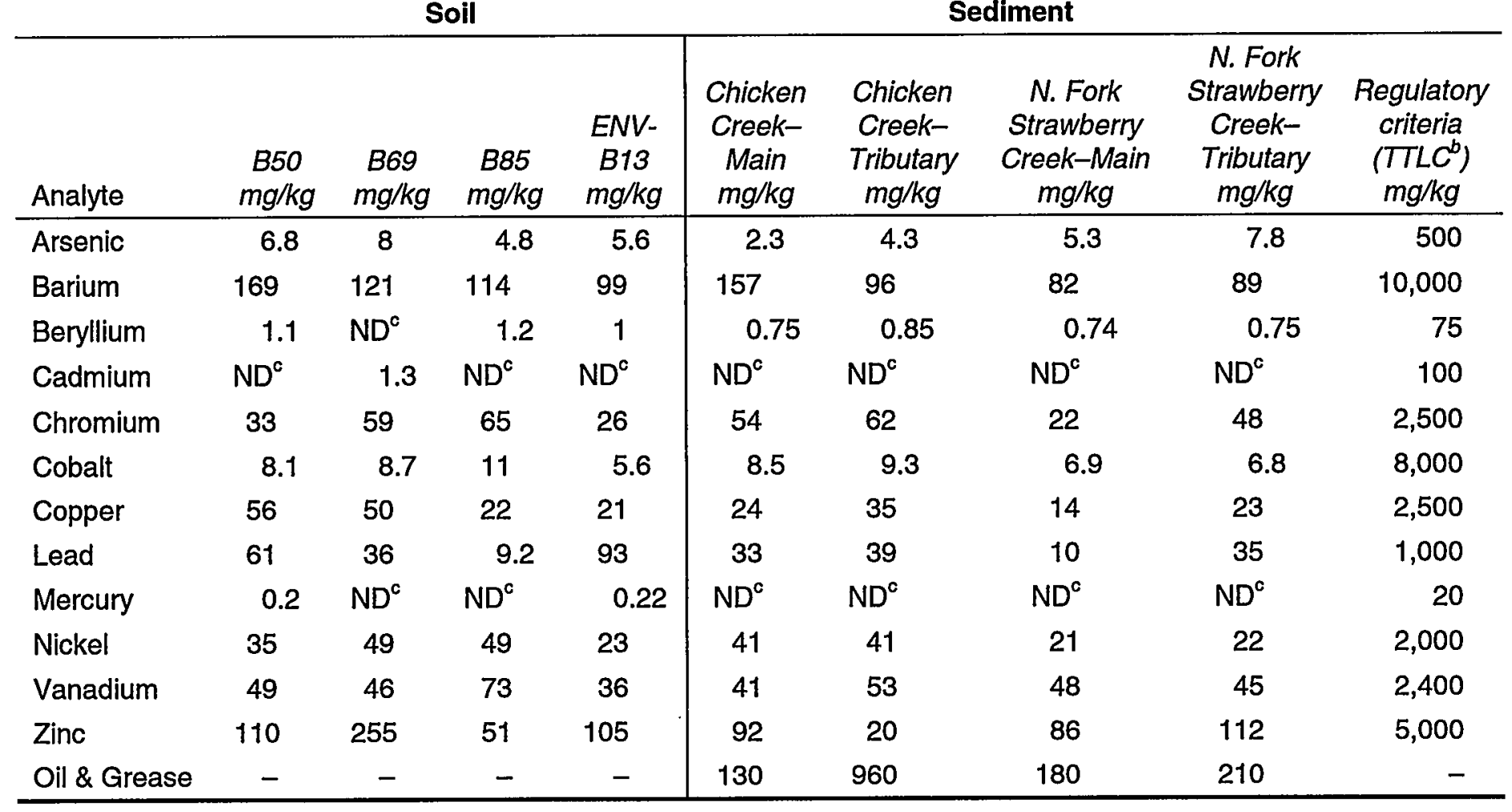

One sample per location

b Total Threshold Limit Concentration (22 California Code of Regulations 66261.24) ${ }^{3}$

c Result was below detection limit.

d Results for antimony, molybdenum, selenium, silver, and thallium were all below practical quantification limits and are not reported in Table 8-2.

These results, along with other non-TTLC metals (aluminum, boron, manganese, and iron), are included in volume II. 


\section{9 \\ Vegetation and Foodstuffs}

I. BACKGROUND $\$ 9.1$

II. TREE SAMPLING $\$ 9.2$

Figure 9-1: Tree-Stand Areas 1-7

Figure 9-2: Sample Locations in Area 1

Figure 9-3: Sample Locations in Areas 2-7

III. RESULTS $\$ 9.3$

Figure 9-4: Free-Water Tritium in Tree Wood with Distance from NTLF Main Stack (Area 1)

Figure 9-5: Organically Bound Tritium in Tree Wood with Distance from NTLF Main Stack (Area 1)

Figure 9-6: Free-Water Tritium in Leaf and Duff with Distance from NTLF Main Stack (Area 1)

Figure 9-7: Organically Bound Tritium in Leaf and Duff with Distance from NTLF Main Stack (Area 1)

Figure 9-8: Free Water in Tree Wood, Leaf, and Duff from Areas 2-7

Figure 9-9: Organically Bound Tritium in Tree Wood, Leaf, and Duff from Areas 2-7

IV. SUMMARY $\$ 9.4$

\section{$\$ 9.1 \quad$ I. BACKGROUND}

Sampling of vegetation and foodstuffs can provide information regarding the presence, transport, and distribution of radioactive emissions in the environment. This information can be used to detect and evaluate changes in environmental radioactivity resulting from Berkeley Lab activities and to calculate potential human doses from consuming vegetation and foodstuffs. Possible pathways or routes for ingesting radionuclides include:

- Liquid effluent $\rightarrow$ marine species $\rightarrow$ human;

- Airborne emissions $\rightarrow$ vegetable crop $\rightarrow$ human;

- Airborne emissions $\rightarrow$ forage crop $\rightarrow$ meat (milk) animal $\rightarrow$ human; 
- Airborne emissions $\rightarrow$ exchange to surface water body $\rightarrow$ aquatic species $\rightarrow$ human; and

- Airborne emissions $\rightarrow$ surface or groundwater $\rightarrow$ vegetable crop $\rightarrow$ human.

Department of Energy (DOE) guidance indicates that when the annual effective dose equivalent for the consumption of vegetation and foodstuffs is between $0.001 \mathrm{mSv}$ $(0.1 \mathrm{mrem})$ and $0.01 \mathrm{mSv}(1 \mathrm{mrem})$, only a minimal vegetation and foodstuff surveillance program is required. ${ }^{1}$ Using conservative assumptions, Berkeley Lab's maximum individual dose attributable to the consumption of locally grown vegetation and foodstuffs was well below the requirement for a minimal monitoring program. Tritium air emissions were identified as the only potentially significant contributor to these pathways.

Tritium emissions can be in the form of tritiated water vapor or tritiated hydrogen gas. The relative dose from an exposure to tritiated hydrogen gas is much less than that from an equal exposure to tritiated water. Nevertheless, in modeling and dose calculations, the Laboratory conservatively assumes that $100 \%$ of the emissions are tritiated water vapor to provide a safe over-estimate of actual dose.

Tritiated water vapor released to the environment mixes and exchanges readily with atmospheric water (e.g., precipitation, fog, vapor) and with other sources of environmental water (e.g., plant water, surface water, soil water). Within plants, tritium exists as either free-water tritium or organically bound tritium.

The Laboratory's Environmental Monitoring Plan ${ }^{2}$ outlines the current vegetation sampling program. The objective of this portion of the program is to better understand the distribution of tritium in local vegetation.

\section{$\$ 9.2$ II. TREE SAMPLING}

Berkeley Lab manages on-site trees and vegetation (and some immediately adjacent to the University of California) as part of a multi-year wildland fire task management program and its maintenance program for a fire-safe landscape. ${ }^{3}$ In the future, Berkeley $\mathrm{Lab}$ is considering thinning nonnative tree stands around Buildings 75,76 , and 77 . See Figure 9-1.

Environmental tritium levels have been determined to be above regional background levels near the National Tritium Labeling Facility and decrease with distance from the facility stack. ${ }^{4}$ A sampling and analysis plan was developed and implemented in 1998 to characterize tritium concentrations within tree stands that might be thinned in the future. ${ }^{5}$ See Figure 9-1. Tree selection and sampling was designed to (a) provide representative samples for characterizing tritium levels within the tree stands, (b) prevent sample cross contamination, and (c) estimate field sampling variability.

Samples of wood core and chip, leaf, and duff were collected from seven tree stands and a remote location at Chabot Regional Park (approximately 20 kilometers south of Berkeley Lab). Duff consists of tree litter and other decomposing vegetation material that lies on the ground under a tree canopy. Eucalyptus and pine trees were sampled using a systematic and documented procedure. The samples were analyzed at a commercial laboratory for free-water tritium (FWT) and organically bound tritium (OBT). 


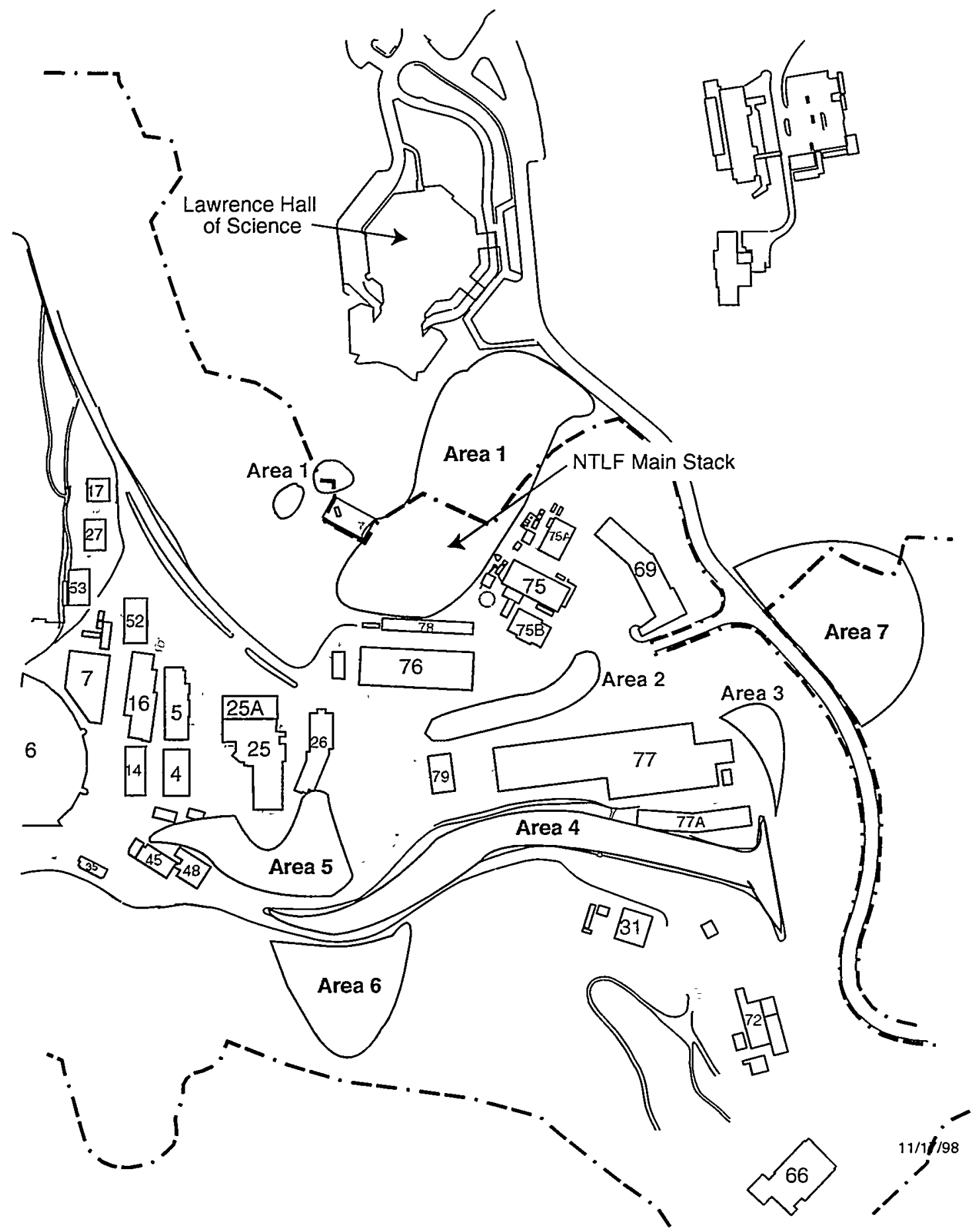

Figure 9-1 Tree Stand Areas 1-7 
To characterize tritium levels in the tree stand around the National Tritium Labeling Facility's (NTLF) main stack (Area 1), a radial sampling pattern was selected to more easily identify tritium concentration changes and contours. See Figure 9-2. All other tree stands were sampled using an areal grid pattern that divided each stand into cells of approximately equal area. See Figure 9-3.

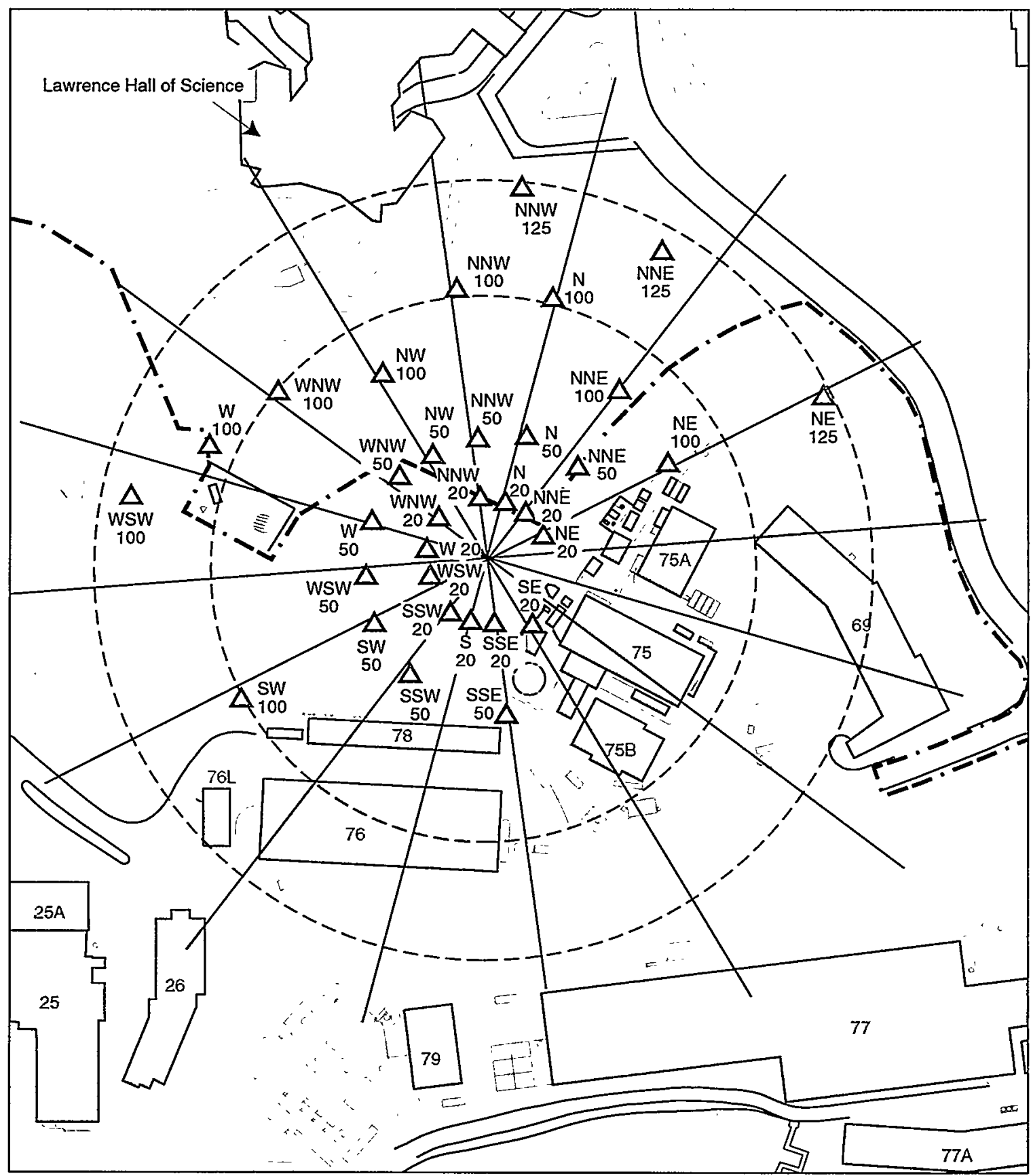

Figure 9-2 Sample Locations in Area 1 


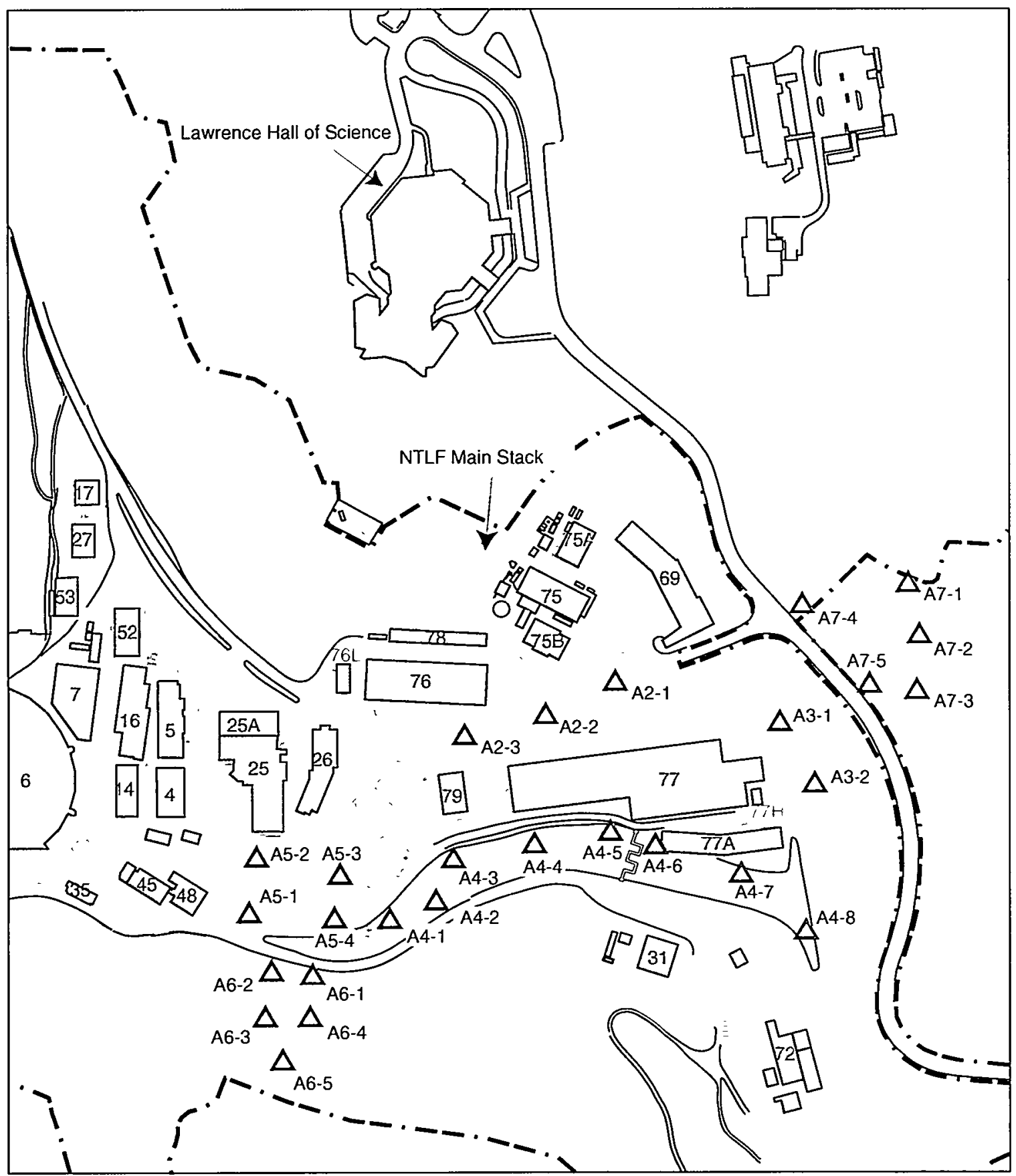

Figure 9-3 Sample Locations in Areas 2-7

\section{$\$ 9.3 \quad$ III. RESULTS}

The tritium results from the vegetation samples are summarized in Figures 9-4, 9-5, 9-6, 9-7, 9-8, and 9-9. A detailed listing of all tritium results is included in volume II. Tritium results for wood, leaf, and duff from a remote sampling location at Chabot Regional Park were all below or near the analytical detection limits. Nominal minimum detectable activities were $0.007 \mathrm{~Bq} / \mathrm{g}$ for FWT and $0.07 \mathrm{~Bq} / \mathrm{g}$ for OBT. 


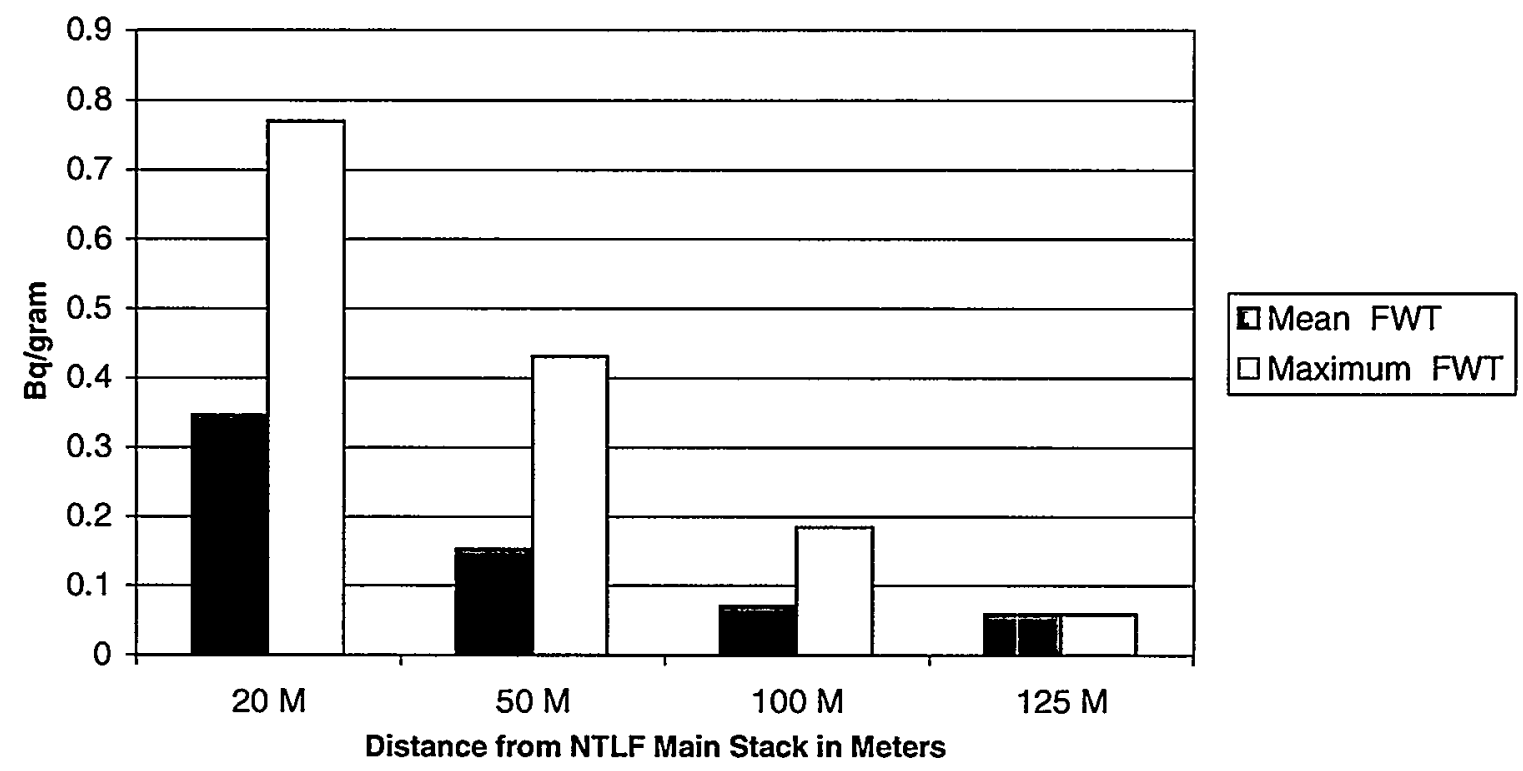

Figure 9-4 Free-Water Tritium in Tree Wood with Distance from NTLF Main Stack (Area 1)

Within Area 1, the mean and maximum FWT levels measured in tree wood (33 samples) were $0.19 \mathrm{~Bq} / \mathrm{g}$ and $0.77 \mathrm{~Bq} / \mathrm{g}$, respectively. The mean and maximum OBT levels measured in tree wood (32 samples) from Area 1 were $<0.07 \mathrm{~Bq} / \mathrm{g}$ and $0.32 \mathrm{~Bq} / \mathrm{g}$, respectively.

Figures 9-4 and 9-5 provide summary data on Area 1 FWT and OBT results for tree wood at specific distances from the NTLF main stack. As the figures show, both FWT and OBT levels in tree wood generally decrease with distance from the stack in Area 1.

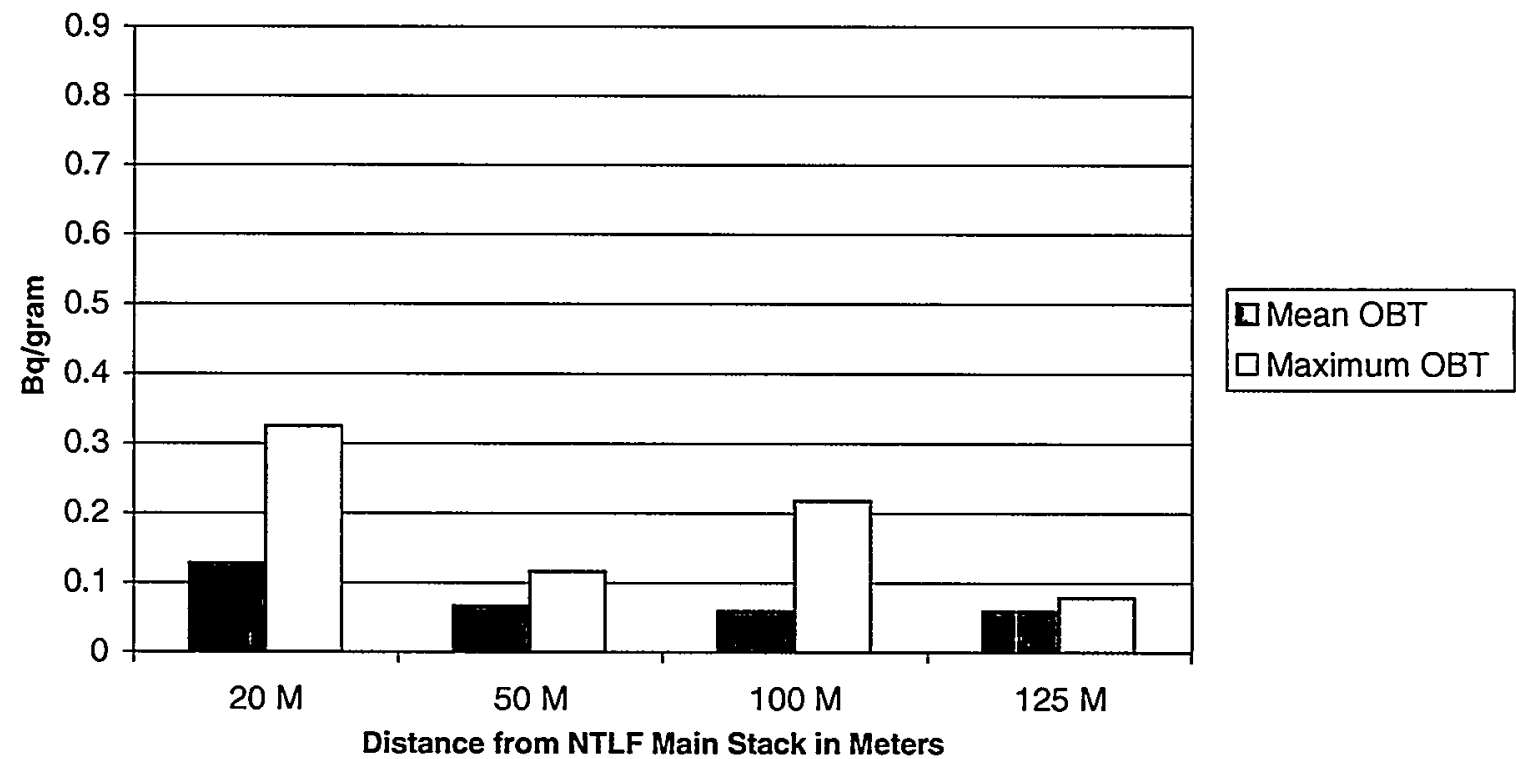

Figure 9-5 Organically Bound Tritium in Tree Wood with Distance from NTLF Main Stack (Area 1) 


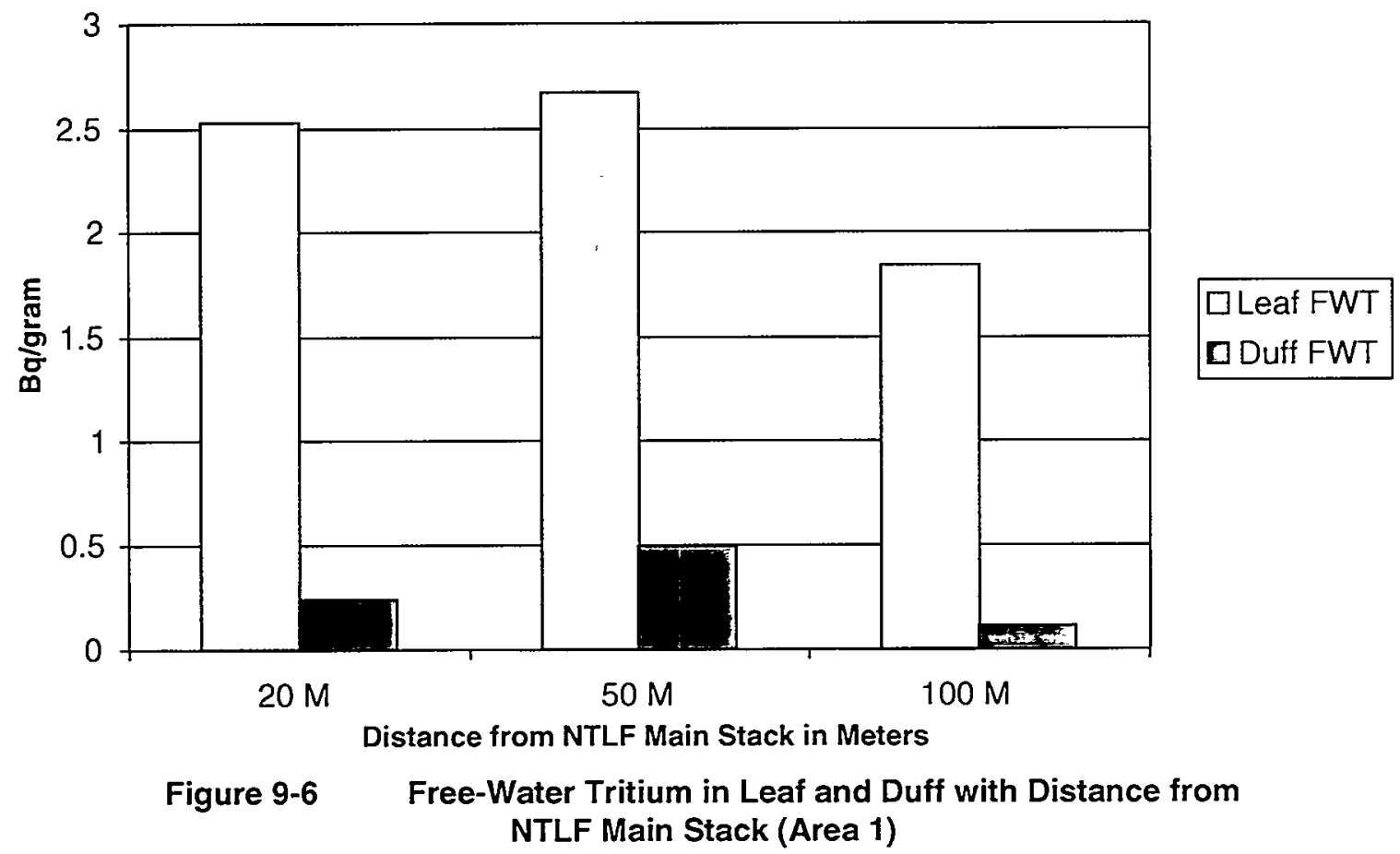

FWT levels in tree wood, however, decrease more rapidly and more consistently than OBT levels in tree wood with distance.

Area 1 FWT and OBT levels measured in leaf samples and duff samples are shown in Figures 9-6 and 9-7. Only three samples of leaf and duff were collected from Area 1

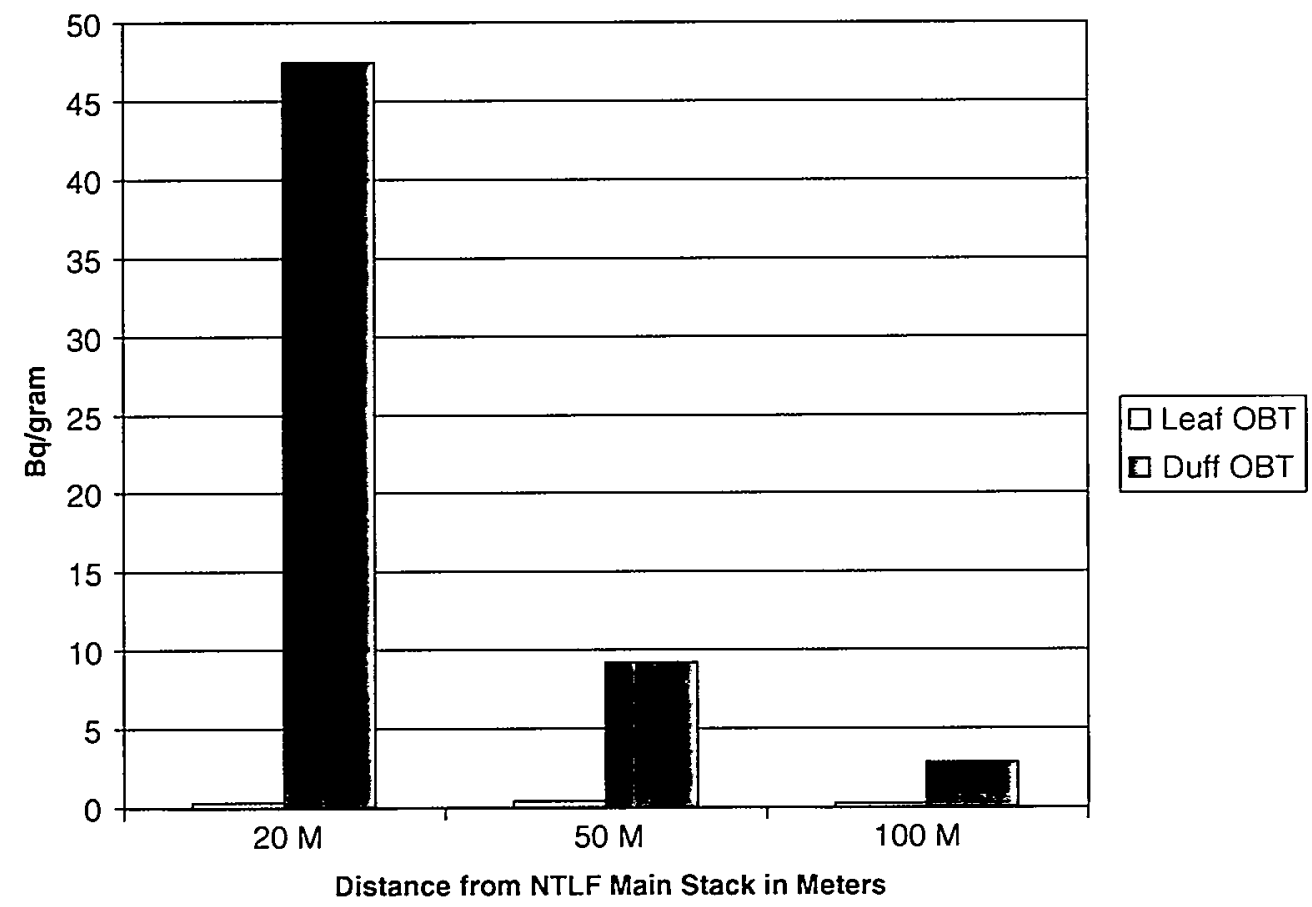

Figure 9-7 Organically Bound Titium in Leaf and Duff with Distance from NTLF Main Stack (Area 1) 


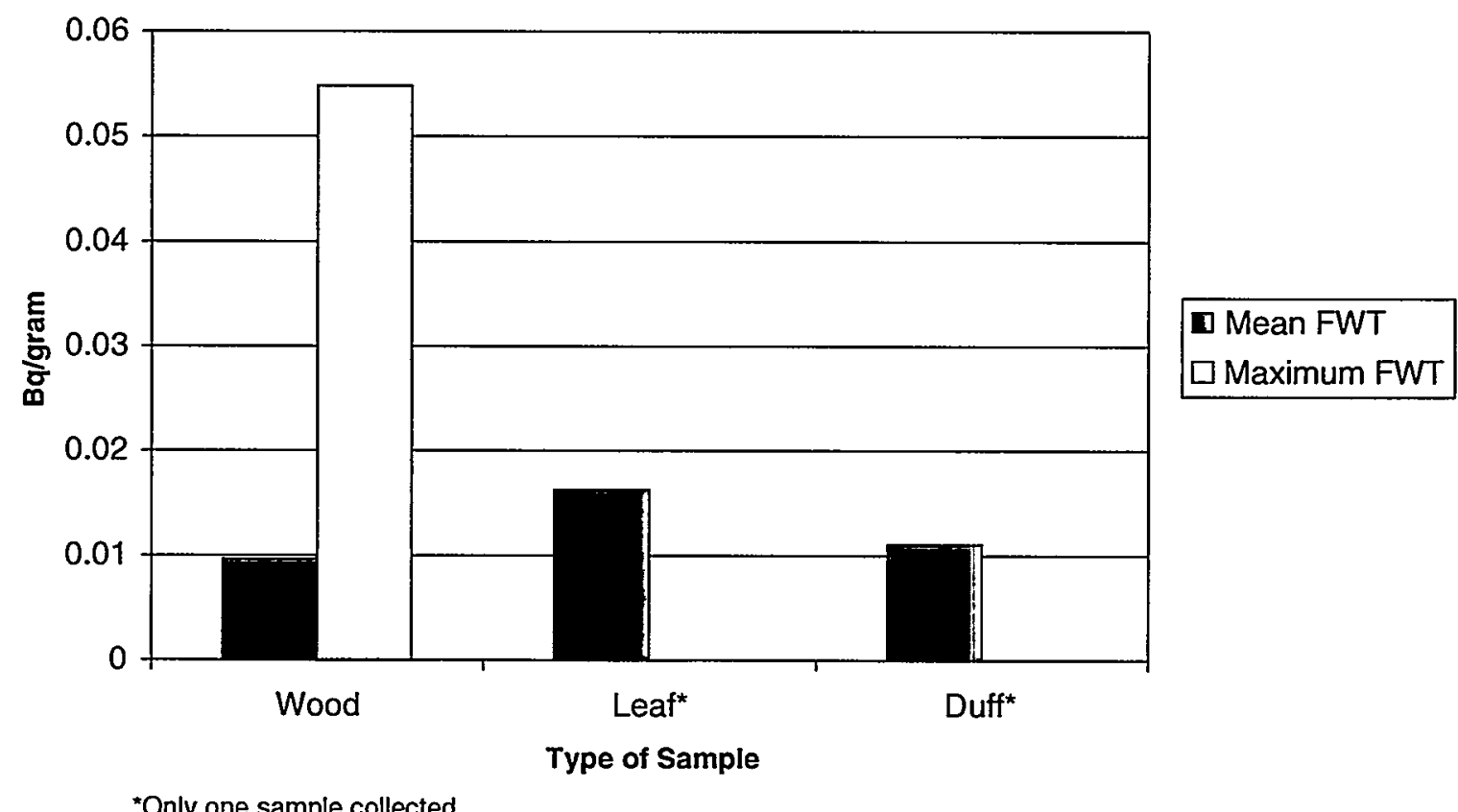

*Only one sample collected.

Figure 9-8 Free Water in Tree Wood, Leaf, and Duff from Areas 2-7

along a north-northwest transect from the NTLF main stack. Duff samples collected from Area 1 contained the highest OBT levels measured: $47 \mathrm{~Bq} / \mathrm{g}$ (see Figure 9-7). OBT levels in the duff samples rapidly decrease with distance from the NTLF main stack. OBT levels measured in leaves from Area 1 were substantially lower than those in duff from the same locations.

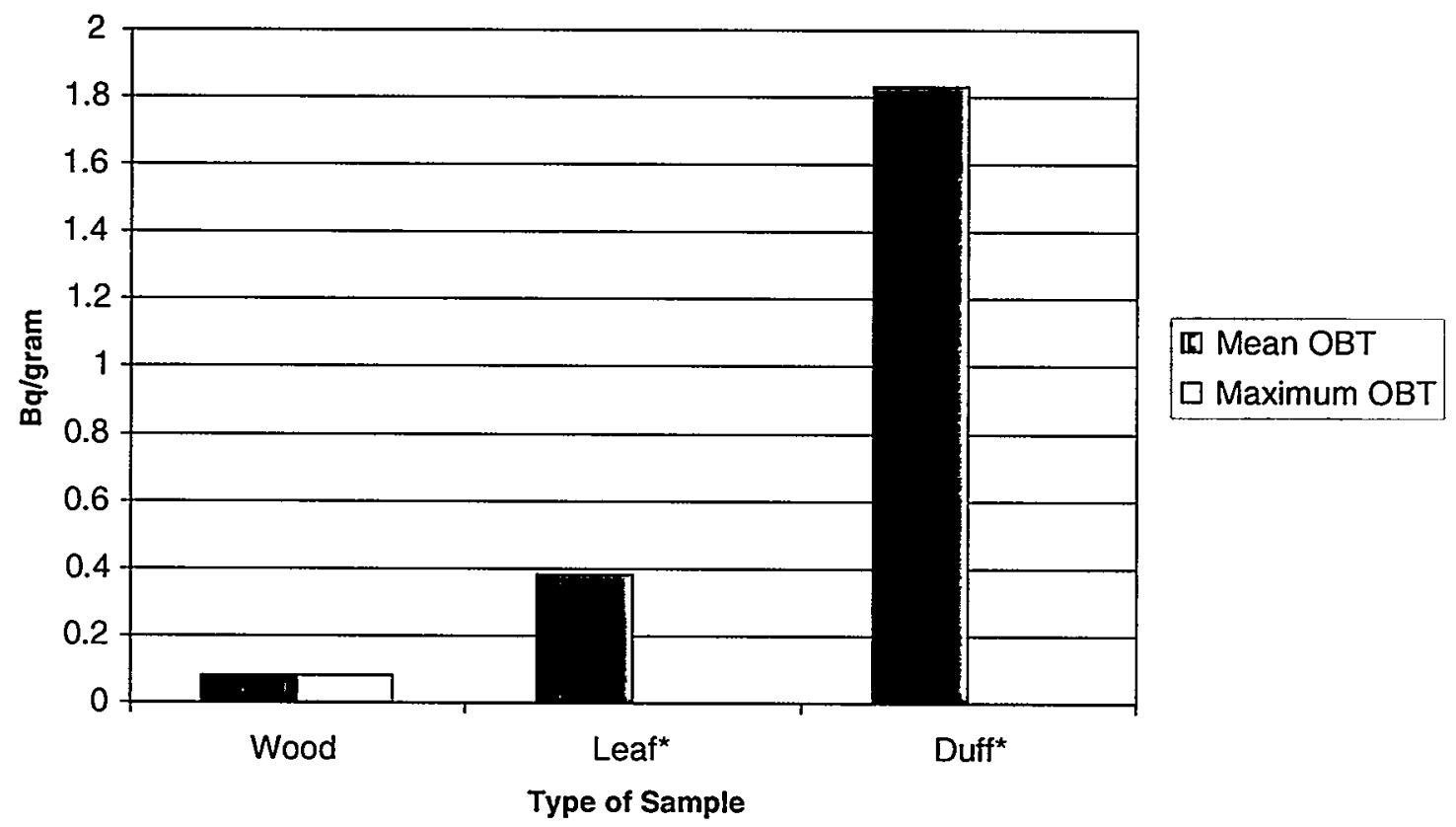

*Only one sample collected.

Figure 9-9 Organically Bound Tritium in Tree Wood, Leaf, and Duff from Areas 2-7 
FWT and OBT results for tree wood, lead, and duff samples from Areas 2-7 (see Figures 9-8 and 9-9) were significantly lower than the same sample types in Area 1. The mean and maximum FWT for tree wood (27 samples) in Areas 2-7 was $0.0096 \mathrm{~Bq} / \mathrm{g}$ and $0.055 \mathrm{~Bq} / \mathrm{g}$, respectively. The mean and maximum OBT in tree wood (27 samples) for Areas 2-7 were both below the analytical detection limit.

\section{$\$ 9.4$ IV. SUMMARY}

The results from the sampling and analysis conducted in 1998 confirm what has been previously measured and reported: tritium concentrations in vegetation are slightly elevated above regional background levels near the NTLF main stack and decrease with distance from the stack. At about 200 meters from the NTLF stack, FWT and OBT levels in vegetation are nearly indistinguishable from regional background levels. Additional sampling and analysis of tree wood, leaf, and duff in Area 1 and from other on-site areas will be performed in 1999 to supplement the information that has been gathered to date. This tritium characterization data gathered will be utilized in preparing an application for the authorization of release limits for tritium in vegetation, which will be submitted to the Department of Energy.

Routine sampling of vegetation and foodstuffs is not required under any applicable environmental regulations. Berkeley Lab undertakes voluntary sampling efforts to better understand the integrated impact of its operations on all media in the surrounding environment and to verify its overall dose-assessment program. This assessment program, which is presented in chapter 10 , includes vegetation and foodstuffs as one of the contributing pathways in determining the overall impact from Berkeley Lab's airborne radionuclides. Dose assessments performed using very conservative assumptions indicate extremely small potential impacts. 


\section{Radiological Dose Assessment}

I. BACKGROUND \$10.1

II. PENETRATING RADIATION MONITORING RESULTS $\$ \mathbf{\$ 1 0 . 2}$
A. Accelerator-Produced Penetrating Radiation \$10.3

Figure 10-1: Environmental Penetrating Radiation Monitoring Stations

Table 10-1: Annual Penetrating Radiation Dose at Site Perimeter Resulting from Accelerators

Table 10-2: Summary of Environmental TLD Monitoring Results

B. Irradiator-Produced Penetrating Radiation $\$ \mathbf{\$ 1 0 . 4}$

III. DISPERSIBLE AIRBORNE RADIONUCLIDE RESULTS \$10.5

Table 10-3: Summary of Dose Assessment at Location of Maximally Exposed Individual (MEI)

\section{COMBINED DOSE ASSESSMENT \$10.6}

Table 10-4: Summary of Radiological Dose Impacts

Figure 10-2: Comparison of Radiological Dose Impact

\section{$\$ 10.1$ I. BACKGROUND}

This chapter presents the estimated dose results from Berkeley Lab's penetrating radiation and airborne radionuclide monitoring programs. The doses projected from each monitoring program are given separately, before being evaluated cumulatively at the end of the chapter to summarize the overall impact of the Laboratory's radiological activities on the surrounding region.

Earlier chapters referred to monitoring and sampling results in terms of concentrations of a substance. The health effect of exposure to a concentration over a period of time is referred to as "dose." An important measure for evaluating the impact of any radiological program, dose can be estimated for individuals as well as populations. Factors affecting either type of dose (individual or population) include the distance from the activity, complexity of terrain, meteorological conditions, emission levels, food production and consumption patterns, and length of exposure. 


\section{$\$ 10.2$ II. PENETRATING RADIATION MONITORING RESULTS}

Radiation-producing machines (e.g., accelerators, $\mathrm{x}$-ray machines, irradiators) and various radionuclides are used at Berkeley Lab for high-energy particle studies and biomedical research. Penetrating radiation is mainly associated with accelerator and irradiator operations at the Laboratory. Accelerators produce both gamma and neutron forms of radiation. Irradiators are primarily limited to gamma radiation.

Historically, Department of Energy (DOE) facilities have reported "fence-post doses." These are measured or computed values reflecting the exposures to an individual assumed to be living $100 \%$ of the time at the perimeter or fence-line of the facility. In order to present realistic assessments of exposures to actual individuals (not overly conservative and unrealistic estimates), this chapter provides both maximum fence-post dose estimates and more realistic estimates of exposures to workplaces or residences of Berkeley Lab's nearest neighbors.

\section{$\$ 10.3$ A. Accelerator-Produced Penetrating Radiation}

Berkeley Lab operates detection equipment at environmental monitoring stations near the site's research accelerators that generate penetrating radiation when operational. These accelerators are the Advanced Light Source (Building 6), Biomedical Isotope Facility (Building 56), and 88-Inch Cyclotron (Building 88).

Berkeley Lab uses two methods to determine the environmental radiological impact from accelerator operations. One method utilizes a network of three real-time environmental monitoring stations located around the site's perimeter to track the instantaneous gamma and neutron radiation impacts from accelerator operations. Figure 10-1 shows the location of these stations. Each real-time station contains sensitive gamma and neutron pulse counters, which continuously detect and record direct gamma and neutron radiation-both of which are forms of penetrating radiation. The gamma and neutron doses to an individual are derived from measurements at the three monitoring stations and result from accelerator operations for the year. These doses are listed in Table 10-1.

The second method uses 27 passive detectors known as thermoluminescent detectors (TLDs) located near the site boundary and six additional TLDs located around two offsite facilities (Building 903 Warehouse and Building 934). TLDs measure only gamma radiation because they do not have sufficient sensitivity to detect environmental levels of neutron radiation. TLDs are not able to exclude background radiation from their results and give time-average dose results that must be determined by an analytical technique rather than real-time instrumentation. Figure 10-1 shows the locations of TLD sites near the main facility.

The objectives of the TLD measurement are to record the gross penetrating radiation exposures (from background and from LBNL operations) and to ensure that public radiation exposure is kept well below allowable regulatory limits. TLDs use aluminum oxide, which can measure low-level gamma and photon radiation with a minimum detection level of $0.001 \mathrm{mSv}(0.1 \mathrm{mrem})$. Table 10-2 summarizes the calculated annual average TLD gamma radiation dose equivalents from the environmental TLD monitoring program, organizing the 33 monitoring locations into similar groups. 


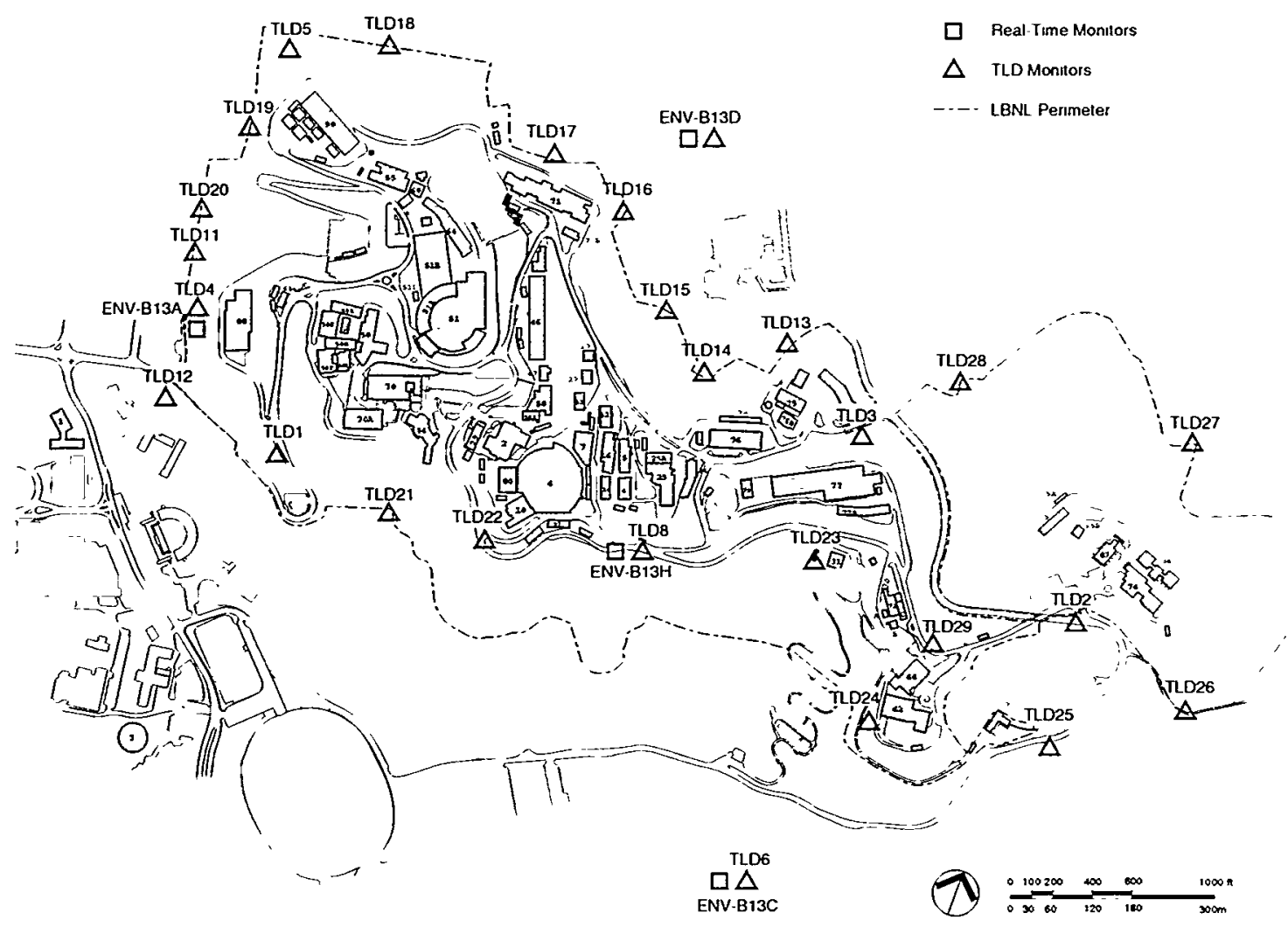

Figure 10-1 Environmental Penetrating Radiation Monitoring Stations

Annual TLD radiation dose measurements at each individual monitoring locations are similar and near the typical background dose for natural gamma radiation in California: $0.72 \mathrm{mSv}$ (72 mrem). These TLD results confirm the low dose values measured by the real-time monitoring stations. See Table 10-1.

Another measure of the potential impact of accelerator-produced penetrating radiation is the population dose equivalent. For many years, Berkeley Lab has used a sitespecific model to estimate the population dose equivalent resulting from penetrating radiation. ${ }^{2}$ Population data from the 1980 United States Census ${ }^{3}$ are used in this calculation. Although the population within 80 kilometers (50 miles) of Berkeley Lab

Table 10-1 Annual Penetrating Radiation Dose at Site Perimeter Resulting from Accelerators

\begin{tabular}{lccc}
\hline \multicolumn{1}{c}{ Monitoring station } & $\begin{array}{c}\text { Net gamma dose } \\
(\mathbf{m S v} / \mathrm{yr})^{\mathrm{a}}\end{array}$ & $\begin{array}{c}\text { Net neutron dose } \\
(\mathrm{mSv} / \mathrm{yr})\end{array}$ & $\begin{array}{c}\text { Total dose }^{\mathrm{b}} \\
(\mathrm{mSv} / \mathrm{yr})\end{array}$ \\
\hline ENV-B13A (Bldg. 88) & 0.001 & 0.003 & 0.004 \\
ENV-B13C (Panoramic) & $<0.001$ & $<0.001$ & $<0.002$ \\
ENV-B13H (ALS) & $<0.001$ & $<0.001$ & $<0.002$ \\
\hline
\end{tabular}

$\mathrm{a}_{1} \mathrm{mSv}=100 \mathrm{mrem}$

b Standard of comparison is DOE limit of $1 \mathrm{mSv} /$ year. 
Table 10-2 Summary of Environmental TLD Monitoring Results ${ }^{a}$

\begin{tabular}{lcc}
\hline \multicolumn{1}{c}{ Location } & $\begin{array}{c}\text { Number } \\
\text { of sites }\end{array}$ & $\begin{array}{c}\text { Average annual dose } \\
(\mathrm{mSv})^{\mathrm{b}}\end{array}$ \\
\hline Laboratory gate entrances & 3 & 0.59 \\
Environmental monitoring stations & 5 & 0.66 \\
Laboratory perimeter & 19 & 0.58 \\
Off-site facilities & 6 & 0.55 \\
\hline \multicolumn{1}{c}{ Average dose } & 33 & 0.59 \\
\hline a Results include background dose. Average background in Bay Area is typically $0.72 \mathrm{mSv}$. \\
Background dose rate can vary between locations and years. \\
b 1 mSv $=100$ mrem
\end{tabular}

increased by about 20\% during the 1970s and 1980s from 5 to 6 million, the populations of Berkeley and Oakland (the two cities immediately adjacent to the site) declined. Population statistics from the 1990 census have not produced noticeable differences in dose.

In the Laboratory's model, population dose equivalent is computed from the maximum measured value of perimeter dose. For 1998, this maximum dose was collected at monitoring station ENV-B13A. See Table 10-1. The collective effective dose equivalent to the approximately 5-million people within 80 kilometers (50 miles) of Berkeley Lab attributable to penetrating radiation from Laboratory accelerator operation during 1998 was estimated at $4.34 \times 10^{-4}$ person-Sv $\left(4.34 \times 10^{-2}\right.$ person-rem).

\section{$\$ 10.4$ B. Irradiator-Produced Penetrating Radiation}

Used for radiobiological and radiochemical research, Berkeley Lab has a single gamma irradiator, with a 1400 curie cobalt-60 source. This unit is housed in a massive interlocked, reinforced-concrete-covered structure built as part of Building 74. Routine surveys taken when the irradiator was in operation confirmed that no area exceeded 0.01 $\mathrm{mSv} / \mathrm{hr}(1 \mathrm{mrem} / \mathrm{hr})$ at $1 \mathrm{~meter}$ from the outside walls or ceiling of the labyrinth. The Building 74 irradiator is about 80 meters ( 260 feet) from the site's perimeter fence and more than 700 meters (2,300 feet) from the nearest residence.

The projected annual dose equivalent to any member of the public is less than $0.01 \mathrm{mSv} / \mathrm{yr}(1.0 \mathrm{mrem} / \mathrm{yr})$ at the perimeter fence and less than $2 \times 10^{-4} \mathrm{mSv} / \mathrm{yr}$ $(0.02 \mathrm{mrem} / \mathrm{yr})$ at the nearest residence. The remaining smaller, well-shielded gamma irradiators pose considerably less environmental impact than the Building 74 irradiator and do not increase the cumulative dose level. Because the locations of the maximum doses are different for each radiological-producing activity, the type of maximum cumulative dose is not additive. See $§ 10.6$.

\section{$\$ 10.5$ III. DISPERSIBLE AIRBORNE RADIONUCLIDE RESULTS}

Dose due to dispersible contaminants represents the time-weighted exposure to a concentration of a substance, whether the concentration is inhaled in air, ingested in drink or food, or absorbed through skin contact with soil or other environmental media. 
Dispersible radionuclides that affect the environmental surroundings of Berkeley Lab, and consequently the projected dose from Laboratory activities, originate as emissions from building exhaust points - generally located on rooftops. Once emitted, these radionuclides may affect any of several environmental media: air, water, soil, plants, and animals. Each of these pathways represents a possible pathway of exposure affecting human dose. Determining the dose to an individual and the population is accomplished using multipathway dispersion models. The basic radionuclide inputs for this modeling are the airborne emissions presented in chapter 4.

The US/EPA National Emission Standards for Hazardous Air Pollutants (NESHAPs) regulation requires that any facility that releases airborne radionuclides, like Berkeley Lab, must compute the impact of such releases using an approved computer program. ${ }^{4}$ Berkeley Lab uses CAP88-PC for this purpose.

CAP88-PC is a radionuclide dispersion and dose-assessment predictive model supplied and approved by US/EPA. It computes the cumulative dose from all significant exposure pathways such as inhalation, ingestion, and skin absorption. The methods and parameters used to calculate the dose are quite conservative, taking an approach that reports dose calculations as "worst case" doses to the population exposed. For example, the model assumes that some portion of the food consumed by the individual was grown within the assessed area, that the individual resided at this location continuously throughout the year, and that all the radioactivity released was the most hazardous form. Consequently, this worst-case dose is not a dose likely to be received by anyone, but merely an upper-bound estimate.

In addition to the emissions information, dose-assessment modeling requires the meteorological parameters of wind speed, wind direction, and atmospheric stability. Before 1995, Berkeley Lab's dose-assessment modeling efforts used Oakland airport data that US/EPA distributed with the model. Berkeley Lab started using on-site data with the 1995 NESHAPs assessment after it completed a project to upgrade its local meteorological network.

Berkeley Lab set up 15 individual CAP88-PC modeling runs to predict the impact from groupings of the Laboratory's release points. Table 10-3 lists the attributes of these groupings. Details on these groupings and modeling runs are included in the Laboratory's annual report under the NESHAPs program. The location of the maximally exposed individual was determined from the complete set of modeling runs. The source groupings listed in Table 10-3 give the orientation of their release points relative to the location of the maximally exposed individual (distance and direction). The combined dose from airborne radionuclides for 1998 was less than $0.003 \mathrm{mSv}(0.3 \mathrm{mrem})$.

Collective population dose is calculated as the average radiation dose in a specified region, multiplied by the number of individuals in that area. The region is defined by regulation as a circular area around the site with a radius of 80 kilometers (50 miles). Berkeley Lab divided this region into 208 sectors (i.e., 13 increasingly smaller circles, each divided into 16 equally spaced sectors) and again used CAP88-PC to estimate the average dose to each sector. Input parameters for the model used those from the Building 75 dose assessment, with the exception that the source term was expanded from tritium to include all the radionuclides used at the Laboratory. Population data for each area from the 1980 census were then used to estimate the population dose within each area. The total collective population dose represents the summation of the population doses from all 
Table 10-3 Summary of Dose Assessment at Location of Maximally Exposed Individual (MEI)

\begin{tabular}{|c|c|c|c|c|c|}
\hline Building & Building description & $\begin{array}{c}\text { Distance } \\
\text { to ME|a } \\
\text { (meters) }\end{array}$ & $\begin{array}{c}\text { Direction } \\
\text { to } \mathrm{MEI}^{\mathrm{a}}\end{array}$ & $\begin{array}{c}\text { Dose at } \\
\text { MEI } \\
\text { (mSv/yr) }^{b}\end{array}$ & $\begin{array}{c}\text { Percent of } \\
\text { MEl dose }\end{array}$ \\
\hline 75 & National Tritium Labeling Facility & 110 & NW & $2.7 \times 10^{-3}$ & $97.2 \%$ \\
\hline $55 / 56$ & Research Medicine/BIF & 490 & $E$ & $5.0 \times 10^{-5}$ & $1.8 \%$ \\
\hline 85 & $\begin{array}{l}\text { New Hazardous Waste Handling } \\
\text { Facility }\end{array}$ & 730 & WNW & $8.6 \times 10^{-6}$ & $.3 \%$ \\
\hline $75 \mathrm{~A} / 75$ & $\begin{array}{l}\text { Old Hazardous Waste Handling } \\
\text { Facility }\end{array}$ & 150 & NW & $2.1 \times 10^{-6}$ & $0.1 \%$ \\
\hline 88 & 88-Inch Cyclotron & 670 & ENE & $3.6 \times 10^{-6}$ & $0.1 \%$ \\
\hline $70 / 70 \mathrm{~A}$ & Nuclear / Life Sciences & 510 & NE & $1.9 \times 10^{-6}$ & $0.1 \%$ \\
\hline 74/74B/83 & $\begin{array}{l}\text { Buildings } 74 / 74 \mathrm{~B} / 83 \text { Research } \\
\text { Medicine }\end{array}$ & 730 & WNW & $7.2 \times 10^{-10}$ & $0.1 \%$ \\
\hline 1 & Donner Laboratory (UC Berkeley) & 980 & ENE & $1.2 \times 10^{-5}$ & $0.4 \%$ \\
\hline $2 / 6$ & Advanced Material Laboratory/ALS & 370 & NE & $2.5 \times 10^{-7}$ & $<0.1 \%$ \\
\hline $26 / 76$ & RAML/Counting Laboratory & 240 & $\mathbf{N}$ & $6.2 \times 10^{-10}$ & $<0.1 \%$ \\
\hline 934 & $\begin{array}{l}\text { Molecular and Cell Biology } \\
\text { (off site) }\end{array}$ & 4,900 & ENE & $1.8 \times 10^{-9}$ & $<0.1 \%$ \\
\hline $71 / 72$ & HILAC/NCEM & 220 & $E$ & 0.0 & $0 \%$ \\
\hline 3 & Calvin Lab (UC Berkeley) & 1,070 & NE & $2.9 \times 10^{-11}$ & $<0.1 \%$ \\
\hline $75 \mathrm{C}$ & EHS Calibration Sources & 150 & NW & 0.0 & $0 \%$ \\
\hline \multirow[t]{2}{*}{903} & Receiving Warehouse & N/A & N/A & 0.0 & $0 \%$ \\
\hline & & & Total & $2.78 \times 10^{-3}$ & $100 \%$ \\
\hline
\end{tabular}

the areas. This approach projected a total collective population dose from all airborne radionuclides at $2.52 \times 10^{-2}$ person-Sv (2.52 person-rem).

\section{$\$ 10.6$ IV. COMBINED DOSE ASSESSMENT}

The total radiological impact from accelerator operations and airborne radionuclides is well below applicable standards and nominal background radiation. As presented in Table 10-4 and Figure 10-2, the maximum effective dose equivalent to an individual from all Berkeley Lab operations in 1998 is about $0.007 \mathrm{mSv}(0.7 \mathrm{mrem})$ per year. This value is about $0.3 \%$ of the nominal background 5 in the Bay Area and less than $1 \%$ of the DOE annual limits. ${ }^{6}$ The estimated dose to the population within 80 kilometers of Berkeley Lab from these same activities was $2.56 \times 10^{-2}$ person-Sv (2.56 person-rem) in 1998 . With the dose from natural background sources alone to this same population base estimated at 13,000 person-SV (1,300,000 person-rem) for the same period, the Laboratory's collective population dose is a mere $0.0002 \%$ of the background level. 
Table 10-4 Summary of Radiological Dose Impacts

\begin{tabular}{l|ccc}
\hline & $\begin{array}{c}\text { Maximally } \\
\text { exposed individual } \\
\text { (direct radiation) }\end{array}$ & $\begin{array}{c}\text { Maximally } \\
\text { exposed individual } \\
\text { (airborne nuclides) }\end{array}$ & $\begin{array}{c}\text { Maximally } \\
\text { exposed individual } \\
\text { (direct and airborne) }\end{array}$ \\
\hline Annual EDE & $0.004 \mathrm{mSv} / \mathrm{yr} \mathrm{b}^{\mathrm{b}}$ & $0.003 \mathrm{mSv} / \mathrm{yr}$ & $0.007 \mathrm{mSv} / \mathrm{yr}$ \\
\hline MEl location & $\begin{array}{c}\text { Residence } \\
(110 \text { meters west of } \\
\text { Bldg. } 88)\end{array}$ & $\begin{array}{c}\text { Workplace } \\
(110 \text { meters } \\
\text { northwest of } \\
\text { Bldg. } 75 \text { at Lawrence } \\
\text { Hall of Science) }\end{array}$ & $\begin{array}{c}\text { Residence } \\
(110 \text { meters west of } \\
\text { Bldg. 88) }\end{array}$ \\
\hline $\begin{array}{l}\text { Standard of } \\
\text { comparison }\end{array}$ & $\begin{array}{c}1 \mathrm{mSv} / \mathrm{yr} \\
\text { (DOE) }\end{array}$ & $\begin{array}{c}0.10 \mathrm{mSv} / \mathrm{yr} \\
(\mathrm{US} / \mathrm{EPA})\end{array}$ & $\begin{array}{c}1 \mathrm{mSv} / \mathrm{yr} \\
\text { (DOE) }\end{array}$ \\
\hline $\begin{array}{l}\text { Impact as } \% \text { of } \\
\text { standard }\end{array}$ & $0.4 \%$ & $3 \%$ & $0.7 \%$ \\
\hline $\begin{array}{l}\text { Annual } \\
\text { background }\end{array}$ & $1 \mathrm{mSv} / \mathrm{yr}$ & $1.6 \mathrm{mSv} / \mathrm{yr}$ & $2.6 \mathrm{mSv} / \mathrm{yr}$ \\
\hline $\begin{array}{l}\text { Impact as } \% \text { of } \\
\text { background }\end{array}$ & $0.4 \%$ & $0.2 \%$ & $0.3 \%$ \\
\hline
\end{tabular}

a $E D E=$ Effective Dose Equivalent

${ }^{b} 1 \mathrm{mSv}=100 \mathrm{mrem}$

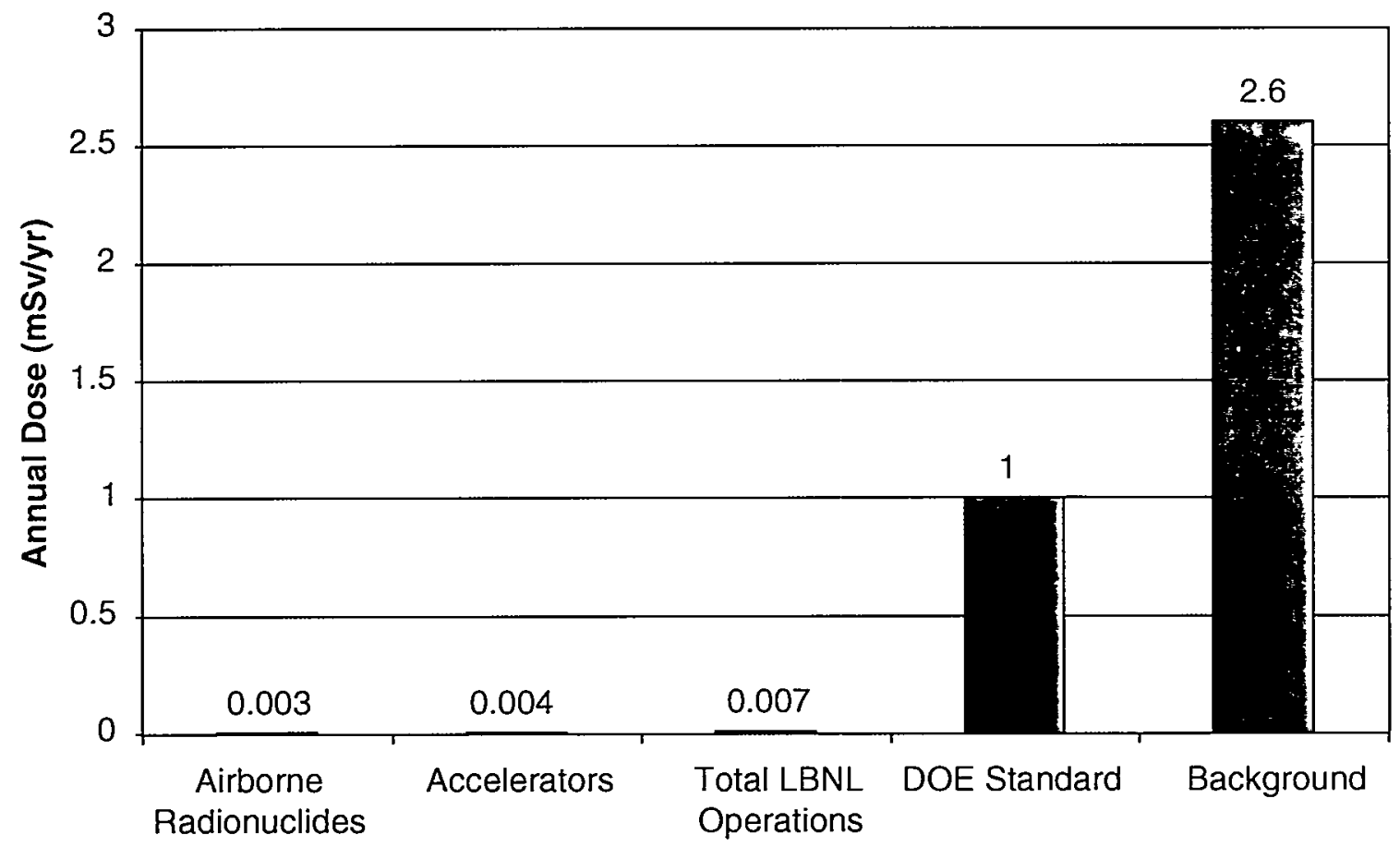

Figure 10-2 Comparison of Radiological Dose Impact 


\section{1 \\ Quality Assurance}

I. BACKGROUND $\$ 11.1$

II. SAMPLE COLLECTION $\$ \mathbf{\$ 1 1 . 2}$

III. SAMPLE ANALYSIS $\$ 11.3$

IV. DATA QUALITY ASSESSMENT $\$ \mathbf{\$ 1 . 4}$

V. OVERSIGHT OF ENVIRONMENTAL MONITORING QUALITY ASSURANCE $\$ 11.5$

VI. SUMMARY \$11.6

\section{$\$ 11.1$ I. BACKGROUND}

Quality assurance (QA) activities and processes ensure that environmental monitoring data meet user requirements. Quality control (QC) procedures verify that Berkeley Lab attains prescribed standards of performance for environmental monitoring. This chapter contains a summary discussion of QA and QC activities performed routinely by the environmental monitoring program in support of the Site Environmental Report.

Berkeley Lab's policy on QA is documented in the Operating and Assurance Plan (OAP). ${ }^{1}$ The OAP consists of a set of operating principles used to support internal organizations in achieving consistent, safe, and high-quality performance in their work activities. OAP principles are applied to individual programs using a graded approach, with consideration given to factors such as the program's environmental, health, and safety consequences; its programmatic significance; and its mission.

In addition to the OAP, the monitoring and sampling activities and results presented in this report were conducted in accordance with Berkeley Lab's Environmental Monitoring Plan (EMP) ${ }^{2}$ and applicable $\mathrm{DOE}^{3}$ and US/EPA ${ }^{4}$ guidance. When special QA/QC requirements are necessary for environmental monitoring (such as NESHAPs stack monitoring) a Quality Assurance Project Plan (QAPP) is developed and implemented.

As discussed in \$3.9, the Environmental Protection Agency has requested additional sampling of the air, water, and soil in and around the Laboratory to help determine whether to include Berkeley Lab on the Superfund List. QAPPs for this EPA-requested sampling will be developed in 1999. 


\section{$\$ 11.2$ II. SAMPLE COLLECTION}

Berkeley Lab's environmental monitoring program collects samples in accordance with the specifications of the EMP. Documented implementation procedures are used for performing sample collection. These procedures prescribe sampling collection methods and related requirements for obtaining representative matrix samples. The following requirements are integrated into the sample collection procedures:

- EPA- or internally-developed methods are used to obtain representative matrix samples;

- Qualified and experienced field staff perform the sample collections using standard procedures and calibrated sampling instrumentation;

- All necessary field-sampling information is documented on chain-of-custody forms and other field notes;

- Samples are packaged and shipped to analytical laboratories using standard and documented handling procedures and containers that preserve sample integrity;

- When possible, field QC samples (i.e., duplicates, splits, blanks) are submitted to analytical laboratories with each batch of samples; and

- Sample disposition and status are tracked using chain-of-custody sheet information.

\section{$\$ 11.3$ III. SAMPLE ANALYSIS}

Berkeley Lab utilizes on-site and off-site (contract) laboratories to analyze samples for the environmental monitoring program. Both types of laboratories must meet demanding QA/QC specifications and certifications ${ }^{5}$ that were established to define, monitor, and document laboratory performance. The QA/QC data provided by these laboratories are incorporated into the data quality-assessment processes.

The following list is a summary of $\mathrm{QA} / \mathrm{QC}$ requirements that analytical laboratories supporting the environmental monitoring program must meet:

- The laboratory must have a written and implemented QA/QC plan that meets Berkeley Lab requirements and specifications.

- The laboratory must be certified by the California Department of Health Services Environmental Laboratory Accreditation Program.

- The laboratory must participate in inter-laboratory QA programs such as the Environmental Monitoring Sampling Laboratory and the Department of Energy (DOE) Environmental Measurement Laboratory. Berkeley Lab reviews results from these programs and initiates follow-up actions when data do not fall within satisfactory limits.

- The laboratory must meet the following documented internal $\mathrm{QC}$ requirements (when applicable):

(a) Control limits;

(b) Method detection limit studies;

(c) Matrix spikes, matrix spike duplicates, and laboratory control samples;

(d) Method blanks;

(e) Surrogates; 
(f) Initial and ongoing calibration checks; and

(g) Sample duplicates.

- The laboratory must have documented analytical control limits approved by Berkeley Lab, along with the basis for the control limits, derivation of method, and method for retaining control limits. Berkeley Lab uses these control limits to assess analytical data quality.

- The laboratory must analyze performance evaluation samples submitted by Berkeley Lab. Results from these samples are reviewed by Berkeley Lab, which initiates follow-up actions when data do not fall within satisfactory limits.

- The laboratory must participate in annual audits and assessments by Berkeley Lab personnel or other designated staff, with formal written reports that summarize findings and requirements for follow-up actions.

- Laboratory deliverables must include the following items:

(a) Case narratives;

(b) Chain-of-custody documentation;

(c) Sample and hard-copy retention; and

(d) Summary of results, QC data, and data validation (electronic data deliverables).

\section{$\$ 11.4$ IV. DATA QUALITY ASSESSMENT}

Each set of data (batch) received from the analytical laboratory is systematically evaluated and compared to established data quality objectives. Data quality is assessed for each analytical batch before the results can be authenticated and accepted into the environmental monitoring database. Categories of data quality objectives include accuracy, precision, representativeness, comparability, and completeness. When possible, quantitative criteria are used to define and assess data quality.

To perform the large number of QC checks necessary to determine whether data quality objectives have been achieved, the electronic data deliverables provided by the analytical laboratories are uploaded into a Berkeley Lab environmental monitoring database. This database is used to perform computer-automated data quality checks that interrogate the laboratory data package for QC results. Data quality discrepancies are flagged, investigated, and resolved by Berkeley Lab staff. Following the automated data validation/verification checks and any necessary discrepancy resolution, Berkeley Lab environmental monitoring specialists perform final data authentication by reviewing the data and QC results before they are accepted.

\section{\$11.5 V. OVERSIGHT OF ENVIRONMENTAL MONITORING QUALITY ASSURANCE}

To verify that environmental monitoring activities are adequate and effective, internal and external oversight is performed as required on specific environmental monitoring programs. Internal oversight activities consist of technical QA assessments performed by the Environmental Protection Group and internal independent assessments conducted by the Berkeley Lab Office of Assessment and Assurance. 
DOE's external oversight of Berkeley Lab programs is performed through the Operational Awareness Program. ${ }^{6}$ Operational awareness activities include field orientation, meetings, audits, workshops, document and information system reviews, and day-to-day communications. DOE criteria for performance evaluation include federal, state, and local regulations with general applicability to DOE facilities and applicable DOE requirements. In addition, US/EPA conducts external audits of the NESHAPs monitoring program under $40 \mathrm{CFR} 61$, Subpart $\mathrm{H}$.

\section{$\$ 11.6$ VI. SUMMARY}

Quality assurance for environmental monitoring at Berkeley Lab is a continuous and comprehensive process designed to ensure that monitoring results meet documented requirements. All results generated and reported by the environmental monitoring program undergo a stringent data quality assessment to verify that data quality objectives are met. Throughout the QA process, data quality checks and communication links are in place to identify, document, and correct data quality discrepancies. 


\section{Chapter 1: Executive Summary}

1. U.S. Department of Energy, Environment, Safety, and Health Reporting, DOE Order 231.1 (1995, amended 1997).

2. U.S. Department of Energy, Contract Between the United States of America and the Regents of the University of California, DE-AC03-76SF00098/M145 (October 1997).

3. Ernest Orlando Lawrence Berkeley National Laboratory, Contract 98 Appendix F Self-Assessment Report for Fiscal Year 1998, Pub 3138 (September 1998).

4. Ernest Orlando Lawrence Berkeley National Laboratory, Environmental Monitoring Plan, Environmental Protection Group (October 1997).

5. U.S. Department of Energy, Radiation Protection of the Public and the Environment, DOE Order 5400.5 (1990, amended 1993).

6. Committees on the Biological Effects of Ionizing Radiations (BEIR V), Health Effects of Exposure to Low Levels of Ionizing Radiation, National Academy Press (1990).

7. U.S. Environmental Protection Agency, National Emission Standard for Emissions of Radionuclides Other Than Radon from Department of Energy Facilities, Title 40 Code of Federal Regulations (CFR) Part 61, Subpart H (1989).

8. East Bay Municipal Utility District, Wastewater Discharge Permits (Account Numbers 0660079 1, 5023891 1, 5023892 1, and 5034789 1) for Lawrence Berkeley National Laboratory (September 1997).

9. California State Water Resources Control Board, General Permit for Stormwater Discharges Associated With Industrial Activity (No. 2 01S002421), Water Quality Order 97-03-DWQ NPDES General Permit Number CAS 000001 (1997).

10. California Regional Water Quality Control Board, San Francisco Region Basin Plan (June 1995).

\section{Chapter 2: Introduction}

The Ernest Orlando Lawrence Berkeley National Laboratory Institutional Plan FY19962001 (November 1995) was used to obtain background information presented in this chapter. In addition, the Association of Bay Area Government's Web site (http://www.abag.ca.gov/) provided access to vital statistics on the Bay Area and its communities, including the latest population census figures. 


\section{Chapter 3: Environmental Program Summary}

1. U.S. Department of Energy, Occurrence Reporting and Processing of Operations Information, DOE Order 232.1A (July 1997).

2. Clean Air Act, 42 United States Code (USC) $\$ 7401$ et seq. (1967, as amended).

3. Air Resources, California Health and Safety Code $\$ 39000$ et seq. (1967, as amended).

4. U.S. Environmental Protection Agency, National Emission Standard for Emissions of Radionuclides Other Than Radon from Department of Energy Facilities, 40 CFR Part 61, Subpart H (1989).

5. U.S. Department of Energy, General Environmental Protection Program, DOE Order 5400.1 (1988, amended 1990).

6. U.S. Department of Energy, Radiation Protection of the Public and the Environment, DOE Order 5400.5 (1990, amended 1993).

7. U.S. Department of Energy, Environmental Regulatory Guide for Radiological Effluent Monitoring and Environmental Surveillance, DOE/EH-0173T (January 1991).

8. Bay Area Air Quality Management District, Permit to Operate for Lawrence Berkeley National Laboratory (Plant \#723 and G \#6134) (July 1998).

9. Air Toxics "Hot Spots" Information and Assessment, California Health and Safety Code $\$ 44300$ et seq. (1987, as amended).

10. Comprehensive Environmental Response, Compensation, and Liability Act of 1980, 42 USC $\$ 9601$ et seq. (1980, as amended).

11. Resource Conservation and Recovery Act, Subchapter III, Hazardous Waste Management, 42 USC $\$ 6921$ et seq. (1976, as amended).

12. Emergency Planning and Community Right-To-Know Act of 1986, 42 USC $\$ 11001$ et seq. (1986, as amended).

13. Hazardous Materials Release Response Plans and Inventory Law, California Health and Safety Code $\$ 25500$ et seq. (1985, as amended).

14. U.S. Executive Order 12856, Federal Compliance with Right-To-Know Laws and Pollution Prevention Requirements, 58 FR 41901 (August 3, 1993).

15. Ernest Orlando Lawrence Berkeley National Laboratory, Hazardous Materials Management Plan, Bio/Sciences Group (July 1997).

16. Risk Management and Prevention Program, California Health and Safety Code $\$ 25531$ et seq.

17. Federal Insecticide, Fungicide, and Rodenticide Act, 7 USC $\$ 136$ et seq. (1972, as amended).

18. Toxic Substances Control Act, 15 USC $\$ 2601$ et seq. (1976, as amended).

19. Resource Conservation and Recovery Act, 42 USC $\$ 6901$ et seq. (1976, as amended).

20. Hazardous Waste Control Law, California Health and Safety Code $\$ 25100$ et seq. (1972, as amended).

21. California Environmental Protection Agency, Hazardous Waste Facility Permit, EPA ID Number CA 4890008986, Department of Toxic Substances Control May 4, 1993).

22. California Department of Toxic Substances Control, Permit Renewal Notification for Lawrence Berkeley Laboratory (EPA ID\# CA4890008986) (April 1997). 
23. Ernest Orlando Lawrence Berkeley National Laboratory, Biennial Hazardous Waste Report for 1997, Waste Management Group (February 1998).

24. Ernest Orlando Lawrence Berkeley National Laboratory, Goals, Accomplishments, and Plans; WMINRS Waste Reduction Tables, Waste Management Group (June 1998; http://www-ehs.lbl.gov/wastemin/goals.html).

25. Ernest Orlando Lawrence Berkeley National Laboratory, Mixed Waste Site Treatment Plan, Waste Management Group (October 1995).

26. Ernest Orlando Lawrence Berkeley National Laboratory, RCRA Facility Investigation Work Plan for the Lawrence Berkeley Laboratory, Environmental Restoration Program (October 1992).

27. Ernest Orlando Lawrence Berkeley National Laboratory, Addendum to the RCRA Facility Investigation (Phase III) for Investigation of Soil Contamination and Construction of Groundwater Monitoring Wells, Environmental Restoration Program (March 1998); and Ernest Orlando Lawrence Berkeley National Laboratory, Addendum to the RCRA Facility Investigation (Phase III) for Construction of Groundwater Monitoring Wells MW25A-98-6, MW25A-98-7, MW52A-98-8, MW5298-9, MW25-98-10, MW46A-98-11, MW46A-98-12, MW71B-98-13, MW75-98-14, MW75-98-15, MW75-98-16, MW31-98-17, MW63-98-18, MW64-98-19, MW64-9820, $M W 76-98-21$, and $M W 76-98-22$, Environmental Restoration Program (August 1998).

28. Ernest Orlando Lawrence Berkeley National Laboratory, Investigation/Interim Corrective Measures (ICM) Workplan for the Building 51 Motor Generator Room, Environmental Restoration Program (January 1998); Ernest Orlando Lawrence Berkeley National Laboratory, Interim Corrective Measures (ICM) Workplan, Building 7E Former Diesel UST Site, Environmental Restoration Program (February 1998); Ernest Orlando Lawrence Berkeley National Laboratory, Interim Corrective Measures (ICM) Workplan for the Old Town Groundwater Contamination Plume, Environmental Restoration Program (March 1998); and Ernest Orlando Lawrence Berkeley National Laboratory, Interim Corrective Measures (ICM) Workplan for PCB Removals at the Building 17 Former Scrapyard and Drum Storage Area (SWMU 2-3) and Building 75 Former Hazardous Waste Handling and Storage Facility (SWMU 3-6), Environmental Restoration Program (September 1998).

29. Ernest Orlando Lawrence Berkeley National Laboratory, Draft Final RCRA Facility Investigation Report for the Lawrence Berkeley National Laboratory, Environmental Restoration Program (February 1997).

30. Ernest Orlando Lawrence Berkeley National Laboratory, Quarterly Progress Report, Fourth Quarter Fiscal Year 1997 (July 1 to September 30, 1997) for the LBNL Hazardous Waste Facility Permit, Environmental Restoration Program (February 1998); Ernest Orlando Lawrence Berkeley National Laboratory, Quarterly Progress Report, First Quarter Fiscal Year 1998 (October 1 to December 31, 1997) for the LBNL Hazardous Waste Facility Permit, Environmental Restoration Program (May 1998); Ernest Orlando Lawrence Berkeley National Laboratory, Quarterly Progress Report, Second Quarter Fiscal Year 1998 (January 1 to March 31, 1998) for the LBNL Hazardous Waste Facility Permit, Environmental Restoration Program (August 1998); and Ernest Orlando Lawrence Berkeley National Laboratory, Quarterly Progress Report, Third Quarter Fiscal Year 1998 (April 1 to June 30, 1998) for the LBNL Hazardous Waste Facility Permit, Environmental Restoration Program (November 1998). 
31. Medical Waste Management Act, California Health and Safety Code $\$ 25015$ et seq. (1991, as amended).

32. Underground Storage of Hazardous Substances, California Health and Safety Code $\$ 25280$ et seq. (1983, as amended).

33. Resource Conservation and Recovery Act, Subchapter IX, Regulation of Underground Storage Tanks, 42 USC $\$ 6991$ (1988, as amended).

34. U.S. Executive Order 12873, Federal Acquisition, Recycling, and Waste Prevention, 58 FR 54911 (October 22, 1993).

35. Hazardous Waste Source Reduction and Management Review Act of 1989, California Health and Safety Code $\$ 25244.12$ et seq. (1989).

36. Ernest Orlando Lawrence Berkeley National Laboratory, Source Reduction Evaluation Review Plan and Plan Summary, Waste Management Group (August 1995).

37. Ernest Orlando Lawrence Berkeley National Laboratory, Hazardous Waste Management Report Summary, Waste Management Group (August 1995).

38. Pollution Prevention Act of 1990, 42 USC $\$ 13101$ et seq. (1990).

39. Clean Water Act, 33 USC $\$ 1251$ et seq. (1977, as amended).

40. Porter-Cologne Water Quality Control Act, California Water Code $\$ 13020(1969$, as amended).

41. East Bay Municipal Utility District, Wastewater Discharge Permits (Account Numbers 0660079 1, 5023891 1, 50238921 (September 1998), and 50347891 (September 1997)) for Lawrence Berkeley National Laboratory.

42. Ernest Orlando Lawrence Berkeley National Laboratory, Toxic Organics Management Plan, Building 25 Photo Fabrication Facility, Environmental Protection Group (May 1997).

43. Ernest Orlando Lawrence Berkeley National Laboratory, Accidental Spill Prevention and Containment Plan, Volumes I through V, Environmental Protection Group (1994-1998).

44. Ernest Orlando Lawrence Berkeley National Laboratory, Accidental Spill Prevention and Containment Plan/Toxic Organics Management Plan, Environmental Protection Group (December 1997).

45. California State Water Resources Control Board, General Permit for Stormwater Discharges Associated With Industrial Activity (No. 2 01S002421), Water Quality Order 97-03-DWQ NPDES General Permit Number CAS 000001 (1997).

46. Ernest Orlando Lawrence Berkeley National Laboratory, Storm Water Pollution Prevention Plan, Environmental Protection Group (June 1998).

47. Ernest Orlando Lawrence Berkeley National Laboratory, Storm Water Monitoring Program, Environmental Protection Group (June 1997).

48. Ernest Orlando Lawrence Berkeley National Laboratory, 1997-1998 Annual Report for Stormwater Discharges Associated with Industrial Activities, Environmental Protection Group (July 1998).

49. Clean Water Act, 33 USC $\$ 1251$ et seq. (1977, as amended).

50. Aboveground Petroleum Storage Act, California Health and Safety Code $\$ 25270$ et seq. (1989, as amended).

51. Safe Drinking Water Act, 42 USC $\$ 300$ f et seq. (1974, as amended).

52. Ernest Orlando Lawrence Berkeley National Laboratory, Contract 98 Appendix $F$ Self-Assessment Report for Fiscal Year 1998, PUB-3138 (September 1998). 


\section{Chapter 4: Air Quality}

1. U.S. Environmental Protection Agency, National Emission Standard for Emissions of Radionuclides Other Than Radon from Department of Energy Facilities, 40 CFR Part 61, Subpart H (1989).

2. U.S. Department of Energy, General Environmental Protection Program, DOE Order 5400.1 (1988, amended 1990).

3. U.S. Department of Energy, Radiation Protection of the Public and the Environment, DOE Order 5400.5 (1990, amended 1993).

4. Ernest Orlando Lawrence Berkeley National Laboratory, Environmental Monitoring Plan, Environmental Protection Group (October 1997).

5. U.S. Environmental Protection Agency, Designation, Reportable Quantities, and Notification, 40 CFR Part 302, Appendix B (1989).

6. U.S. Department of Energy, Radiation Protection of the Public and the Environment, DOE Order 5400.5 (1990, amended 1993).

\section{Chapter 5: Surface Water}

1. U.S. Department of Energy, General Environmental Protection Program, DOE Order 5400.1 (1988, amended 1990); and U.S. Department of Energy, Radiation Protection of the Public and the Environment, DOE Order 5400.5 (1990, amended 1993).

2. California State Water Resources Control Board, General Permit for Stormwater Discharges Associated With Industrial Activity (No. 2 01S002421), Water Quality Order 97-03-DWQ NPDES General Permit Number CAS 000001 (1997).

3. U.S. Environmental Protection Agency, National Primary Drinking Water Standards, 40 CFR Part 141, Subpart B (1976); and California State Department of Health Services, Domestic Water Quality and Monitoring Regulations, Title 22 California Code of Regulations (CCR) $\$ 64443$ (1984, as amended).

4. U.S. Environmental Protection Agency, National Primary Drinking Water Standards, 40 CFR Part 141, Subpart B (1976).

5. California State Water Resources Control Board, General Permit for Stormwater Discharges Associated With Industrial Activity (No. 2 01S002421), Water Quality Order 97-03-DWQ NPDES General Permit Number CAS 000001 (1997).

6. Ernest Orlando Lawrence Berkeley National Laboratory, Storm Water Monitoring Program, Environmental Protection Group (June 1997).

7. Ernest Orlando Lawrence Berkeley National Laboratory, Storm Water Pollution Prevention Plan, Environmental Protection Group (June 1998).

8. California Regional Water Quality Control Board, San Francisco Region Basin Plan (June 1995).

\section{Chapter 6: Groundwater Protection}

1. Science Applications International Corporation, Groundwater Protection Management Program Plan for Lawrence Berkeley Laboratory (July 1991).

2. Resource Conservation and Recovery Act, Subchapter III, Hazardous Waste Management, 42 USC $\$ 6921$ et seq. (1976, as amended). 
3. Ernest Orlando Lawrence Berkeley National Laboratory, RCRA Facility Investigation Phase I Progress Report, Environmental Restoration Program (November 1994).

4. U.S. Environmental Protection Agency, National Primary Drinking Water Standards, 40 CFR Part 141, Subpart B (1976); and California State Department of Health Services, Domestic Water Quality and Monitoring Regulations, 22 CCR $\$ 64443$ et seq. (1984, as amended).

5. U.S. Environmental Protection Agency, National Primary Drinking Water Standards, 40 CFR Part 141, Subpart B (1976).

6. East Bay Municipal Utility District, Wastewater Discharge Permit (Account Number 503-47891) for Lawrence Berkeley National Laboratory (September 1997).

\section{Chapter 7: Sanitary Sewer}

1. East Bay Municipal Utility District, Wastewater Discharge Permits (Account Numbers 0660079 1, 5023891 1, 5023892 1, and 5034789 1) for Lawrence Berkeley National Laboratory (September 1997).

2. U.S. Department of Energy, Environmental Regulatory Guide for Radiological Effluent Monitoring and Environmental Surveillance, DOE/EH-0173T (January 1991).

3. U.S. Department of Energy, General Environmental Protection Program, DOE Order 5400.1 (1988, amended 1990); and U.S. Department of Energy, Radiation Protection of the Public and the Environment, DOE Order 5400.5 (1990, amended 1993).

4. Standards for Protecting Against Radiation, 17 CCR $\$ 30253$ (1994).

5. U.S. Nuclear Regulatory Commission, Standards for Protection Against Radiation, 10 CFR 20, Subpart K (1994).

\section{Chapter 8: Soil and Sediment}

1. U.S. Department of Energy, Environmental Regulatory Guide for Radiological Effluent Monitoring and Environmental Surveillance, DOE/EH-0173T (January 1991).

2. Ernest Orlando Lawrence Berkeley National Laboratory, Environmental Monitoring Plan, Environmental Protection Group (October 1997).

3. California State Department of Toxic Substances Control, Characteristics of Hazardous Waste, 22 CCR \$66261.24 (1991, as amended).

\section{Chapter 9: Vegetation and Foodstuffs}

1. U.S. Department of Energy, Environmental Regulatory Guide for Radiological Effluent Monitoring and Environmental Surveillance, DOE/EH-0173T (January 1991).

2. Ernest Orlando Lawrence Berkeley National Laboratory, Environmental Monitoring Plan, Environmental Protection Group (October 1997).

3. Ernest Orlando Lawrence Berkeley National Laboratory, Site Environmental Report for 1997, Volume I, LBNL-27170 (1998). 
4. Ernest Orlando Lawrence Berkeley National Laboratory, Site Environmental Report for 1996, Volume I, LBNL-27170 (1997).

5. Ernest Orlando Lawrence Berkeley National Laboratory, Tree Sampling and Tritium Analysis Plan, Environmental Protection Group (1998).

\section{Chapter 10: Radiological Dose Assessment}

1. Kathren, R.L., Radioactivity in the Environment: Sources, Distribution, and Surveillance, Harwood Academic Publishers (1984).

2. Thomas, R.H., The Environmental Surveillance Program of the Lawrence Berkeley Laboratory, LBL-4678 (1976).

3. U.S. Department of Commerce, Bureau of the Census, Census Tracts; San Francisco-Oakland, California (et al.), Standard Metropolitan Statistical Area (SMSA), PHC-80-2-231 (1983); and U.S. Department of Commerce, Bureau of the Census, Characteristics of the Population: Number of Inhabitants, California 1980, PC-801-AC (1982).

4. U.S. Department of Energy EH-232, CAP88-PC, Version 1.0 (March 1992).

5. Committees on the Biological Effects of Ionizing Radiations (BEIR V), Health Effects of Exposure to Low Levels of Ionizing Radiation, National Academy Press (1990).

6. U.S. Department of Energy, Radiation Protection of the Public and the Environment, DOE Order 5400.5 (1990, amended 1993).

\section{Chapter 11: Quality Assurance}

1. Ernest Orlando Lawrence Berkeley National Laboratory, Operating and Assurance Plan, Pub 3111, Revision 5 (January 1998).

2. Ernest Orlando Lawrence Berkeley National Laboratory, Environmental Monitoring Plan, Environmental Protection Group (October 1997).

3. U.S. Department of Energy, Environmental Regulatory Guide for Radiological Effluent Monitoring and Environmental Surveillance, DOE/EH-0173T (January 1991).

4. U.S. Environmental Protection Agency, National Emission Standard for Emissions of Radionuclides Other Than Radon from Department of Energy Facilities, 40 CFR Part 61, Subpart H (1989).

5. Lawrence Livermore National Laboratory, Statement of Work for Analytical Services in Support of the Environmental Protection Department (July 1995).

6. U.S. Department of Energy, Operational Awareness Guide, Berkeley Site Office (November 1997). 


\section{Acronyms and Abbreviations}

AEDE

ALARA

ALS

ANSI

ASPCP

AST

BAAQMD

Basin Plan

Berkeley Lab

$\mathrm{Bq}$

BTEX

${ }^{\circ} \mathrm{C}$

CAA

$\mathrm{Cal} / \mathrm{EPA}$

CCR

CEDE

CEQA

CERCLA

CFR

$\mathrm{Ci}$

Clean Air Act

$\mathrm{cm}$

CMTW

$\mathrm{COB}$

CODF

CUPA
Ánnual Effective Dose Equivalent

As Low As Reasonably Achievable

Advanced Light Source

American National Standards Institute

Accidental Spill Prevention and Containment Plan

Aboveground Storage Tank

Bay Area Air Quality Management District

Water Quality Control Plan

Ernest Orlando Lawrence Berkeley National Laboratory

Becquerel

Benzene, Toluene, Ethylbenzene, and Xylene

degrees Celsius

Clean Air Act

California Environmental Protection Agency

California Code of Regulations

Collective Effective Dose Equivalent

California Environmental Quality Act

Comprehensive Environmental Response, Compensation, and Liability Act

Code of Federal Regulations

Curie

Air Quality

centimeter

Committee to Minimize Toxic Waste

City of Berkeley

chemical oxygen demand, filtered

Certified Unified Program Agency 


\begin{tabular}{ll} 
CWA & Clean Water Act \\
CY & Calendar Year \\
DHS & Department of Health Services \\
DOE & U.S. Department of Energy \\
DOE/BSO & U.S. Department of Energy/Berkeley Site Office \\
DOE/OAK & U.S. Department of Energy/Oakland Operations Office \\
DOT & U.S. Department of Transportation \\
DTSC & Department of Toxic Substances Control \\
EBMUD & East Bay Municipal Utility District \\
EDE & Effective Dose Equivalent \\
EH\&S & Environment, Health, and Safety \\
EM & Environmental Management \\
EMP & Environmental Monitoring Plan \\
EMS & Environmental Monitoring Station \\
EPCRA & Emergency Planning and Community Right-to-Know Act \\
EPG & Environmental Protection Group \\
EPM & Environmental Monitoring Plan \\
ERP & Environmental Restoration Program \\
ERWM & Environmental Restoration and Waste Management \\
ES\&H & Environment, Safety, and Health \\
$F$ & degrees Fahrenheit \\
FIFRA & Federal Insecticide, Fungicide, and Rodenticide Act \\
ft & foot or feet \\
FTU & Fixed Treatment Unit \\
FWT & free water tritium \\
FY & Fiscal Year \\
gpm & gallons per minute \\
gsf & gross square feet \\
gsm & gross square meters \\
HEPA & High Efficiency Particulate Air \\
HGL & Human Genome Laboratory \\
HMMP & Hazardous Materials Management Plan \\
\hline
\end{tabular}




\begin{tabular}{|c|c|}
\hline $\mathrm{HT}$ & Tritiated Hydrogen Gas \\
\hline HTO & Tritium Oxide (Tritiated Water) \\
\hline HWHF & Hazardous Waste Handling Facility \\
\hline ICMs & Interim Corrective Measures \\
\hline INEEL & Idaho National Engineering and Environmental Laboratory \\
\hline in & inch \\
\hline $\mathrm{kg}$ & kilogram \\
\hline $\mathrm{km}$ & kilometer \\
\hline $\mathrm{L}$ & Liter \\
\hline LANL & Los Alamos National Laboratory \\
\hline LBNL & Lawrence Berkeley Laboratory \\
\hline LLNL & Lawrence Livermore National Laboratory \\
\hline $\mathrm{m}$ & meter \\
\hline MCL & Maximum Contamination Limit \\
\hline MDA & Minimum Detectable Activity \\
\hline MEI & Maximally Exposed Individual \\
\hline$\mu \mathrm{Ci}$ & microcurie \\
\hline$\mu g$ & microgram \\
\hline $\mathrm{mg}$ & milligram \\
\hline Mgsf & Million gross square feet \\
\hline $\mathrm{ml}$ & milliliter \\
\hline mrem & millirem \\
\hline MSDS & Material Safety Data Sheet \\
\hline $\mathrm{mSv}$ & millisievert \\
\hline MTBE & Methyl Tertiary Butyl Ether \\
\hline MW & Mixed Waste \\
\hline ND & non-detectable \\
\hline NERSC & National Energy Research Scientific Computer Center \\
\hline NESHAPs & National Emission Standards for Hazardous Air Pollutants \\
\hline NOV & Notice of Violation \\
\hline NPL & National Priorities List \\
\hline
\end{tabular}


NRC

NPDES

NTLF

OAP

OBT

ODS

$\mathrm{pCi}$

PCB

PCE

PM

POTW

ppbv

ppm

QA

QAPP

QC

RAML

RCRA

RFI

RMPP

RWQCB

SAA

SARA

SDWA

SI

SOP

STP

Sv

SWMP

SWPPP

SWRCB

$\mathrm{TBq}$
Nuclear Regulatory Commission

National Pollutant Discharge Elimination System

National Tritium Labeling Facility

Operating and Assurance Program

organically bound tritium

Ozone-Depleting Substance

picocurie (one billionth of a curie)

Polychlorinated Biphenyl

Perchloroethylene

Performance Measure

Publicly Owned Treatment Works

parts per billion by volume

parts per million

Quality Assurance

Quality Assurance Project Plan

Quality Control

Radiation and Analytical Measurements Laboratory

Resource Conservation and Recovery Act

RCRA Facility Investigation

Risk Management and Prevention Plan

Regional Water Quality Control Board

Satellite Accumulation Area

Superfund Amendments and Reauthorization Act

Safe Drinking Water Act

Systéme Internationale or International System of Units (the metric system)

Standard Operating Procedure

Site Treatment Plan

Sievert

Storm Water Monitoring Program

Storm Water Pollution Prevention Plan

State Water Resources Control Board

Terabecquerel (one trillionth of a Becquerel) 


$\begin{array}{ll}\text { TCE } & \text { Trichloroethylene } \\ \text { TDS } & \text { Total Dissolved Solids } \\ \text { TICH } & \text { Total Identifiable Chlorinated Hydrocarbons } \\ \text { TLD } & \text { Thermoluminescent Dosimeter } \\ \text { TOC } & \text { Total Organic Carbon } \\ \text { TOMP } & \text { Toxic Organic Management Plan } \\ \text { TPH } & \text { Total Petroleum Hydrocarbons } \\ \text { TPH-D } & \text { Total Petroleum Hydrocarbons, Diesel } \\ \text { TPH-G } & \text { Total Petroleum Hydrocarbons, Gasoline } \\ \text { TRI } & \text { Toxic Release Inventory } \\ \text { TSCA } & \text { Toxic Substance Control Act } \\ \text { TSS } & \text { total suspended solids } \\ \text { TTO } & \text { Total Toxic Organics } \\ \text { UC } & \text { University of California } \\ \text { UCB } & \text { University of California at Berkeley } \\ \text { UCOP } & \text { University of California Office of the President } \\ \text { UHVCF } & \text { Ultra-High Vacuum Cleaning Facility } \\ \text { URL } & \text { Uniform Resource Locator } \\ \text { US/EPA } & \text { U.S. Environmental Protection Agency } \\ \text { UST } & \text { Underground Storage Tank } \\ \text { UV } & \text { Ultraviolet } \\ \text { VOC } & \text { Volatile Organic Compound } \\ \text { WAA } & \text { Waste Accumulation Area } \\ \text { WERF } & \text { Waste Experimental Reduction Facility } \\ \text { WMG } & \text { Waste Management Group }\end{array}$




\section{Glossary}

\section{Accuracy}

The closeness of the result of a measurement to the true value of the quantity measured.

\section{Air particulates}

Airborne particles that include dust, dirt, and other pollutants that occur as particles, and any pollutants that may be associated with or carried on the dust or dirt.

\section{Aliquot}

An exact fractional portion of a sample taken for analysis.

\section{Alpha particle}

A charged particle, identical to the helium nucleus, comprising two protons and two neutrons that are emitted during decay of certain radioactive atoms. Alpha particles are stopped by several centimeters of air or a sheet of paper.

\section{Ambient air}

The surrounding atmosphere, usually the outside air, as it exists around people, plants, and structures. It does not include the air next to emission sources.

\section{Aquifer}

A saturated layer of rock or soil below the ground surface that can supply usable quantities of ground water to wells and springs. Aquifers can be a source of water for domestic, agricultural, and industrial uses.

\section{Background radiation}

Ionizing radiation from sources other than LBNL. Background may include cosmic radiation; external radiation from naturally occurring radioactivity in the earth (terrestrial radiation), air, and water; internal radiation from naturally occurring radioactive elements in the human body; and radiation from medical diagnostic procedures.

\section{Becquerel (Bq)}

Unit of radioactive decay equal to one disintegration per second (SI unit).

\section{Beta particle}

A charged particle, identical to the electron, that is emitted during decay of certain radioactive atoms. Most beta particles are stopped by less than 0.6 centimeters of aluminum.

\section{Categorical process}

An industrial process governed by federal regulation(s) of wastewater discharges.

\section{Collective effective dose equivalent}

The sum of the effective dose equivalents of all individuals in an exposed 
population within a certain radius, usually 80 kilometers for NESHAPs compliance. This value is expressed in units of person-sievert (SI) or person-rem (conventional).

\section{Contaminant}

Any hazardous or radioactive material present in an environmental medium such as air, water, or vegetation.

\section{Controlled area}

Any Laboratory area with controlled access to protect individuals from exposure to radiation and radioactive materials.

\section{Cosmic radiation}

High-energy particulate and electromagnetic radiation that originates outside the earth's atmosphere. Cosmic radiation is part of the natural background radiation.

\section{Curie}

Unit of radioactive decay equal to $2.22 \times 10^{12}$ disintegrations per minute (conventional units).

\section{Discharge}

A release of a liquid into an area not controlled by LBNL.

\section{Dose}

The quantity of radiation energy absorbed during a given period of time.

\section{Dose, absorbed}

The energy imparted to matter by ionizing radiation per unit mass of irradiated material. The unit of absorbed dose is the gray (SI) or rad (conventional).

\section{Dose, effective}

The hypothetical whole-body dose that would give the same risk of cancer mortality and/or serious genetic disorder as a given exposure and that may be limited to just a few organs. The effective dose equivalent is equal to the sum of individual organ doses, each weighted by degree of risk that the organ dose carries. For example, a 1-millisievert dose to the lung, which has a weighting factor of 0.12 , gives an effective dose that is equivalent to 0.12 millisievert $(1 \times 0.12)$.

\section{Dose, equivalent}

A term used in radiation protection that expresses all types of radiation (alpha, beta, and so on) on a common scale for calculating the effective absorbed dose. It is the product of the absorbed dose and certain modifying factors. The unit of dose equivalent is the sievert (SI) or rem (conventional).

\section{Dose, maximum boundary}

The greatest dose commitment, considering all potential routes of exposure, from a facility's operation to a hypothetical individual who is in an uncontrolled area where the highest dose rate occurs. It assumes that the hypothetical individual is present $100 \%$ of the time (full occupancy), and it does not take into account shielding by obstacles such as buildings or hillsides.

\section{Dose, maximum individual}

The greatest dose commitment, considering all potential routes of exposure, from a facility's operation to an individual at or outside the LBNL boundary where the highest dose rate occurs. It takes into account shielding and occupancy factors that would apply to a real individual. 


\section{Dose, population}

The sum of the radiation doses to individuals of a population. It is expressed in units of person-sievert (SI) or personrem (conventional). For example, if 1000 people each received a radiation dose of 1 sievert, their population dose would be 1000 person-sievert.

\section{Dosimeter}

A portable detection device for measuring the total accumulated exposure to ionizing radiation. See also Thermoluminescent dosimeter.

\section{Downgradient}

Commonly used to describe the flow of groundwater from higher to lower concentration. Analogous to "downstream."

\section{Effective dose equivalent}

Abbreviated EDE, it is the sum of the products of the dose equivalent received by specified tissues of the body and a tissue-specific weighting factor. This sum is a risk-equivalent value and can be used to estimate the health risk of the exposed individual. The tissue-specific weighting factor represents the fraction of the total health risk resulting from uniform whole-body irradiation that would be contributed by that particular tissue. The EDE includes the committed EDE from internal deposition of radionuclides and the EDE due to penetrating radiation from sources external to the body. EDE is expressed in units of sievert (SI) or rem (conventional).

\section{Effluent}

A liquid waste discharged to the environment.

\section{Emission}

A release of air to the environment containing gaseous or particulate matter having one or more contaminants.

\section{Environmental remediation}

The process of improving a contaminated area to a noncontaminated or safe condition.

\section{Exposure}

A measure of the ionization produced in air by X-ray or gamma radiation. The unit of exposure is the coulomb per kilogram (SI) or roentgen (conventional).

\section{External radiation}

Radiation originating from a source outside the body.

\section{Gamma radiation}

Short-wavelength electromagnetic radiation of nuclear origin that has no mass or charge. Because of its short wavelength (high energy), gamma radiation can cause ionization. Other electromagnetic radiation, such as microwaves, visible light, and radio waves, have longer wavelengths (lower energy) and cannot cause ionization.

\section{Groundwater}

A subsurface body of water in a zone of saturated soil sediments.

\section{Half-Life, radioactive}

The time required for the activity of a radioactive substance to decrease to half its value by inherent radioactive decay. After two half-lives, one-fourth of the original activity remains $(1 / 2 \times 1 / 2)$; after three half-lives, one-eighth of the original activity remains $(1 / 2 \times 1 / 2 \times$ $1 / 2)$; and so on. 


\section{Hazardous waste}

Waste exhibiting any of the following characteristics: ignitability, corrosivity, reactivity, or EP-toxicity (yielding toxic constituents in a leaching test). Because of its concentration, quantity, physical, or chemical characteristics, it may (1) cause or significantly contribute to an increase in mortality rates or cases of serious irreversible illness or (2) pose a substantial present or potential threat to human health or the environment when improperly treated, stored, transported, disposed of, or handled.

\section{Internal radiation}

Radiation from a source within the body as a result of deposition of radionuclides in body tissues by processes such as ingestion, inhalation, or implantation. Potassium $(40 \mathrm{~K})$, a naturally occurring radionuclide, is a major source of internal radiation in living organisms.

\section{Millirem}

A common unit for reporting radiation dose. A millirem is one thousandth $\left(10^{-3}\right)$ of a rem. See Rem.

\section{Nuclide}

A species of atom characterized by what constitutes the nucleus, which is specified by the number of protons, number of neutrons, and energy content; or, alternatively, by the atomic number, mass number, and atomic mass. To be regarded as a distinct nuclide, the atom must be able to exist for a measurable length of time.

\section{Organic compound}

A chemical whose primary constituents are carbon and hydrogen.

\section{Part B permit}

The second, narrative section submitted by generators in the RCRA permitting process. It details the procedures followed at a facility to protect human health and the environment.

\section{Person-rem}

The unit of population dose, which expresses the sum of radiation exposures received by a population. For example, two persons, each with a 0.5 -rem exposure, receive 1 person-rem, and 500 people, each with an exposure of $0.002 \mathrm{rem}$, also receive 1 person-rem.

\section{pH}

A measure of hydrogen ion concentration in an aqueous solution. Acidic solutions have a $\mathrm{pH}$ less than 7 , basic solutions have a $\mathrm{pH}$ greater than 7 , and neutral solutions have a $\mathrm{pH}$ of 7 .

\section{Piezometer}

Generally, a small-diameter, nonpumping well used to measure the elevation of the water table or potentiometric surface. The water table is an imaginary surface that represents the static head of groundwater and is defined by the level to which water will rise.

\section{Pollutant}

Any hazardous or radioactive material present in an environmental medium such as air, water, or vegetation.

\section{Pretreatment}

Any process used to reduce a pollutant load before wastewater enters the sewer system.

\section{Priority pollutants}

A set of organic and inorganic chemicals identified by US/EPA as indicators of environmental contamination 


\section{Rad}

A unit of absorbed dose from ionizing radiation ( $0.877 \mathrm{rad} /$ roentgen).

\section{Radiation protection standard}

Limits on radiation exposure regarded as necessary for protection of public health. These standards are based on acceptable levels of risk to individuals.

\section{Radiation}

Energy emitted from the nucleus of an atom in the form of waves or particles.

\section{Radioactivity}

The property or characteristic of a nucleus of an atom to spontaneously disintegrate, accompanied by the emission of energy in the form of radiation.

\section{Radiological}

Arising from radiation or radioactive materials.

\section{Radionuclide}

An unstable nuclide. See nuclide and radioactivity.

\section{Recharge zone}

An area of the ground in which surface water migrates to the groundwater.

\section{Rem}

Stands for "roentgen equivalent man." A unit of ionizing radiation, equal to the amount of radiation needed to produce the same biological effect to humans as $1 \mathrm{rad}$ of high-voltage $\mathrm{x}$-rays. It is the product of the absorbed dose, quality factor, distribution factor, and other necessary modifying factors. It describes the effectiveness of various types of radiation in producing biological effects.

\section{Remediation}

See Environmental remediation.

\section{Roentgen}

A unit of radiation exposure that expresses exposure in terms of the amount of ionization produced by $\mathrm{x}$ or gamma rays in a volume of air. One roentgen is $2.58 \times 10^{4}$ coulombs per kilogram of air.

\section{Sievert}

A unit of radiation dose equivalent. The sievert is the SI unit equivalent to the rem. It is the product of the absorbed dose, quality factor, distribution factor, and other necessary modifying factors. It describes the effectiveness of various types of radiation to produce biological effects. One sievert equals 100 rem.

\section{Source}

Any operation or equipment that produces, discharges, and/or emits pollutants (e.g., pipe, ditch, well, or stack).

\section{Terrestrial}

Pertaining to or deriving from the earth.

\section{Terrestrial radiation}

Radiation emitted by naturally occurring radionuclides, such as $40 \mathrm{~K}$; the natural decay chains $235 \mathrm{U},{ }^{233} \mathrm{U}$, or ${ }^{232} \mathrm{Th}$; or cosmic-ray induced radionuclides in the soil.

\section{Thermoluminescent dosimeter}

A type of dosimeter. After being exposed to radiation, the material in the 
dosimeter (lithium fluoride) luminesces on being heated. The amount of light that the material emits is proportional to the amount of radiation (dose) to which it was exposed. See also Dosimeter.

\section{Tritium}

A radionuclide of hydrogen with a half-life of 12.3 years. The very low energy of its radioactivity decay makes it one of the least hazardous radionuclides.

\section{Uncontrolled area}

An area beyond the boundaries of a controlled area. See Controlled area.

\section{Upgradient}

Opposite of the direction of groundwater flow from a designated area of interest. Analogous to "upstream."

\section{Vadose zone}

The partially saturated or unsaturated region of the ground above the water table that does not yield water to wells.

\section{Wind rose}

A graph that shows the frequency and intensity of wind from different directions at a particular site.

Table G-1 Prefixes Used with SI (Metric) Units

\begin{tabular}{lll}
\hline Prefix & Factor & Symbol \\
\hline exa & $1,000,000,000,000,000,000=10^{18}$ & $\mathrm{E}$ \\
peta & $1,000,000,000,000,000=10^{15}$ & $\mathrm{P}$ \\
tera & $1,000,000,000,000=10^{12}$ & $\mathrm{~T}$ \\
giga & $1,000,000,000=10^{9}$ & $\mathrm{G}$ \\
mega & $1,000,000=10^{6}$ & $\mathrm{M}$ \\
kilo & $1,000=10^{3}$ & $\mathrm{k}$ \\
hecto & $100=10^{2}$ & $\mathrm{~h}^{*}$ \\
deka & $10=10^{1}$ & $\mathrm{da}^{*}$ \\
deci & $0.1=10^{-1}$ & $\mathrm{~d}^{*}$ \\
centi & $0.01=10^{-2}$ & $\mathrm{C}^{*}$ \\
milli & $0.001=10^{-3}$ & $\mathrm{~m}$ \\
micro & $0.000001=10^{-6}$ & $\mu$ \\
nano & $0.000000001=10^{-9}$ & $\mathrm{n}$ \\
pico & $0.000000000001=10^{-12}$ & $\mathrm{p}$ \\
femto & $0.000000000000001=10^{-15}$ & $\mathrm{f}$ \\
atto & $0.000000000000000001=10^{-18}$ & $\mathrm{a}$ \\
\hline
\end{tabular}

*Avoid where practical. 
Table G-2 Conversion Factors for Selected SI (Metric) Units

\begin{tabular}{|c|c|c|}
\hline To convert SI unit & To U.S. conventional unit & Multiply by \\
\hline \multicolumn{3}{|l|}{ Area } \\
\hline square centimeters & square inches & 0.155 \\
\hline square meters & square feet & 10.764 \\
\hline square kilometers & square miles & 0.3861 \\
\hline hectares & acres & 2.471 \\
\hline \multicolumn{3}{|l|}{ Concentration } \\
\hline micrograms per gram & parts per million & 1 \\
\hline milligrams per liter & parts per million & 1 \\
\hline \multicolumn{3}{|l|}{ Length } \\
\hline centimeters & inches & 0.3937 \\
\hline meters & feet & 3.281 \\
\hline kilometers & miles & 0.6214 \\
\hline \multicolumn{3}{|l|}{ Mass } \\
\hline grams & ounces & 0.03527 \\
\hline kilograms & pounds & 2.2046 \\
\hline kilograms & ton & 0.00110 \\
\hline \multicolumn{3}{|l|}{ Pressure } \\
\hline pounds per square foot & pascal & 0.000145 \\
\hline \multicolumn{3}{|l|}{ Radiation } \\
\hline becquerel & curie & $2.7 \times 10^{-11}$ \\
\hline gray & $\mathrm{rad}$ & 100 \\
\hline sievert & rem & 100 \\
\hline coulomb per kilogram & roentgen & 3,876 \\
\hline \multicolumn{3}{|l|}{ Temperature } \\
\hline degrees Celsius & degrees Fahrenheit & 1.8, then add 32 \\
\hline \multicolumn{3}{|l|}{ Velocity } \\
\hline meters per second & miles per hour & 2.237 \\
\hline \multicolumn{3}{|l|}{ Volume } \\
\hline cubic meters & cubic feet & 35.315 \\
\hline liters & gallons & 0.2642 \\
\hline
\end{tabular}




\title{
Internal Distribution
}

Community Relations

Ron Kolb

Terry Powell

Directorate

Reid Edwards

EH\&S Division

\author{
Jeffrey Chung \\ Iraj Javendal \\ Ginny Lackner \\ David McGraw \\ Ron Pauer \\ Gary Zeman \\ Michael Ruggieri \\ Patrick Thorson \\ Henry Tran \\ Robin Wendt \\ Otis Wong \\ Facilities Department \\ Robert Camper \\ Operations \\ Klaus Berkner \\ Laboratory Counsel \\ Nancy Shepard \\ Laboratory Library \\ Building 50 \\ Building 90P \\ National Tritium Labeling Facility \\ Philip Williams \\ Planning and Communications \\ Michael Chartock \\ Radiation Safety Committee \\ Henry VanBrocklin \\ 88-Inch Cyclotron \\ Claude Lyneis
}




\section{External Distribution}

Argonne National Laboratory

Robert Wynveen

Environment, Safety, and Health

9700 South Cass Avenue

Mailstop Building 201

Argonne, Illinois 60439-4802

Argonne National Laboratory (West)

Gary Marshall

Environment, Safety, and Health

P.O. Box 2528

Mailstop 6000

Idaho Falls, Idaho 83403-2528

Alameda County

Ariu Levi

1131 Harbor Bay Parkway

Alameda, California 94502

Association of Bay Area Governments

Terry Bursztynsky

P.O. Box 2050

Oakland, California 94604-2050

Bay Area Air Quality Management District

Ellen Garvey

939 Ellis Street

San Francisco, California 94109

Brookhaven National Laboratory

William Casey

Environment and Safety Protection

Building 535A

P.O. Box 5000

Upton, New York 11973-5000

California Air Resources Board

Jim Morgester

Compliance Division

P.O. Box 2815

Sacramento, California 95812 
California Department of Health Services

Ed Bailey

Environmental Management Branch

P.O. Box 942732

Mailstop 178

Sacramento, California 94234-7320

California Department of Health Services

Steve Hsu

Environmental Management Branch

P.O. Box 942732

Mailstop 178

Sacramento, California 94234-7320

California Department of Health Services

Gerard Wong

Radiological Health Branch

P.O. Box 942732

Mailstop 178

Sacramento, California 94234-7320

California Department of Health Services

William Lew

Radiological Health Branch

2151 Berkeley Way, Annex Z

Berkeley, California 94704

California Department of Toxic Substances Control

Salvatore Cirello

Facility Permitting Branch

700 Heinz Avenue, Suite 200

Berkeley, California 94710

California Regional Water Quality Control Board, San Francisco Bay Region Keith Lichton

1515 Clay Street, Suite 1400

Oakland, California 94612

California Regional Water Quality Control Board, San Francisco Bay Region Tom Mumley

Watershed Management Division

1515 Clay Street, Suite 1400

Oakland, California 94612 
California Regional Water Quality Control Board, San Francisco Bay Region

Michael Rochette

1515 Clay Street, Suite 1400

Oakland, California 94612

California State Water Resources Control Board

Heidi Temko

Clean Water Programs Division

2014 T Street, Suite 130

P.O. Box 944212

Sacramento, California 94244-2120

City of Berkeley

James Keene

City Manager

Civic Center Building

2180 Milvia Street

Berkeley, California 94704

City of Berkeley

Nabil Al-Hadithy

Office of Emergency and Toxics Management

Civic Center Building

2180 Milvia Street

Berkeley, California 94704

City of Oakland

Leroy Griffin

475 14th Street

Oakland, California, 94612

Community Environmental Advisory Commission

John Selawsky, Chair

1912 Blake Street

Berkeley, California 94704

East Bay Municipal Utility District

Mirtha Ninayahuar

Source Control Division

P.O. Box 24055

Oakland, California 94612-1055 
Fermi National Accelerator Laboratory Bill Griffing

Environment, Safety, and Health Section

P.O. Box 500

Mailstop 119

Batavia, Illinois 60510

Idaho National Engineering Laboratory George Ellis

Environmental Operations

P.O. Box 1625

Mailstop 3940

Idaho Falls, Idaho 83415-3898

Lawrence Livermore National Laboratory

Kris Surano

Environment, Health, \& Safety

P.O. Box 808

Mailstop L-629

Livermore, California 94551

Los Alamos National Laboratory

Dennis Erickson

Environment, Health, and Safety Division

P.O. Box 1663

Mailstop K491

Los Alamos, New Mexico 87545

National Renewable Energy Laboratory

Randy McConnell

Environment, Safety, and Health 1617 Cole Blvd.

Golden, Colorado 80401

Oakland Main Library

12514 th Street

Oakland, California 94612

Oak Ridge National Laboratory

Jerry Swanks

Operations, Environment, Safety, and Health

P.O. Box 2008

Mailstop 6260

Oak Ridge, Tennessee 37831-6260 
Pacific Northwest Laboratory

Kenneth Brog

Environment, Safety, and Health

P.O. Box 999

Mailstop P7-79

Richland, Washington 99352

\author{
Sandia National Laboratories, Albuquerque \\ Lynn Jones \\ Environment, Safety and Health \\ Laboratory Services \\ Sandia National Laboratories \\ P.O. Box 5800 \\ Mailstop 0361 \\ Albuquerque, New Mexico 87185-0361
}

Sandia National Laboratories, California

Robert Holland

Environmental Protection Division

P.O. Box 969

Mailstop 9221

Livermore, California 94551-9221

Savannah River Plant

Dennis Stevenson

Environmental Monitoring

Health Protection Department

Building 735A

Aiken, South Carolina 29808

Stanford Linear Accelerator Center

Michael Grissom

Environmental Safety and Health Division

2575 Sand Hill Road

Mailstop 84

Menlo Park, CA 94025-7015

University of California, Office of the President

Howard Hatayama

300 Lakeside Drive, 7th Floor

Oakland, California 94612-3550 
University of California at Berkeley Main Library (Doe)

Berkeley, California 94720

University of California at Berkeley

Susan Spencer

Environment, Health and Safety

University Hall, 3rd Floor

Berkeley, California 94720

University of California at Berkeley

Paul Laveley, Director

Office of Radiation Safety

359 University Hall

Berkeley, California 94720

University of California at San Francisco

Environment, Health, and Safety

Ara Tahmassian

50 Medical Center Way

San Francisco, California 94143

University of California at Berkeley

Lawrence Hall of Science, \#5200

Barbara Ando

Berkeley, California 94720-5200

U.S. Department of Energy

Richard Nolan, Director

Berkeley Site Office

Lawrence Berkeley Laboratory

Mail Stop 90-1020

Berkeley, California 94720

U.S. Department of Energy

Headquarters (ER-80), Forrestal

Caryle Miller

1000 Independence Avenue SW

Mailstop 3F-077/FORS

Washington D.C. 20585 
U.S. Department of Energy

Office of Scientific and Technical Information

P.O. Box 62

Oak Ridge, Tennessee 37831

U.S. Environmental Protection Agency

Region 9

Shelly Rosenblum

Air and Toxics Division

75 Hawthorne Street

San Francisco, California 94105 